\title{
INFECTIOUS INEQUALITIES
}

\author{
EPIDEMICS, TRUST, \\ AND SOCIAL VULNERABILITIES IN CINEMA
}

Qijun Han and Daniel R. Curtis 


\section{Infectious Inequalities}

This book explores societal vulnerabilities highlighted within cinema and develops an interpretive framework for understanding the depiction of societal responses to epidemic disease outbreaks across cinematic history.

Drawing on a large database of twentieth- and twenty-first-century films depicting epidemics, the study looks into issues including trust, distrust, and mistrust; different epidemic experiences down the lines of expertise, gender, and wealth; and the difficulties in visualizing the invisible pathogen on screen. The authors argue that epidemics have long been presented in cinema as forming a point of cohesion for the communities portrayed, as individuals and groups "from below" represented as characters in these films find solidarity in battling a common enemy of elite institutions and authority figures. Throughout the book, a central question is also posed: "cohesion for whom?", which sheds light on the fortunes of those characters that are excluded from these expressions of collective solidarity.

This book is a valuable reference for scholars and students of film studies and visual studies as well as academic and general readers interested in topics of films and history, and disease and society.

Qijun Han is Associate Professor at the School of Foreign Studies, Nanjing University of Science and Technology (China). She has published widely in film, media, and cultural studies in journals such as Cultural and Social History; Historical Journal of Film, Radio and Television; Critical Arts; Continuum; Gender and History; Visual Studies; and many more.

Daniel R. Curtis is Associate Professor at the Erasmus School of History, Culture and Communication, Erasmus University Rotterdam (The Netherlands). He has published widely in social and environmental history in journals such as Economic History Review; Speculum; Journal of Social History; Environment and History; American Journal of Physical Anthropology; Journal of Interdisciplinary History; Medical Humanities; and many more. 


\section{China Perspectives}

The China Perspectives series focuses on translating and publishing works by leading Chinese scholars, writing about both global topics and China-related themes. It covers Humanities \& Social Sciences, Education, Media and Psychology, as well as many interdisciplinary themes.

This is the first time any of these books have been published in English for international readers. The series aims to put forward a Chinese perspective, give insights into cutting-edge academic thinking in China, and inspire researchers globally.

To submit proposals, please contact the Taylor \& Francis Publisher for the China Publishing Programme, Lian Sun (Lian.Sun@informa.com)

Titles in media communication currently include:

Communication and Community in the New Media Age Wang Bin

Cultural Expression and Subjectivity of Chinese Peasants

Sha Yao

The Nanjing Massacre and the Making of Mediated Trauma

Hongtao Li and Shunming Huang

Environmental Risk Communication in China

Actors, Issues and Governance

Jia Dai, Fanxu Zeng

Infectious Inequalities

Epidemics, Trust, and Social Vulnerabilities in Cinema

Qijun Han and Daniel R. Curtis

For more information, please visit: www.routledge.com/China-Perspectives/ book-series/CPH 


\section{Infectious Inequalities}

Epidemics, Trust, and Social Vulnerabilities in Cinema

\section{Qijun Han and Daniel R. Curtis}


This book is funded by the Netherlands Organisation for Scientific Research (NWO): a VIDI (grant no. 016.Vidi.185.046), which provided the funds for open access status. It is also funded by the Chinese National Ministry of Education, Humanities and Social Science (grant no. 16YJC760013); the Fundamental Research Funds for the Central Universities (grant no. 30919013302); and the Jiangsu Overseas Visiting Scholar Program for University Prominent Young and Middle-aged Teachers and Presidents, China.

First published in English 2022

by Routledge

2 Park Square, Milton Park, Abingdon, Oxon OX14 4RN

and by Routledge

605 Third Avenue, New York, NY 10158

Routledge is an imprint of the Taylor \& Francis Group, an informa business

(C) 2022 Qijun Han and Daniel R. Curtis

The right of Qijun Han and Daniel R. Curtis to be identified as authors of this work has been asserted in accordance with sections 77 and 78 of the Copyright, Designs and Patents Act 1988.

The Open Access version of this book, available at www.taylorfrancis. com, has been made available under a Creative Commons Attribution-Non Commercial-No Derivatives 4.0 license.

Trademark notice: Product or corporate names may be trademarks or registered trademarks, and are used only for identification and explanation without intent to infringe.

British Library Cataloguing-in-Publication Data

A catalogue record for this book is available from the British Library

Library of Congress Cataloging-in-Publication Data

Names: Qijun, Han, 1981- author. | Curtis, Daniel R., 1985- author.

Title: Infectious inequalities : epidemics, trust, and social vulnerabilities in cinema / Qijun Han and Daniel R. Curtis.

Description: Abingdon, Oxon ; New York : Routledge, 2022.

Identifiers: LCCN 2021042990 (print) | LCCN 2021042991 (ebook) | ISBN 9781032199665 (hardback) | ISBN 9781032205205 (paperback) | ISBN 9781003261667 (ebook)

Subjects: LCSH: Epidemics in motion pictures. | Motion picturesHistory-20th century. | Motion pictures-History-21st century. |

Motion pictures-Social aspects.

Classification: LCC PN1995.9.E793 Q55 2022 (print) | LCC PN1995.9.

E793 (ebook) | DDC 791.43/61—dc23/eng/20211019

LC record available at https://lccn.loc.gov/2021042990

LC ebook record available at https://lccn.loc.gov/2021042991

ISBN: 978-1-032-19966-5 (hbk)

ISBN: 978-1-032-20520-5 (pbk)

ISBN: 978-1-003-26166-7 (ebk)

DOI: $10.4324 / 9781003261667$

Typeset in Times New Roman

by Apex CoVantage, LLC 
To our parents

致我们的父母 


\section{Contents}

List of figures viii

Acknowledgments ix

1 Understanding epidemics through the cinematic lens 1

2 Societal responses to epidemics: immorality and resistance 27

3 Suspicious minds: cinematic depiction of distrust during epidemics

4 Bridging the gap: epidemics, public health workers, and "heroism" in cinematic perspective

5 From spreaders to sacrifice: cinematic representation of women during epidemics

6 Between urban depravity and rural backwardness: cinematic depiction of poverty during epidemics

Conclusion: epidemics and cinema in an age of COVID-19 Index 


\section{Figures}

1.1 Hoard of toilet paper in 洞 [Dong/The Hole] (Tsai Ming-liang, 1998)

1.2 The "hidden enemy" in Diseases Spread (Sanae Yamamoto, 1926) 3

1.3 Temporal distribution of films in the film database 13

1.4 "Doc" dealing with the water reeds in The Winged Scourge (Bill Justice, 1943) 15

1.5 "Rats" in Nosferatu: Phantom der Nacht (Werner Herzog, 1979) 17

2.1 Playing chess with "Death" in Det sjunde inseglet (Ingmar Bergman, 1957)

2.2 The paranoid mob in Le Hussard sur le toit (Jean-Paul Rappeneau, 1995) 38

4.1 Death of Dr. Erin Mears in Contagion (Steven Soderbergh, 2011) 73

4.2 Village discontent at the water well in The Painted Veil (John Curran, 2006) 74

4.3 Anger at the burial grounds in The Painted Veil (John Curran, 2006) 74

4.4 "Sisterhood" in Blindness (Fernando Meirelles, 2008) 80

5.1 Representation of Mary Mallon, The New York American, 20 June 1909

5.2 "Marit, the spreader" in Himlaspelet (Alf Sjöberg, 1942) 89

5.3 "Burning Marit" in Himlaspelet (Alf Sjöberg, 1942) 89

5.4 The woman's "carelessness" in Diseases Spread (Sanae Yamamoto, 1926) 91

5.5 "Noffie the Skita" in Borne on Two Wings (UK War Office, 1945) 91

5.6 "The red dress" in Jezebel (William Wyler, 1938) 99

6.1 "Raiding the bakeries" in I promessi sposi (Mario Bonnard, 1923) 117

6.2 "The plagued soldier" in I promessi sposi (Mario Bonnard, 1923) 118

6.3 Female "barefoot doctor" stamp, 1974

6.4 "Noodle for one" in 洞 [Dong/The Hole $]$ (Tsai Ming-liang, 1998) 123

6.5 "Grace Chang scene 1" in 洞 [Dong/The Hole] (Tsai Ming-liang, 1998)

6.6 “Grace Chang scene 2" in 洞 [Dong/The Hole] (Tsai Mingliang, 1998)

6.7 Original poster for The Painted Veil (Richard Boleslawski, 1934) 126 


\section{Acknowledgments}

This book brings together one author with historically grounded expertise in societal responses to epidemics and one author with expertise across various fields of film and cultural studies. What links us is our focus on both the experiences and the representation of the vulnerable or marginalized within different social and historical contexts. Although the book is concerned with the cinematic representation and depiction of societal responses to epidemic disease outbreaks across the long term, the reader will soon note that this is not a traditional approach to "film studies". The theoretical or analytical point of departure is not driven by "film studies questions", and our method departs from "film studies approaches" that often take a limited selection of films and analyze them in depth down various lines. Instead, we have collected a large database of films depicting epidemics to observe patterns and trends over time and across geographical areas, and accordingly, we are interested in understanding and analyzing generalities in cinematic visualization and presentation of the epidemic-society interaction-not particularized contextual details about one or two illuminating films.

The major theoretical path forward in this book is a shift away from top-down approaches to society-epidemic interactions - where emphasis tends to be on the imposition of social controls from elites or authorities - to the reception of these attempted social controls from below, and how this dynamic has been represented in one of the most important areas of visual culture in the twentieth- and twentyfirst centuries. Overall, we believe that epidemics often bring into view social vulnerabilities hidden from view in "normal" times - even in societies where institutions, infrastructures, and systems display forms of resilience-and we believe that films are a useful tool for foregrounding this process. Of course, films are not reality, and we do not see them as mere extensions of social truths. But it is clear that there is a twin association between the two-films are sometimes based on reality, providing illustrations via implicit meanings and reflecting societal attitudes and assumptions, and reality is often shaped by the narratives and images that we hear and see. Stories are, after all, how many of us make sense of the world. The extent to which one drives the other likely cannot be quantified or even measured with precision. But it is instructive to recognize that research done in the broad fields of science communication and public understanding of science have been emphasizing the educational role of popular culture for public health outcomes through a variety of different interdisciplinary methods. 


\section{x Acknowledgments}

The research for this book has been made possible through the support of a VIDI project on epidemics, redistribution, and social vulnerability funded by the NWO, and carried out at the Erasmus School for History, Culture and Communication (grant no. 016.Vidi.185.046). Moreover, the funds to make the book open access were acquired via this same NWO grant. Funding has also been received from the Chinese National Ministry of Education with a Humanities and Social Science grant (no. 16YJC760013), the Fundamental Research Funds for the Central Universities (grant no. 30919013302), and the Jiangsu Overseas Visiting Scholar Program for University Prominent Young Teachers and Presidents, China. We thank Daniëlle de Kurver and Madelon Harmsen of Erasmus University Rotterdam for their efforts as research interns, reading through and checking the manuscript, searching for images, and providing notes on relevant lines of argumentation.

Some of the chapters in this book have been updated and adapted from open access journal articles under Creative Commons 4.0 licenses. A version of Chapter 3 has appeared in BMJ: Medical Humanities (see https://mh.bmj.com/con tent/47/2/248), and Chapter 4 has been significantly adapted from an article in Visual Studies (see www.tandfonline.com/doi/full/10.1080/1472586X.2021.1907781). 


\section{Understanding epidemics through the cinematic lens}

As the world struggles to deal with the demands of COVID-19, a frequent remark often made during these times has been that living the experience is "like being in a film"- possibly in dual reference to the vast geographic scale and extraordinary economic and cultural impact on societies. Militarized rhetoric on combatting the "invisible enemy" - as in times of war-has taken off, while previously venerated institutions such as the Centers for Disease Control and Prevention (CDC) and the World Health Organization (WHO) have been the subject of direct criticism and distrust. Lockdowns of entire communities, the omnipresence of figures walking around in hazmat suits, empty aisles in supermarkets, curfews, riots, and protests are just some of the images that we would previously have ascribed to the big screen rather than real life. Indeed, although the notion of the hoarding of toilet paper seemed puzzling and beyond comprehension in the initial phases of the outbreak, films such as the celebrated Taiwanese classic 洞 [Dong/The Hole] (Tsai Ming-liang, 1998) had already had visualized that very same scenario with the thousands of rolls kept in the apartment by the "woman downstairs" (Yang Kuei-Mei), as seen in Figure 1.1.1 In some cases, individual events have almost seemed too implausible even to be part of a film plot. Heads of governments in wealthy democracies have casually dismissed the disease as nothing more than "common flu", proudly and openly declared to have shaken hands with those infected, and suggested internal consumption of disinfectants.

Ultimately, it remains to be seen whether or not COVID-19 will lead to deep structural changes within our societies, either cultural or institutional, but it is, at the very least, bringing to the foreground various concerns about how we have been living our lives - the effects of globalization, human environmental and ecological footprints, and various forms of inequality down the lines of age, gender, ethnicity, race, health and disability, and socio-economic status (Curtis and van Besouw, 2020; Hilkens et al., 2020; Green, 2020b). Although prior to this global pandemic there was a prominent narrative that epidemics throughout history have acted as a form of "great leveler" - redistributing wealth, resources, and opportunity more equally (Scheidel, 2017) - COVID-19 has clearly picked apart these pre-existing inequalities, at least in the short term, magnifying social vulnerabilities further.

DOI: $10.4324 / 9781003261667-1$ 


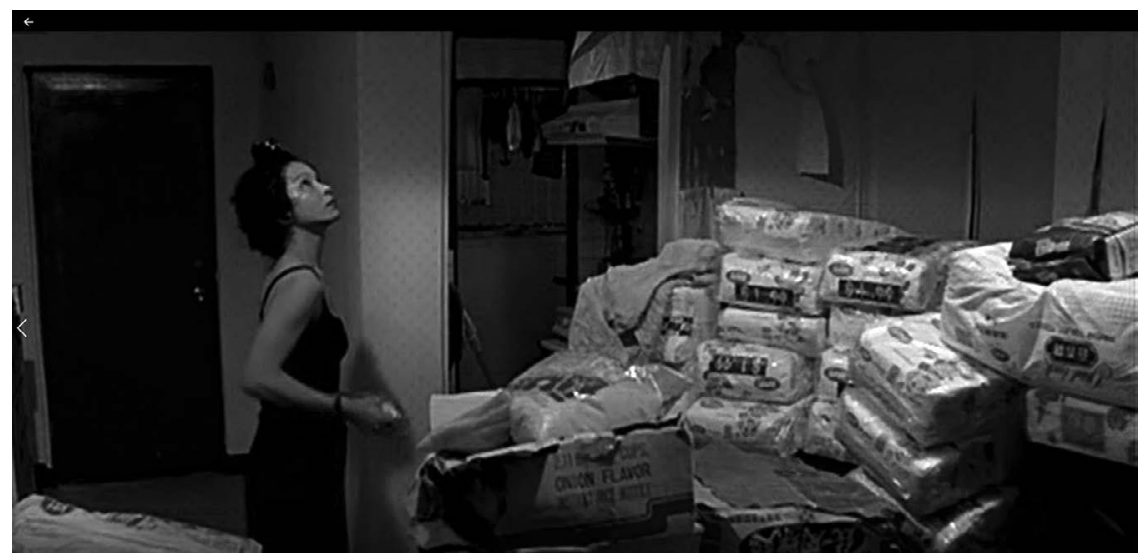

Figure 1.1 Hoard of toilet paper in 洞 [Dong/The Hole] (Tsai Ming-liang, 1998)

Source: Captured from personal copy.

In this book, by drawing upon and analyzing a large corpus of films produced across the twentieth- and twenty-first centuries that depict epidemic disease outbreaks (see filmography), we inquire into what the view from cinematic history has been on this topic - mainly, though certainly not exclusively, drawing upon examples from North America, Europe, and East Asia. Overall, this book makes a clear three-pronged argument. We argue that, first, cinema has tended to visualize two very particular societal responses to epidemics - one that revolves around a breakdown in sociability and cohesion through concerns over perceived immorality, and one that revolves around a community's preservation of tightly held social norms and customs. Second, we argue that the nature of these depicted societal responses in film often has its roots in different forms of distrust formed between characters and institutions at a variety of different levels. Third, we argue that this distrust frequently has little do with the characters' fear of the pathogen or disease itself - it does not appear out of nowhere- but is born out of pre-existing entrenched social inequalities, which are amply brought into view through the film narrative, character development, and production techniques.

Accordingly, we put forward an interpretive framework for films depicting epidemics in which socially differentiated vulnerability is at the core (van Bavel et al., 2020). Epidemics form a point of cohesion for communities, as people and groups from below in these films find solidarity in a common enemy comprising of elite (sometimes expert) and authority figures and institutions. However, despite this communal solidarity, certain social groups and individuals are marginalized as the Other- kept separate and not included in the diverse forms of collective action. They are disconnected and "dispossessed within these imagined communities" (Pokornowski, 2013: 216). Furthermore, many of the figures in these films - such as medics with expertise - appear on the blurred boundaries of 
cohesion and marginalization: part revered as heroes, part unrecognized, or even despised as elites or outsider meddlers that are simply unreceptive to local cultural contexts and practices.

We suggest that this kind of framework is supported in cinema through the many complications in screening disease-either as the invisible and unseen microbe, or as the visually unappealing symptoms - which become repackaged and pushed to a safe distance (perhaps an acceptable "social distance" in line with recent COVID-19 terminology) for audiences to appropriately consume and digest (Jacobsen, 2016: 10). From the earliest films of the twentieth century presenting epidemics as "cultural commodities" (Lederer, 2007: 96; Tomes, 2002), directors and animators attempted to visualize the microbe or some sort of sentient "creature" spreading the microbe- often as an unsavory or malevolent character-as seen, for example, in the Japanese short animation from 1926, 病毒の 伝播 [Byodoku no denpa/Diseases Spread], seen in Figure 1.2. The same sinister pathogen - associated with racist imagery of primitive cultures and primordial threats - has remained to this day with the visualization of COVID-19 (Ostherr, 2020). Accordingly, any negative or unwanted characteristics eventually become physically or culturally transplanted onto targeted groups of people instead (or as well) - marked down lines of race, class, gender, and sexuality (Ostherr, 2002: 1) - and particularly when these afflictions are seen to threaten the cohesion of the social bond, where carriers rather than the pathogen itself are suppressed (Weinstock, 1997: 84). Indeed, films provide the visual raw materials that make the invisible visible by linking the unseen germ to broader narratives and concerns about societal change (Tomes, 2000; Mullens, 2004). The indiscriminate (and

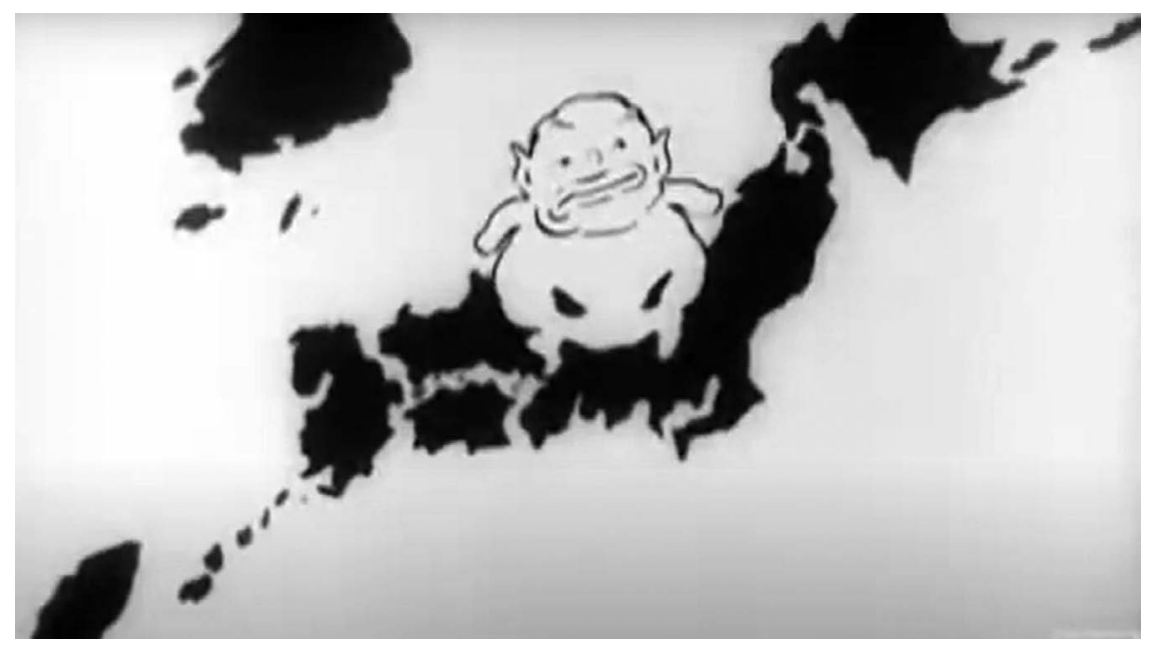

Figure 1.2 The "hidden enemy" in Diseases Spread (Sanae Yamamoto, 1926)

Source: Captured from the original film accessible at https://animation.filmarchives.jp/en/works/ playen/5433. 
inaccurate) categorization of all diseases as "plagues" (an inherently moralizing term: Williams, 2017: 198) often seen in cinema is testament to this personification of social decay or instability (Healy, 2001: 61-63), and frequently is demonstrated in the fear of increased human proximity to the infectious undead such as the zombie and their representation of bodily corruption (Cooke, 2009: 14; Paffenroth, 2011). The fact that these techniques for making the invisible visible have continued even with the representation of COVID-19-reinforcing prejudicial narratives about containment and control (Ostherr, 2020) — suggests that these recurring elements from cinematic history are deeply entrenched within the psychology of modern societies.

\section{Reinforcing messages and entrenching values}

Why have we decided to analyze the connections between trust, inequality, and vulnerability through the lens of cinema? Film has instilled in successive generations a fear of the microbe (Tomes, 2010: 61), and obviously COVID19 has drawn heightened attention and interest in epidemics-related films. In March 2020, Contagion (Steven Soderbergh, 2011) became one of the top mostdownloaded movies on iTunes around the world (Dehority, 2020). However, even prior to the global pandemic, films such as 战狼2 [Zhan lang II/Wolf Warrior 2] (Wu Jing, 2017) - a Chinese film dealing with a fictional outbreak of "Lamanla" (loosely based on Ebola) in (an undetermined region of) Africa-had grossed almost one billion dollars at the box office (more than six times that of Contagion), which is testament to the genre's contemporary popularity across a diversity of cultural contexts. "Pandemic movies" have become almost a genre unto themselves (Slugan, 2021), with increased circulation of terms such as "virus", "infection", "contagion", "quarantine" in film databases such as IMDb. Perhaps in response to this, the term pandemic has even made its way into the description of films on Netflix where no form of epidemic disease outbreak even occurs in the plot-see, for example, the description of Moartea domnului Lăzărescu (Cristi Puiu, 2005), winner of the Un Certain Regard award at Cannes, where the Romanian hospitals' overcapacity is caused by structural institutional problems and a bus crash, rather than disease patients. ${ }^{2}$ COVID-19 has also affectedpotentially in a long-term structural way-how films are going to be accessed and consumed by viewers in the future, as the forced cessation of business for cinemas has accentuated a pre-pandemic trend towards increased production for the "small screen".

However, much more essential than all this, it has been shown that films - and visual culture more generally_affect how we think and feel. Stories are how we make sense of the world and how we share that understanding with othersin psychology, described as "symbolic sense-making processes" (Wagner et al., 2002). They also embody cultural values and morals and reflect civilizational assumptions (Bergesen, 2016: 585). Indeed, according to Gustave Le Bon in The Crowd, "the epidemic of influenza [of 1889-1890 in Paris] . . made very little impression on the popular imagination" with the reason being that the disease was 
"not embodied in the visual image, but was only learnt from statistical information furnished weekly" (Davis, 2013: 137). Accordingly, it has been suggested that by using emotive narratives or relatable and engaging characters, together with visual images, films can become effective mediums for delivering messages or reinforcing and entrenching values, and in the context of epidemic diseases, have implications for how viewers might think about how to act and behave either during, after, or in anticipation of an outbreak (Wald, 2008; Ostherr, 2005, 2002; Kendal, 2021; Han and Curtis, 2020). ${ }^{3}$ Epidemics represented on screen help us understand concepts such as contagion and immunity and their possible ramifications, and thus inform our individual and collective views on potential implied threat to life (Davis and Lohm, 2020: 1). Thus, for example, it has been recently argued that decidedly pro-vaccination sentiments - a form of "persuasion narrative"-in films such as Contagion might actually have had a detrimental impact on public health messaging with its overly optimistic outcomes (McGuire, 2021). Even highly implausible situations such as those seen in zombie infection movies are now said to have significant public health implications (Brown et al., 2015; Kruvand and Silver, 2013). Indeed, answers given by a sample of the public to a Twitter forum set up by the CDC in 2011 revealed the strong link between zombies and public health awareness-bringing into popular view issues connected to contagion, mental health, ethics of disease management, and vulnerability to bioterrorism (Nasiruddin et al., 2013: 812). Also, on the reverse side, media responses actually represented within films connected to zombie infections often emphasize the susceptibility of the public to be misled by these messages (Paffenroth, 2011).

Of course, if such messages can be so effectively disseminated to an audience, this can have significant social consequences - not least because the narratives presented offer opportunity for negotiation and contestation of meaning based on the social worlds and realities of the audiences (Ricoeur, 1981). This is of even greater relevance when we consider that today, especially in the age of social media and populist governments, societal trust in sources of information is very fragile, leading at times to mistrust. For example, it was noted in the context of the recent Ebola outbreaks in Western Africa that the media in various countries often served to perpetuate several misguided anxieties over how people can be infected and how the disease spreads (Millard, 2015; Blakey et al., 2015). Accordingly, much like news reporting and social media, other forms of popular culture such as fictional novels, comics, television shows, and films can also influence people's trust - trust in authorities, institutions, medical advice, experts, and other people (Han and Curtis, 2021d). This is especially the case if we consider that the information provided about an epidemic disease is sometimes seen by audiences as grounded in "scientific fact", even when that is not necessarily the intention of the producer, director, writer, artist, or creator (Foreman Jr., 1995; Pappas et al., 2003; Kendal, 2021; Doherty and Giordano, 2020). This issue is brought into view when we consider that it was recently observed that visual images of historical disease outbreaks were being incorrectly "diagnosed" as "plague"-from popular forums such as Wikipedia and tourist advertisements to authoritative "expert" 
forums such as encyclopedias, museum exhibitions, and world-renowned science journals - simply through replication of recurring error after error and lack of multidisciplinary expert review (King and Green, 2018; Jones and Nevell, 2016; Green et al., 2014).

As well as trust, distrust, and mistrust, the strength of these messages via popular culture can also help entrench prejudices and common stereotyping connected to concepts of othering. In one of the most influential theoretical frameworks for understanding the connection between epidemics, media, and society, Priscilla Wald's original work identified a form of recurring "outbreak narrative" often seen in popular culture, where a common series of visual motifs are used to plot the spread of an epidemic as moving in only one direction from what can be described as "marginalized", "deviant", or "underdeveloped" groups to "native", "mainstream", or "developed" society (2008). ${ }^{4}$ Indeed, it was this kind of narrative that informed the moral panic (on this concept: Gilman, 2010; Muzzatti, 2005) behind the potential spread of Ebola from parts of Western Africa to other parts of the world-becoming perhaps the "archetypal Emerging Infectious Disease (EID)" of our age (Herrick, 2019) — with a politics of fear that proved to be completely unfounded in this case (Hofman and $\mathrm{Au}, 2017$ ). Indeed, going further back in time to the mid-1990s, a headline from Newsweek on 22 May 1995 read: "We want to know whether Ebola is heading our way. Could it reach a critical mass in a Third World capital, then engulf the globe?" (King, 2015: 187). Such fears are sadly ironic in light of the current struggle with COVID-19, where the chain of vulnerability has been reversed. Poorer societies across Africa and the Middle East have been exposed in an initial movement of the contagion from more affluent areas of East Asia and Western Europe, and in the worst scenarios, may also have to deal with secondary vulnerabilities in the form of unstable or spiked food prices in the aftermath of a global economic contraction (as seen during the global financial crisis of 2008: Bohstedt, 2016), as well as inequitable access to vaccines and treatments.

As well as shining a light on different forms of prejudice and vulnerability connected to epidemic disease, film narratives - by way of fictional stories and characters - can also help bring to the surface traumatic stories that are difficult to discuss openly through real personal experiences as a result of stigma (Davis and Manderson, 2014) or have been lost as oral traditions of the marginalized (Fisher, 2012: 4-5). For a large portion of literary history, likely up to the midtwentieth century across many parts of the world, candid personal insights into sickness or illness were often considered too intimate for public sharing (Jurecic, 2012), or too sensitive. Indeed, this has been argued as one of the major reasons why we have very few personal illness narratives taken from the global influenza pandemic of 1918-1920 (Belling, 2009) - described as a particular "representational demand" of epidemic disease. The distressing and confusing side of that pandemic in turn led to neglect or repression of the difficulties in engaging with a painful topic (Fisher, 2012: 20), and it has been noted that most of the images we have from this outbreak of influenza emphasize preparedness rather than corpses and death (Budd, 2018: 157). Thus, although presented as a pandemic producing 
more "egalitarian" or "cohesive" societal responses grounded in solidarity (Cohn, 2018), it is also possible that the inequitable impact and differential vulnerabilities were simply obscured through this problem (Jones, 2006).

On a related note, films - and other visual culture - can be effective ways of negotiating difficult ethical questions about voyeurism and the exposure of suffering during diseases. Indeed, just like during military conflicts, there has been some debate about whether it is appropriate to visually document the individual struggle with COVID-19- the gray area between compassionate observation and indecent intrusion (Anon., 2020b). ${ }^{5}$ Fictionalized accounts, even if based on reality, help to address issues connected to epidemics which may be too distasteful to do based on the experiences of real sufferers that require dignity. There is likely a reason why in many countries we have had so few images of the exact events going on within the most burdened of hospitals - to do so would not only confront us with suffering, but also (in the context of the West, at least) racialized health disparities (Ostherr, 2020). When we return to the iconography of SARS in 2003, most images were based around an absence of sickness rather than its presence, where instead we were confronted with images of crowds wearing surgical masks and environments such as airports and hotels completely devoid of people (Serlin, 2010: xiv).

Films are especially effective mediums for providing insights into issues such as trust, inequality, and vulnerability during epidemics because they seamlessly shift between the macro scale of humanity or society to the micro scale of individual protagonists and relatable characters. By taking in a wide range of social and demographic groups, films can help shine new light on some of the mechanisms involved in societal responses to epidemic diseases, and more to the point, reveal how they are shaped by pre-existing conditions and structures within society itself - including hierarchical and horizontal relationships between people as active agents. Indeed, by developing individual characters and protagonists, we can zoom in on the lives of ordinary citizens - especially the poor and marginalized - who often get pushed into the background in favor of "macroscopic" elements of disease management in other types of media reporting (Horton, 2020). As remarked in a classic text from Siegfried Kracauer on the "theory of film":

Products of habit and microscopic interaction, they [everyday lives] form a resilient texture which changes slowly and survives wars, epidemics, earthquakes, and revolutions. Films tend to explore this texture of everyday life whose composition varies according to place, people, and time.

(1997: 304)

It should be added that films also integrate well the temporal dynamics of an epidemic disease outbreak - their episodic (termed as "episodemic" in Cooke, 2009: 24; see also the classic: Rosenberg, 1989) character of emergence, peak, and ebbing away, fitting with the three-act "Aristotelian" narrative arc of settling, disruption, and resolution (Davis and Lohm, 2020: 5). On the one hand, films may present epidemics as entirely new threats or challenges to a society (King, 2015: 
181-182), and yet perhaps paradoxically, this is founded upon repetitive use of recurring characters, symbols, and images that form, in Wald's terminology, an "outbreak narrative" comprising of an assortment of "heroes" and "villains" (Roy et al., 2020). Films, as well as depicting death, also focus on survivors, and thus can help us problematize and rethink "the end phases" of a pandemic or epidemic - perhaps reformulating paradigms of "containment" to new kinds of "epidemic scripts" (Kudlick, 2014). This is not necessarily a reflection upon "what is happening", but a visualization of "what could happen next" (Doherty and Giordano, 2020).

The fact that films are important vehicles through which messages, ideas, and values have been passed on to audiences about society-epidemic entanglements can be further demonstrated through recourse to the longer history of moving images. Popular culture and healthcare and medicine are constantly informing one another (Görgen et al., 2019: 2). In recent times, cinema has even been used to teach aspects of disease and healthcare to medical students (Darbyshire and Baker, 2012), perhaps seen as part of a broader trend in the "medialization of science" - the mutual relationship between the social systems of science and the mass media or popular culture (Weingart, 2012). Thus, for example, in Soderbergh's Contagion, many of the cast and crew members visited the CDC for preliminary research before filming, in the interests of developing "authenticity" (Kirby, 2014) - something which CDC officials at the time welcomed as a way of engaging the young in particular in public health issues (Anon., 2014a). One of the recent facets of this trend is the partnering of a number of scientific institutes with media and cultural organizations such as "Hollywood, Health \& Society" or the "Geena Davis Institute" to address issues regarding diversity of representation of public health personnel on screen down the lines of race and gender (Anon., 2017; Kirby, 2017: 11).

Nevertheless, it should be emphasized that films have long served as important sources of information, and therefore, educational tools for public health and disease control-providing different forms of representation from written and oral descriptions (Peckham, 2015), but also conveying societal interaction with microbes in a way that still visual culture such as photos, caricatures, pamphlets, and posters could not. Early documentary films, especially in the 1910s and 1920 s, can be plentifully found from different parts of the United States, Western Europe, and East Asia. Although the surface objective of these short films was to educate audiences about the dangers of practices that could lead to epidemic disease outbreaks - training viewers to recognize threatening situations (Ostherr, 2005: 2-7) - they also, perhaps understandably, came with moralized instructions centered on deviant or improper behavior (Stein, 2006: 16). American documentary films of the 1920s and 1930s warned audiences about the dangers of polio and tuberculosis - a threat to every home - and yet the "most dangerous homes" were those identified to be a feature of specifically black American culture. These were clear racialized discourses, which only later came to be challenged in the 1950s and 1960s (Mitman, 2010: 43-44). Thus, short educational dramas such as Let My People Live (Edgar G. Ulmer, 1938) focused specifically on tuberculosis 
in a black community bound together by the church-emphasizing the scourge of superstition and ignorance in contrast to "modern" medical instruction. In one scene we see the clear moralizing message from a doctor that a black man should protect his health by not using up all his energy "staying out late at night". In Prevention of the Introduction of Diseases from Abroad, part of a longer medical documentary from the United States Public Health service in 1936, it was iterated that the threat lay beyond the country's borders-emphasizing that diseases such as yellow fever had been banished from the United States since 1905, and yet were a "fact of life" in South America or Africa (King, 2015: 190). Meanwhile, in pre-Apartheid South Africa in the 1930s, educational films on epidemic disease were partially in response to rapid spread of tuberculosis and syphilis, but encouraged not by officials as a form of "paternalistic concern" for poor black communities, but out of fears from white groups at the "dangers" this posed (Jeeves, 2003: 111-112).

Elsewhere, the Korean Insaeng ŭi ku: hoyŏlja [Life's Enemy: Cholera] (Kim Sorang, 1920), for example, used cholera to create a moral narrative on two scales: a justification of "modernizing" practices connected to the colonial authority of Japan (diseases were associated with a feudal, and thus "backward", past), a feature also shared with similar films shown in Taiwan during the cholera outbreak of 1919 (Lee, 2018: 115-116), but also an emphasis that the battle against the microbe was something domestic, and perhaps female responsibility, by comparing the ordinary confines of two family homes (Chung, 2014). Similar scenes were widely found across cultural contexts. In South Africa, for example, films such as Two Brothers (1940) and Two Families (1942) zoomed in and compared the characteristics of households, where epidemics were likely to be seeded in slovenly and lazy households (Jeeves, 2003: 119-120). This relied not only on strength and clarity of message, but appeal of viewing context (on the popularity of public cinema in black communities in 1930s and 1940s South Africa and Rhodesia, for example: Nasson, 1989; Burns, 2003) and distribution. Accordingly, images were shown in multiple screenings in collective contexts such as meeting halls, schools, and exhibits put on by both medical officials and missionaries, as seen in China in the aftermath of the Manchurian plague of 1911, where material was so large that local laborers were paid day wages to carry the collections from place to place (Bu, 2010: 27). Significantly, many of the overtly militaristic and nationalistic messages became entrenched within the visual culture of disease management over time - not just the classic Maoist public health campaigns of the 1950s and 1960s in China, but even something seen in disease outbreaks (such as SARS) post-millennium (Hanson, 2008). In that sense, film - as with other forms of visual imagery - has never provided "neutral" public health information in connection with social responses to epidemics, but has been used to create moral, ideological, and politicized messages as well (Ostherr, 2020). These especially have focused on the concept of the "enemy within", the Other, and the interrelated notion of individual responsibility and collective well-being (Davis and Lohm, 2020: 26), with the reminder that individual health is inevitably connected to shared and communal spaces (Wald, 2008: 53), and epidemics the site 
of "chaos both social and personal" (Luckhurst, 2015: 122). Frequently, however, that "responsibility" has been thrown onto the shoulders of the poor and marginalized themselves (Jeeves, 2003: 116), while at the same time visual images downplaying structural causes connected to socio-economic development and politics.

\section{Outline of book structure and argumentation}

For clarity, the structure of the book and the basic threads of our argument are outlined here. In Chapter 2, upon organizing and analyzing our large collected corpus of films, we suggest that although societal reactions such as panic (an emotive response caused by fear) are typically found in films concerning epidemics, often this fear that the characters demonstrate is little associated with the disease itself. In fact, films show that epidemics can push societies in two directions: fear leading to a breakdown in sociability, and fear stimulating the preservation of tightly held social norms. The first social response to epidemics is often informed by concern over broader moral failings within society at large, leading, for example, to prejudice or violence. This fits logically with previous interpretative frameworks such as the previously mentioned "outbreak narrative" (Wald, 2008). The second social response to epidemics is often informed by the perceived application of arbitrary or excessive controls from above or outside the community in question - the Foucauldian notion of using sickness to exert social controls over a subject population as a form of "biopower" (for the original text: Foucault, 1995 [1975]: 195-200). Films have shown that epidemics produce active responses such as resistance or unrest, sometimes violent, to paradoxically retain aspects of normal life under threat (often from elites and authorities), such as perceived freedoms and liberties and customary traditions and practices. In that sense, we make a case for epidemics - at least as represented on screen-as being vehicles not for Foucauldian repression and surveillance, but as emancipatory instruments for citizens to reassess and critique their position in relation to authorities and institutions.

In Chapter 3, by zooming in on three films in particular, Contagion, Blindness (Fernando Meirelles, 2008), and The Painted Veil (John Curran, 2006), we suggest that the societal responses during epidemics seen in films are often driven or at least informed by pre-existing levels of distrust - which we conceptualize at three levels: institutional, social, and interpersonal. What we note is that the breakdown in trust seen at certain levels during the epidemics presented in these films - such as at the institutional level between ordinary communities and authorities or elites - might be mediated or negotiated, perhaps even compensated for, by heightened solidity of trust at the social level within or between communities. However, epidemics can also interact with pre-existing structural inequalities already entrenched within society — based on race, gender, or wealth - to create mixed outcomes of discord, prejudice, and fear that coexist with new forms of cohesion. That is to say, strengthened bonds of compassion and cohesion within communities often occur simultaneous to a strengthened line of demarcation 
between those within a community and those deemed to be on the outside and excluded.

In Chapter 4, we zoom out once again to the larger corpus of films already addressed in Chapter 2 to show some of the complexities of the breakdown in trust seen during epidemics - especially regarding interaction between elites and "ordinary people" - by focusing on the representation of public health workers. While recent literature has convincingly shown the development of the epidemiologist as a "culture hero" within cinema - and something that changes in nature over time-we suggest that the combination of professionalism and self-sacrifice sometimes are underpinned by particular human qualities seen in films that are distinctive but not straightforwardly favorable. Building on Christos Lynteris's "restoration of humanity" thesis (2016a), we actually argue that the heroic nature of the medical worker in many films - both recent and going back into the past - is exemplified in their capacity to show all-too-human flaws in personality, bringing them closer to "ordinary society". On occasion, the epidemic itself even serves as a context for the redemption of the medical professional, reminding them of their original role and privileged status (see also, Han and Curtis, 2021a).

In the final two chapters, we suggest that although epidemics can bring societies together at the communal level — while widening institutional distrust between communities and elites or authorities - films often show how certain social groups are often left behind, thereby heightening structural vulnerabilities. Indeed, we argue that cinema has often worked to entrench these inequalities-especially down gender and socio-economic lines. In Chapter 5, we show that in films, women frequently take on heavy burdens during epidemic outbreaks, often by selflessly caring for others. In extreme cases, this even leads to women sacrificing themselves for the "greater good" of the wider community or to protect a male protagonist. Moreover, women have often been portrayed as symbolic "carriers" or "spreaders" of disease - sometimes as a punishment - and this phenomenon is often connected to female characters seen deviating from their expected gender roles prescribed to them during epidemics (see also, Han and Curtis, 2021b). In that way, the two female images perpetuated by epidemic-related cinema interact with one another.

In Chapter 6, we suggest that films depicting epidemics often have offered differing representations of the connection between disease and poverty-often centered around different visual images of the physical environment - and has been used as a vehicle for broader critique of capitalism and globalization. In the past this was a distinction between elements of "rural backwardness" and "urban (moral) depravity", but also the uneasy distinction between the sanctitude and protection of the "rural idyll" (the escape from disease) and the "ignorant" and "underdeveloped" countryside (the nexus of disease). In more recent cinema, further distinction has been established between more sympathetic images of the "deserving poor", seen as "local" and part of the included community culture, and those "undeserving poor", usually migrants or those perceived as external to the community culture. 
In Chapter 7, which serves as a conclusion, we reflect upon the implications of our findings and argumentation for societies in or post-COVID-19. We draw similarities between images, motifs, and narratives used in film history, and those seen and perpetuated today as societies respond to this global pandemic. Three elements, in particular, are highlighted - (a) the mistakes of authorities and elites often leading to resistance and questioning from below, thus representing the inverse of the "biopower" narrative (notwithstanding important exceptions), (b) the continued perpetuation of Orientalist discourses, including a critique of China within an almost contradictory narrative of simultaneous under- and overdevelopment, and (c) the distinct epidemic experiences of women (and representation of those experiences). One major difference with societal responses to epidemics seen in cinema, and that of today's COVID-19 response, however, is the privileging of the "ordinary hero". In film, the saviors have and still remain elite or authority figures based around expertise - with their main role being to convince skeptical communities or to act in spite of sustained resistance and obstacles. It remains to be seen whether this narrative will be incorporated into future cinematic representation of epidemic outbreaks.

\section{Book approach and film database}

In this book we analyze the social responses to epidemics visualized in films by combining a macro approach to common patterns and tropes employed throughout a long cinematic history, with a more micro view of selected individual films of heightened relevance, using close reading of characters and social and historical contexts of film production. Our macro view is based on observations from a large database of epidemic-focused or epidemic-related films built from assorted indexes, catalogues, and secondary literature, and is the largest of its kind currently available (see Filmography). This allows us to identify commonalities, patterns, differences, and changes in the representation of societyepidemic interactions across geographical areas, but more importantly, across time. When we zoom in on specific films at a micro level, these choices are generally driven by relevance to the theme discussed, and the broader geopolitical perspective. Overall, our approach is grounded in cinema studies, to a certain extent, but as demonstrated in the elucidation of the book argument, informed by frameworks that have been developed in other disciplines touching the medical humanities such as social history, psychology, anthropology, and disaster studies.

The films database was constructed by first using various keyword combinations on the Internet Movie Database (IMDb), and second, manually filling in gaps using other catalogues and literature (Pappas et al., 2003; Kendal, 2021; Aberth, 2003; Vidal et al., 2007; García Sánchez et al., 2006; Vercruysse, 2014; Hart, 2013; Wijdicks, 2020) including the Wellcome Trust visual library (http://catalogue.wellcomelibrary.org/search/), the Japanese Animated Film Classics database (https:// animation.filmarchives.jp/en/index.html), the Prelinger Archives (https://archive. org/details/prelinger), the French MedFilm project (https://medfilm.unistra.fr/ 
wiki/Accueil:Accueil_site), the Bibliothèque Numérique Asiatique (www.bnasie. $\mathrm{eu} / \mathrm{BN} /$ Films), and the Chinese Film and the Cross-Cultural Medical Humanities Index (www.yimovi.com/en).

In the database, we include films about "real" epidemics, films about fictional epidemics loosely modeled on reality, and films dealing with themes of infection and contagion but from a fantastical viewpoint (for example, apocalypses or zombie invasions). We include films that have epidemics as central to the narrative as well as films with disease as a peripheral backdrop to an unrelated story. However, it should be noted that while this database also includes films dealing with HIV and/or AIDS, we do not discuss in the book any films about these infections at length (beyond passing reference where needed) given that this is an area that has already stimulated its own very specific debates and sizeable scholarly literature (only a selection of relevant examples: Foertsch, 2001; Pearl, 2004; Rees-Roberts, 2008; Qian, 2016; Li, 2016; Guerrero, 1990; Mathijs, 2003; Pilipp and Shull, 1993; Hart, 2013). Although including films dealing with HIV and/or AIDS was entirely possible, the number of these films is so large that we decided against it, as we did not want any one particular type of disease to dominate the narrative or analysis.

The filmography contains 393 films produced from 1910 to 2021, across 43 countries (some are joint collaborations between countries), and we include

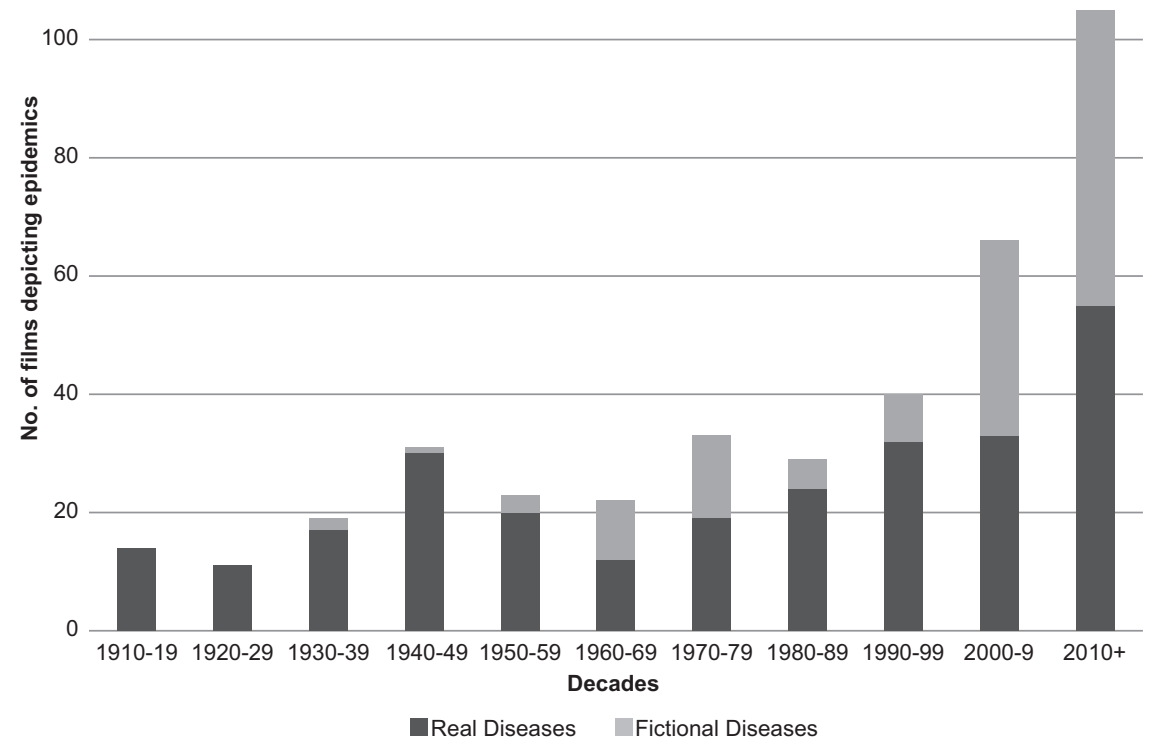

Figure 1.3 Temporal distribution of films in the film database

Source: Films listed in the Filmography. 
information on their title (original and international), year and place of production, director, and what kind of disease is being represented in the film, and whether it is fictional or not. In the following, we sketch out some basic general lines in the geographic and temporal development of the production of epidemics-related films. This is necessary given that it has been recognized that even within the confines of films concerned with issues of infection, contagion, and disease outbreak, conventions change over time-and sometimes within a matter of years (referred to as a specific representational cycle: Schweitzer, 2018).

Although educational films were prominent in the early stages of the cinematic depiction of epidemic and infectious disease, these were actually accompanied by or even preceded by a number of silent short and feature films that were essentially focused on moralizing entertainment such as A Man's Country (Henry Kolker, 1919), adaptations from classic literature such as Storia di una capinera (Giuseppe Sterni, 1917), or combined melodramas with educational values such as the short ten-minute The Temple of Moloch (Langdon West, 1914) - one of the earliest films in the database, which was part of the Edison Company's commitment to visualizing injustices within the industrialized working environment. From the 1920s onward, educational films became more important - in the West with the United States Public Health Service's How Disease Is Spread (1924), discussing the dangers of tuberculosis (analyzed in Ostherr, 2005: 5-11), but also in East Asia with a series of films that dealt with cholera, tuberculosis, and malaria such as Korea's Life's Enemy: Cholera, Taiwan's 预防霍乱 [Yufang huoluan/Preventing Cholera] (Anon., 1922), and Japan's Diseases Spread. Educational films - sometimes integrating light-hearted or humorous characters (see Disney's "seven dwarves" in Figure 1.4) - reappeared in large amounts during the Second World War period through animation, such as the escapades of a beleaguered soldier dealing with malaria in Private Snafu vs. Malaria Mike (Chuck Jones, 1944) or Disney's The Winged Scourge (Bill Justice, 1943), and relied on the reinforcement of xenophobic, racist, or misogynistic caricatures.

The periods of intense educational epidemic-related films, however, were interspersed in the 1930s by arguably a "golden age" of feature films about epidemics focusing more on entertainment through melodrama-from John Ford's revered depictions of doctors striving in the face of adversity to help their communities in the face of plague and typhoid fever such as Arrowsmith (1931) and Doctor Bull (1933), to those films developing the sacrificial female image, discussed at further length in Chapter 5, such as The Citadel (King Vidor, 1938), Jezebel (William Wyler, 1938), and The Rains Came (Clarence Brown, 1939), dealing with tuberculosis, yellow fever, and cholera, respectively. A number of these films and their actors were recognized with Academy Awards. ${ }^{6}$ What is noticeable from Figure 1.3 is that most of these dramatizations of the lives of doctors and communities during epidemic outbreaks centered on societal responses to real diseasestheir spread, transmission, and impact presented in line with what was generally 


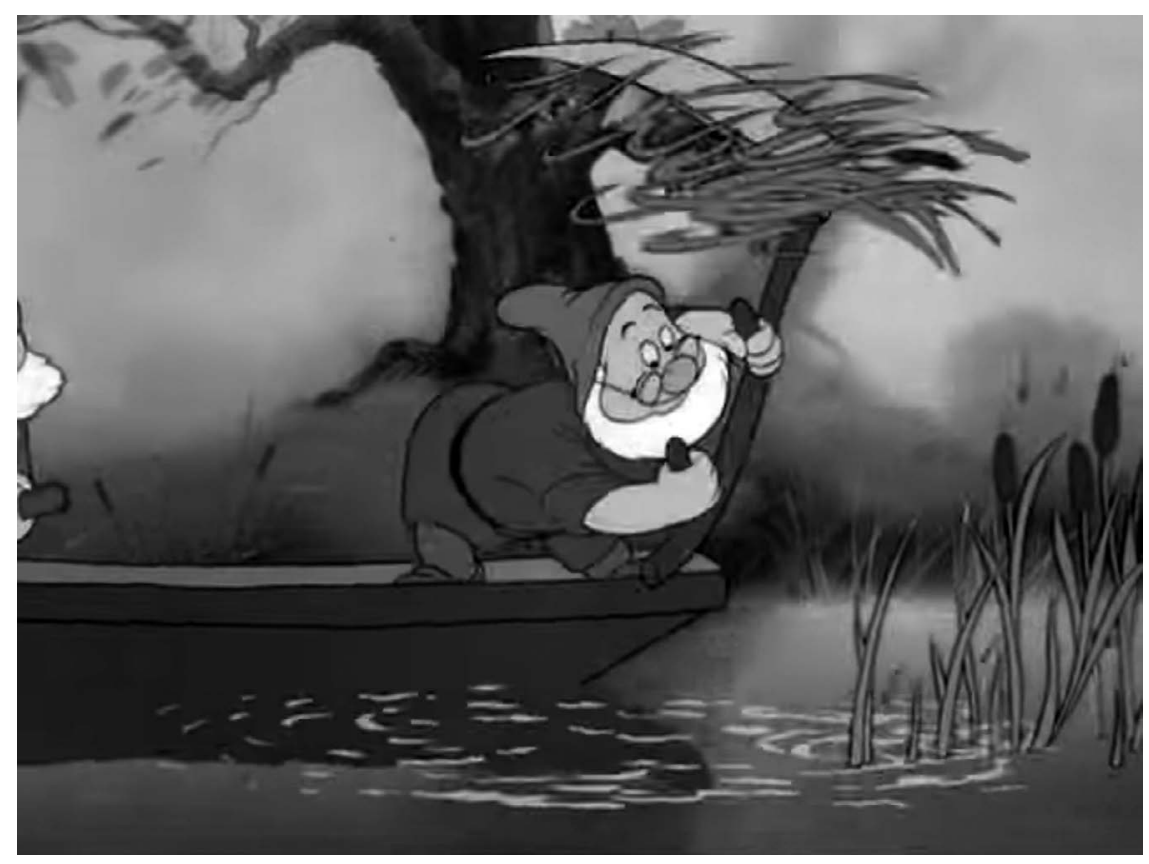

Figure 1.4 "Doc" dealing with the water reeds in The Winged Scourge (Bill Justice, 1943) Source: Captured from personal copy.

understood about the diseases at the time. To a certain extent, this continued in the period after the Second World War into the 1950s with popular pictures such as The Killer That Stalked New York (Earl McEvoy, 1950) and Panic on the Streets (Elia Kazan, 1950), which dealt with smallpox (based on the real threat of a smallpox outbreak a few years earlier) and pneumonic plague respectively-and were fixated on concerns over illegal immigration and smuggling as the causes of disease. ${ }^{7}$

One of the new products of the post-Second World War environment with regard to epidemic-related filmmaking, however, was the change in perceived enemies. Those threatening public health were not necessarily selfish individuals or groups within small communities, as seen in many of the 1930s films, but states, governments, and officials in line with the diplomatic tensions of the Cold War. Those responsible for the poisoned water in William Cameron Menzies's The Whip Hand (1951), leading to epidemic disease, was even changed from the Nazis in the original script to communists in the revised script—one of a series of so-called "red scare" pictures produced at that time (Anon., 2014b). Meanwhile, the emergence of the People's Republic of China in 1949 created other conflicts-in this case in the tension between Western medicine and "homegrown" 
Chinese medicine dispensed by "elite" urban medics or rustic "barefoot doctors" (Fang, 2019; Gross, 2018; Li, 2015) who treated diseases that threatened the health of rural communities such as schistosomiasis (caused by water-borne parasitic flatworms) - and thus visualized in such rustic pictures as 枯木逢春 [Kumu fengchun/Spring Comes to the Withered Tree] (Zheng Junli, 1961), and continued into the 1970s with 红雨 [Hong yu/Red Rain] (Cui Wei, 1975).

More substantial stylistic changes can be discerned from the 1960s onwards. As seen from Figure 1.3, a larger proportion of films depicting epidemics started to revolve around diseases that were fictional - either only very loosely related to real diseases or sometimes afflictions that were beyond the realms of possibility or acting as a metaphor for other social processes. Only a few exceptions can be discerned, particularly in Eastern Europe or Soviet cinema - such as the Yugoslavian film Variola vera (Goran Markovic, 1982) that dramatized the earlier events of the 1972 smallpox outbreak within the claustrophobic environment of a Belgrade hospital (Mandić, 2019: 505), or the Polish film Zaraza/The Epidemic (Roman Zaluski, 1972) that was based on another smallpox outbreak in 1963 in Wroclaw (Kunicki, 2021), or the Soviet film В город пришла беда [ $V$ gorod prishla beda] (Mark Orlov, 1966) that depicted events based on smallpox in Moscow a few years earlier. Partially, this change may have been a product of the times - an over-optimistic consensus that the human battle against infectious disease had been won (Snowden, 2008; Green, 2020b), at least in the West, and thus necessitating the creation of new fantastical afflictions. Indeed, smallpox came to be resigned to the past with vaccination in the 1970s. Films involving afflictions connected to poverty such as tuberculosis were frequently found in the first half of the twentieth century (providing a rich source of moralizing narrative), but mirroring epidemiologic trends, they largely disappear after 1970 - only appearing again in more recent years in films explicitly set in the past (Rovello et al., 2018). ${ }^{8}$

It may also be related to two other broad developments. The first, more closely linked to the concerns of the Cold War, is that films started to more explicitly focus on societal worries about acts of poisoning or contamination - either accidently through dubious forms of scientific research (linked also the "mad" or "diabolical" scientist trope: Jones, 2001) or deliberately in the form of bioterrorism ("biohorror" or "epidemiological horror" scenarios according to Wald, 2012: 99-100). Soviet films such as Карантин [Karantin/Quarantine] (Sulamif Tsybulnik, 1968) zoomed in on scenarios within an epidemiological research laboratory where a virus has to be contained (Dolgopolov, 2021). In Western films such as The Man Who Wouldn't Talk (Herbert Wilcox, 1958) and Suspect/The Risk (John Boulting/ Ray Boulting, 1960), specific concern was over dangerous secrets related to pathogens (and their cures) falling into the wrong hands. The James Bond series was not immune to this trend - the one and only picture starring George Lazenby, On Her Majesty's Secret Service (Peter R. Hunt, 1969), presented the dastardly Blofeld (Telly Savalas) brainwashing women to distribute bacteriological warfare agents. Original scripts also began to be revised. A mutant infection was spread by bats and mosquitos in the 1954 book, I Am Legend, and yet this was replaced by biological warfare in the film adaptation The Omega Man (Boris Sagal, 1971). The second development was the emergence of the science-fiction (sci-fi) genre, 
which for some films such as The Andromeda Strain (Robert Wise, 1971), linked all three aspects together-scientific research going wrong, public anxiety over biological warfare, and extraterrestrial activity (Dinello, 2005: 253-254). This trend was later-from the 1980s onwards - magnified further by the proliferation of the computer, and emerging popular consciousness of the "computer virus" leading to new forms of infection paranoia (Weinstock, 1997: 89-93).

Films such as Night of the Living Dead (George A. Romero, 1968) ushered in a new age of epidemics as central to horror films, linking together medical and military authority (Pokornowski, 2013: 218), and mainly featuring undead corpses and mutants as products of various forms of infection such as Shivers (David Cronenberg, 1975) and Rabid (David Cronenberg, 1977), but also linking with an earlier tradition of vampires as seen in the likes of The Last Man on Earth (Ubaldo Ragona/Sidney Salkow, 1964), Vampire Circus (Robert Young, 1972), Léonor (Juan Luis Buñuel, 1975), and Nosferatu: Phantom der Nacht (Werner Herzog, 1979). ${ }^{9}$ Indeed, the last-mentioned film explicitly drew upon classic images of known plague vectors such as rats and fleas (Castel et al., 2013: 364; see Figure $1.5),{ }^{10}$ and photos can be found of director Herzog hand-painting 11,000 live rats while filming in the streets of Schiedam in the Netherlands (the nearby town of Delft refused permission). Accordingly, it came to be explicitly recognized that a proliferation of epidemic-related films had emerged across the 1970s and 1980s "built around more outlandish forms of disseminating parasitism (i.e., vampirism, body-snatching aliens)" (Foreman Jr., 1995: 4; also, Cooke, 2009: 14-15).

Although fears of the "enemy within" had already started to be visualized in the 1960s with the likes of Masque of the Red Death (Roger Corman, 1964) - the classic image of Prospero cowering in the confines of his castle away from those on the outside (Christol, 2010: 98) - it was the Cold War and AIDS concerns

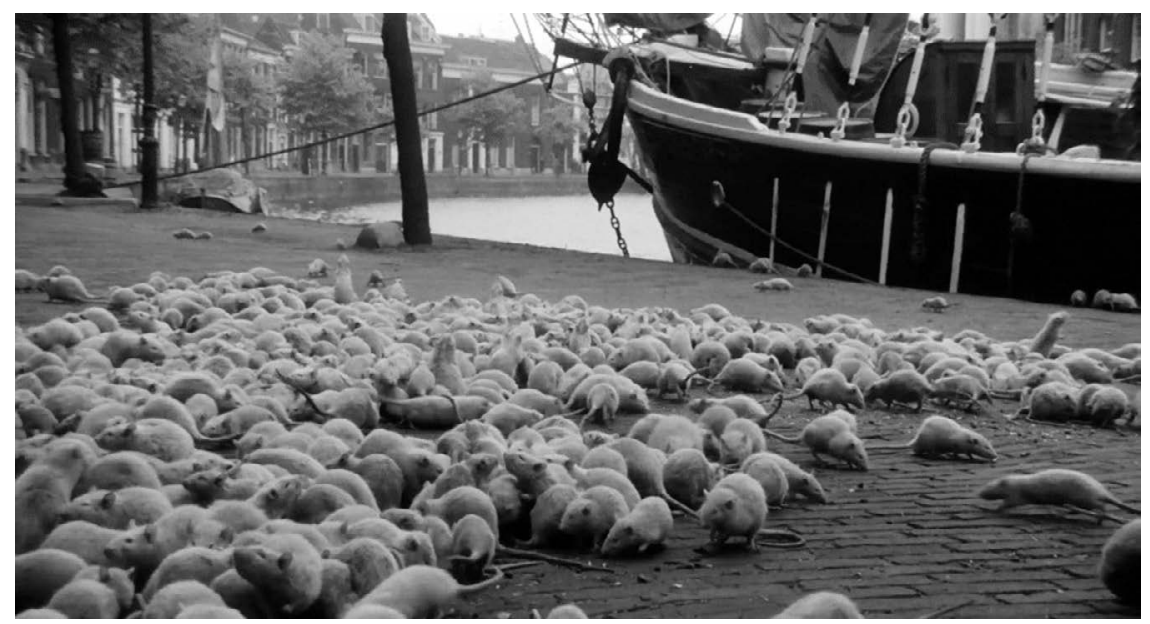

Figure 1.5 "Rats" in Nosferatu: Phantom der Nacht (Werner Herzog, 1979)

Source: Captured from personal copy. 
that combined together to create new binaries connected to a global threat. Films increasingly started to present those on the inside (as the healthy) and those on the outside (as the infected) (Foertsch, 2001: 30, 96, 106), and an "us" and "them" dichotomy as a new type of "plague metaphor" (Allan, 2002: 128). AIDS, of course, was the system shock that destroyed the over-optimistic "victory over the microbe" narrative (Sontag, 2002: 158), but the combination of political ideology (Reaganism/Thatcherism) and societal prejudices limited the number of realistic or nuanced films explicitly dealing with this new affliction - only increasing in number from the 1990s onwards. Instead, films such as (the remake of) The Fly (David Cronenberg, 1986) had indirect allegorical links to HIV and AIDS-with a particular focus on the "corrupted" deterioration of the body (Guerrero, 1990; Pheasant-Kelly, 2016: 242-243).

The 1980s and 1990s saw a series of highly acclaimed films involving epidemics - drawing upon complex themes connected to existentialism, austerity, and the relationship between humans and the natural environment in the likes of Epidemic (Lars von Trier, 1987), The Hole, and 盗马贼 [Daoma zei/The Horse Thief] (Tian Zhuangzhuang, 1986). Environmental issues remained at the heart of epidemic-related films as we crossed from the twentieth to the twenty-first century - although this time Outbreak (Wolfgang Petersen, 1995) and Contagion broadened the spatial scope away from the individual locality (the underdeveloped village or the depraved, polluted, over-populated, and decadent city) and more towards a critique on the dynamics of modern capitalism, inequality, and globalization.

During the 1990s and post-2000, however, one of the most important trends within films depicting epidemics was the re-centering of zombie infections (on this spike: Zimmerman and Mason, 2017: 59; Pokornowski, 2013: 221); sometimes, though not always, integrated within apocalyptical scenarios or a pandemic (often caused by a fictional virus) wiping out large amounts of humanity. Indeed, awareness of the prevalence of this format also created new avenues for comedy in the form of irony and satire - the British cult-classic Shaun of the Dead (Edgar Wright, 2004) or the Argentinian Fase 7 (Nicolás Goldbart, 2010) as cases in point. From roughly 2005 onwards, arguably the most persistent theme in epidemics-related films up to now is the continuation of the "death of all humanity" scenario, but framed within a different kind of disease representation: an infection or debilitation that eats away or disturbs the senses, and is something seen in a variety of filmmaking contexts from North and South America, to East Asia, and Western Europe-see as relevant examples the likes of エリ・エリ・レマ・サバクタ二 [Eri eri rema sabakutani/My God, My God, Why Hast Thou Forsaken Me?] (Shinji Aoyama, 2005), Pontypool (Bruce McDonald, 2008), Blindness (Fernando Meirelles, 2008), Fase 7 (Nicolás Goldbart, 2010), Perfect Sense (David Mackenzie, 2011), Los últimos días (David Pastor/Alex Pastor, 2013), Embers (Claire Carré, 2015), Equals (Drake Doremus, 2015), and The Darkest Minds (Jennifer Yuh Nelson, 2018). 
Finally, post-2010, the growing creative and financial power of East Asian cinema - and more particularly fueled via mainland Chinese market demandhas led to a series of incredibly high grossing films of which Wolf Warrior 2 and the Korean 부산행 [Busanhaeng/Train to Busan] (Sang-ho Yeon, 2016) are arguably the most prominent. Indeed, just at the time of writing, a new Korean film dealing with a lockdown situation within an apartment during a zombie infection, \#살아있다 [Saraitda/Alive] (Cho Il-hyung, 2020) has made its way onto Netflix screens. It remains to be seen where cinematic depiction of epidemics will go in the post-COVID age, although relevant films have already been producedtitles such as Songbird (Adam Mason, 2020), Homemade (various, 2020), Putham pudhu kaalai [A Brand New Dawn] (Sudha Kongara and others, 2020), Locked Down (Doug Liman, 2021) - and producing whole new debates over societal responsibility, exploitation, tastefulness, and filmmaking ethics.

\section{Notes}

1 In this book, we use a convention of listing a film mentioned for the first time in full with its title, director, and year of release. We provide the title of the film in the original language of production, and only for films with titles in non-Romanized languages do we provide either the official English translation for international markets or if not present then a Romanized deconstruction of the original title (for example, in pinyin). For all films mentioned subsequently, we use only the translated title without additional information - in the interest of space. Full information for all films, however, can be found in the filmography at the end of the book, including translation details.

2 "Amid a pandemic, an ailing man waits for his illness to overtake him while being shuttled between hospitals as doctors try to pinpoint a diagnosis". www.netflix.com/ title/70041148, UK Netflix, as accessed on 19/11/2020. There is no pandemic in this film.

3 The effect of films on societal attitudes has recently been tested through formal statistical analysis in a historical setting (Ang, 2021) - establishing a clear link between heightened levels of racist violence and Ku Klux Klan membership in the aftermath of those localities in the United States that screened the film The Birth of a Nation (D.W. Griffith, 1915).

4 Although coining the term "outbreak narrative", an earlier work had already introduced "emerging-virus narratives" linking different forms of media, literature, and popular culture (Schell, 1997).

5 Although, of course, throughout the twentieth century, surgical films were routinely exhibited to world audiences without consideration of the patient's wishes and without recognition of this contribution to medical knowledge (Ostherr, 2013), something that was even more the case for indigenous patients in colonized settings.

6 In this book, we use the term "actor" as gender neutral.

7 Also, in Elia Kazan's later film from 1963, America America, there is inclusion of a scene whereby a man fleeing the Hamidian massacres of Armenian communities in the Ottoman Empire in the late nineteenth century is unable to emigrate to the United States, on account of contracting tuberculosis.

8 The play by Tennessee Williams, The Seven Descents of Myrtle, for example, was adapted for screen in 1970 by Gore Vidal, but the man seriously ill with tuberculosis is replaced by a cancer sufferer in the film (Phillips, 2002). 
9 On the interrelationship between vampires and zombies in the context of disease and infection (the "cross-fertilizing of tropes of the zombie with the vampire"), see (Abbott, 2016: 40-42).

10 Similarly, in the original 1922 adaptation of Bram Stoker's 1897 novel Dracula, Nosferatu, eine Symphonie des Grauens (F.W. Murnau, 1922), a major departure from the literary version is the inclusion of Count Orlok arriving in Wisborg by ship, bringing with him an infestation of rats that lead to a plague outbreak in the town. The film then goes on to perpetuate anti-Semitic stereotypes such as the link between Orlok and rats, and the general notion of Jews as agents of disease (Magistrale, 2005: 25-26).

\section{References}

Abbott, Stacey. Undead Apocalypse: Vampires and Zombies in the 21st Century. Edinburgh: Edinburgh University Press, 2016.

Aberth, John. "Welcome to the Apocalypse: Black Death Films." In: John Aberth (ed.), $A$ Knight at the Movies: Medieval History on Film, pp. 197-254. New York: Routledge, 2003.

Allan, Stuart. Media, Risk and Science. Buckingham: Open University Press, 2002.

Ang, Desmond. "The Birth of a Nation: Media and Racial Hate." Working Paper (2021), https://scholar.harvard.edu/ang/publications/birth-nation-media-and-racial-hate.

Anon. "CDC's Disease Detectives: Contagion, the Movie: Hollywood's Take on Disease Detectives." $C D C$, March 19, 2014a, www.cdc.gov/about/24-7/savinglives/disease_dete ctives/contagion_hollywood.html.

Anon. "The Blacklist: It's Not Just History." Cinéaste 40, 1 (2014b): 1.

Anon. "Hollywood and Health Researchers Team Up to Boost Minority Participation in Clinical Research.” SC CTSI, April 10, 2017, https://sc-ctsi.org/news/hollywood-andhealth-researchers-team-up-to-boost-minority-participation-in-clinical-research.

Anon. "Images of COVID-19: Decent Exposure." The Economist, August 15-21, 2020b: 67-68.

Belling, Catherine. "Overwhelming the Medium: Fiction and the Trauma of Pandemic Influenza in 1918." Literature and Medicine 28, 1 (2009): 55-81.

Bergesen, Albert. "How to Sociologically Read a Movie.” The Sociological Quarterly 57, 4 (2016): 585-596.

Blakey, Shannon M., Lilian Reuman, Ryan J. Jacoby and Jonathan S. Abramowitz. "Tracing 'Fearbola': Psychological Predictors of Anxious Responding to the Threat of Ebola." Cognitive Therapy and Research 39, 6 (2015): 816-825.

Bohstedt, John. "Food Riots and the Politics of Provisions from Early Modern Europe and China to the Food Crisis of 2008." Journal of Peasant Studies 43, 5 (2016): 1035-1067.

Brown, Brandon, Melissa Nasiruddin, Alexander Dao and Monique Halabi. "Responsible Use of Pop Culture and Communication in the Face of Ebola Virus." PLoS Neglected Tropical Diseases 9, 8 (2015): e0003890.

$\mathrm{Bu}$, Liping. "Cultural Communication in Picturing Health: W. W. Peter and Public Health Campaigns in China, 1912-1926.” In: David Serlin (ed.), Imagining Illness: Public Health and Visual Culture, pp. 24-39. Minneapolis, MN: University of Minnesota Press, 2010.

Budd, Michael Anton. "Composing and Decomposing Bodies: Visualizing Death and Disease in an Era of Global War, Pestilence, and Famine, 1913-1923." In: Christos Lynteris and Nicholas H.A. Evans (eds.), Histories of Post-Mortem Contagion: Medicine and Biomedical Sciences in Modern History, pp. 135-164. Cham: Palgrave Macmillan, 2018. 
Burns, James. “A Source of Innocent Merriment: Cinema and Society in Colonial Zimbabwe." South African Historical Journal 48, 1 (2003): 130-137.

Castel, Olivier, A. Bourry, S. Thévenot and C. Burucoa. "Bactéries et vampirisme au cinéma." Médecine et Maladies Infectieuses 43, 9 (2013): 363-367.

Christol, Florent. "La gore, modalité virale du cinéma hollywoodien." Cinémas: revue d'études cinématographiques 20, 2-3 (2010): 97-117.

Chung, Steven. Split Screen Korea: Shin Sang-ok and Postwar Cinema. Minneapolis, MN: University of Minnesota Press, 2014.

Cohn, Samuel Kline. Epidemics: Hate and Compassion from the Plague of Athens to AIDS. Oxford: Oxford University Press, 2018.

Cooke, Jennifer. Legacies of Plague in Literature, Theory and Film. Basingstoke: Palgrave Macmillan, 2009.

Curtis, Daniel R. and Bram van Besouw. "Not Learning from History: Learning from COVID-19." Wiley: COVID-19 Resources for the Research Community, April 4, 2020 , www.wiley.com/network/researchers/covid-19-resources-for-the-research-community/ not-learning-from-history-learning-from-covid-19.

Darbyshire, Daniel and Paul Baker. "A Systematic Review and Thematic Analysis of Cinema in Medical Education.” Medical Humanities 38, 1 (2012): 28-33.

Davis, Mark and Davina Lohm. Pandemics, Publics, and Narrative. Oxford: Oxford University Press, 2020.

Davis, Mark and Lenore Manderson, eds. Disclosure in Health and Illness. Abingdon: Routledge, 2014.

Davis, Ryan A. The Spanish Flu: Narrative and Cultural Identity in Spain, 1918. New York: Palgrave Macmillan, 2013.

Dehority, Walter. "Infectious Disease Outbreaks, Pandemics, and Hollywood: Hope and Fear across a Century of Cinema." JAMA 323, 19 (2020): 1878-1880.

Dinello, Daniel. Technophobia! Science Fiction Visions of Posthuman Technology. Austin, TX: University of Texas Press, 2005.

Doherty, Jane and James Giordano. "What We May Learn - and Need-From Pandemic Fiction." Philosophy, Ethics, and Humanities in Medicine 15, 4 (2020), https://peh-med. biomedcentral.com/articles/10.1186/s13010-020-00089-0.

Dolgopolov, Greg. "Russian Screen Responses to the Pandemic." Apparatus: Film, Media and Digital Cultures in Central and Eastern Europe 12 (2021), http://dx.doi. org/10.17892/app.2021.00012.249.

Fang, Xiaoping. "Changing Narratives and Persisting Tensions: Conflicts between Chinese and Western Medicine and Professional Profiles in Chinese Films and Literature, 1949-2009." Medical History 63, 4 (2019): 454- 474.

Fisher, Jane Elizabeth. Envisioning Disease, Gender and War: Women's Narratives of the 1918 Influenza Pandemic. New York: Palgrave Macmillan, 2012.

Foertsch, Jacqueline. Enemies Within: The Cold War and the AIDS Crisis in Literature, Film, and Culture. Chicago, IL: University of Illinois Press, 2001.

Foreman Jr., Christopher H. "Editorial Commentary: Witchcraft Science in the Cinema of Epidemics." Science Communication 17, 1 (1995): 3-8.

Foucault, Michel. Discipline and Punish: The Birth of the Prison. New York: Vintage Books, 1995 [1975].

García Sánchez, Jose Elías, Enrique García Sánchez and Maria Lucila Merino Marcos. "Antibacterial Agents in the Cinema." Revista española de quimioterapia: publicación oficial de la Sociedad Española de Quimioterapia 19 (2006): 397-402.

Gilman, Sander L. "Moral Panic and Pandemics.” The Lancet 375, 9729 (2010): 1866-1867. 
Görgen, Arno, German Alfonso Nunez and Heiner Fangerau. "The Medicalization of Popular Culture: Epistemical, Ethical and Aesthetical Structures of Biomedical Knowledge as Cultural Artefact." In: Arno Görgen, German Alfonso Nunez and Heiner Fangerau (eds.), Handbook of Popular Culture and Biomedicine: Knowledge in the Life Sciences as Cultural Artefact, pp. 1-14. Cham: Springer, 2019.

Green, Monica H. "Emerging Diseases, Re-Emerging Histories." Centaurus: An International Journal of the History of Science and Its Cultural Aspects 62, 2 (2020b): 234-247.

Green, Monica H., Kathleen Walker-Meikle and Wolfgang P. Müller. "Diagnosis of a 'Plague' Image: A Digital Cautionary Tale.” The Medieval Globe 1, 1 (2014): 309-326.

Gross, Miriam. "Between Party, People, and Profession: The Many Faces of the 'Doctor' during the Cultural Revolution." Medical History 62, 3 (2018): 333-359.

Guerrero, Edward. "AIDS as Monster in Science Fiction and Horror Cinema." Journal of Popular Film and Television 18, 3 (1990): 86-93.

Han, Qijun and Daniel R. Curtis. "Social Responses to Epidemics Depicted by Cinema." Emerging Infectious Diseases 26, 2 (2020): 389-394.

Han, Qijun and Daniel R. Curtis. 'Epidemics, Public Health Workers, and 'Heroism' in Cinematic Perspective.” Visual Studies (2021a), early online, https://www.tandfonline. com/doi/full/10.1080/1472586X.2021.1907781.

Han, Qijun and Daniel R. Curtis. "The Female Burden Visualized: Cinematic Representation of Women during Epidemics." Journal of Popular Culture 95, 6 (2021b), early online, https://onlinelibrary.wiley.com/doi/10.1111/jpcu.13070?af=R.

Han, Qijun and Daniel R. Curtis. "Suspicious Minds: Cinematic Depiction of Distrust during Epidemic Disease Outbreaks." Medical Humanities 47, 2 (2021d): 248-256.

Hanson, Marta. "Maoist Public-Health Campaigns, Chinese Medicine, and SARS." The Lancet 372, 9648 (2008): 1457-1458.

Hart, Kylo-Patrick R. The AIDS Movie: Representing a Pandemic in Film and Television. New York: Routledge, 2013.

Healy, Margaret. Fictions of Disease in Early Modern England: Bodies, Plagues and Politics. Basingstoke: Palgrave Macmillan, 2001.

Herrick, Clare. "Geographic Charisma and the Potential Energy of Ebola." Sociology of Health and Illness 41, 8 (2019): 1488-1502.

Hilkens, Bram, Bram van Besouw and Daniel R. Curtis. "A Modern Rendition of a PreModern Scenario: Imperfect Institutions and Obscured Vulnerabilities." Journal for the History of Environment and Society 5 (2020): 211-221.

Hofman, Michiel and Sokhieng Au, eds. The Politics of Fear: Médecins sans Frontières and the West African Ebola Epidemic. Oxford: Oxford University Press, 2017.

Horton, Richard. “Offline: 2019-nCoV: A Desperate Plea.” The Lancet 395, 10222 (2020): 400.

Jacobsen, Michael. "Spectacular Death: Proposing a New Fifth Phase to Philippe Ariès's Admirable History of Death." Humanities 5, 2 (2016): 1-20.

Jeeves, Alan. "The State, the Cinema, and Health Propaganda for Africans in Pre-Apartheid South Africa, 1932-48." South African Historical Journal 48, 1 (2003): 109-129.

Jones, Esyllt W. "Politicizing the Laboring Body: Working Families, Death, and Burial in Winnipeg's Influenza Epidemic, 1918-1919.” Labor 3, 3 (2006): 57-75.

Jones, Lori and Richard Nevell. "Plagued by Doubt and Viral Misinformation: The Need for Evidence-Based Use of Historical Disease Images." Lancet Infectious Diseases 16, 10 (2016): e235-e240.

Jones, Robert A. "Why Can't You Scientists Leave Things Alone? Science Questioned in British Films of the Post-War Period (1945-1970)." Public Understanding of Science 10, 4 (2001): 365-382. 
Jurecic, Ann. Illness as Narrative. Pittsburgh, PA: University of Pittsburgh Press, 2012.

Kendal, Evie. "Public Health Crises in Popular Media: How Viral Outbreak Films Affect the Public's Health Literacy." BMJ: Medical Humanities 47, 1 (2021): 11-19.

King, Helen and Monica H. Green. "On the Misuses of Medical History." The Lancet 391, 10128 (2018): 1354-1355.

King, Nicholas B. "Mediating Panic: The Iconography of 'New' Infectious Threats, 19362009." In: Robert Peckham (ed.), Empires of Panic: Epidemics and Colonial Anxieties, pp. 181-202. Hong Kong: Hong Kong University Press, 2015.

Kirby, David A. "Science and Technology in Film: Themes and Representations." In: Massimiano Bucchi and Brian Trench (eds.), Routledge Handbook of Public Communication of Science and Technology, 2nd ed., pp. 97-112. New York: Taylor and Francis, 2014.

Kirby, David A. "The Changing Popular Images of Science.” In: Kathleen Hall Jamieson, Dan M. Kahan and Dietram Scheufele (eds.), The Oxford Handbook of the Science of Science Communication, pp. 1-18. Oxford: Oxford University Press, 2017.

Kracauer, Siegfried. Theory of Film: The Redemption of Physical Reality. Princeton, NJ: Princeton University Press, 1997 [1960].

Kruvand, Marjorie and Maggie Silver. "Zombies Gone Viral: How a Fictional Zombie Invasion Helped CDC Promote Emergency Preparedness." Case Studies in Strategic Communication 2 (2013): 34-60.

Kudlick, Catherine. "Smallpox, Disability, and Survival in Nineteenth-Century France: Rewriting Paradigms from a New Epidemic Script.” In: Susan Burch and Michael Rembis (eds.), Disability Histories, pp. 185-200. Urbana, IL: University of Illinois Press, 2014.

Kunicki, Mikolaj. “'Medical Doctors Rule the City': Roman Załuski's Zaraza/The Epidemic and the 1963 Smallpox Outbreak in Wrocław." Apparatus: Film, Media and Digital Cultures in Central and Eastern Europe 12 (2021), http://dx.doi.org/10.17892/ app.2021.00012.253.

Lederer, Susan E. "Dark Victory: Cancer and Popular Hollywood Film." Bulletin of the History of Medicine 81, 1 (2007): 94-115.

Lee, Daw-Ming. "Enlightenment, Propaganda, and Image Creation: A Descriptive Analysis of the Usage of Film by the Taiwan Education Society and the Colonial Government before 1937.” In: Emilie Yueh-yu Yeh (ed.), Early Film Culture in Hong Kong, Taiwan, and Republican China, pp. 101-133. Ann Arbor, MI: University of Michigan Press, 2018.

Li, Lan Angela. "The Edge of Expertise: Representing Barefoot Doctors in Cultural Revolution China." Endeavour 39, 3-4 (2015): 160-167.

Li, Li. "Alone Together: Contagion, Stigmatization and Utopia as Therapy in Zhao Liang's AIDS Documentary Together." In: Howard Y.F. Choy (ed.), Discourses of Disease: Writing Illness, the Mind and the Body in Modern China, pp. 231-251. Leiden: Brill, 2016.

Luckhurst, Roger. Zombies: A Cultural History. London: Reaktion Books, 2015.

Lynteris, Christos. "The Epidemiologist as Culture Hero: Visualizing Humanity in the Age of the Next Pandemic." Visual Anthropology 29, 1 (2016a): 36-53.

Magistrale, Tony. Abject Terrors: Surveying the Modern and Postmodern Horror Film. New York: Peter Lang, 2005.

Mandić, Marina. "Between the Real and the Imagined: Variola Vera Epidemic in the Area of Yugoslavia through Film Narrative." Issues in Ethnology and Anthropology 14, 2 (2019): 487-505.

Mathijs, Ernest. "AIDS References in the Critical Reception of David Cronenberg: 'It May Not Be Such a Bad Disease after All'.” Cinema Journal 42, 4 (2003): 29-45. 


\section{Epidemics through the cinematic lens}

McGuire, Kelly. "COVID-19, Contagion, and Vaccine Optimism.” Journal of Medical Humanities 42, 1 (2021): 51-62.

Millard, William B. "Ebola Preparedness: On Avoiding Making a Scary Virus Scarier." Annals of Emergency Medicine 65, 2 (2015): 15-20.

Mitman, Gregg. "The Color of Money: Campaigning for Health in Black and White America." In: David Serlin (ed.), Imagining Illness: Public Health and Visual Culture, pp. 40-61. Minneapolis, MN: University of Minnesota Press, 2010.

Mullens, Lauri. Leaky Bodies: Epidemic Disease in Contemporary American Television. Ph.D. Thesis, University of Southern California, 2004.

Muzzatti, Stephen L. "Bits of Falling Sky and Global Pandemics: Moral Panics and Severe Acute Respiratory Syndrome (SARS)." Illness, Crisis and Loss 13, 2 (2005): 117-128.

Nasiruddin, Melissa, Monique Halabi, Alexander Dao, Kyle Chen and Brandon Brown. "Zombies: A Pop Culture Resource for Public Health Awareness." Emerging Infectious Diseases 19, 5 (2013): 809-813.

Nasson, William Richard. “'She Preferred Living in a Cave with Harry the Snake Catcher:' Towards an Oral History of Popular Leisure and Class Expression in District Six, Cape Town, c. 1920-1950." In: Philip Bonner, Isabel Hofmeyr, Deborah James and Tom Lodge (eds.), Holding Their Ground: Class, Locality and Culture in Nineteenth and Twentieth Century South Africa, pp. 285-309. Johannesburg: Witwatersrand University Press, 1989.

Ostherr, Kirstin. "Contagion and the Boundaries of the Visible: The Cinema of World Health." Camera Obscura: Feminism, Culture, and Media Studies 17, 2 (2002): 1-40.

Ostherr, Kirstin. Cinematic Prophylaxis: Globalization and Contagion in the Discourse of World Health. Durham, NC: Duke University Press, 2005.

Ostherr, Kirstin. Medical Visions: Producing the Patient through Film, Television, and Imaging Technologies. New York: Oxford University Press, 2013.

Ostherr, Kirstin. "How Do We See COVID-19? Visual Iconographies of Racial Contagion." American Literature 92, 4 (2020): 707-727.

Paffenroth, Kim. "Zombies as Internal Fear or Threat." In: Stephanie Boluk and Wylie Lenz (eds.), Generation Zombie: Essays on the Living Dead in Modern Culture, pp. 18-26. Jefferson, NC: McFarland, 2011.

Pappas, Georgios, Savvos Seitaridis, Nikolaos Akritidis and Epaminondas Tsianos. "Infectious Diseases in Cinema: Virus Hunters and Killer Microbes." Clinical Infectious Diseases 37, 7 (2003): 939-942.

Pearl, Monica B. “AIDS and New Queer Cinema." In: Michele Aaron (ed.), New Queer Cinema: A Critical Reader, pp. 23-36. Edinburgh: Edinburgh University Press, 2004.

Peckham, Robert. "Panic Encabled: Epidemics and the Telegraphic World." In: Robert Peckham (ed.), Empires of Panic: Epidemics and Colonial Anxieties, pp. 131-154. Hong Kong: Hong Kong University Press, 2015.

Pheasant-Kelly, Frances. "Towards a Structure of Feeling: Abjection and Allegories of Disease in Science Fiction 'Mutation' Films." BMJ Medical Humanities 42 (2016): 238-245.

Phillips, Gene D. “Tennessee Williams's Forgotten Film: The Last of the Mobile Hot Shots as a Screen Version of the Seven Descents of Myrtle.” In: Philip C. Kolin (ed.), The Undiscovered Country: The Later Plays of Tennessee Williams, pp. 69-79. New York: Peter Lang, 2002.

Pilipp, Frank and Charles Shull. "American Values and Images: TV Movies of the First Decade of AIDS.” Journal of Popular Film and Television 21, 1 (1993): 19-26. 
Pokornowski, Steven. "Insecure Lives: Zombies, Global Health, and the Totalitarianism of Generalization.” Literature and Medicine 31, 2 (2013): 216-234.

Qian, Kun. "Reluctant Transcendence: AIDS and the Catastrophic Condition in Gu Changwei's Film Love for Life." In: Howard Y.F. Choy (ed.), Discourses of Disease: Writing Illness, the Mind and the Body in Modern China, pp. 203-230. Leiden: Brill, 2016.

Rees-Roberts, Nick. “Queer Sexuality, AIDS and Loss.” In: Nick Rees-Roberts (ed.), French Queer Cinema, pp. 89-128. Edinburgh: Edinburgh University Press, 2008.

Ricoeur, Paul. Hermeneutics and the Human Sciences: Essays on Language, Action and Interpretation. Cambridge: Cambridge University Press, 1981.

Rosenberg, Charles E. "What Is an Epidemic? AIDS in Historical Perspective." Daedalus 118, 2 (1989): 1-17.

Rovello, Gabriele, Adelaide Andriani, Sara Brambilla, Danae Bossi and Michele Augusto Riva. "Oscar-Nominated Movies and the Epidemiology of Tuberculosis in the Past 90 Years." American Journal of Infection Control 46, 9 (2018): 1082.

Roy, Melissa, Nicolas Moreau, Cécile Rousseau, Arnaud Mercier, Andrew Wilson and Laëtitia Atlani-Duault. "Ebola and Localized Blame on Social Media: Analysis of Twitter and Facebook Conversations during the 2014-2015 Ebola Epidemic." Culture, Medicine and Psychiatry 44, 1 (2020): 56-79.

Scheidel, Walter. The Great Leveler: Violence and the History of Inequality from the Stone Age to the Twenty-First Century. Princeton, NJ: Princeton University Press, 2017.

Schell, Heather. "Outburst! A Chilling True Story about Emerging-Virus Narratives and Pandemic Social Change." Configurations 5, 1 (1997): 93-133.

Schweitzer, Dahlia. Going Viral: Zombies, Viruses, and the End of the World. New Brunswick, NJ: Rutgers University Press, 2018.

Serlin, David. "Introduction: Toward a Visual Culture of Public Health." In: David Serlin (ed.), Imagining Illness: Public Health and Visual Culture, pp. xi-xviii. Minneapolis, MN: University of Minnesota Press, 2010.

Slugan, Mario. "Pandemic (Movies): A Pragmatic Analysis of a Nascent Genre." Quarterly Review of Film and Video (2021), early online, https://www.tandfonline.com/doi/abs/10. 1080/10509208.2021.1890975?journalCode=gqrf20.

Snowden, Frank M. "Emerging and Reemerging Diseases: A Historical Perspective." Immunological Reviews 225, 1 (2008): 9-26.

Sontag, Susan. Illness as Metaphor and AIDS and Its Metaphors. New York: Routledge, 2002.

Stein, Eric A. "Colonial Theatres of Proof: Representation and Laughter in 1930s Rockefeller Foundation Hygiene Cinema in Java." Health and History 8, 2 (2006): 14-44.

Tomes, Nancy. "The Making of a Germ Panic, Then and Now." American Journal of Public Health 90, 2 (2000): 191-198.

Tomes, Nancy. "Epidemic Entertainments: Disease and Popular Culture in Early-TwentiethCentury America." American Literary History 14, 4 (2002): 625-652.

Tomes, Nancy. “'Destroyer and Teacher': Managing the Masses during the 1918-1919 Influenza Pandemic.” Public Health Reports 125, 3 (2010): 48-62.

van Bavel, Bas J.P., Daniel R. Curtis, Jessica Dijkman, Matthew Hannaford, Maïka De Keyzer, Eline Van Onacker and Tim Soens. Disasters and History: The Vulnerability of Resilience of Past Societies. Cambridge: Cambridge University Press, 2020.

Vercruysse, Tom. The Dark Ages Imaginary in European Films. Ph.D. Thesis. Katholieke Universiteit Leuven, 2014. 
Vidal Pierre, Myrtille Tibayrenc and Jean-Paul Gonzalez. "Infectious Diseases and Arts." In: Myrtille Tibayrenc (ed.), Encyclopedia of Infectious Diseases: Modern Methodologies, pp. 677-740. Hoboken, NJ: Wiley, 2007.

Wagner, Wolfgang, Nicole Kronberger and Franz Seifert. "Collective Symbolic Coping with New Technology: Knowledge Images and Public Discourse." British Journal of Social Psychology 41, 3 (2002): 323-334.

Wald, Priscilla. Contagious: Cultures, Carriers, and the Outbreak Narrative. Durham, NC: Duke University Press, 2008.

Wald, Priscilla. "Bio Terror: Hybridity in the Biohorror Narrative, or What We Can Learn from Monsters." In: Lincoln Geraghty and Mark Jancovich (eds.), Contagion: Health, Fear, Sovereignty, pp. 99-122. Seattle, WA: University of Washington Press, 2012.

Weingart, Peter. "The Lure of the Mass Media and Its Repercussions on Science." In: Simone Rödder, Martina Franzen and Peter Weingart (eds.), The Sciences' Media Connection: Public Communication and Its Repercussion, pp. 17-32. Dordrecht: Springer, 2012.

Weinstock, Jeffrey. "Virus Culture." Studies in Popular Culture 20, 1 (1997): 83-97.

Wijdicks, Eelco F.M. Cinema, MD: A History of Medicine on Screen. Oxford: Oxford University Press, 2020.

Williams, Rowan. "Plague as Metaphor." In: Jonathan L. Heeney and Sven Friedemann (eds.), Plagues, pp. 196-212. Cambridge: Cambridge University Press, 2017.

Zimmerman, Peta-Anna and Matt Mason. "WhyZombie? Zombie Pop Culture to Improve Infection Prevention and Control Practices.” In: Evie Kendal and Basia Diug (eds.), Teaching Medicine and Medical Ethics Using Popular Culture, pp. 55-70. Cham: Palgrave Macmillan, 2017. 


\section{Societal responses to epidemics Immorality and resistance}

Disaster movies often draw upon images of panic and chaos for entertainment value, and accordingly, we might assume that epidemic-focused or epidemic-related films carry the same characteristics. Indeed, frequently straddling the line between fantasy, science fiction, and horror genres, films addressing themes of disease, infection, and contagion are often linked to broad categories concerning fears over bioterrorism or biohazards, the rise of an undead — often zombie - existence, and an apocalyptic destruction or near destruction of the whole of humanity. These scenarios, one would assume, lend themselves to exciting footage of panicked mobs amidst the complete breakdown of societies. Indeed, disease psychology literature has suggested a close connection between epidemics, fear, and panic (Strong, 1990), and according to Susan Sontag in Illness as Metaphor, related to the "unique" characteristics of infectious diseases themselves (1978). Thus, for example, on the "psychosocial" effects of epidemics, it has been said that the disproportionate degree of fear is connected to the fact that "it is transmitted rapidly and invisibly; historically, it has accounted for major morbidity and mortality; old forms re-emerge and new forms emerge; and both the media and society are often in awe" (Pappas et al., 2009: 743).

It is clear, however, films addressing epidemic diseases often depict more complex societal responses than simply panic and chaos driven by fear. One only needs to point to the plethora of films that have dealt sensitively and with nuance on the topics of HIV and AIDS - addressing issues such as medical ethics, distrust and mistrust in medical information, homophobia, and other forms of discrimination, prejudice, and stigma - either through oral testimony supporting documentary filmmaking such as How to Survive a Plague (David France, 2012), or biographical dramas and docudramas such as And the Band Played On (Roger Spottiswoode, 1993), Philadelphia (Jonathan Demme, 1993), Angels in America (Mike Nichols, 2003), and Yesterday (Darrell James Roodt, 2004), among others. ${ }^{1}$ Other films such as Kids (Larry Clark, 1995), that blurred the lines between fiction and documentary-style reality, used techniques such as "hyper-authenticity" to evoke intense public debate and perhaps even a moral panic_- "a wake-up call to the modern world" according to film critic Janet Maslin when it was released - over the link between HIV and the lives of a group of apathetic and nihilistic New York city youths with daily lives centered around sex, drugs, and violence (Hart, 2007: 118).

DOI: $10.4324 / 9781003261667-2$ 
These nuances and variations in society-disease interactions in cinema do not simply hold for HIV and AIDS only, however, but can also be found in films dealing with fictional representations of other real diseases such as cholera in The Painted Veil, films offering made-up diseases grounded in reality as seen in Contagion, and even in films based around implausible situations such as the zombie infections of Dawn of the Dead (George A. Romero, 1978) or Train to Busan. In this chapter, through performing a meta-review of films drawn from a large database of epidemic-focused and epidemic-related films (see Filmography), we suggest that although societal responses such as panic are often found in certain scenes, the fear behind this panic is rarely associated with features of the disease. Instead, films through cinematic history have shown two kinds of societal responses connected to already-existing fears and concerns.

The first societal response to epidemics that we identify is informed by concern over broader moral failings within society at large, and can lead, on occasion, to more extreme cases of prejudice or scapegoating, if those moral failures are found or are believed to be attributable to a particular social, demographic, or cultural group. This is very much in line with the "outbreak narrative" of Priscilla Wald (2008), where she suggested that the spread of disease depicted in media and popular culture tends to occur within a framework of fear from "native", "mainstream", or "developed" societies towards "marginalized", "deviant", or "underdeveloped" groups. To add to Wald's framework, we also suggest that vice versa, the moral failings of these particular groups - often seen as directly leading to outbreaks of epidemics - tend to be countered and redeemed by the selfless sacrifices of "outsiders", who often are acting as the "white knight".

The second social response to epidemics that we identify is informed by the perceived application of arbitrary or excessive controls or regulations by elites or authorities. Indeed, rather than invoking extraordinary changes to everyday life or complete social breakdowns, in many epidemics-related films we see that disease outbreaks often lead to very focused, deliberate, and coordinated responses such as resistance or unrest by communities and individuals from below-occasionally disruptive or violent - but to paradoxically retain and protect aspects of "normal life" seen to be under threat such as perceived freedoms and liberties and customary time-honored traditions and practices. Significant departures from ordinary social norms are only seen as a form of defense against conditions that prohibit the "return to life as usual" - central to the epidemic disease cycle depicted in Jean Delumeau's classic historical text La Peur en Occident, for example (1978: 161).

These two responses are in line with previous social science models of "epidemic psychology", such as Philip Strong's interpretative framework that emphasizes three elements of fear, moralization, and action/proposed action; although in contrast to previous work which suggests the pull of epidemics is "beyond anyone's immediate control" (1990: 249-251), we place the constellation of societal relations at the center of these responses depicted in cinema. Indeed, films such as von Trier's Epidemic perhaps point towards certain societies' capacity to subconsciously compartmentalize disease. Here, the film's central protagonists are found 
writing a film script based on a plague - entirely oblivious to the contaminating effects of the plague building around them (Bainbridge, 2004: 351)—reflecting an inevitability that there is nothing to do but to live alongside it in casual acceptance of its reality (Cooke, 2009: 152). More recent offerings, such as the German zombie-infection film Rammbock (Marvin Kren, 2010), reflect upon this issue further - not focusing on medical cures and remedies but the capacity of society to endure (Coleclough, 2021).

\section{Societal morality and epidemics in cinema}

Panicked scenes of people fleeing disease-ravaged areas have long been part of cinematic history. In the 1930s film Jezebel, chaotic and violent depictions of nineteenth-century New Orleans - without investment in sanitation or public health infrastructure (Jeter, 1981: 40) - are overlaid with a dramatic, flashing, capitalized "YELLOW FEVER" text across the screen. Officials (largely white police) in the outer lying territories were given authority to shoot anyone (largely the black poor) trying to escape or flee the city (Bibler, 2008: 7, 20). In the Masque of the Red Death (Roger Corman, 1964; readapted by Larry Brand/Jeffrey Delman, 1989) - based on a short story from 1842 by poet and novelist Edgar Allan Poe focusing on a fictional disease with loose parallels to plague - rural villagers become increasingly desperate in their attempts to escape the devastating death, only to have soldiers shoot them down by crossbow. ${ }^{3}$ This panic is almost never associated visually with the already sick or infected, but a disease experience of the "healthy" (Briggs, 2010).

Nevertheless, a more common image seen in films depicting epidemic disease outbreaks is not panic and chaos itself, but instead the major authorities' acceptance of panic as a likely inevitable response from within society, thereby informing their decisions to withhold certain information from the general public or media. In Panic on the Streets, produced not long after the Second World War, the United States Public Health Service is found in broad, if uneasy, agreement with police officials about not notifying the press of a death from pneumonic plague to avoid mass panic in the city of New Orleans (described as a "liberal consensus hegemonic" in Cagle, 2011: 104) — even if the Dr. Reid (Richard Widmark) takes the whole situation far more seriously than the mayor and city officials. Similarly, in a film appearing in exactly the same year (1950), The Killer That Stalked New York - based around the actual threat of smallpox occurring in 1947 in New York - the authorities again try to cover up information. In this case, they run out of the necessary serum to maintain the vaccination program. European films produced in later decades provided the same recurring formula. Thus, in the British film 80,000 Suspects (Val Guest, 1963), the doctor dealing with an outbreak of smallpox in the small provincial town of Bath, in southwest England, explicitly justifies his decision to quarantine with the explanation that it would reduce the chances of public panic. In Morte a Venezia (Luchino Visconti, 1971), a Palme d'Or nominated film based on Thomas Mann's 1912 novel Der Tod in Venedig, the city authorities decide not to inform those on vacation in Venice of 
the problems of cholera in the city, for fear they will frantically leave. Similar to the events of the original book (Wolny, 2019: 16), tourists walk around the city completely oblivious to the dangers involved.

By the 1970s, public health officials and government officials were no longer working in unison, as seen in Panic on the Streets, but the notion of obscuring facts formed part of the film narratives. While medics in the Mexican film El año de la peste (Felipe Cazals, 1979) persistently warn authorities about the likelihood of a disease outbreak occurring in Mexico City-testament to the insalubrious environmental conditions - the political authorities not only stubbornly ignore this, but try to cover it up and obscure damning truths about spread and mortality (Rocco, 2014: 76). In Quiet Killer (Sheldon Larry, 1992), the doctor realizes that her patient has died of plague, but her calls for the authorities to warn New York citizens go unheard, as the mayor of the city envisages widespread panic. We may not actually see scenes of panic and chaos in this film, but the anticipation of these responses guides the decisions of the major protagonists - a response provoked by fear. Many of these features even persist in recent epidemic-related films. In The Bay (Barry Levinson, 2012), for example, the toxicity in the water of a coastal Chesapeake Bay town-leading in turn to a water-borne infection through parasitic isopods - is initially dismissed by the local mayor, again anxious of the panic that would ensue if information got out.

It should be said, however, that many films - across a long cinematic historyhave tried to visualize and analyze some of the root causes of this fear, and in many films, the roots lie in societies' view that the disease itself is a product of a deterioration in social morality. One of the earliest and classic examples of that was the German silent film Die Pest in Florenz (Otto Rippert, 1919), which based itself on the actual outbreak of the Black Death in Florence in the mid-fourteenth century, and portrayed death from plague as an outcome linked to immoral behavior and sexual debauchery. The screenplay was largely based on macabre and gothic elements from the already-mentioned short story from 1842, The Masque of the Red Death, but also was supported by rich documentary material from contemporary observers at the time such as Giovanni Villani (Nuova cronica) and Giovanni Boccaccio (Decameron), who shared the same perceived connection between disease and social depravity. ${ }^{4}$ Indeed, across a long history of plagueand other epidemic outbreaks - premodern societies often viewed these diseases as providential punishments for greed, ostentation, and especially a lack of piety (Schama, 1988). ${ }^{5}$

Other films later came to focus on the concept of the plague as an explicit punishment for wrongdoing and immorality such as The Pied Piper (Jacques Demy, 1972) and The Hour of the Pig (Leslie Megahey, 1993), while other filmmakers such as Paul Verhoeven in Flesh+Blood (1985) attempted to frame the plague more within the blurred lines of moral ambiguity. In one film set in the Middle Ages, Anazapta/Black Plague (Alberto Sciamma, 2002), the appearance of the plague was suggested to be the consequence of a previous episode in the village's murky history where a lord's wife was raped by the villagers. This narrative has strong resonance with popular literature such as Elechi Amadi's 1969 novel 
The Great Ponds, which depicts the 1918-1920 influenza outbreak in colonial Nigeria as a direct consequence of the wrath of the Gods for the kidnapping of a young pregnant woman who was sold into slavery (Fisher, 2012: 178-179). In the Norwegian film Trollsyn (Ola Solum, 1994), set within a rural peasant community in western Norway during the Black Death and based on a medieval oral legend "Jostedalsrypa", one scene shows the physically aggressive inquisition of a woman, yet framed within a broader setting of social decline as a couple are simultaneously seen having sex, while others have taken off their clothes and are found rolling down a grassy hill.

On that same note, it should be said that many of the films connecting plagues with fear and social decline focus especially on forms of intolerance in the form of scapegoating and persecution of women as witches such as Dangerous Beauty (Marshall Herskovitz, 1998), set in sixteenth-century Venice and based on an earlier biography of courtesan Veronica Franco (Rosenthal, 1992), and Season of the Witch (Dominic Sena, 2011), set in the heart of the Holy Roman Empire during the Black Death. These films are grounded within a much longer framework of applying a strict moral lens to female decisions and choices - and the "wrong" ones to the spread of disease - discussed at much further length and detail in the "female spreader" section of Chapter 5. It should be noted, therefore, that films such as Season of the Witch-like other classic films such as Det sjunde inseglet (Ingmar Bergman, 1957) or Monty Python and the Holy Grail (Terry Gilliam/ Terry Jones, 1975), among numerous others - use the Black Death, or even the Middle Ages, anachronistically (Vercruysse, 2013). Witch-hunting in Europe only expanded as a phenomenon in the early modern period, and peaked in the late sixteenth and early seventeenth centuries (Black, 2019: 192). Accordingly, cinema has often visualized epidemic disease within a broader framework of playing on stereotypical views of the medieval period - in line with and entrenching public perception - as being filthy, unhygienic, indecent, intolerant, and unenlightened. Ironically, these are all things that historians of medieval public health have shown to be quite far from reality, and particularly when placed in comparison with conditions seen in later periods (Geltner, 2019; Rawcliffe, 2013).

Other films have used plague - or related conceptions of diseases close to plague - to critique contemporary trends within societies seen as particularly corrosive. Thus, for example, the "White Disease", loosely related to leprosy, depicted in the Czechoslovak Bílá nemoc (Hugo Haas, 1937), and based on a play by Karel Čapek produced in the same year, was likely presented as an indictment upon those swayed by fascist ideologies. Similarly, 昨天今天明天 [Zuotian jintian mingtian/Yesterday, Today, Tomorrow] (Patrick Lung Kong, 1970) —a moralizing Hong Kong picture initially titled The Plague which focused on an infection connected to a rat infestation in the urban slums - drew inspiration from Albert Camus's novel La Peste (1947) concerning an epidemic outbreak in an Algerian coastal town, Oran (Engel, 2020). It was initially banned and later edited due to its stark depiction of class-based conflict with inferences to the 1967 anticolonial riots against the British authorities (Teo, 2000: 103-104; Cunliffe, 2020: 48). The Italian film I promessi sposi-that spawned a number of adaptations 
from the original 1827 historical novel (Mario Bonnard, 1923; Mario Camerini, 1941; Mario Maffei, 1964)_focused on moral themes such as inherent injustices within the framework of the law and religious or spiritual hypocrisies (the 1941 version ran into problems with censorship under Benito Mussolini: Celli and Cottino-Jones, 2007: 33-34). Unsurprisingly, the original text from Alessandro Manzoni on which these films were based also had implicit criticism of the rule of the Austrian Empire. Similarly, in Ken Russell's controversial The Devils (1971), banned in numerous countries for years, we see critical reflection on two issues of sexual repression and abuses of power by elites and institutions, framed through the trial of a priest and accusations made by a group of nuns during a time of plague in the seventeenth century. These situations have also been seen in films about other fictional diseases. In the American film What's So Bad About Feeling Good? (George Seaton, 1968), a virus leads a misanthropic group of BeatnikBohemian dwellers of a New York commune to become both "overly" nice and "conventional". This, in turn, creates economic problems as people stop competing with one another (offering a critique of modern capitalism), but the film also critiques essentialist views on the definition of "normal" and what it means to be happy. The mysterious contagion depicted in Die Hamburger Krankheit (Peter Fleischmann, 1979) reflects upon a society that, when under pressure, is quick to sell out their ideals and morals for their own gain or self-protection.

Of course, it should also be noted that films have not always instrumentalized epidemic disease as a way of challenging authority and the order of things - some have also been used to justify developments. For example, in one of the earliest Korean films from the 1920s, Life's Enemy: Cholera, the persistent threat of disease was used as justification for "modernizing" Japanese colonial authority (Chung, 2014), while in the Chinese film Spring Comes to the Withered Tree, produced during the Great Leap Forward period of Chinese Communist history, only socialist medical advances and collective collaboration can protect a rural village from a deadly recurring disease (schistosomiasis) that afflicts the young female orphan protagonist, Meizi (You Jia) (Qin, 2012: 366). What links both these films, however, is that while revering the "new" society that is being forged, they implicitly criticize the "old" ways based around perceived feudalism, conservatism, and tradition.

The earlier reference to Camus links logically on to the additional point that the connection between social immorality and disease was supported by a similar tradition of films from early cinematic history that played on the visualization of dread; as seen in the highly regarded Swedish-Danish silent film Häxan (Benjamin Christensen, 1922), based on research into the Malleus maleficarum (the 1486 guide for inquisitors) and the Nuremberg Chronicle (a world historical account from 1493 told through biblical paraphrase) (Tortolani, 2020: 27), or the lesserknown Singoalla (Christian-Jaque, 1949), set in fourteenth-century Sweden. These themes of existentialist angst and pessimism over social values - and a reflection on the strength or weakness of human relationships - then became central features of more well-known later films such as Bergman's Det sjunde inseglet, with the famous scenes of the knight (Max von Sydow) playing chess with Death (Bengt 


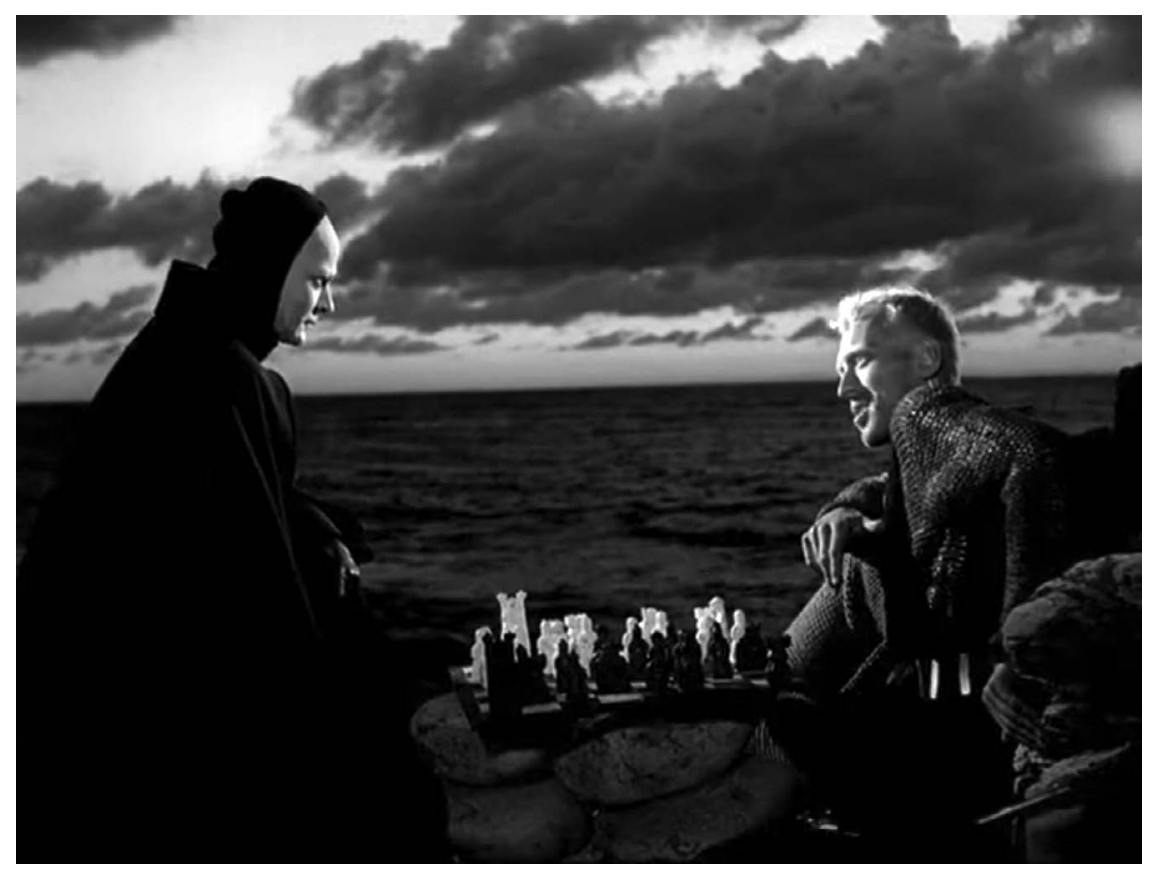

Figure 2.1 Playing chess with "Death" in Det sjunde inseglet (Ingmar Bergman, 1957)

Source: Captured from personal copy.

Ekerot) (see Figure 2.1), but also Epidemic, La Peste (Luis Puenzo, 1992)directly based on Camus - and Black Death (Christopher Smith, 2010). Often fear and social immorality during outbreaks of epidemic disease have been presented as operating parallel to outbreaks of unusual collective behaviors, perhaps drawing inspiration from the cases of "dancing mania" seen in various points and places during the Middle Ages connected to collective consciousness and dread of punitive afflictions (Waller, 2009) - also recently marked in film itself through the short ten-minute Strasbourg 1518 (Jonathan Glazer, 2020). Thus, in the aforementioned Trollsyn, we see mass hysteria among the rural villagers typified by crying and shouting, desperate pious acts, suicides, frantic searching for buboes, and exaggerated and unusual movements, as well as prayer, self-flagellation, and genuflection (Rees, 2003: 403-404). Similarly, in The Masque of the Red Death, we see a type of collective fear over the inevitability of death (Riva et al., 2014: 1753), which is turned into an outlandish and over-the-top form of dance (intended as an absurdist parody of the medieval "concept") (Torres, 2010: 188).

A final characteristic of the links drawn between epidemic disease outbreaks and immorality in cinema can be found in those occasions when concern over societal values is translated into prejudicial views on certain groups within society. This is unsurprising given the numerous avenues for stigmatization 
and blame that have been reconstructed for epidemic outbreaks - in the distant past and modern history, but also in contemporary times. Sometimes this has gone down the lines of ethnicity or religion - the mass persecution of Jews after the Black Death, gathered up and burned alive (Cohn, 2018: 48-51), or more recently suspicions and tensions between Hindus and Muslims regarding the poisoning of water systems during the 1994 plague outbreak in Surat, India (Barrett, 2008: 58). As mentioned, and discussed at length in Chapter 5, this prejudice has fallen down the lines of gender, but in the case of HIV and AIDS from the 1980s onwards, also with extreme discrimination down the lines of sexuality (Kazanjian, 2014), an issue that has been well-documented in film. Moreover, some diseases - especially those connected to viruses - do not respect political and cultural borders, and thus can easily become entangled with concerns over refugees, travelers, and migration concerns (Caduff, 2014). Indeed, in line with the renowned theory of sociologist Ulrich Beck, risk becomes dispersed across borders through processes of modernization, globalization, and individualism (1999). Accordingly, xenophobic incidents have been a central feature of recent social responses to emerging infectious diseases post-2000 - during SARS and COVID-19 (Eichelberger, 2007; Devakumar et al., 2020). ${ }^{6}$ For Ebola, the (unrealized) fear concerning a spread from parts of "undeveloped" Africa to parts of "modern" or "developed" North America or Western Europe, can be framed exactly in line with Wald's "outbreak narrative"- the spread of infection going in one direction only (2008) - and that also highlights a related final component of prejudice down socio-economic lines, explored later in Chapter 6.

It is unsurprising, therefore, that popular culture has often reflected upon moral associations drawn between disease and social and cultural phenomena through metaphors such as corruption, decay, and pollution (Sontag, 1978) - the internal whole threatened by the external other, and an "out group" that are equally seen as intrinsic carriers (Kraut, 1994: 3). This has long been a feature of popular literature in modern history - see, for example, the Sherlock Holmes story, The Giant Rat of Sumatra (not actually penned by Conan Doyle but originally referred to in a throwaway line in The Adventure of the Sussex Vampire, 1924), where Professor Moriarty prepares to import plague to Britain by acquiring infected rats from Southeast Asia (Aberth, 2003: 200). The perceived threat from the East was particularly acute in the late nineteenth and early twentieth century-fueled by "yellow peril" fears (Han, 2016: 75-79) — and we see that most clearly in the novels of American author, Jack London. Although perhaps more renowned for his story of an uncontrollable epidemic of the future in The Scarlet Plague (1912), two years earlier he published a similar story where Western countries tried to arrest the perceived uncontrolled growth of Chinese population by infecting China with a devastating disease (Riva et al., 2014: 1754).

These moral associations were transferred seamlessly to visual culture. Thus, in the very early silent film from 1914, The Temple of Moloch, the wealthy pottery owner, Harrison Pratt (Warren Cook), is the cause of tuberculosis with his terrible factory conditions, but still in the end, emphasis is on the direction of transmission from poor to rich — a poor female laborer eventually infecting Pratt's 
more affluent daughters in his own household. These kinds of films from the early twentieth century foregrounded new societal concerns connected to the "second" Industrial Revolution such as the closer interlinking of public and private spaces (Tomes, 2010: 52). In I promessi sposi, set during the terribly severe 1630 plague in northern Italy, Milan citizens view Renzo (Gino Cervi), the humble village weaver, with suspicion on the basis of his clothes that mark him out as an outsider from the rural uplands - and thus an external agent possibly spreading the plague. In other early films, emphasis is instead directed towards disease conceptualized as a "beautiful seductress" as in the aforementioned Die Pest in Florenz or connected to the actions of a scorned "scarlet woman" as in A Man's Country or Jezebel - a hedonistic life that requires redemption as seen in the figure of Lady Edwina Esketh (Myrna Loy) in The Rains Came.

Just as with the Sherlock Holmes example, early films also tended to Orientalize disease transmission. In Pacific Liner (Lew Landers, 1939), the "Asiatic cholera" that spread on board a ship departing from Shanghai originated with a Chinese stowaway hiding in the lower decks - conforming to three key criteria of being Asian, poor, and migratory. Much of this disease spread image was supported too by perceived exoticism. In What's So Bad About Feeling Good?, for example, the virus originated in a toucan from South America, and similarly, the airborne "Argromoto Flu" depicted in Retreat (Carl Tibbetts, 2011)-incurable, contagious, and with $100 \%$ morbidity - spreads across the whole world also from its origins somewhere in South America. The cholera outbreak in Los Angeles in Contagious (Joe Napolitano, 1997) was connected to contaminated shrimp caught in Colombia - with the choice of disease and location likely timed with increased fears (an "outbreak narrative" even) connected to the reemergence of severe cholera outbreaks in Peru in 1991 (Cueto, 2003). In Variola vera, the origins of the smallpox outbreak are attributed to a Kosovo Albanian Muslim pilgrim, infected at a bazaar in the Middle East - which corresponds roughly to the events of the actual smallpox outbreak in Belgrade in 1972, where a cleric returned to Dakovica in Kosovo after visiting a number of religious sites in Iraq. The film plays on this - the origins of the disease connected to a flute seller, whose mystery and foreboding aura are magnified to the audience by him standing in the shadows with a hood, obscuring his face. Similarly, in A Matter of WHO (Don Chaffey, 1961), an attempted comedic search for the chain of transmission from a potential smallpox sufferer who flies to the UK, the doctor in one scene (Terry-Thomas) brings out a map where the markers signifying potential reservoirs of diseaseplague, cholera, and smallpox — are all plotted in Central and East Asia. In the earlier Surprise Attack (Crown Film Unit, 1951), the infection of a young British girl with smallpox was also said to have been brought back via a ragdoll given by her father who had just returned from East Asia. Despite being produced in 1951, this film is notable for its ending where the doctor predicts the likelihood of global transmission of disease through future expansion of air travel (Weston, 2016: 142).

Although in modern cinema these images have become more nuanced and subtle, many more recent films - perhaps subconsciously - still have continued to 
perpetuate the same direction of disease movement, typically from East to West, and playing on common stereotypes using concepts of othering, exoticism, and Orientalization. In two of the most well-known modern epidemic films, the virus that comes to afflict the United States in Outbreak, modeled on Ebola, originates in Zaire (now the Democratic Republic of Congo) (for the significance of food, war, and jungle imagery in these images: Semmler, 1998), while in Contagion the epidemiological mechanisms fit neatly with Wald's "outbreak narrative" framework as the pathogen is brought into the Western world via an encounter with a chef from Macau. This is placed within a moral story of a negative view of Chinese (over)development encroaching upon natural ecosystems containing wild animals (the disruption of the bat carrying the banana), Chinese pig farming practices, and Chinese culinary hygiene. The preoccupation with filth is seen when Li Fai (Chui Tien You) is seen stumbling through the streets in a feverous state- -with his vision zooming in on crowded and chaotic seafood markets, and completely in line with moralizing criticisms of "wet markets" seen during the COVID-19 outbreak, but also already in the years preceding it (Lynteris, 2016b), and rooted in cultural superiority narratives derived from nineteenth-century European colonialism (Mahr, 2020). Despite this, most of the proactive life-saving decisions in the film are made by westerners - and the only response we see in East Asia is the eventual kidnapping and bargaining of a white epidemiologist, Dr. Orantes (Marion Cotillard), by a Chinese government official, Sun Feng (Chin Han). The same woman seemingly returns to the village where she was kidnapped as the potential savior and "white knight".

This final point links to an as yet undiscussed dimension of Wald's "outbreak narrative": where the "developed" turns "savior" as an "undeveloped" or "traditional" society under threat of an epidemic is heroically protected by outside forces. In The Painted Veil, for example, a 1920s rural village in China is presented as the center of a cholera outbreak - unable to be controlled by local inhabitants or Chinese officials - and is only "rescued" when a British bacteriologist comes along to investigate. In the end he selflessly gives his own life without broader recognition - a concept discussed at further length in Chapter 4 where epidemic-related "heroism" in cinema is problematized. It should also be noted that this direction of paternalistic protection is not merely West to East, however, or solely a "white savior" power fantasy (Jaivin, 2018: 34). For example, in line with growing economic power of China-and investment of economic and cultural capital within Africa - the popular film Wolf Warrior 2, which was based on a similarly popular military novel 弹痕 [Bullet Hole] (Fenwu Yaoji, 2016), favorably presented Chinese attempts to control a fictional disease ("Lamanla"), based on Ebola, in an unmentioned area of Africa: unmentioned because in this film's conceptualization, Africa is "all the same" and merely represents a homogenized form of "underdevelopment".

It should be noted that throughout most of cinematic history-encompassing both older films and more recent ones - there have been surprisingly very few visual images of physical or violent subjugation of easily targeted vulnerable groups or scapegoats during epidemics, with the only clear exceptions being the 
previously mentioned films focusing on those accused of witchcraft and sorcery (usually down gender lines), and more nuanced films dealing with HIV and AIDS, and discrimination against LGBTQ communities, intravenous drug users, and sex workers. This likely reflects the fact that most of the othering that takes place in epidemic-related films is not a direct and active critique or analysis of this phenomenon, but merely reproduces and entrenches these same values-perhaps consciously and willingly in the case of earlier cinema, and perhaps subconsciously and without realizing it in the case of films produced from roughly the 1990s onwards.

There are, of course, always exceptions. An interesting one is a recent Irish horror film, The Cured (David Freyne, 2017), that creatively deals with the issue of social othering towards those people that have been infected with a disease (the so-called "Maze Virus") but have been cured. Here, "the cured" struggle to reintegrate back into society, are shunned by community groups, and have their civil liberties curtailed. One of the suspicions put forward by those "not-yet-infected" is that "the cured" would actively support another outbreak of the disease, since they are resistant. Naturally this prejudicial narrative links up very closely with historical episodes of suspicion of those that were assumed to be resistant-most notoriously seen with persistent perception of innate immunity of West and Central Africans and their descendants in the Americas to yellow fever (Espinosa, 2014). Similar themes of discrimination directed towards those living (in a managed way through drugs) with a disease after an epidemic outbreak were directly addressed in The Returned (Manuel Carballo, 2013). The point of social unrest starts to form when societies begin to realize that there is a finite supply of these drugs. It should be noted, furthermore, that more recent films have tried to give more agency to those infected by a disease-in the British film The Girl with All the Gifts (Colm McCarthy, 2016), for example, the focus of the narrative is on a female protagonist, Melanie, who despite being infected with a parasitic fungus, is recognized for her intelligence, and eventually stands at the end of the film as the "future of society" moving forward.

In general, however, those films that do offer images of physical oppression of blamed targets do not necessarily follow the repressive pattern presented previously, where the strong, the powerful, the wealthy, the authority, or the elite, attack the weak or vulnerable. For example, in Le Hussard sur le toit (Jean-Paul Rappeneau, 1995), set during a cholera outbreak in nineteenth-century Manosque and surroundings in southern France, and based on a 1951 book of the same name by Jean Giono, ${ }^{7}$ the film's protagonist, a privileged Italian nobleman named Angelo (Olivier Martinez), is captured and taken to the authorities by a paranoid mob of ordinary local villagers who accuse him of poisoning the town fountain (see Figure 2.2). Such a scene is of course reminiscent of violence towards perceived elites - medics and political authorities - during outbreaks of cholera in the nineteenth and early twentieth centuries (Cohn, 2018: 204-262), and is a direction of resistance "from below" seen in epidemic-related films that the next section of this chapter now turns to. 


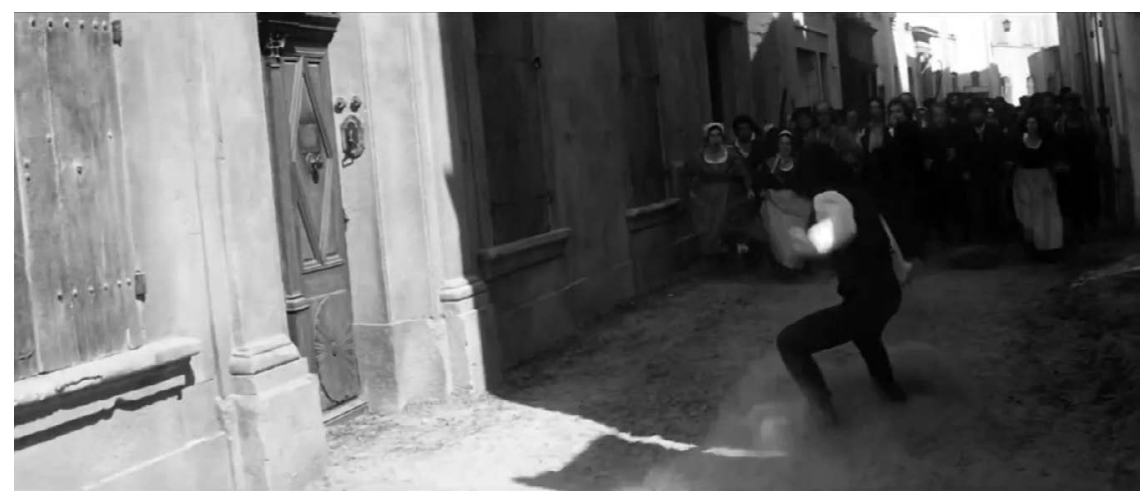

Figure 2.2 The paranoid mob in Le Hussard sur le toit (Jean-Paul Rappeneau, 1995)

Source: Captured from personal copy.

\section{Preserving the ordinary during epidemics in cinema}

Although epidemics, as described in the earlier framework, can create responses indicative of the unraveling of the social fabric, the bonds of society need not be necessarily loosened. Indeed, in this second framework, some films have shown that extreme reactions during epidemics often have a specific purpose-rather than being unfocused panic or chaos - and often paradoxically involve elements of unrest such as resistance to authorities and elites as a way of attempting to return society back to an "ordinary" or "normal" state. Indeed, much emphasis in disease-society literature has tended to be on the Foucauldian aspects of disease management, where sickness becomes an arena where top-down repressive social controls can be enforced (for the original statements: Foucault, 1995 [1975]: 195-200; for a useful overview directly related to disease: McKinlay, 2009). At the heart of this theory, inequitable (and complex) power relations are said to create types of knowledge, discourses, practices, and norms about human bodies (Lupton, 2020). Thus, when applied in less abstract terms, in nineteenth-century India, for example, the classic work of David Arnold once suggested that major epidemic diseases such as smallpox, plague, and cholera were instrumentalized by the colonial authorities to gain control over Indian lives and bodies (1993).

However, also as Arnold, and later others noted (Hodges, 2005), communities rarely have accepted top-down or outsider restriction and coercion passively. Indeed, epidemic diseases can also be a context through which groups from the bottom-up can begin to vent frustrations - perhaps leading to conflict - as a way of protecting freedoms or traditions and customary practices of meaning and value (Curtis, 2020). The validity of this argument has been corroborated with some of the discontent and protests seen during COVID-19-some episodes ending in destruction of private and public property and violence. And accordingly, when we look to films such as the British Doomsday (Neil Marshall, 2008), 
although the context behind the response to the "Reaper Virus" is extreme methods of governmental quarantining, the most significant developments in the film are actually in response to this - in this case creating civil unrest amid a background of economic turmoil. As noted in Chapter 1, by zooming in on the micro scale of individual protagonists and relatable characters across various social and demographic groups, films can often shine new light on this process of disease responses shaped by vertical and horizontal relationships - not just power from above, but the reception of this applied power from below.

This kind of scenario we can, perhaps surprisingly, identify even in early films from before the Second World War-despite moral coding that tended to side with “official authorities". In King Vidor's The Citadel, based on a novel published a year earlier in 1937 by A.J. Cronin, newly qualified and idealistic Dr. Andrew Manson (the Oscar-nominated Robert Donat) is sent to a poor mining village in the South Wales Valleys suffering from outbreaks of tuberculosis as a result of the insalubrious working conditions. Although he attempts to deal with the problems with professionalism and dedication, and is sympathetic to the miners and their associations, his efforts to perform research meet local resistance among the community members - suspicious of this "elite outsider"- - and this comes to a head when they destroy his entire laboratory and working documents, forcing him to move away to London. At the heart of this conflict is a recognition in the original novel of Dr. Cronin that relationships between contracted doctors and mining communities were often sour, but also more broadly framed within a conflict between the "private" medicine of Manson and the local public health institutions already serving the villages (McKibben, 2008: 661, 664). These disputes would have parallels with an earlier film from 1931, Arrowsmith, again based on a novel (penned by Sinclair Lewis in 1925, who later received a Nobel Prize in Literature), where the film and book protagonist, Dr. Martin Arrowsmith (Ronald Colman), is found in heated disagreements with local communities from below and medical institutions from above. As one might expect from films of this era, it is the doctor's struggles that are foregrounded - and the barriers to "progressive" new ideas - rather than the actions or decisions of local communities which are presented as conservative and reactionary.

The capacity for epidemic disease to offer a window of opportunity for pushback by ordinary citizens against arbitrariness and heavy-handedness from authorities - as seen in the already mentioned Mexican film, El año de la peste. While government institutions use a variety of legislation and physical force to repress and control the citizens of Mexico City during the outbreak, we also see different kinds of resistance. Some of this is violent - the throwing of stones, for example, at elite targets, but some is also more passive and more symbolic: the infected hiding away in the wardrobes and cupboards of their houses, preferring to die than fall into the hands of the authorities (Rocco, 2014: 78). Similarly, in the earlier Franco-Mexican production of Les Orgueilleux (Yves Allégret, 1953), discussed in more detail in Chapter 4, a poor man from the docks uses a gun to warn the local doctor that if he hospitalizes his little girl (in the context of a meningitis epidemic), "he'll blow his stomach out", while a riot ensues when the lines of 
communication are cut in an enforced quarantine. In the Polish film Zaraza, produced within a very different filmmaking context, citizens also are found resisting authorities - spitting at police officers, for example — but much of the film tends to show a form of dialogue between authority and citizen (Kunicki, 2021). Questions are asked - "Why are you taking people away in the middle of the night?"but this is met with rational answers from authorities that are accepted calmly. Thus, the extent and magnitude of the pushback varies across filmmaking context.

Nevertheless, similarities can be seen in East Asian cinema. In the Taiwanese film, The Hole, the opening narration reveals that as a result of the ongoing epidemic_labeled as "Taiwan Fever"-the imposition of quarantines and the attempts to move people to temporary housing were enforced via cutting off the water supply and the collection of garbage. The perceived injustice of this situation is revealed by the female narrator-also a resident of the dilapidated apartments - who points to the fact the epidemic is a product of long-term neglect:

This is not fair to the people who live here. If the epidemic is really prevailing, they should have done something a long time ago ... but they didn't do a thing about it - they didn't try to protect us. Now look. The disease is wide-spread and everyone is sick. ... Some people have lived here for generations . . . they can't make us leave our homes.

This forms the background to social resistance from below. The two main protagonists of the film refuse to move out, with the woman exclaiming "why should I cooperate with them?". She then threatens to simply dump her garbage anywhere - in one scene bagging it up and chucking it out the window of her apartment. The dystopian vision presented in this film already partially took its cue from earlier Chinese-language pictures such as the 1970's Yesterday, Today, Tomorrow, which, even in its severely edited version (reduced from a running time of 120 minutes to 77 minutes, with the removal of explicit scenes of rioting against authorities: Cunliffe, 2020: 47, 62), surprisingly kept in the scenes of ordinary people stabbing a police guard who was stringently enforcing a quarantine. In this film, it is the ordinary members of civil society that are credited with saving Hong Kong from a plague, rather than members of the colonial government (Cunliffe, 2020: 59).

If we fast-forward to more recent times, more nuanced views about how societies respond to epidemics can be found in films, especially showing how extreme reactions tend to not be intrinsically associated with the disease itself but rather as a way of dealing with top-down repression impinging on freedoms and liberties. Contagion is one of the most prominent examples of a film that deals with social movements from below, in the process criticizing perceived trends towards societal greed and self-interest. Indeed, most unrest seen in the film stems from a tension between medical authorities' advised procedures - including forcible isolation and quarantine methods - and contemporary demands and needs for the maintenance of ordinary patterns of social networking and communication. Of course, this has parallels throughout history. For example, recurring plague 
outbreaks rarely were enough to put a stop to religious rituals of communal significance such as the Janāza blessing in the Middle East (Borsch and Sabraa, 2017). And when we look again to cinema, in films such as The Horse Thief, we see that recurring disease outbreaks in the steppe or grasslands of Tibet were rarely able to prevent people from continuing their daily functions within this pastoral society - perhaps only stopping to pray for the disease to cease. In the recent Kazakh film Chuma v aule Karatas (Adilkhan Yerzhanov, 2016), a new mayor from outside is alarmed to find out that a mysterious disease is infecting the villagers, and yet the local community downplays the significance of this (dismissing it as a "flu"), continuing with their ordinary routines within a broader context of local corruption (Isaacs, 2018: 219).

It should be emphasized then that most unrest we see in recent films-from Blindness to 감기 [Gamgi/Flu] (Kim Sung-su, 2013)—remains little connected to emotions stemming from the disease itself but to perceived arbitrary and ruthless actions of elites and authorities. Indeed, in Blindness, and discussed at further length in Chapters 3 and 5, we see scenes in which resources such as food begin to be distributed inequitably, and men begin to exploit their positions by withholding food in exchange for other resources, including coercing women into sex with the threat of violence. Most of the physical confrontation stems from hostilities between those subject to quarantines and those managing the confined environments - either formally as guards or informally in internal hierarchies between wards. In Flu, a Korean film based around recent experiences with SARS and influenza by employing a fictional disease with parallels to the strain of avian influenza $\mathrm{A}(\mathrm{H} 5 \mathrm{~N} 1)$ virus, we see on the one hand many very cliched scenes of frenzied breakdown - the frantic phone calls as the first details of the disease emerge, the rush to exit the city, and the fight for resources and the looting of a supermarket. Yet on the other hand, we also see much more focused forms of unrest directed at particular social groups, especially in the process of implementing quarantines. Indeed, when infected citizens are forcibly moved to temporary camps, some elements of compassion or cohesion develop among camp residents, yet the most violent reactions both come from and are directed toward authorities managing the site in an arbitrary and heavy-handed manner.

Aside from freedoms and liberties, other films have highlighted how societies sometimes move toward unrest - through either passive resistance to authorities or physical violence - as a response to perceived infringements on customary and traditional practices that have occurred during an epidemic outbreak, and yet hold central symbolic importance in normal times. One of the clearest demonstrations of this response appears in the 2006 readaptation of The Painted Veil, already mentioned, which follows a British bacteriologist (Edward Norton) working to prevent the spread of cholera in a small village in rural China in the 1920s, set within a broader context of the rise of nationalist sentiment and anti-colonial tensions. In this film we see no signs of fear or panic from the local villagers, despite many deaths within the community, and the first time that we see anger and resentment is when the "outsider" doctor tries to move bodies from the cemetery to avoid infecting the water. The decision to remove all corpses and bury 
them immediately - using soldiers to physically enforce this - raises further fury because the villagers expect a certain period to elapse while the bodies are laid out in their homes before burial. Although we must be aware of the potential effects of the Orientalist or exoticizing imagination when considering a film such as The Painted Veil, social and medical history does at least corroborate this kind of image. For example, it has been argued that in rural China during the 1920s and 1930s, elite medical reformers' disregard for village internal politics and power dynamics limited the effectiveness of their public health prevention policies, as locals continued the same routines (Merkel-Hess, 2016). In the writings of novelist Xiao Hong, such as The Field of Life and Death (1935/2002) set in a rural community near Harbin, in northeast China, frequent reference is made to the rejection of Western (and Russian) medical aid, ${ }^{8}$ where in one line a woman exclaims: "They give shots even to little babies. You see, I've brought my child with me. I won't let them stick a needle in him. I'd rather see him die first!" (Gansa, 2006: 163).

Nevertheless, films can also provide cautionary warnings about the dangers of leaning too far in this direction. In the German film Schlafkrankheit (Ulrich Köhler, 2011), winner of a Silver Bear award at the Berlin Film Festival for best director, a Dutch doctor is found working in Cameroon during a sleeping sickness outbreak - and is caught between the demands of his own Western family and the networks and family he starts to build in West Africa. Small everyday observations allow a window into the postcolonial relationship between Europe and Africa. On the one hand a big question is asked about how we can affect change in the context of an epidemic and development aid, when only viewing challenges from the perspective of the outsider. Yet on the other hand, this is further complicated as the total assimilation of the central protagonist Dr. Ebbo Veltman (Pierre Bokma) into the networks, practices, and minds of the local villagers is paradoxically partially forged through the exertion of status and autonomy. In the end, an absence of social distance of medic and community brings with it ensuing problems for Dr. Veltman, who finds himself trapped within contradictory forces of assistance and destruction.

\section{Conclusion}

In this chapter, it has been argued, using many film examples across time and place, that not only can societal responses to epidemics take very different courses, but the factors driving these responses do not come out of nowhere. Instead, they are informed by developments already happening or existing within societies. In the first case, the prejudicial identification of targeted groups during epidemics - those that might be implicated or blamed in some way - is founded upon a pre-existing discord or a dissatisfaction with the "amoral" path that society has followed. In the second case, the resistance and unrest that epidemics sometimes produce - often in response to arbitrary or excessive social controls impeding freedoms or customs - is built upon pre-existing antagonism shaped by widening gaps between elites and experts, between insiders and outsiders, and 
between those with access to resources and knowledge and those whose access is restricted.

The discussion through the cinematic lens brings into focus the, perhaps paradoxical, relationship between elements of societal resilience and vulnerability during epidemic disease outbreaks. Existing practices and structures are often difficult to break down - even under the weight of pressure of epidemic mortality and associated social controls from above-representing forms of resilience in formal institutionalized or informal customary practice. Yet the movements towards resilient preservation of the ordinary often stems from threats from above that can disproportionately hinder and victimize certain members within societies and communities-representing the underlying layers of societal vulnerability.

In Chapter 3, this line of argumentation is further elaborated upon by zooming in with more detail on three post-2000 films that are can provide extra insights: The Painted Veil, Blindness, and Contagion. Here we suggest that the kinds of responses to epidemics already discussed in this chapter are closely linked to different levels of distrust - which are not shaped by societal experiences of diseases, but founded upon pre-existing inequalities down economic, gender, and racial lines. However, we also note that the direction is not all one way. While victimization of targeted groups or unrest from below are revealing of distrust on some levels, these films also show that new lines of cohesion can be fostered by solidity of trust — often performed horizontally rather than vertically.

\section{Notes}

1 "Sensitively" and "nuance" are relative terms that do not mean, however, that inaccuracies and falsehoods have not been present in HIV and AIDS-related films (de Lacerda, 2006).

2 This notion of sacrifice by an "outsider" has long roots, also in literature: see the grisly death of the "saintly" Tarrou in Albert Camus's La Peste (1947), passing away just hours before the quarantine lifts from the city of Oran (Engel, 2020: 76).

3 Although the identity of the disease on which the Red Death is based is disputed (Sartin, 2019: 44).

4 A contemporary comedic take on the same source material-with an emphasis on debauchery — was directed by David Leland in 2007 under the interchanging titles Medieval Pie and Virgin Territory.

5 Though interacting with miasma theories of disease transmission and spread, where sickness was connected to corrupted airs and vapors connected to dampness, darkness, or odors (Rawcliffe and Weeda, 2019).

6 See all the list of xenophobic and racist incidents listed for COVID-19 at https:// en.wikipedia.org/wiki/List_of_incidents_of_xenophobia_and_racism_related_to_the COVID-19_pandemic.

7 Although the worst phases of the cholera outbreak, such as at the village of Omergues ravaged with sickness, do not appear until much later in the film when compared to the original book (Cauville, 2004: 87).

8 Although loose reference to the scourge of plague, cholera, and tuberculosis epidemics is made in the recent biopic of Xiao Hong's life 黄金时代 [Huangjin shidai/The Golden Era] (Ann Hui, 2014), it is not particularly developed. 


\section{Societal responses to epidemics}

\section{References}

Aberth, John. "Welcome to the Apocalypse: Black Death Films." In: John Aberth (ed.), A Knight at the Movies: Medieval History on Film, pp. 197-254. New York: Routledge, 2003.

Arnold, David. Colonizing the Body: State Medicine and Epidemic Disease in NineteenthCentury India. Berkeley, CA: University of California Press, 1993.

Bainbridge, Caroline. "Making Waves: Trauma and Ethics in the Work of Lars von Trier." Journal for Cultural Research 8, 3 (2004): 353-370.

Barrett, Ron. "The 1994 Plague in Western India: Human Ecology and the Risks of Misattribution.” In: Anne L. Clunan, Peter R. Lavoy and Susan B. Martin (eds.), Terrorism, War or Disease? Unraveling the Use of Biological Weapons, pp. 49-71. Stanford, CA: Stanford University Press, 2008.

Beck, Ulrich. World Risk Society. Malden, MA: Polity Press, 1999.

Bibler, Michael P. “Always the Tragic Jezebel: New Orleans, Katrina, and the Layered Discourse of a Doomed Southern City." Southern Cultures 14, 2 (2008): 6-27.

Black, Winston. The Middle Ages: Facts and Fictions. Santa Barbara, CA: ABC-CLIO, 2019.

Borsch, Stuart and Tarek Sabraa. "Refugees of the Black Death: Quantifying Rural Migration for Plague and Other Environmental Disasters." Annales de Démographie Historique 134, 2 (2017): 63-93.

Briggs, Charles. "Pressing Plagues: On the Mediated Communicability of Virtual Epidemics.” In: D. Ann Herring and Alan C. Swedlund (eds.), Plagues and Epidemics: Infected Spaces Past and Present, pp. 39-59. Oxford: Berg, 2010.

Caduff, Carlo. "On the Verge of Death: Visions of Biological Vulnerability." Annual Review of Anthropology 43 (2014): 105-121.

Cagle, Chris. "The Postwar Cinematic South: Realism and the Politics of Liberal Consensus." In: Deborah Barker and Kathrun McKee (eds.), American Cinema and the Southern Imaginary, pp. 104-121. Athens, GE: University of Georgia Press, 2011.

Cauville, Joëlle. "Le Cinéma Impur: Rappeneau et l'adaptation cinématographique du roman de Jean Giono: Le Hussard sur le toit." Dalhousie French Studies 69 (2004): 83-90.

Celli, Carlo and Marga Cottino-Jones. A New Guide to Italian Cinema. Basingstoke: Palgrave Macmillan, 2007.

Chung, Steven. Split Screen Korea: Shin Sang-ok and Postwar Cinema. Minneapolis, MN: University of Minnesota Press, 2014.

Cohn, Samuel Kline. Epidemics: Hate and Compassion from the Plague of Athens to AIDS. Oxford: Oxford University Press, 2018.

Coleclough, Sharon. "Endure, Not Cure: Rammbock and Pandemic Experience." Apparatus: Film, Media and Digital Cultures in Central and Eastern Europe 12 (2021), http:// dx.doi.org/10.17892/app.2021.00012.251.

Cooke, Jennifer. Legacies of Plague in Literature, Theory and Film. Basingstoke: Palgrave Macmillan, 2009.

Cueto, Marco. "Stigma and Blame during an Epidemic: Cholera in Peru, 1991." In: Diego Armus (ed.), Disease in the History of Modern Latin America: From Malaria to AIDS, pp. 268-289. Durham, NC: Duke University Press, 2003.

Cunliffe, Tom. "Lung Kong's Yesterday, Today, Tomorrow: The 1967 Riots and the Politics of Cultural Production in the Hong Kong Film Industry." Screen 61, 1 (2020): 47-74.

Curtis, Daniel R. "Preserving the Ordinary: Social Resistance during Second Pandemic Plagues in the Low Countries." In: Christopher Gerrard, Paolo Forlin and Peter Brown 
(eds.), Waiting for the Ends of the World: Perceptions of Disaster and Risk in Medieval Europe, vol. 43, pp. 280-297. London: Routledge, 2020.

Delumeau, Jean. La Peur en Occident (XIVe-XVIIIe siècles). Une cité assiégée. Paris: Fayard, 1978.

Devakumar, Delan, Geordan Shannon, Sunil S. Bhopal and Ibrahim Abubakar. "Racism and Discrimination in COVID-19 Responses.” The Lancet 395, 10231 (2020): 1194.

Eichelberger, Laura. "SARS and New York's Chinatown: The Politics of Risk and Blame During an Epidemic of Fear.” Social Science and Medicine 65, 6 (2007): 1284-1295.

Engel, Amir. "Hope, Despair, and Justice in Postwar European Culture: Bicycle Thieves, the Plague, and the Man Outside as Case Studies." Comparative Literature 72, 1 (2020): 68-82.

Espinosa, Mariola. "The Question of Racial Immunity to Yellow Fever in History and Historiography.” Social Science History 38, 3-4 (2014): 437-453.

Fisher, Jane Elizabeth. Envisioning Disease, Gender and War: Women's Narratives of the 1918 Influenza Pandemic. New York: Palgrave Macmillan, 2012.

Foucault, Michel. Discipline and Punish: The Birth of the Prison. New York: Vintage Books, 1995 [1975].

Gansa, Mark. "The Epidemic of Pneumonic Plague in Manchuria 1910-1911." Past and Present 190 (2006): 147-183.

Geltner, Guy. Roads to Health: Infrastructure and Urban Wellbeing in Later Medieval Italy. Philadelphia, PA: University of Pennsylvania Press, 2019.

Han, Qijun. The Cinematic Representation of the Chinese American Family. Cambridge: Cambridge Scholars Publishing, 2016.

Hart, Kylo-Patrick R. "The Trouble with Kids: Harmful Representations of Adolescents and AIDS in a Popular Teen Film.” In: Kylo-Patrick R. Hart (ed.), Mediated Deviance and Social Otherness: Interrogating Influential Representations, pp. 114-125. Cambridge: Cambridge Scholars Publishing, 2007.

Hodges, Sarah. "'Looting' the Lock Hospital in Colonial Madras during the Famine Years of the 1870s." Social History of Medicine 18, 3 (2005): 379-398.

Hong, Xiao. The Field of Life and Death and Tales of Hulan River, trans. Howard Goldblatt. Boston, MA: Cheng \& Tsui Company, 2002.

Isaacs, Rico. Film and Identity in Kazakhstan: Soviet and Post-Soviet Culture in Central Asia. London: Bloomsbury, 2018.

Jaivin, Linda. "Saviours and Slackers." In: Jane Golley and Linda Jaivin (eds.), Prosperity, pp. 32-37. Acton, AUS: ANU Press, 2018.

Jeter, Ida. "Jezebel and the Emergence of the Hollywood Tradition of a Decadent South." Southern Quarterly 19, 3-4 (1981): 31-46.

Kazanjian, Powel. "The AIDS Pandemic in Historic Perspective." Journal of the History of Medicine and Allied Sciences 69, 3 (2014): 351-382.

Kraut, Alan M. Silent/Travelers: Germs, Genes, and the "Immigrant Menace". Baltimore, MD: John Hopkins University Press, 1994.

Kunicki, Mikolaj. “"Medical Doctors Rule the City': Roman Załuski’s Zaraza/The Epidemic and the 1963 Smallpox Outbreak in Wrocław." Apparatus: Film, Media and Digital Cultures in Central and Eastern Europe 12 (2021), http://dx.doi.org/10.17892/app.2021.00012.253.

Lacerda, António Pais de. "Cinema as an Historical Document: AIDS in 25 Years of Cinema." Journal of Medicine and Movies 2 (2006): 102-113.

Lupton, Deborah. "Contextualising COVID-19: Sociocultural Perspectives on Contagion." In: Deborah Lupton and K. Willis (eds.), The Coronavirus Crisis: Social Perspectives, pp. 1-11. London: Routledge, 2020. 
Lynteris, Christos. “The Prophetic Faculty of Epidemic Photography: Chinese Wet Markets and the Imagination of the Next Pandemic." Visual Anthropology 29, 2 (2016b): $118-132$.

Mahr, Dana. "The Cultural Construction of the 'Bizzare': Disentangling Sinophobic Language in Media and Science During the COVID-19 Epidemic." Boasblogs, April 24, 2020, https://boasblogs.org/witnessingcorona/the-cultural-construction-of-the-bizzare/.

McKibben, Ross. "Politics and the Medical Hero: A.J. Cronin's The Citadel." English Historical Review 123, 502 (2008): 651-678.

McKinlay, Alan. "Foucault, Plague, Defoe." Culture and Organization 15, 2 (2009): 167-184.

Merkel-Hess, Kate. "The Public Health of Village Private Life: Reform and Resistance in Early Twentieth Century Rural China.” Journal of Social History 49, 4 (2016): 881-903.

Pappas, Georgios, I.J. Kiriaze, P. Giannakis and M.E. Falagas. "Psychosocial Consequences of Infectious Diseases." Clinical Microbiology and Infection 15, 8 (2009): 743-747.

Qin, Liyan. "The Intertwinement of Chinese Film and Literature: Choices and Strategies in Adaptations.” In: Yingjin Zhang (ed.), A Companion to Chinese Cinema, pp. 361-377. Chichester: Blackwell, 2012.

Rawcliffe, Carole. Urban Bodies: Communal Health in Late Medieval English Towns and Cities. Woodbridge: The Boydell Press, 2013.

Rawcliffe, Carole and Claire Weeda, eds. Policing the Urban Environment in Premodern Europe. Amsterdam: Amsterdam University Press, 2019.

Rees, Ellen. "Dreaming of the Medieval in 'Kristin Lavransdatter' and 'Trollsyn'." Scandinavian Studies 75, 3 (2003): 399-416.

Riva, Michele Augusto, Marta Benedetti and Giancarlo Cesana. "Pandemic Fear and Literature: Observations from Jack London's The Scarlet Plague.” Emerging Infectious Diseases 20, 10 (2014): 1753-1757.

Rocco, Alessandro. Gabriel Garcia Márquez and the Cinema: Life and Works. Woodbridge: Tamesis, 2014.

Rosenthal, Margaret F. The Honest Courtesan: Veronica Franco, Citizen and Writer in Sixteenth-Century Venice. Chicago, IL: University of Chicago Press, 1992.

Sartin, Jeffrey S. "Contagious Horror: Infectious Themes in Fiction and Film." Clinical Medicine and Research 17, 1-2 (2019): 41-46.

Schama, Simon. The Embarrassment of Riches: An Interpretation of Dutch Culture in the Golden Age. Berkeley, CA: University of California Press, 1988.

Semmler, Iliana Alexandra. "Ebola Goes Pop: The Filovirus from Literature into Film." Literature and Medicine 17, 1 (1998): 149-174.

Sontag, Susan. Illness as Metaphor. New York: Doubleday, 1978.

Strong Philip. "Epidemic Psychology: A Model." Sociology of Health and Illness 12, 3 (1990): 249-259.

Teo, Stephen. "The 1970s: Movement and Transition." In: Poshek Fu and David Dessler (eds.), The Cinema of Hong Kong: History, Arts, Identity, pp. 90-110. Cambridge: Cambridge University Press, 2000.

Tomes, Nancy. “'Destroyer and Teacher': Managing the Masses during the 1918-1919 Influenza Pandemic.” Public Health Reports 125, 3 (2010): 48-62.

Torres, Mário Jorge. "The Phosphorescence of Edgar Allan Poe on Film: Roger Corman's 'The Masque of the Red Death'." The Edgar Allan Poe Review 11, 1 (2010): 182-191.

Tortolani, Erica. "Troubling Portrayals: Benjamin Christensen's Häxan (1922), Documentary Form, and the Question of Histor(iography)." Journal of Historical Fictions 3, 1 (2020): 24-41. 
Vercruysse, Tom. "The American Dark Ages and the Terrorist Witch in Season of the Witch." CINEJ Cinema Journal 2, 2 (2013): 52-65.

Wald, Priscilla. Contagious: Cultures, Carriers, and the Outbreak Narrative. Durham, NC: Duke University Press, 2008.

Waller, John. "A Forgotten Plague: Making Sense of Dancing Mania." The Lancet 373, 9664 (2009): 624-625.

Weston, Kathryn M. "Killing the Speckled Monster: Riots, Resistance, and Reward in the Story of Smallpox Vaccination." Health and History 18, 2 (2016): 138-144.

Wolny, Ryszard W. "Travel and Disease in Thomas Mann's Death in Venice." European Journal of Language and Literature Studies 5, 2 (2019): 13-18. 


\section{Suspicious minds \\ Cinematic depiction of distrust during epidemics}

In Chapter 2, we revealed how films can offer a window into differing kinds of societal responses to epidemics - one being a form of moralizing discourse looking inward within a community or society, and the other based on resistance to perceived impositions "from above" or "outside". Indeed, while many scholars across social science and medical humanities disciplines have focused on the "Foucauldian" forces from above - elites or authorities, who have throughout history used epidemic disease outbreaks as a form of "biopower" for implementing oppressive social regulations and restrictions (McKinlay, 2009: 169) - it is clear that societies and communities throughout history and even today have not accepted these impositions or restrictions passively or without dissent or disorder (Curtis, 2020). Furthermore, this dissent or disorder has sometimes passed under the radar of scholars focusing on just the written record and "texts": a view from Dwight Conquergood within "Performance Studies" suggests that the "oppressed everywhere must watch their backs, cover their tracks, suck up their feelings, and veil their meanings . . . subversive meanings and utopian yearnings can be sheltered and shielded from surveillance" (2002: 148).

Implementation of quarantines and isolation have often been contested grounds, communities have disregarded regulations that infringed upon social networking, and attempts to intervene or depart from customary practices such as burials or funerals have often invoked resentment and furious anger (Moran, 2017; Kutalek et al., 2015). During the cholera outbreaks in the aftermath of the 2010 earthquake in Haiti, "outside interests" such as UN workers were blamed as the source or the spreaders of the disease - subverting the direction of the commonly cited "outbreak narrative" from "underdeveloped" to "developed". Outbreaks of Ebola in various parts of Western Africa from 2014 onwards led to difficulties in bridging the gap between the interventions from outside authorities and afflicted local communities. Indeed, people working to stop the disease from spreading, treat the infected, or simply provide information, have been targeted. In November 2019 a Congolese journalist was killed in his home for reporting on the virus (Anon., 2019a), while later that month the World Health Organization (WHO) and other aid groups began to evacuate workers in the context of a violent siege that led to the death of a vaccination worker alongside others (Maxmen, 2019).

DOI: $10.4324 / 9781003261667-3$ 
One key factor that appears to be crucial in leading to the rejection of perceived impositions from above or outside the society during epidemics is trust - or rather distrust (Anon., 2019b). Put simply, communities that are afflicted by an epidemic outbreak are not always convinced that the course of action presented to them by authorities or elites is favorable, and this distrust likely has its roots in a variety of factors - communication failures, lack of cultural sensitivity on the part of outside agencies, pre-existing unstable and strained relations between local communities, legacies of colonialism, failures of local governments, and a lack of understanding of the economic implications that decisions such as quarantines can have-particularly for the poor and vulnerable (Cohn and Kutalek, 2016; Calain and Poncin, 2015). So, for example, recent survey evidence taken from the 2014-2015 Ebola outbreak in Liberia showed that respondents who expressed low trust in the government were much less likely to take protective precautions in their homes, or to abide by government-mandated social distancing mechanisms designed to contain the spread of the virus (Blair et al., 2017; also, on the effects of socio-political arrangements: Wilkinson and Fairhead, 2017). Other work using similar survey methods during an Ebola outbreak found that trust was more likely to be fostered when responders - health workers, clinicians, governments officials, and drivers - used more open, transparent, and reflexive communication methods (Ryan et al., 2019).

Accordingly, communication is important, and in particular, the media play a significant part in establishing trust during or in anticipation of epidemics (Gesser-Edelsburg, 2019). So, for example, it has been noted very recently how the media has perpetuated several misguided anxieties over how people can be infected with Ebola and how the disease transmits and spreads (Millard, 2015; Blakey et al., 2015). The same issue has been magnified even further in previous media representations of the transmission of HIV and AIDS - creating ill-conceived views on disease transmission, moralizing over perceived "risky" behavior patterns, and stereotyped associations of the disease with particular people down the lines of race, sexuality, or socio-economic status (Sinha and Parmet, 2016; Hood, 2011; Khan, 2014). This has been framed by some as a case of the media acting as a source of "moral panic" (Gilman, 2010; Muzzatti, 2005), which links up with renowned sociologist, Ulrich Beck's, view that a characteristic of modernity is an increased awareness of societies' own potential for self-destruction (1992). Furthermore, as explained in the introduction to Chapter 1, other forms of communicative popular culture, such as fictional novels, television shows, and films, can also influence people's trust-providing educational messages and reinforcing values, ideas, and beliefs about how diseases transmit and spread, but also how to feel and how to react during epidemics: that is to say create some expectations about the kinds of societal responses that could potentially occur (Kendal, 2021). Trust and distrust, then, can work through two interacting criteria. Films about epidemics can directly affect audiences' levels of trust in institutions, authorities, and individuals, and moreover, films can use narratives and characters to unpack and reflect upon trust and distrust in epidemic scenarios as cultural and artistic products, particularly by 
addressing hierarchical and horizontal relationships through protagonists and supporting characters.

Accordingly, in Chapter 3 we temporarily leave our broader epidemicsrelated film database behind, and instead zoom in on a close analysis of three films that center around epidemic diseases-Contagion, Blindness, and The Painted Veil - in order to highlight three categories of distrust that have recently been identified and conceptualized in broader medical humanities discussions regarding trust and health. The reason for zooming in on these three films is that they first present epidemics in a realistic or semi-realistic way, rather than overly fantastical or implausible, and have been widely watched: information from IMDb showing that they cumulatively grossed worldwide box-office figures of $\$ 135,458,097, \$ 19,844,979$, and $\$ 26,522,838$ respectively. ${ }^{1}$ Films such as Contagion, furthermore, have had renewed interest in the context of the COVID-19 pandemic.

We categorize trust into three dimensions: (a) institutional trust, (b) social trust, and (c) interpersonal trust - informed by pre-existing frameworks dealing with trust in public health contexts (Brownlie, 2008: 20-21). First, by institutional trust we focus on societies' hierarchical relationships developed with perceived or real elites and authorities, which comes down to people's trust placed in medical and expert information and trust placed in governmental authorities. Second, by social trust we focus on the relationships developed between ordinary citizens themselves as members of communities, and furthermore, trust between members of communities or "insiders" and those seen to be "outsiders" to the communities in question. Third, by interpersonal trust we focus on the micro scale of individual relationships between people within households, families, and friendship networks. Institutional trust, therefore, refers to vertical relationships between those with unequal source of power, whereas the other two forms of trust refer to horizontal relationships - although still not always equal, it should be noted. Interpersonal trust remains largely between kin members, friends, or close neighbors, whereas social trust refers more to civic society, collective institutions, and broader networks beyond the family or friends.

Overall, our analysis of the narratives and characters within these three films establishes and supports two arguments. First, while certain aspects of trust are badly diminished during epidemic disease outbreaks in these films - such as at the institutional level between communities and authorities or elites - this is also often found mediated or negotiated, perhaps even compensated for, by heightened solidity of trust at the social level, within or between communities. However, we also note that this collectivity is often selective with regard to who is considered an "insider" and "outsider", as the lines of demarcation become much sharper. As Judith Butler noted, "Precarity exposes our sociality, the fragile and necessary dimension of our interdependency" (2015: 119), but we assert that the direction in which this sociality moves is not inevitable. Accordingly, our second argument, related to the first, is that epidemics, by interacting with pre-existing structural inequalities within society-based on race, gender, or wealth — create mixed outcomes of cohesion and discord, tolerance and prejudice that push some 
social groups to the outside, and in the process, highlight the complexities of the epidemic-trust-society relationship.

\section{Blindness (Fernando Meirelles, 2008)}

Blindness is a 2008 English-language film adaptation of a Portuguese novel Ensaio sobre a ceguira (José Saramago, 1995), about an indistinguishable society (we are not given location specifics, although it was shot in São Paolo and Toronto: Rueda, 2015: 12) dealing with a case of epidemic blindness. At the beginning of the film, a Japanese man (Yūsuke Iseya) suddenly goes blind in his car at an intersection, his field of vision turning white. Although initially receiving little aid, he is eventually helped by someone who drives him home-only to later steal his car. When his wife comes back, he is taken to an ophthalmologist (Mark Ruffalo), who cannot determine the exact causes of this problem. Directly the next day, the doctor himself also goes blind - and given that we see around the city many other citizens also going blind - we learn that this is a contagious disease. As the numbers of afflicted rise, this becomes a serious epidemic - and one where the government responds by enforcing isolation for the blind into an old derelict abandoned asylum. We also learn that not everybody contracts the disease - the wife of the ophthalmologist (Julianne Moore) retains her vision, but ends up in the facility to protect her husband-keeping her sight a secret from everyone.

In the asylum, a number of other characters also enter - the Japanese couple, the thief, a sex worker, a young boy, an old man with an eye patch and a transistor radio, and many other patients of the doctor. By this time, the epidemic has become a global pandemic, and now given the name the "white sickness" (mal branco in the literary text) on account of the vision of the afflicted turning white - an "impenetrable whiteness" that proved one of the main representational difficulties in adapting from literature to screen (Rueda, 2015: 13). Conditions deteriorate in the camp due to lack of facilities and lack of supporting staff, leading to declines in hygiene and health. Lack of resources and food, however, ends up escalating into new lines of conflict - soldiers who guard the facility become hostile, but also resentment appears between the wards themselves. One ward with access to weaponry ends up threatening the others into submission by taking control of the food supplies - demanding first the valuable goods from other wards, and then coercing sex from women. During a rape, one woman is killed, and this leads to a full-on conflict. Out of the chaos of a burning building, a number of the infected manage to escape - aided by the fact that the guards had already abandoned their posts, falling blind themselves - only to find that outside society was in a similar state of collapse. Upon securing food, the sighted wife of the doctor invites their family to their apartment, where they attempt to establish a safe, mutually supportive residence. At the end some of the characters begin to regain their sight - some celebrate, although for others this is seen as a mixed blessing as it means a return to the "old society" of entrenched inequalities and vulnerabilities. Indeed, the epidemic blindness can be seen as an allegorical reference to society's failure to observe the dysfunction inherent within contemporary 
life, and the return to vision does not necessarily mean the "sickness" has been truly overcome, but instead remains dormant and in waiting-like the pathogen (Donohue, 2017: 81).

In Blindness, we see the three kinds of distrust played out across the course of the film. The breakdown in trust in the decisions and actions of elites and authorities is clear-establishing itself as a form of institutional distrust. It is perhaps not an accident that the filmmaker decided to place the blind in isolation at a defunct mental asylum - an action that happens both quickly and without any dialogue between officials and the infected. Parallels are drawn between the moral treatment of those deemed to be "insane" - as already depicted in classic cinema such as One Flew over the Cuckoo's Nest (Milos Forman, 1975)—where the asylum becomes a context for the oppressive and repressive imposition of rationalized order (Foucault, 1961). In Blindness, the infected are forcibly removed into isolation and then placed under camera supervision and physically watched by guards with weapons at postings high above the facility. We also see the eradication of trust in medical authority in the film, as one of the main protagonists, the male ophthalmologist, begins life in the isolation facility as his ward's "official representative", but over time as conditions worsen, the other infected people lose confidence in him, and he becomes usurped by others-including his own wife. This later is manifested further in a case of strong interpersonal distrust as the ophthalmologist then goes on to have sex with the woman presented as a sex worker - a betrayal of strong significance given that his wife who is not infected with blindness had spent much of the film voluntarily guiding and supporting him and others in the facility.

Inside the facility itself, different forms of social distrust emerge across the course of the film - particularly as more people are placed into isolation and the wards become fuller - and relationships within the initially well-regulated environment soon start to unravel in a quasi-Hobbesian state of nature (Chesney, 2021). It is not clear whether the choice of a Japanese man as the first person to be infected with the blindness is a subconscious form of Orientalized othering committed by the director, or a conscious and deliberate critique of this phenomenon that is frequently seen during epidemics. This is tied up in broader "yellow peril" frameworks which have a long history (Lynteris, 2018a), and was demonstrated, for example, in the victimization of Chinese people in Chinatowns in the United States during Third Plague Pandemic outbreaks (Risse, 2012; Shah, 2001), but also manifested itself in xenophobic abuse reported towards East Asians in many parts of Western Europe during the early phases of the COVID-19 outbreak. Whatever the reality of the director's intentions, it is a useful entry into the issue of social distrust as the film's starting scene. As the Japanese man is unable to drive through his sudden blindness, people are impatient and honk their horns. As he shouts "help", nobody comes to his aid. In the end, he is assisted by someone, but even this turns out to be an abuse of trust as this man has dishonest intentions - attempting to steal items from the Japanese man's house, and then taking off with his car.

Social distrust is an issue further developed in the moralizing take on the specific choice of victims of the disease. Not everyone in society is afflicted, and 
it appears as though this sudden contagious blindness is being presented as a punishment or corrective for perceived immoral behavior. This kind of moral narrative has its roots in how societies in the distant past have explained outbreaks of certain diseases - for example, the notion that the Black Death and recurring plagues thereafter were a providential punishment from God for selfishness, greed, ostentation, or a lack of piety, as elaborated upon already in Chapter 2. In the film itself, explicit reference is made to this issue. Statues in the church, including a crucified Jesus, have all been blindfolded, and the eyes of saints in the stained-glass windows have been taped over. The characters in the film all have differing views on its symbolism. Some suggest that it refers to a show of solidarity with those who are blind, while others point to the likelihood of a shattered faith - hinting even to a distrust in God herself. Those who become blind are presented in moralizing terms - the thief ends up blind himself, and is punished further when attempting to grope a woman in the isolation facility, receiving a wound that later proves fatal. The sex worker (Alice Braga) is also presented in moralizing terms - although perhaps more relating to the attitudes of others towards her. Once blind, she is abandoned by her client and left to fend for herself, until she is humiliated and thrown out of the hotel naked. These examples contrast with the situation of the wife of the ophthalmologist, whose apparent caring and selfless nature is reflected in the fact that she is one of the only characters not to go blind in the film. She continues to demonstrate those characteristics throughout the film - first tending to the immediate needs of her husband, even forgiving him of infidelity, second, working to ensure the safety and protection of others in her ward, and third, once escaped from the facility, guiding her followers to safety.

A final aspect of social distrust depicted in the film can be seen within the divisions of the isolation facility itself. In the end, wards do not work together but compete with each another, as seen in the dramatic conflict played out between ward one and ward three. In a desperate power struggle, certain members of ward three end up using the threat of violence - based on their access to weaponry - to hoard resources and food away from the other wards. This is then turned into an ultimatum whereby the men of ward three require coerced sex from the women of ward one, in exchange for rations. This demand even eventually leads to the grisly death of one of the women during a rape scene. The whole situation descends into a case of cruelty, abuse, and extreme violence - and a final fierce struggle between the two wards becomes the final context for members of ward one to escape from the facility entirely.

However, although Blindness focuses on many aspects of distrust-which in the end are manifested through various forms of alienation and lack of solidarity leading to hatred and violence - the film also emphasizes different ways in which epidemics can serve to establish new lines of trust between certain groups and individuals, leading the way to heightened forms of social cohesion. Indeed, although on the one hand, the disease itself is partially framed in a moralizing narrative as a punishment for self-interest and greed, on the other hand, the pre-existing inequalities and injustices serve as a background context which is reshaped during the "abnormal" conditions of the epidemic. For example, in contrast to the 
classic narrative of Camus, where the disease deprives everyone of the powers of love and friendship, Blindness offers a narrative of interdependency attempting to overcome precarity.

The film achieves that very clearly by zooming in on the particular changing status of certain individual characters: bringing out the worst, but also the best in people. The woman with the dark glasses is a part-time sex worker, struck blind while with a client. Although entering the facility cold and condescending, the woman takes on new roles and responsibilities which reflect a more complex and nuanced identity, beyond the mere categorization as a sex worker. Eventually, this woman becomes a protective caregiver for a young blind boy, whose mother was not found in the isolation facility, and she strikes up a loving bond with an older man with a black eye patch (Danny Glover). This man urges us to reflect upon our prejudices towards seeing this woman as one thing: reassuring her "I know the part inside of you with no name". As the last man to join the facility, he also sees his fortunes change in the context of the ongoing epidemic. Upon escaping isolation and once in the safe confines of the ophthalmologist's house, the man reflects upon his status both pre- and post-blindness, noting that prior to the disease, his status was defined by his otherness - perhaps down the lines of racial discrimination, perhaps through poverty, or perhaps simply through his eye patch. For this man then, the disease had an egalitarian effect-for the first time simply accepted as a person struggling like any other. For Meirelles, or rather Saramago as the author of the original novel, the "pre-blind" society was actually the society without vision, and it takes epidemic blindness to begin to see aspects previously obscured from society's consciousness. The same story can also be found within the facility itself in the fortunes of the man who has been blind since birth-although this time not presented in favorable terms. As an experienced blind person, he is the only one in the ward who can read and write braille, can use a walking stick, and has a better command of his other senses. In the end, this man uses this reversal of fortune for his own individual gain, however, becoming second in command to the man with the gun in ward three, in the process making money and exploiting the women of ward one.

While on the one hand the contrast between ward one and three points to inevitable conflict, elements of cohesion also come to the surface. As ward three becomes an inhospitable environment, ward one takes on the features of a close-knit family. Interestingly, we never learn any of the names of anyone in the film - and that serves to emphasize the breakdown in social hierarchy seen in the isolation facility. Much of the solidarity seen in the film is also presented down gender lines - with an inequitable proportion of burdens and responsibilities falling on women. As already noted, one of the most traumatic events taking place in isolation is the rape of a number of women from ward one by men from ward three. The film's presentation of this kind of situation is perhaps understandable given that a wide range of scholarly and charitable literature now emphasizes that terrible hazards and shocks - epidemics, famines, floods, earthquakes, and the like - tend to afflict women and girls to a much more severe degree than men (Neumayer and Plümper, 2007; Wenham et al., 2020a; 2020c; Smith, 2019; for a 
historical view: Curtis, 2021), providing various kinds of traumas, burdens, and hardships that are discussed more at length in Chapter 5. In the beginning, the blind women of ward one are subjected to the harrowing experiences of sexual abuse by men from ward three-female bodies reduced to "commodities" that could be traded for subsistence items such as bread and milk for the rest of the ward. In the end, however, under the leadership of the doctor's wife, the women work together with collective solidarity to instigate a successful overthrowal of the violent and despotic group of male bandits, and lead the rest of the ward to escape the confines of the institution.

\section{The Painted Veil (John Curran, 2006)}

The Painted Veil is a 2006 American drama film that is based on a novel from 1925 written by English playwright, W. Somerset Maugham, and is the third film adaptation following the initial 1934 version starring Greta Garbo and Herbert Marshall and a 1957 version (called The Seventh Sin) featuring Bill Travers and Eleanor Parker. The film takes place in the 1920s and follows the attempts of a British bacteriologist to help bring a cholera outbreak under control in a rural and remote area of China. The story begins in London, where the bacteriologist Walter Fane (Edward Norton) proposes marriage to a vain socialite Kitty Garstin (Naomi Watts). Eventually they end up in Shanghai, where Walter is working in a government laboratory studying infectious diseases.

From the very beginning, signs of strain can be seen in their relationship. Walter is entirely consumed by his work and Kitty is more interested in the social life of the British high society in Shanghai. Ultimately, this leads to an affair between Kitty and Charles Townsend (Liev Schreiber), a married British vice consul, and as a punishment, Walter forces his wife to accompany him on a dangerous and uncomfortable journey to a remote village in the interior where a cholera outbreak had taken hold. Living conditions are squalid, and Kitty finds herself isolatedunable to talk to Walter, with only the company of a Chinese housekeeper ( $\mathrm{mmah}$ ) and soldier assigned to guard her, and a British deputy commissioner, Waddington (Toby Jones), as a next-door neighbor. To escape her boredom and isolation, Kitty volunteers at the local orphanage run by a group of Catholic missionaries (led by Diana Rigg), and it is in this context that she begins to see her husband in a new light_recognizing his selfless and caring side. As the epidemic becomes more severe, the relationship between the two solidifies, with Walter also reconsidering his perception of his wife.

Much of the story addresses the issue of the cholera outbreak. Walter tries to implement new public health controls founded on the germ theory explanation of disease spread - regulations which are initially rejected and resisted by the local population (who still lean towards miasmatic and spiritual explanations) - but eventually are accepted. Just as the situation appears under control, however, displaced refugees from other cholera-stricken communities come into the village, creating new sources of contagion. Walter has no option but to set up a quarantine camp outside the settlement, but in the process becomes infected and dies a grisly 
and painful death. Kitty, by this time pregnant, leaves China. The film ends some five years later in London as Kitty, accompanied by her young son Walter, bumps into Charles by chance and rejects his advances.

Interpersonal distrust has a substantial role in The Painted Veil-just as in Blindness manifesting itself in an extra-marital affair - and in turn only exacerbating distrust further. Partially this is explained by the selfish behavior of Kitty and her superficial desires for accepting Walter's proposal (she just wanted to get as far away as possible from the oppressive control of her mother), but also as a result of Walter's personal flaws - his coldness, poor communication, and lack of empathy - and the loneliness derived from an unfamiliar, and perhaps even directly hostile, new cultural environment. However, it could also be said that most of the interpersonal distrust in the film serves as a backdrop to the incipient stages of the epidemic — but paradoxically, as the cholera worsens, the relationship between the two protagonists strengthens. Another form of interpersonal distrust is seen in the mysterious and seemingly ambiguous position of British neighbor, Waddington. The viewer at first is unsure to what extent the relationship between Waddington and a young Chinese woman, Wan Xi (Lü Yan), is exploitative or not-Wan $\mathrm{Xi}$ is presented in a stereotypically Orientalized image as exotic and mysterious, but at the same time submissively returning to Waddington even after he has sent her away a number of times (for the subservient "China Doll" image, see: Han, 2016: 82). This ambiguity can be seen in a later interaction between Kitty and Waddington: Kitty is about to hand over a personal letter to Waddington - in the hope that he can help her-but decides not to do so when she starts to doubt whether he can be trusted with the information.

Social and institutional distrust are difficult to untangle from one another in The Painted Veil-largely because the lines between who is the elite or authority and who is not are rather blurred. Walter brings with him "modern" Western knowledge of biomedicine, but also has to operate within an arena where he is subject to the threat of violence - ceding authority to a Chinese army general in the broader context of nationalist uprisings and anti-Western sentiment against quasi-colonial occupation. The context of nationalist sentiment-already stirred up in the student protests over the perceived injustices of the Treaty of Versailles in 1919 (the May Fourth Movement) as a "humiliation" for China-were further agitated by the anti-imperialist May Thirtieth Movement in response to the British Shanghai Municipal Police opening fire on a group of Chinese protesters (for background: Bickers, 2018). In that kind of political background, we can understand the villagers' deep-rooted distrust in Walter — not only as an outsider, but as someone to them representing oppressive and extractive British colonial presence within China. Local agitation is perhaps only exacerbated by other forms of outsider intrusion such as the central presence of French Catholic missionaries within the village.

However, while anti-imperialistic sentiment may provide the background for distrust, much is also related to Walter's own personal characteristics - as a bacteriologist used to working in a laboratory rather than a field doctor-he lacks some of the "softer" skills required in dealing with sick people, and forging useful 
relationships and networks. Accordingly, important figures such as the army general, Colonel Yu (Anthony Wong), have an initially frosty relationship with Walter. In one telling scene, Colonel Yu tells Walter that he thinks "China belongs to Chinese people, but the rest of the world seems to disagree", whereas Walter is unreceptive to the broader historical and political context-simply replying "That's got nothing to do with me. I didn't come here with a gun, you know. I came here with a microscope". Walter's retort is perhaps ironic in the sense that repressive colonial infrastructure and apparatus - especially from the nineteenth century onwards - was often solidified and justified through the application of public health policy (Harrison, 2017: 132; Arnold, 1993). However, it should also be noted that the "outsider" concept within the film is multilayered, since a level of distrust also exists between Colonel Yu himself and some of the ordinary inhabitants of the rural village.

It is clear that the initial solutions put forward by Walter-informed by a completely different framework of disease management-were also not easily accepted by the local village population. Indeed, the first time we see the rising discontent of villagers is when Walter suggests moving bodies from burial site close to the river to avoid contaminating the water-something which stands in direct conflict with the customary practices of placing the dead closer to the river to move on more swiftly to the afterlife. This anger was further exacerbated by Walter's additional suggestion to remove all corpses and bury them as soon as possible - this time in conflict with the customary expectation of allowing a number of days to elapse with the bodies laid out in the house before burial. In one dramatic scene, after the camera pans away from the close-up shot of a poster announcing a government ordinance, we see the anguish etched on the faces of the frantic villagers, as the army marches into the households and carries off the corpses. As already noted in Chapter 2, on the one hand we may be slightly suspicious of this narrative from a Western director, perhaps subscribing to a kind of Orientalist imagination about the "backwards" or "primitive" practices that might have occurred in a rural village in early twentieth-century China, but at the same time, medical history has verified some of this narrative. Indeed, in the 1920s and 1930s in rural China, outsider and elite medical reformers' lack of attention paid to internal village politics and power dynamics limited the overall effectiveness of public health prevention and education, as local populations held on to the same daily routines (Merkel-Hess, 2016; Barnes, 2018), and as a result created widespread resistance to developments such as free inoculation campaigns (Brazelton, 2019: 25).

Although The Painted Veil deals with many cases of distrust on all three levels - interpersonal, social, and institutional —we could also see that the film provides a clear narrative in which trust becomes fully reestablished. This occurs across two dimensions: first, in the personal relationship between Walter and Kitty themselves, and second, in Walter's interactions with the local community that facilitates his public health interventions. In the case of Walter and Kitty, as already noted, we find that the worsening of the cholera crisis within the village corresponds temporarily with the strengthening of their bonds in marriage. As 
Walter loses himself ever further in his work, Kitty becomes isolated to an even greater degree - forcing her to carve out a new role for herself within the orphanage run by the French Catholic nuns. It is only in this context that the couple see a different, previously obscured, side to each other-and become reconnected via their emotional attachment to issues taking place within the village itself. The episodic nature of an epidemic outbreak has been used before in cinema to frame a reconciliation of two distant or estranged partners - see, for example, the Soviet film Неповторимая весна [Nepovtorimaya vesna/A Unique Spring] (Aleksandr Stolper, 1957), where a woman joins her husband on an archaeological excavation in Central Asia, only for plague to break out and be the context behind her parents coming together. Aside from her husband, the cholera crisis also serves as a context for Kitty to begin to establish her own trust of the local community itself - perhaps even to a greater degree than Walter, whose relationship with the locals continues to be ambiguous at best. At the beginning, Kitty is lonely and uncomfortable, infuriated by her interactions with the amah (Gesang Meiduo)caught staring at her - and the overbearing protection of bodyguard, Sung Ching (Li Feng), who is frequently told to stop following her around. Yet as the film progresses, Kitty is found readily accepting the dutiful services of Sung Ching, and in one scene, continues to eat the uncooked salad leaves of the housekeeper, despite the protestations of Walter on hygiene grounds.

Although Walter encounters resistance to his ideas through widespread distrust in the local community, he is eventually able to win the confidence and cooperation of the people by better establishing a more reciprocal relationship within local power hierarchies. At first, the army general attached to the village shows hostility to the presence of an outside authority dictating terms, yet upon establishing a dialogue, the relationship between the two improves - and in one case Colonel Yu saves Walter and Kitty from the advances of a malicious group of locals, stirred up with nationalistic sentiment, by firing a gun into the air. Colonel $\mathrm{Yu}$ and Walter begin to establish trust on the basis of a shared respect for their respective professionalism - but also common language and open-mindednessand at the end of the film, the general is found weeping upon witnessing Walter's death in the cholera camp.

The establishment of trust between Walter and the community, however, is only confirmed once Walter gets the approval from a local feudal warlord for his idea to establish an aqueduct of fresh running water across large distances. ${ }^{2}$ The film is unclear about whether the eventual cooperation of the villagers stemmed from being convinced by the approval of the local lord or from overall fear of violence and submission to power (on this uneasy and reluctant fealty of rural communities to warlords in this period: Lary, 1985)_but what is apparent is that his support remained vital. Intriguingly, this warlord himself remained entirely unconvinced until the army general stepped in as a form of conversational buffer - using both his local authority and his cultural position to know exactly what to say and how to frame things. After Walter insults the warlord in English-“Tell him that's the most ridiculous suit that I've ever seen"-Colonel Yu turns to the warlord, and remarks, "This Doctor respects you greatly, and you are right. It is quite a mess, 
this epidemic. But my superior said if your men cannot control it, then our army will be happy to come out here and help you". The combination of praise, respect, and a not so thinly veiled threat from the army general help Walter negotiate the difficulties of local political networks and power hierarchies - providing him the space to put his ideas into action.

\section{Contagion (Steven Soderbergh, 2011)}

Soderbergh's Contagion was produced in 2011 — appearing in the aftermath of a number of serious epidemic outbreaks including SARS and various forms of influenza $(\mathrm{H} 1 \mathrm{~N} 1 / \mathrm{H} 5 \mathrm{~N} 1)$. The film centers on the unfolding of a global pandemic, which we later find out is a mutated virus derived of genetic material from bats and pigs (given the name Meningoencephalitis Virus One or MEV-1), and by the time a vaccine has been developed, the seriousness of this situation is seen in a projected infection rate of $8.3 \%$ and a mortality rate of around 25 to $30 \%$. The film begins on the second day of the outbreak in Hong Kong and then proceeds to show the spread of the infection across many parts of the world across hundreds of days. At the end of the film, we are taken back to the first day, where we are shown the origins of the disease: the disruption of the natural habitat of a bat by human construction pushes the bat to fly over a pigpen, in the process dropping a piece of banana. A pig consumes the banana, which is then sold by farmers to a chef in a Macau casino. The failure to wash his hands while handling the pig carcass passes the virus to an American woman, Beth (Gwyneth Paltrow), traveling on business, after he shakes her hand.

Across the course of the film, the viewer is taken from various locationsChicago and Minneapolis in the United States, where Beth traveled back to from Hong Kong, as well as scenes of the infection unfolding in London, Hong Kong, Macau, and other parts of China such as Guangdong. As a global outbreak we are taken through the responses of various kinds of institutions and actorsgovernments, disease management authorities (the CDC), global health authorities (the WHO), media outlets, pharmaceutical companies, hospitals, and many more-but the macro-level analysis of a global pandemic is also broken down into the micro level through the numerous overlapping stories of the individual protagonists, ranging from elites, authorities, and experts to ordinary citizens. Although we see many of these characters in their official role as doctors, epidemiologists, scientists, and other kinds of public health worker, we also come to see that these same characters have personal lives beyond their jobs-emotional connections with others that also dictate the nature of their response during the epidemic, and perhaps lead them to deviate from established administrative or regulatory protocols required by formal institutions.

Overall, the virus presented in the film is not just the cause of a global pandemic, but is also a metaphor for fear and distrust - often heightened through media messages - and further exacerbated down socio-economic, cultural, and racial lines. Just as in Blindness and The Painted Veil, an extra-marital affair is instrumentalized in the film as a way of demonstrating a major case of interpersonal 
distrust. Mitch Emhoff (Matt Damon) finds out that his deceased wife, Beth, was unfaithful with an ex-partner named John Neal, which accordingly leads to the spread of the disease in Chicago. The use of this kind of "female spreader" image — common to films dealing with epidemic disease outbreaks — is elaborated upon more fully in Chapter 5.

Quite frequently, strong levels of distrust down various lines turn into levels of mistrust: that is people believing in spurious or dubious forms of information. This can be seen clearly in the institutional distrust in authorities - both medical and governmental — which leads to mistrust in online sources of information peddling pseudoscience. Throughout the film, expert opinion gets sidelined in favor of blogs, which conspiracy theorists such as Alan Krumwiede (Jude Law) exploit to spread unsubstantiated allegations about the disease-for example, that it was deliberately engineered. As we go further into the worst phases of the epidemic, as well as discrediting other authorities such as the CDC and the WHO, Krumwiede pretends to be sick so he can "cure" himself with a homeopathic remedy, forsythia, and presents this to millions of followers online-a financially lucrative move given that he stands to make money from promoting the same remedy. The actions of authorities in charge of distributing resources are also consistently brought into question - with the themes of corruption and inegalitarian intentions within pharmaceutical companies now a staple of films depicting epidemics: see, for example, the mutation of Zika within Malaysia represented in Jai mat tse moon/The Leakers (Herman Yau, 2018). The kidnap of the WHO epidemiologist from Geneva by a Chinese official, Sun Feng, is done with the realization that the distribution of eventual vaccines was not likely to be an equitable process - of obvious resonance with the contemporary COVID-19 situation seen just ten years later. In another case, ordinary people are waiting in anticipation of receiving drugs and food but the sudden rationing of these resources among a distrusting population inevitably leads to uproar and violent confrontation. This corresponds strongly with social science theories on the breakdown of "entitlements" (the original concept derived from famine studies through Sen, 1981), where protective or paternalistic authorities trusted to keep people safe and provide welfare fail to meet common expectations or a "social contract" (Bohstedt, 2016; Tilly, 1983).

Social distrust is also present in the film in various forms - understandable given the contagiousness and lethality of the virus. Stereotypical social breakdown scenes are found in certain places: the violent looting of banks, stores, and people's unprotected homes, dysfunction in police responses, and the buildup of uncollected trash around various cities. Upon realization of these dangers, one of the film's major protagonists, Mitch Emhoff, acquires a shotgun for himself as a form of protection. Contagion also zooms in on forms of exoticism and othering often seen during epidemic responses — although like with Blindness and The Painted Veil - it is difficult to ascertain whether this is a conscious critique or a subconscious employment of the same flawed approaches. Whatever the reality, it is certainly no coincidence that the roots of the disease are seen in Macau, Hong Kong, and parts of mainland China. 
Although at the heart of Contagion is a clear story of distrust along all three lines - institutional, social, and interpersonal-the film also shows elements of solidarity and compassion between some of the characters. Frequently this is demonstrated in the courageous and skilled work of many of the public health professionals in dealing directly with the disease - often going beyond the "call of duty" to help others at great risk to their own lives (Lynteris, 2016a), as discussed further in Chapter 4 on medical responsibility. We see Dr. Ally Hextall (Jennifer Ehle) working consistently in a secured lab to try and isolate the virus and develop a serum. In the end, she risks her own life by testing the vaccine on herself. The same could be said of the WHO epidemiologist sent to Hong Kong to find the origins of the MEV-1 pathogen. Although effectively kidnapped by Sun Feng, and used as leverage to obtain vaccines for his family's village, Dr. Orantes not only is found educating the local children in one scene (also instructive as the bestowal of "knowledge" from West to East), but upon realizing that the village were given placebos instead of real vaccines, voluntarily goes back there to help. Similar types of actions were seen in the CDC workers. Dr. Erin Mears (Kate Winslet), an Epidemic Intelligence Officer, begins investigating the situation in Minneapolis but in the process is infected herself. In her final act, she is seen passing a coat to another sick person for warmth, just before she dies. She is then zipped up and thrown into a mass burial site - a cold and brutal scene that neither glorifies Dr. Mears as a hero nor reflects too long with sentiment or tragedy. The female burden and selfsacrifice again appear as themes, analyzed in greater detail in Chapter 5: mirroring the women-led escape from the institution in Blindness, and Kitty's transformation into principal caregiver in The Painted Veil. Indeed, Dr. Mears's self-sacrifice is brought into further focus by being juxtaposed against a decision to divert a flight, originally scheduled to pick her up, to instead collect an "important" politician.

The CDC director (Laurence Fishburne) is also seen to show compassion in the face of difficult circumstances - at the end of the film eschewing his right to an early vaccine and giving it to a small boy from a poorer family. Furthermore, Dr. Cheever takes direct responsibility for perceived mistakes; for example, accepting with humility the investigation into his behavior, after he had told his fiancée to evacuate before announcing it publicly. This inequity in resource or information distribution - providing for one's "own people" first-is something not specific to Contagion, but critiqued in the likes of Flu and Outbreak (Doherty and Giordano, 2020). It must also be noted, however, that these compassionate responses often come out of breaking established rules and protocols from their superiors or institutions. Dr. Cheever himself explicitly states later in Contagion that he would do the same again - that is, break the official rules - if given the choice. Dr. Hextall continues to work on the vaccine in the laboratory despite instructions for her to stop, accelerating the clinical trials by injecting herself with an experimental serum, and deliberately infects herself to put the developed antibodies to the test (McGuire, 2021: 5). Accordingly, the film shows an uneasy coexistence between decisions made out of compassion for others, but usually only enabled by disregard for official practices - a disregard to some extent created by prevailing levels of institutional distrust. 
Another aspect of the film that concerns the reestablishment of trust is the continual attempts to maintain close personal networks with others and ordinary practices - something that the epidemic problematizes. Indeed, this is an issue recently brought into focus during the earliest phases of the COVID-19 outbreak in China, where a WeChat diary from a quarantined Wuhan resident noted that "it is not easy to build trust and bonds under a lockdown" but at the same time "social participation is an important need" (Anon., 2020a). On a number of occasions, we see the two teenagers, Jory Emhoff (Anna Jacoby-Heron) and Andrew (Brian O'Donnell), attempting to meet each other and socialize - despite the best efforts of Jory's father to separate them. The need for the continuance of ordinary life is seen at the end of the film, where the father puts on a special "Prom Night" dance for the pair at their own house - in light of the isolation conditions - and informing his daughter, "It's gonna start getting normal again" (also recently critiqued as an overly optimistic narrative arc of eluding the virus and the resumption of a previous "ordinary" life: McGuire, 2021). Earlier in the film, the same father was left distraught when he was told by the undertaker that he could not bury his wife and son at his cemetery - despite the fact that he already had a family plot.

\section{Conclusion}

The three films chosen for analysis in Chapter 3-Blindness, The Painted Veil, and Contagion - each reflect upon the capacity of different societies to exhibit levels of distrust during and in anticipation of epidemic disease outbreaks. These elements of distrust can be classified as institutional, where communities lose confidence in the actions and decisions of elites and authorities; social, where communities begin to distrust each other, or more frequently, "outsiders" to these specifically demarcated communities; and interpersonal, where individual relationships within families, households, friends, and neighbors begin to break down. Recurring features within these three films are the use of extra-marital affairs between the main protagonists to demonstrate suspicion and distrust at the very micro level - an approach that the medium of films and television can perform very well given their focus on the thoughts, feelings, and decisions of individual characters. These affairs are widely seen in epidemic-related films across various genres - from the action and suspense of The Cassandra Crossing (George Pan Cosmatos, 1976), the horror of Vampire Circus, to the historical drama of En kongelig affere (Nikolaj Arcel, 2010).

Another feature recurring within the films is a form of othering-even if it is subconsciously integrated rather than a deliberate cinematic critique-by exoticizing the threat of disease transmission and spread. In The Painted Veil, this is turned around in the opposite direction, as the "exotic" - the timeless rural Chinese village as the nexus of infection-is "saved" by a selfless Western bacteriologist risking his own life, despite their apparent incapacity or unwillingness to appreciate the health risks presented to them. These issues, firmly placed in mainstream cinema, are of obvious relevance to us when we consider (a) the effectiveness of popular culture in presenting public health issues to a broader lay 
audience, explained in Chapter 1 and (b) the recent portrayal of the origins and spread of COVID-19 as effectively a "moral" issue relating to economic practices and social life in China.

These kinds of films also provide unexpected sources of nuance to how trust and distrust might be forged during epidemic outbreaks. First, in each of the films, it is emphasized how suspicion and prejudice are not features which suddenly emerge out of entirely new conditions created by fear of the pathogen. In fact, suspicion and prejudice are often ingrained features of societies before the appearance of epidemics, and informed by structural inequalities based on race, gender, and socio-economic status. Epidemics may simply bring these characteristics to the surface-holding them up to the light, where they were previously obscured. Second, and on a related note, the three films of analysis also suggest that while epidemics will often exacerbate and pull apart pre-existing inequalities, this might not be a universal rule (as suggested in the historical literature: Cohn, 2018). Frequently, we find situations where both distrust and cohesion can coexist simultaneously in the same way that tolerance and prejudice can coexist - with the lines between these concepts much more blurred than what appears on the surface. Indeed, this point can be reinforced when approaching these films through the three levels of breakdown in trust, where institutional distrust - often by communities towards elites or authorities-is sometimes mediated or negotiated, perhaps even compensated for, by reinforced solidarity of trust at the social level, within or between communities. This is something not exclusive to these three films of explicit focus in Chapter 3. Thus, for example, in the previously mentioned Yesterday, Today, Tomorrow, citizens' distrust in colonial authorities during the rat-induced plague outbreak in Hong Kong also occurred simultaneously to messages emphasizing a universal form of fraternity based on bonds of human sympathy - the restoration and reconstruction of "community".

However, it is important to emphasize, especially with regard to the next chapters, that this communal solidarity also leads to a greater demarcation of who is not included, sharpening the lines of exclusion. In Chapters 5 and 6, we reflect on how films often show how certain social groups are left behind-in these cases certain women, and certain (but not all) groups of the poor, heightening structural vulnerabilities. Before that, however, in Chapter 4, we zoom out once again to the larger corpus of films already addressed in Chapter 2 , to show some of the complexities of and contradictions in the breakdown in trust seen during epidemics - especially regarding interaction between elites, authorities, experts, and "ordinary people"by focusing on the visual representation of public health workers within cinema.

\section{Notes}

1 “The Painted Veil (2016)", IMDb, accessed January 25, 2020, www.imdb.com/title/ tt0446755/?ref_=nv_sr_srsg_1; "Blindness (2008)", IMDb, accessed January 25, 2020, www.imdb.com/title/tt0861689/?ref_=nv_sr_srsg_0; "Contagion (2011)", IMDb, accessed January 25,2020 , www.imdb.com/title/tt1598778/. Contagion grossed more than eight million dollars on its opening night (McGuire, 2021: 6). 
2 Indeed, the film is set within the early Republican period of China known as the "Warlord Era", which refers to the power vacuum produced in the context of the collapse of the Qing Dynasty.

\section{References}

Anon. "Ebola: Attackers Kill DR Congo Journalist Shining Light on Virus." BBC News, November 3, 2019a, www.bbc.com/news/world-africa-50283286.

Anon. "Building Trust Is Essential to Combat the Ebola Outbreak." Nature 567 (2019b): 433.

Anon. "Coronavirus Wuhan Diary: Living Alone in a City Gone Quiet." BBC News, January 30, 2020a, www.bbc.com/news/world-asia-china-51276656.

Arnold, David. Colonizing the Body: State Medicine and Epidemic Disease in NineteenthCentury India. Berkeley, CA: University of California Press, 1993.

Barnes, Nicole Elizabeth. Intimate Communities: Wartime Healthcare and the Birth of Modern China, 1937-1945. Berkeley, CA: University of California Press, 2018.

Beck, Ulrich. Risk Society: Towards a New Modernity. New Delhi: Sage, 1992.

Bickers, Robert. Out of China: How the Chinese Ended the Era of Western Domination. St. Ives: Penguin, 2018 [2017].

Blair, Robert A., Benjamin S. Morse and Lily L. Tsai. "Public Health and Public Trust: Survey Evidence from the Ebola Virus Disease Epidemic in Liberia." Social Science and Medicine 172 (2017): 89-97.

Blakey, Shannon M., Lilian Reuman, Ryan J. Jacoby and Jonathan S. Abramowitz. "Tracing 'Fearbola': Psychological Predictors of Anxious Responding to the Threat of Ebola." Cognitive Therapy and Research 39, 6 (2015): 816-825.

Bohstedt, John. "Food Riots and the Politics of Provisions from Early Modern Europe and China to the Food Crisis of 2008." Journal of Peasant Studies 43, 5 (2016): 1035-1067.

Brazelton, Mary Augusta. Mass Vaccination: Citizens' Bodies and State Power in Modern China. Ithaca, NY: Cornell University Press, 2019.

Brownlie, Julie. "Conceptualizing Trust and Health.” In: Julie Brownlie, Alexandra Greene and Alexandra Howson (eds.), Researching Trust and Health, pp. 17-32. New York: Routledge, 2008.

Butler, Judith. Notes Toward a Performative Theory of Assembly. Cambridge, MA: Harvard University Press, 2015.

Calain, Philippe and Marc Poncin. "Reaching Out to Ebola Victims: Coercion, Persuasion or an Appeal for Self-Sacrifice?" Social Science and Medicine 147 (2015): 126-133.

Chesney, Duncan McColl. "Re-Reading Saramago on Community: Blindness." Critique: Studies in Contemporary Fiction 62, 2 (2021): 211-223.

Cohn, Samuel Kline. Epidemics: Hate and Compassion from the Plague of Athens to AIDS. Oxford: Oxford University Press, 2018.

Cohn, Samuel Kline and Ruth Kutalek. "Historical Parallels, Ebola Virus Disease and Cholera: Understanding Community Distrust and Social Violence with Epidemics." PLoS: Current Outbreaks 1 (2016), http://currents.plos.org/outbreaks/index.html\%3Fp=64080. html.

Conquergood, Dwight. "Performance Studies: Interventions and Radical Research." The Drama Review 46, 2 (2002): 145-156.

Curtis, Daniel R. "Preserving the Ordinary: Social Resistance during Second Pandemic Plagues in the Low Countries." In: Christopher Gerrard, Paolo Forlin and Peter Brown 
(eds.), Waiting for the Ends of the World: Perceptions of Disaster and Risk in Medieval Europe, vol. 43, pp. 280-297. London: Routledge, 2020.

Curtis, Daniel R. "The Female Experience of Epidemics in the Early Modern Low Countries." Dutch Crossing: Journal of Low Countries Studies 45, 1 (2021): 3-20.

Doherty, Jane and James Giordano. "What We May Learn - and Need-From Pandemic Fiction." Philosophy, Ethics, and Humanities in Medicine 15, 4 (2020), https://peh-med. biomedcentral.com/articles/10.1186/s13010-020-00089-0.

Donohue, Micah K. “Adaptation, Abjection, and Homecoming in Saramago's Ensaio Sobre a Cegueira and Meirelles's Blindness." Hispanófila 179 (2017): 77-95.

Foucault, Michel. Folie et Déraison: Histoire de la folie à l'âge Classique. Paris: Librairie Plon, 1961.

Gesser-Edelsburg, A. "Risk Communication and Infectious Diseases in an Age of Digital Media." International Journal of Infectious Diseases 79, 1 (2019): 130-131.

Gilman, Sander L. "Moral Panic and Pandemics.” The Lancet 375, 9729 (2010): 1866-1867.

Han, Qijun. The Cinematic Representation of the Chinese American Family. Cambridge: Cambridge Scholars Publishing, 2016.

Harrison, Mark. "Pandemics." In: Mark Jackson (ed.), The Routledge History of Disease, pp. 129-146. New York: Routledge, 2017.

Hood, Johanna. HIV/AIDS, Health and the Media in China: Imagined Immunity through Racialized Disease. Abingdon: Routledge, 2011.

Kendal, Evie. "Public Health Crises in Popular Media: How Viral Outbreak Films Affect the Public's Health Literacy." BMJ: Medical Humanities 47, 1 (2021): 11-19.

Khan, Shamshad. "Manufacturing Consent?: Media Messages in the Mobilization against HIV/AIDS in India and Lessons for Health Communication." Health Communication 29, 3 (2014): 288-298.

Kutalek, Ruth, Shiyong Wang, Mosoka Fallah, Chea Sanford Wesseh and Jeffrey Gilbert. "Ebola Interventions: Listen to Communities." The Lancet Global Health 3, 3 (2015): e131.

Lary, Diana. Warlord Soldiers: Chinese Common Soldiers 1911-1937. Cambridge: Cambridge University Press, 1985.

Lynteris, Christos. "The Epidemiologist as Culture Hero: Visualizing Humanity in the Age of the Next Pandemic.” Visual Anthropology 29, 1 (2016a): 36-53.

Lynteris, Christos. "Yellow Peril Epidemics: The Political Ontology of Degeneration and Emergence." In: Frank Billé and Soren Urbansky (eds.), Yellow Perils: China Narratives in the Contemporary World, pp. 35-59. Honolulu, HI: Hawaii University Press, 2018a.

Maxmen, Amy. "Ebola Responders Killed as Violence Flares." Nature, November 26, 2019, www.nature.com/articles/d41586-019-03667-1.

McGuire, Kelly. "COVID-19, Contagion, and Vaccine Optimism." Journal of Medical Humanities 42, 1 (2021): 51-62.

McKinlay, Alan. "Foucault, Plague, Defoe." Culture and Organization 15, 2 (2009): 167-184.

Merkel-Hess, Kate. "The Public Health of Village Private Life: Reform and Resistance in Early Twentieth Century Rural China.” Journal of Social History 49, 4 (2016): 881-903.

Millard, William B. "Ebola Preparedness: On Avoiding Making a Scary Virus Scarier." Annals of Emergency Medicine 65, 2 (2015): 15-20.

Moran, Mary H. "Missing Bodies and Secret Funerals: The Production of Safe and Dignified Burials in the Liberian Ebola Crisis." Anthropological Quarterly 90, 2 (2017): 399-421.

Muzzatti, Stephen L. "Bits of Falling Sky and Global Pandemics: Moral Panics and Severe Acute Respiratory Syndrome (SARS).” Illness, Crisis and Loss 13, 2 (2005): 117-128. 
Neumayer, Eric and Thomas Plümper. "The Gendered Nature of Natural Disasters: The Impact of Catastrophic Events on the Gender Gap in Life Expectancy, 1981-2002." Annals of the Association of American Geographers 97, 3 (2007): 551-566.

Risse, Gunther B. Plague, Fear, and Politics in San Francisco's Chinatown. Baltimore, MD: John Hopkins University Press, 2012.

Rueda, Carolina. "Aesthetics of Dystopia: Blindness from Novel to Film." World Literature Today 89, 3-4 (2015): 12-15.

Ryan, Molly J., Tamara Giles-Vernick and Janice E. Graham. "Technologies of Trust in Epidemic Response: Openness, Reflexivity and Accountability during the 2014-2016 Ebola Outbreak in West Africa." BMJ Global Health 4, 1 (2019): e001272.

Sen, Amartya. Poverty and Famines: An Essay on Entitlement and Deprivation. Oxford: Clarendon Press, 1981.

Shah, Nayan. Contagious Divides: Epidemics and Race in San Francisco's Chinatown. Berkeley, CA: University of California Press, 2001.

Sinha, Michael S. and Wendy E. Parmet. "The Perils of Panic: Ebola, HIV, and the Intersection of Global Health and Law." American Journal of Law and Medicine 42, 2-3 (2016): 223-255.

Smith, Julia. "Overcoming the 'Tyranny of the Urgent': Integrating Gender into Disease Outbreak Preparedness and Response." Gender and Development 27, 2 (2019): 355-369.

Tilly, Louise A. "Food Entitlement, Famine, and Conflict." Journal of Interdisciplinary History 14, 2 (1983): 333-349.

Wenham, Clare, Julia Smith, Sara E. Davies, Huiyun Feng, Karen A. Grépin, Sophie Harman, Asha Herten-Crabb and Rosemary Morgan. "Women Are Most Affected by Pandemics: Lessons from Past Outbreaks." Nature 583 (2020c): 194-198.

Wenham, Clare, Julia Smith and Rosemary Morgan. "COVID-19: The Gendered Impacts of the Outbreak." The Lancet 395, 10277 (2020a): 846-848.

Wilkinson, Annie and James Fairhead. "Comparison of Social Resistance to Ebola Response in Sierra Leone and Guinea Suggests Explanations Lie in Political Configurations Not Culture." Critical Public Health 27, 1 (2017): 14-27. 


\section{Bridging the gap \\ Epidemics, public health workers, and "heroism" in cinematic perspective}

As the struggle with COVID-19 continues to go on, one feature of the societal response has been the appearance of a militaristic terminology — often drawing parallels with war scenarios. The general public, media, and government authorities alike have framed the interaction with the pathogen as a battle against an "invisible enemy", and one led by "key workers" operating on the "frontline". We have heard references to a country's "darkest hour"- - echoing British Prime Minister Winston Churchill during the Second World War-and the ringing out of Vera Lynn's We'll Meet Again and the Italian anti-fascist folk song Bella Ciao. Of course, the metaphorical use of war to depict the struggle against disease is not new with COVID-19, but has a long history (Hanson, 2008; Flusberg et al., 2018), and was seen recently in terminology employed during Ebola outbreaks in Western Africa, with reference to "Ebola soldiers" and "plague fighters" (Roy et al., 2021: 81). Militaristic terminology, furthermore, has been supported visually through the representation of health workers in hazmat suits - not only emphasizing existential risk, but notions of security and defense (entrenched historically: Lynteris, 2018b).

As a result, it is perhaps unsurprising that alongside this militaristic terminology, we have also seen "heroism" become a prominent global motif-together with an associated language of traitoring and dereliction of duty. On 22 April 2020, the BBC even led with an article posing the question "Will Coronavirus Change How We Define Heroes?" (Anon., 2020c), and scholarly literature, well before COVID-19, had already suggested that the threat of pandemics would, in future years, reinvent the ways in which we consider both terror and heroism (Schweitzer, 2019). While in previous years more significance has been placed on the cultural trope of the "superhero", or the "great public figure" such as Martin Luther King or Nelson Mandela (for an overview see Allison and Goethals, 2011), the emphasis during COVID-19 has turned to acts of heroism from belowessentially ordinary people doing their everyday jobs in healthcare, transportation, or food provisioning, helping strangers, but under stressful, pressurized, and traumatic conditions, and with great risks to their own personal health and safety. This is perhaps nowhere better illustrated than in the public statement on Twitter from the Vice President of the United States, Kamala Harris, on 19 January 2021, where she declared she had "a message for all the little girls and boys out 
there who dream of growing up to be superheroes: Superheroes walk among us. They're teachers, doctors, scientists, vaccine researchers - and you can grow up to be like them too" (2021). Similarly, "whistleblowers"-those revealing institutional or professional malpractices, or simply supplying new pieces of information, often with personal risks involved - have also been presented as forms of "quiet" heroism (for the concept: Brown, 2017). Accordingly, these acts are viewed as distinct from general "prosocial" forms of compassion or altruism (on their blurred lines: Franco et al., 2011). It must be noted, furthermore, that similar developments were seen during Ebola outbreaks in Western Africa in 2014-2015, where "hero status" among communities was attributed more to "ordinary insiders", perhaps unsung, rather than altruistic interference from outside (AtlaniDuault et al., 2020; Roy et al., 2021).

From these developments, a new ethical debate has arisen. On the one hand, this reframing of the term "heroism" might be viewed positively-giving newfound recognition to "forgotten" or underappreciated members of society. This could have broader egalitarian consequences - a greater respect for those with lower socio-economic status, and in the context of public health, a greater respect for the social, economic, and cultural contribution of migrants, which is of obvious significance given the recent rise of populist governments all across the world standing on the back of nationalism and xenophobia. Furthermore, it has been shown that the majority of "key workers" employed in public health or caregiving roles during COVID-19 are women (Wenham et al., 2020a, 2020c)—perhaps altering a reliance on macho ideals of bravery or courage, to a "relational heroism" that, according to psychology professor Alice Eagly, "is much less dramatic and more personal, that's not necessarily a sudden act but is more of a continual commitment" (Anon., 2020c).

On the other hand, the reframing of the term "heroism" might also be viewed negatively. Many public health workers, for example, have had little choice in the matter and continue to work while frightened or over-burdened-sometimes while having sub-optimal access to requisite protective clothing (particularly in the initial stages of the outbreak). In a BBC television program, Panorama, which was shown during the first spike in COVID cases, one health worker explicitly stated that "Calling us heroes just makes it okay when we die" (Anon., 2020d). Furthermore, during the second spike in cases, more attention was put on the deleterious long-term impact on the mental health of those in the medical and caregiving professions. In other words, glorifying their work - and creating assumed fixed notions of medical duty - might be highly unethical at this time. Contemporary and historical work on the subject of "who must act" and "what risks must be accepted" has already pointed to the temporal and political fluidity of medical ethics during epidemic outbreaks (Wallis, 2006; Malm et al., 2008). Veneration of heroes, furthermore, may simply be symptomatic of different processes going on. During previous outbreaks of MRSA in the United Kingdom it was suggested that the symbolic centralization of institutions such as the NHS simply reflected fear driving nostalgia for an earlier perceived age of order and hygiene (Washer and Joffe, 2006). 
Perhaps at the most cynical level, it might also be argued that the widespread veneration of new forms of heroism in both the media and among the general public provides a veneer of protection for authorities and governments: their own failures obscured or hidden behind a façade of good will and empathy. In one high-profile case from the United Kingdom, an elderly war veteran's laudable attempts to raise funds for the NHS were lauded as "heroic", while the "hero" himself, Captain Sir Thomas Moore, in turn described the NHS staff as the "real heroes" of the "front line". Yet some might argue that media emphasis on emotive stories of giving and compassion deviate public attention from other issues such as long-term structural underfunding of public health in the United Kingdom or underlying institutional dysfunction. "Heroization" might also be a deliberate strategy employed by authorities to appease and placate workers-symbolic and superficial recognition rather than material and financial (Desmond, 2008). Furthermore, tense stands-offs in many mid-western states of the United States of America between protesters against lockdowns and counter-protesting medical workers only serve to highlight the fragile or insecure foundations in which the new "ordinary hero" image is conceived. In May 2020, The Economist led with an article titled "Health Workers Become Unexpected Targets during Covid19": noting that beyond the cheers, applause, and pictures of rainbows, public health workers have also been subject to violent and psychological abuse (Anon., 2020e). Indeed, during the second/third spike of infections in parts of the West, some people have decided to take to social media such as Twitter to question whether medical staff "really are so burdened?", but in the process sharing dubious and poorly contextualized photographs of "empty" hospital corridors.

The role of the media and popular culture in helping forge societal conceptions of what it means to be a hero is, therefore, clearly important. However, just as described earlier with COVID-19, there is also a debate on the effectiveness and ethics of their educational function-perhaps illustrated in the burgeoning sub-field of "heroism science". Some literature has an entirely positive view: the construction of heroes in films, comics, and television, for example, may encourage young people and children into decidedly altruistic future roles. Indeed, it has even been suggested that putting healthcare personnel on the same level as superheroes such as Superman or Wonder Woman, could conceivably lead to a realignment of children's idols, and in turn encourage them towards saving lives through education, treatment, and research in adulthood (Brown et al., 2016). Anxieties associated with the visualization of graphic or depressing disease symptoms might also be contained or moderated by weaving plots around heroic medical figures (Tomes, 2002: 646). However, not all views are positive. Psychological studies have suggested that while hero images can help uplift young people, inspire hope and comfort, and support identity formation, they can also disappoint, model bad behavior, and offer unrealistic standards of comparison (Kinsella et al., 2020), as well as create incentives for taking poorly calculated risks (Becker and Eagly, 2004). Other literature has critiqued the assumption that societies create heroes for the better, concluding, when looking to the past, that historical heroes have rarely served the greater good (Sviderskyte, 2019). 
Furthermore, it is also possible that heroism is broadly conceived of in positive terms, but that does not necessarily validate explicit attempts to deliberately encourage or cultivate heroic behavior through education or messaging (Beggan, 2019). Some have suggested that contemporary society has often "overheroized" medical professionals - especially in the wealthy West - which tends to establish a narrative of the "white knight" working to "save" passive, ignorant, or incapable communities in the Global South (Roy et al., 2021: 75; Hewlett and Hewlett, 2008).

Given the three-layered debate regarding (a) the definition of the term "hero" and its fluidity, (b) the ethics of applying it in the context of public health environments, and (c) whether media and popular culture should be employed to deliberately cultivate heroic behavior, this chapter analyzes how public health workers have been represented in the cinematic portrayal of epidemic disease outbreaks. What features or characteristics are prominently foregrounded, and for which public health workers? Can they be considered "heroic", and if so, how is that achieved? This links up with the broader question of how hero images have been historically and culturally conditioned. As described already, many societies' recent and ongoing struggle with COVID-19 has led to the veneration of the "ordinary hero" within public health work - but the question remains whether this is in fact something that can also be discerned in cinematic history, or whether it is something that is a sharp departure from what can be observed in films. Accordingly, in this chapter we use a broad definition for public health workerincluding figures that could arguably be considered as elites or authorities such as doctors, scientists, epidemiologists, and bacteriologists, but also others less likely to be considered elites such as nurses, caregivers, midwives, and vaccination and transportation staff; even if these occupations clearly still require considerable expertise, knowledge, and technical skill.

Overall, the focus on public health officials' representation in cinema makes sense within a broader context of the development of the "medialization of science"- the mutual relationship between the social systems of science and the mass media. By this, it is suggested that there is in more recent times an increasing tendency to orient scientific approaches and findings towards the interests of the media, since media attention for certain topics is seen as vital for public support, research funding, and outreach and education (Weingart, 2012). In recent times, cinema has even been used to teach aspects of disease and healthcare to medical students (Darbyshire and Baker, 2012). Thus, for example, it has already been noted earlier in the book how in the film Contagion, many of the cast and crew members visited the CDC for preliminary research before filming in the interests of developing authenticity. How do developments such as this impact on processes of scientific knowledge presentation to wider audiences, and does this entrench or bring closer together "lay" and "official" perspectives on the threat of disease (Wagner-Egger et al., 2011)? Furthermore, can we see the images and representation of public health workers in high-profile films such as Contagion as generalizable and typical of visual culture's attempts to frame epidemics or simply unrepresentative and anomalous? 


\section{The unappreciated public health worker}

It has been suggested in pioneering new work at the intersection of history, cultural studies, and anthropology, that concepts such as the epidemiologist as "culture hero" in visual or popular culture have roots going back into the past, but at the same time developed or changed across the course of the twentieth century. Some of the earliest depictions of public health officials in post-Second World War American television dramas were predominantly male physicians presented as culture heroes by being stripped of their charisma - in the process fostering social cohesion through technical training and skill (i.e., the science) - rather than their own innate qualities or personalities (Lynteris, 2016a). Emphasis was put on their ability to act with dispassionate rationalization, routinization, and objectivity rather than give in to their emotions or feelings. This was some departure from the situation in the 1930s, which was more deferential (Jones, 2001, 1997), where trained doctors often had distinctive personalities and were partially integrated members of local communities themselves - establishing close relationships with many of their patients (Lederer and Rogers, 2003: 492-493). Thus, in alreadymentioned films such as Panic on the Streets, The Killer That Stalked New York, 80,000 Suspects, and Morte a Venezia, public health officials - sometimes working in conjunction with political authorities - are often found holding back certain amounts of information from the general public to maintain social cohesion and avoid panicked or extreme responses (Han and Curtis, 2020). Perhaps one feature shared between films before the Second World War and those after, however, was the persistent emphasis on medicine as largely infallible and male doctors having almost omnipotent powers (Pheasant-Kelly, 2016: 238, 241).

By the later phases of the twentieth century, however, the attribution of the term "culture hero" had changed. The epidemiologist was now the embodiment-and thus in the words of Lynteris, the "restoration" — of humanity: an interpretation that emphasizes the human qualities of the medical professional, alongside their technical skills (2016a). By this, specific reference is made to characteristics such as emotion, compassion, disobedience during times of stress brought about the threat of an epidemic, and breaking the rules to "put civil and medical duty above orders". Indeed, while in Panic on the Streets, the US Public Health Service and police agree not to notify the press of a pneumonic plague death, and the doctor is merely a sidekick to the police captain as the major lead protagonist, films such as The Crazies (George A. Romero, 1973) and Day of the Dead (George A. Romero, 1985) began to zoom in on the tensions between medical or scientific expertise and political or military authority. Accordingly, by the 1990s we began to see certain situations such as the doctor who realizes her patient has died of bubonic plague in Quiet Killer, and then acts against the authorities by attempting to warn New York's citizens - with considerable pushback and resistance from the city mayor. In other filmmaking contexts such as in Eastern Europe, the discord is less clear-instead the health workers are made prominent (as seen in the Polish film, Zaraza, based around smallpox in Wroclaw), but established within a successful alliance between medics at the ground level and authoritarian actions of state and police (Kunicki, 2021). 


\section{Bridging the gap}

This "restoration of humanity" thesis is compelling and complex, but one might also ask whether the two (non-zombie-related) films that Lynteris focuses onOutbreak and Contagion - are wholly representative of a wider pool of epidemicrelated films. Indeed, we already noted that Contagion was very unusual in the director's conscious decision to systematically integrate disease prevention and public health expertise. Overall, we also note that the heroic image of the public health worker in many other epidemic-related films often rests on other cinematic devices that center on distrust, as suggested in Chapter 3 (also, Han and Curtis, 2021d). A recurring theme running through many of these films dealing with societal responses to epidemics is the emphasis on the sacrifices made by public health workers - especially authority figures such as doctors and high-level scientists - that sometimes even lead to the ultimate self-sacrifice, where the performance of duty and responsibility to other people's well-being contributes to an untimely death. Thus, for example, in the recent high-grossing Chinese film Wolf Warrior 2, based on an epidemic outbreak of "Lamanla" in Africa (with obvious parallels to Ebola), the medic who has developed the cure, Dr. Chen (Guo Qiucheng) is shot by a guard and dies in the process of trying to protect his daughter who has developed antibodies - though not before revealing the location of other hostages with his last words. However, a key device employed within many other films is not only to merely make the audience aware of this sacrifice, but its power is found in operating in combination with the fact that the characters around the medic - broader community and society—often fail to recognize or even give cursory acknowledgment to the sacrifice.

Even in Contagion itself, already well addressed by Lynteris, this is clearly the case - with one of the most prominent examples being that of Dr. Erin Mears, an Epidemic Intelligence Officer, who begins investigating a community outbreak in Minneapolis but in the process is infected herself. Despite warnings from a colleague, she continues to concern herself more with the welfare of others, and in her final act, she is seen selflessly passing a coat to another sick person for warmth before dying, as depicted in Figure 4.1. The significance of this sacrificial scene is elevated by working in combination with other events elsewhere. A plane originally intended to evacuate Dr. Mears while alive, is diverted to pick up "important" political officials instead, which sharply contrasts with Dr. Mears's final scene where she is hastily zipped into a body bag and thrown into a mass burial site - a cold and brutal scene that emphasizes her selfless efforts that remain unacknowledged. It should be recognized that Dr. Mears is, at the very least, one of the few female "elite" public health workers displaying expertise and skill during epidemics - even if it goes unappreciated, or is to her own detriment, within the film narrative. Many negative or stereotypical film representations of women in science remain commonplace (Flicker, 2003; Steinke, 2005, 1997; Kasi Jackson, 2011; Elena, 1997), as elaborated upon further in Chapter 5-with simply incompetent, easily dismissed, or unstable female images in epidemic-related films such as Dr. Kim In-Hae (Soo-Ae) in Flu, Dr. Rachel Prescott Smith (Celina Jade) in Wolf Warrior 2, and Susan (Eva Green) in Perfect Sense - despite the attempts of several organizations that have tried to nuance and diversify the images of female 


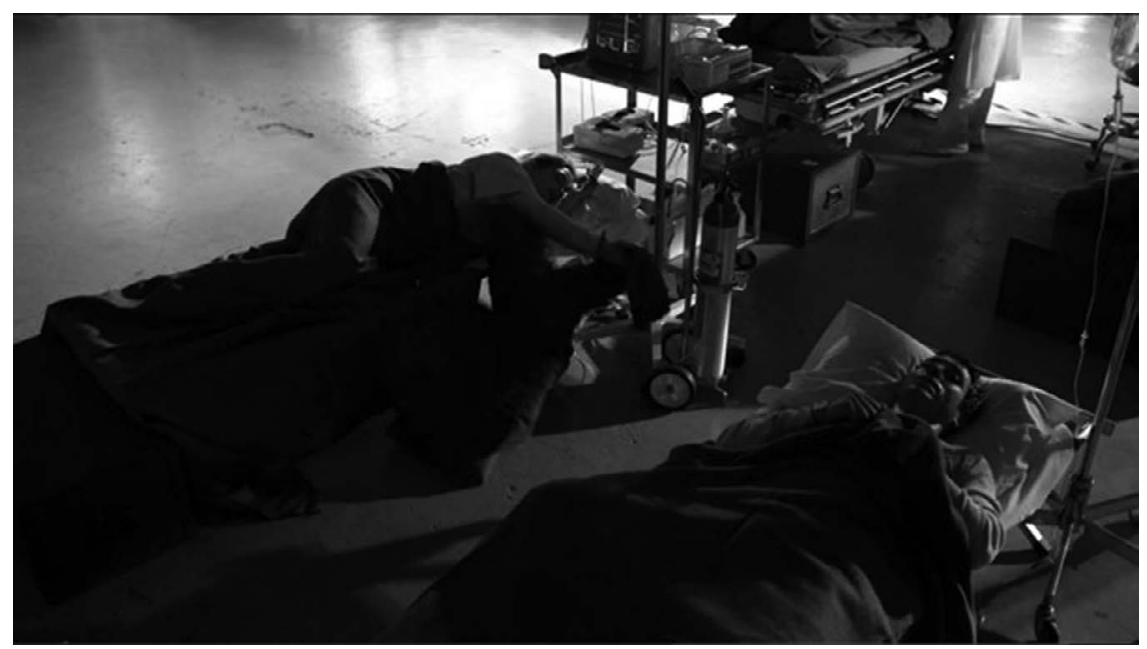

Figure 4.1 Death of Dr. Erin Mears in Contagion (Steven Soderbergh, 2011)

Source: Captured from personal copy.

health workers in entertainment, such as the Geena Davis Institute on Gender in Media and the German organization, MINTiFF (Kirby, 2017: 11).

As already suggested in Chapter 3, in other films such as The Painted Veil, the third film adaptation of a 1925 novel by W. Somerset Maugham, the central male protagonist, Dr. Walter Fane, a British bacteriologist, is seemingly presented as a heroic figure-risking his own life voluntarily in order to help bring a cholera outbreak under control in a rural and isolated area of 1920s China. This image is developed through an Orientalist imagination of a "backwards" or "primitive" Chinese village, being "saved" - in many cases from themselves - by the noble intentions of a "white knight" bringing knowledge, education, and "civility". Walter brings with him all the latest advances in "germ theory" understanding of how diseases spread, which is contrasted with the rural villagers still clinging to miasmatic principles. Much of this narrative is built upon the combination of professionalism (working late into the night with his notes), the voluntary and all-consuming nature of his work, and self-sacrifice - his final attempts to install a quarantine of new arrivals into the village leading to his grisly death from cholera in a camp, next to his grieving widow, Kitty. However, the strength of this self-sacrificial message that the film attempts to convey is only heightened when these things are combined with the lack of recognition of Walter's efforts from the village itself. Indeed, throughout the film, Walter's interventions are not well accepted by the local villagers - especially on the issue of disposal of corpses or closing off of water supplies from the communal well-and this distrust is further couched within a broader framework of nationalistic fervor (set within the context of the anti-imperialist May Thirtieth Movement set off after the Shanghai 


\section{Bridging the gap}

Municipal police shot and killed a number of Chinese protesters) which leads to violent threats against himself and his wife (Han and Curtis, 2021d). Indeed, the only time that the Chinese villagers are brought into the viewer's consciousness is during mass collective resistance-reflective of a homogenous whole rather than considered as individual agents - with faces contorted in anger at the foreign bacteriologist's apparently nonsensical interventions (compare Figures 4.2 and 4.3).

This even has some parallels with the first film adaptation produced in 1934 (Richard Boleslawski) - more than 70 years beforehand - where Walter (Herbert Marshall) is stabbed during a protest from villagers who are understandably upset at the prospect of having their homes burned to the ground to guard against infection. Predictably couched in imperialist fantasies and crude stereotyping, Dr. Fane is revered to an even greater degree in this first 1930s screen adaptation - towards the end of the film noted as giving his life's work, and yet being continually rejected by the "ungrateful" local populace.

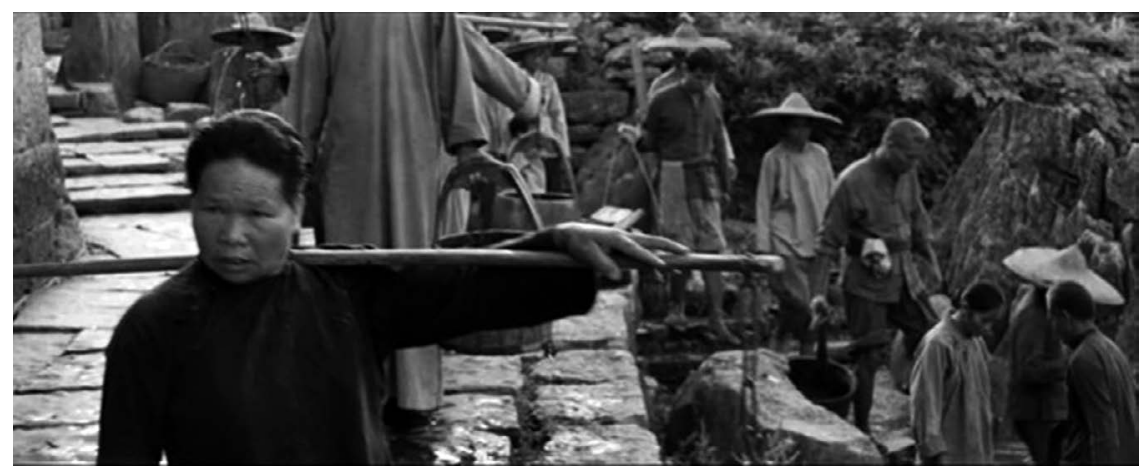

Figure 4.2 Village discontent at the water well in The Painted Veil (John Curran, 2006)

Source: Captured from personal copy.

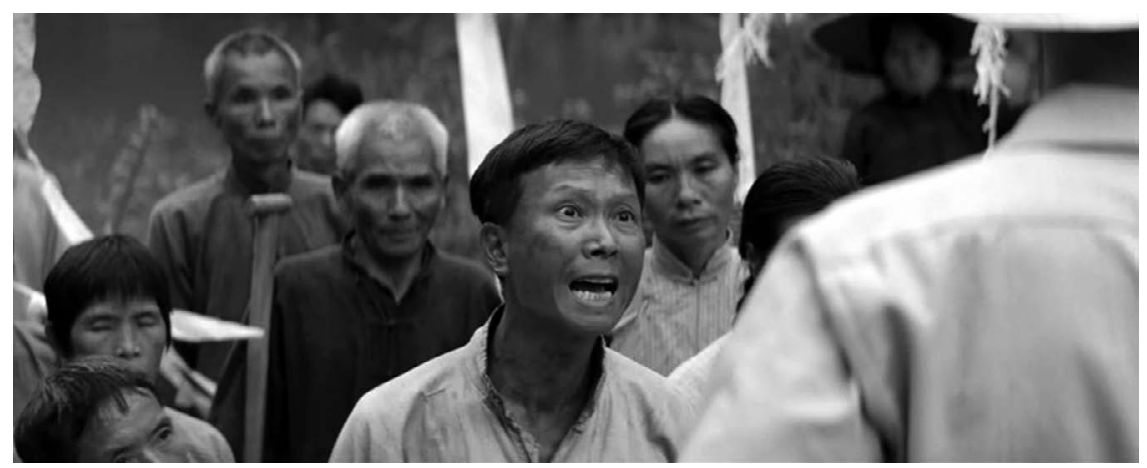

Figure 4.3 Anger at the burial grounds in The Painted Veil (John Curran, 2006)

Source: Captured from personal copy. 
Indeed, this very same distrust of the intentions of medical authorities has been shown in very different types of films - from those dramatizing the lives of real medical figures to those presenting the most fantastical and unrealistic zombie infection scenarios. Of the first kind of film, we can point to both older and more recent films from China such as 神医扁鹊 [Shen yi bian que] (Yin Cui, 1985) and 大明劫 [Daming jie/Fall of Ming] (Jing Wang, 2013), about real-life physicians Bian Que (c.401-c.310 BCE) and Wu Youke (1582-1652 CE), respectively, whose ideas were initially rejected by both political and military authorities and ordinary communities. For the second kind of film, we can point to the events depicted in the American film Dawn of the Dead, which presented Dr. Millard Rausch (Richard France) as decidedly unempathetic and strictly logical — and accordingly in the process coming into heated arguments with media personalities and ordinary people. In other cases, it is not lack of empathy per se, but the inability to articulate ideas, thoughts, and feelings. For example, in the Japanese film, 感染列島 [Kansen rettô/Pandemic] (Takahisa Zeze, 2009), a medical officer from the WHO, Dr. Eiko Kobayashi (Rei Dan), may be devoted and professional (also self-sacrificially dying in the end) _ but she is also presented as a poor communicator, coming into conflict with other doctors from the local hospital, and failing to explain procedures and practices to patients - thus appearing abrupt and cold. And returning to Dr. Walter Fane in The Painted Veil, he may be selfless and professional-self-sacrificial even - but this is combined with arrogance that directly leads him into conflict with the villagers, with an army general, Colonel $\mathrm{Yu}$, with a local warlord (a relationship that needed to be mediated by Colonel $\mathrm{Yu}$ ), and perhaps most tellingly with his own wife throughout much of the film.

Yet, we should also note that these themes are not confined only to public health officials, and moreover, such resistance is not always a product of poor communication. For example, the film Monsieur Vincent (Maurice Cloche, 1947) also tells the story of the real-life Catholic cleric Vincent de Paul, working in the early seventeenth century, whose acts of true compassion and understanding towards poor plague sufferers are met by physical resistance - the opening scenes of this film showing villagers angrily throwing stones at him. Similarly, in the Le Hussard sur le toit, based on a nineteenth-century outbreak of cholera in the Alpes-de-Haute-Provence region of southern France, the Italian noble, Angelo Pardi (Olivier Martinez), throws himself into the battle against the disease- - seen as a metaphor for the ongoing war and the lack of meaning put on human life. Yet his efforts are all in vain, and even misinterpreted by the local residents who viewed him as a "corbeau" (greedy or avaricious type) (Cauville, 2014: 58).

This initial outright rejection of a doctor's theories or hypotheses-especially regarding the origins of an epidemic disease outbreak - have also had a very long role in cinematic history. For example, in Yellow Jack (George B. Seitz, 1938), the film dramatizes the real-life events concerning the attempts to diagnose and deal with yellow fever-zooming in on Dr. Carlos Finlay (Charles Coburn) and the discreditation of his theory that it was caused by the bites of infected Aedes aegypti mosquitos. Two years later, in Dr. Ehrlich's Magic Bullet, comparable distrust and lack of peer support is seen in the dramatization of Dr. Paul Ehrlich's 
(Edward G. Robinson) real-life experimentation with the injection of chemicals into the blood to fight infectious diseases such as tuberculosis, diphtheria, and syphilis (Lederer and Parascandola, 1998). Similar breakdowns in the relationship between medic and community can be seen in the earlier film of Doctor Bull, however, in this case, with important twists. Here, the members of the small New England community hold a formal meeting and decide to replace the "oldfashioned" physician (Will Rogers) with a new doctor "from outside" - in the context of local gossip about Dr. Bull's close relationship with a local widow (Vera Allen) and a disturbing outbreak of typhoid fever. Elsewhere, in A Man to Remember (Garson Kanin, 1938), a remake of One Man's Journey produced just five years earlier (John S. Robertson, 1933), Dr. John Abbott (Edward Ellis) is unable to convince important local figures to cancel the county fair, on the grounds of a likely outbreak of polio - and by breaking the rules is suspended by the county medical association. Only later is Dr. Abbott proved right about the epidemic - recognized by the community for his humanitarian work, but by this time, he has died peacefully in his bed.

The same devotion to duty-ultimately unrecognized-was also seen in acclaimed Japanese director, Akira Kurosawa’s 1949 film, 静かなる決闘 [Shizukanaru kettō/The Quiet Duel]. During the Second World War, the young idealistic Dr. Fujisaki (Toshiro Mifune) becomes accidentally infected with syphilis himself while treating a patient (Kenjiro Uemura), and thereafter, spends the rest of the film trying to eradicate the disease, but also distancing himself from those close to him, without explanation. In the end, his wife, Misao (Miki Sanjo), becomes the fiancé of another man, and although makes one last attempt to reconcile with Dr. Fujisaki, he continues to reject her-sacrificing his own relationship for professionalism and continuing to not reveal his condition. Kurosawa uses the circumstances of the patient - the man who inadvertently infected Dr. Fujisaki-as a contrast to the medic's "saintly" silent sacrifice. He gives syphilis to his wife, leading to the death of their infant child. Indeed, the film reaches its climax with the original patient, Takata, returning to the hospital in a drunken, desperate, syphilis-infected frenzy.

Thus, the self-sacrificial representation of public health workers within epidemicsrelated films often has tended to be established on the back of their efforts being unrecognized by other film characters - and in many cases an active level of distrust or disagreement. Accordingly, it is important to also note that the "ordinary heroes" recognized today during COVID-19 have rarely made an appearance in films about epidemics - indeed, nurses, vaccination workers, and caregivers have not generally been placed at the center of the narratives during any period of cinematic history. Thus, in the aforementioned Yellow Jack, for example, the dramatization of real-life events concerning the diagnosis and treatment of yellow fever, the film fails entirely to show the death of trialist Clara Maas, an ordinary nurse, who volunteered under the false impression of immunity (Wijdicks, 2020: 74). The public health worker in the cinematic context has remained the preserve of the authority or the elite figure, frequently male, and in fact, if anything, one of the key devices within many of these films tends to be that the communities from 
below (who are generally not public health workers) often are presented in opposition to, or at least very different to, the attitudes, values and beliefs of the professional physicians, bacteriologists, or epidemiologists that tend to come from "outside". However, in the next section, we suggest that one way in which these types of more elite medical professionals come closer to the "ordinary community" in some films is through their flaws or limitations - thus becoming "more human" as a result.

\section{Narrowing the gap in public health: elites becoming "ordinary"}

Although scientists are increasingly portrayed as "good" or "decent" in visual and popular culture, there still remains a tendency to mark their characters out as eccentric and socially awkward - social attributes perhaps once considered negative in many contexts, but nowadays less obviously so (Kirby, 2017; Flores, 2002; Frayling, 2005; Haynes, 2017; Weingart et al., 2003). In some cases, this is even turned into a positive. In films concerning epidemics, public health officials have, at times, become mavericks - see, for example, the courageous and principled determination of Outbreak's Sam Daniels (Dustin Hoffman) under pressure from bureaucratic forces from above (Lynteris, 2016a). Indeed, although "ordinary heroes" in public health are rarely foregrounded in cinema, what is more often the case is that elite or authority public health workers with specialist expertise - doctors, scientists, epidemiologists, and so on - acquire characteristics and traits that bring them closer to the ordinary, and sometimes exposing their personal vulnerabilities (Daher-Nashif, 2021).

One way in which epidemic-related films have done this is by employing a frequent narrative device that includes the elite medical professional's personal recognition of error or guilt - and the feeling of culpability generated from it. This kind of self-conscious critique of the moral and ethical practices can be seen in The Andromeda Strain, where in one scene a laboratory worker, Dr. Jeremy Stone (Arthur Hill), exclaims, "We're not here to make accusations! We have a job to do, purely as scientists", and yet is countered by his colleague, Dr. Ruth Leavitt (Kate Reid), who skeptically replies: "Maybe not so pure". Elsewhere, in the already-mentioned Pandemic, Dr. Tsuyoshi Matsuoka (Satoshi Tsumabuki) feels a personal responsibility to be on the frontline at the hospital to deal with the virus, since he treated the first patient—initially misdiagnosing it as just a "common cold". The same can be seen in Contagion, where the director of the CDC also takes direct responsibility for perceived mistakes - accepting with humility the investigation into his behavior, after he had told his fiancée to evacuate before announcing it publicly. However, it should also be noted, that Dr. Cheever himself explicitly declares that he would do the very same again - given the optionwhich accords very closely with Lynteris's emphasis on the importance of certain "human qualities" that extend beyond basic technical skills. Dr. Cheever is also found rectifying self-determined failures to stick to his basic moral code. At the end of the film, he gives up the right to an early vaccine, instead swapping his wristband with a small boy from a poorer family further down the list-likely 
because of guilt over a hasty or dismissive exchange with the boy's father (a janitor at the hospital) earlier in the film. Although tempting to see the medic's willingness to break the rules as something very modern, similar scenes can be picked out even from pre-Second World War films such as Dr. Ehrlich's Magic Bullet, where Dr. Ehrlich is effectively dismissed by his hospital for his disregard for regulations tied up in bureaucracy, or Dr. Bull in Doctor Bull, who decides to steadfastly stick to his own principles rather than bow to social pressures or administrative precedents.

Indeed, this conception of the public health official becoming closer to the ordinary may even have its roots in earlier films about epidemics, where the outbreak of a deadly disease becomes the context behind the personal redemption of a medic - bringing them out of the "darkness" and closer to their "original calling" as someone devoted to tending to the sick, and in the process presenting public health practice as an intrinsically honorable task. In Les Orgueilleux, a FrancoMexican co-production nominated for an Academy Award, and adapted from previous work by Jean-Paul Sartre, ${ }^{1}$ the story centers on a doctor (Gérard Philippe) in the miserably depicted town of Alvarado, southern Mexico, who has essentially abandoned himself to drink and depression. The moral degradation of the doctor is epitomized by the fact that he had operated on his wife during childbirth, while under the influence of alcohol, leading to her death. In line with many of the existentialist disease-society cinematic presentations of the post-Second World War period that display angst or pessimism over social values, and reflect upon the strengths or weaknesses of human relationships (as elaborated upon in Chapter 2), the dejected doctor questions life itself and its callous meaninglessness. However, his moral redemption lies in the epidemic outbreak itself - apparently meningitisgiving him new cause to respond to the needs of the vulnerable around him, and his rebirth is complete when he decides to resume practice (building a makeshift infirmary to treat the afflicted) and finds love in the arms of the female protagonist, Nellie (Michèle Morgan), who herself, had lost her husband to the disease.

Although less extreme, a similar course of events can be traced in 1930s films such as Arrowsmith, based around an outbreak of bubonic plague on a fictional Caribbean island. In the beginning, the key protagonist, Martin Arrowsmith (Ronald Colman), is keen to use his knowledge with a particular cow serum to help humanity, but in the process loses his way. By only treating half the native population to test its effectiveness (with a clear racialized discourse, given that the experimental test is only carried out on the Black population)-Arrowsmith loses his colleague, Gustav Sondelius (Richard Bennett), and his own wife, Leora (Helen Hayes), to the disease. Only the trauma of these events pushes Arrowsmith back to his roots: abandoning scientific regulations to simply treat the whole population, saving many lives, and in the end quitting the formal institute, to join his friend Terry Wickett (Russell Hopton) in a small-scale laboratory to do "real" research. This narrative is further exemplified by the fact that at the beginning of the film, Arrowsmith had already declined a prestigious research role to follow his heart and setup a small practice in his wife's tranquil rural home town (García Sánchez and García Sánchez, 2005). Accordingly, while many of the post-Second 
World War films may have presented senior physicians as stern, detached, and without charisma, this pre-war film brought the educated medic closer to humanity by returning to his humbler roots.

The course of this story has parallels with another contemporaneous film by the name of Green Light (Frank Borzage, 1937), where a surgeon (Errol Flynn) is on the verge of career ruination after a botched operation and dismissal from a hospital. An outbreak of Rocky Mountain spotted fever serves as the vehicle behind the redemption of Dr. Newell Paige - almost dying when subjecting himself to a vaccine only in the experimental stages, and eventually convincing local religious authorities about the true nature of the disease. And this same trajectory was seen in the British film, The Citadel, where during a battle with tuberculosis, Dr. Andrew Manson becomes seduced by the lure of money treating rich hypochondriacs, and only the tragic death of his diligent and ethical friend, also a doctor, convinces him to return to more meaningful work treating poor patients living in squalor (McKibben, 2008). Once again, as in The Proud and the Beautiful, it is the intervention of the male doctor's wife, Christine (Rosalind Russell), that acts as the instigator for pushing Dr. Manson back onto his original or "proper" path - a recurring trope that we deal with at great length in Chapter 5 on gendered responses to epidemics in films.

It should be noted that those medics that fail to "narrow the gap" between the elite and the ordinary tend to be presented in epidemics-related films as the failures of the story. In Blindness, elaborated upon more fully in Chapter 3, the main male protagonist and medical authority, the ophthalmologist played by Mark Ruffalo, is presented in decidedly negative terms. When thrown into the isolation facility along with a host of other infected characters, as an educated medic, he begins the film as his own ward's "official representative" on the grounds of knowledge and power. However, as the conditions within the facility worsen over time, with no apparent hope of reprieve, his place within the institutional hierarchy diminishes, becoming usurped by a host of other - mainly female - characters, and especially by his own wife, who has retained her sight. His fall from grace is completed when he is found having extra-marital sex with a woman presented as an escorta moral failure given that his wife has spent most of the film helping and supporting him and others - and only exacerbated further by the forgiveness shown by the wife. In Figure 4.4, we see the embrace of the two women-offering support, comfort, and consolation - and thus not only reinforcing the "caring wife" image, but also a form of sisterhood, while the male ophthalmologist is presented as an outsider on the periphery. Indeed, the case of the female usurpation of the male ophthalmologist in Blindness has resonance with other recent research into the gendered culture of scientific competence-where the ineffectual male scientist is portrayed as experiencing a process of emasculation (Orthia and Morgain, 2016).

In some cases, this issue of failing to "narrow the gap" between elite figures and ordinary populations is visualized in film by contrasting the fortunes of two different medical officials. A good example of this can be seen in the Yugoslavian film Variola vera, which was based around a dramatization of a real smallpox outbreak in a Belgrade hospital in 1972. Within the confined and oppressive environment 


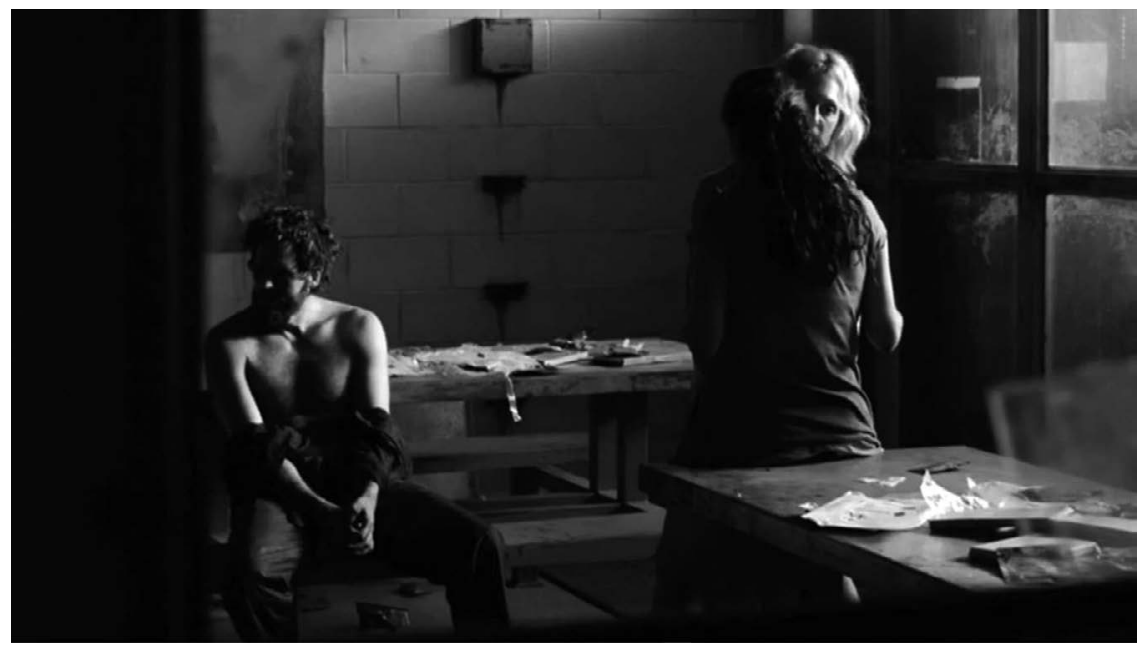

Figure 4.4 "Sisterhood" in Blindness (Fernando Meirelles, 2008)

Source: Captured from personal copy.

of the General Hospital, we see the administrator of the hospital (Rade Markovic), an authority in normal times, has significant moral flaws and limitations in expertise, while another medic, Dr. Grujic (Rade Serbedzija), viewed with skepticism in normal times, is shown during the epidemic to be unorthodox, and yet responsible, skilled, and courageous. Here, the epidemic is used as an instrument to flip the usual hierarchy.

\section{Conclusion}

When returning to the themes discussed at the beginning of Chapter 4, we may ask ourselves which public health workers are at the center of films focusing on epidemic disease outbreaks, what features or characteristics are frequently highlighted, and can we consider them as heroic - and if so, why? Overall, we realize that the "ordinary hero" image perpetuated during the COVID-19 pandemic (particularly during the early phases) - culminating in the veneration of nurses, care-workers, and even whistleblowers - is not something directly discernible in the depiction of social responses to epidemics in film; neither in the distant past, modern history, nor as a contemporary trend. Perhaps the only exception to this are more recent films based on real life cases - one example being Virus (Aashiq Abu, 2019) - that pays tribute to the wider community of medics, hospital staff, and volunteers that dealt with the Nipah virus outbreak in Kerala, India, in 2018. However, generally, the main public health workers foregrounded at the center of film narratives are epidemiologists or physicians defined by their expertise or technical ability, and often are found to be offering professionalism or sacrifice 
that goes unrecognized by broader society - or perhaps even directly challenged or dismissed. The motif of self-sacrifice despite underappreciation becomes a key component of their heroic portrayal. In contrast to the contemporary feminization of the medical profession (Ramakrishnan et al., 2014; Shannon et al., 2019; Phillips and Austin, 2009), many of the "expert heroes" in epidemic-related cinema are men, while women instead are instrumentalized within the films as ways of reminding these men about their "original calling" or set them on the "straight and narrow" and a path towards regaining respectability and reputation. Nevertheless, it should also be noted that in more recent films - of the past 25 yearsmore female doctors have appeared in cinematic depictions of epidemic settings (Daher-Nashif, 2021), and often found making first diagnoses or staying to treat patients (see the "sacrificed" female image in Chapter 5).

Accordingly, if there are "heroes from below" in these films - more in line with the COVID-19 experience thus far-they generally do not belong to the broader category of public health worker consisting of nurses, midwives, and other forms of caregiver. Instead, the favorable popular images in epidemics-related films often resides within the personal characteristics of medics themselves - frequently (though not exclusively) male expert epidemiologists, physicians, and bacteriologists showing a human side of themselves that goes some way to bridging the gap between elite and ordinary. Interestingly, their expertise sets these figures aside as "deviants" when working within communities-Dr. Walter Fane in The Painted Veil is a case in point - and yet, these communities start to accept this difference when these elite or expert figures start to make concessions. In older films this manifested itself in personal redemption, a humbling, or even a physical return to the ordinary, localized, small town or rural roots - a "simpler" more "natural" or "authentic" environment discussed at greater length in Chapter 6-while in more modern films this could range from recognition of personal error, questioning of official regulations, bureaucracy, and authorities, or forms of eccentric or unorthodox behavior that deviate from the status quo. It remains to be seen whether COVID-19 will lead to the foregrounding of new types of public health hero in cinema in the following years: that is to say, whether we see a departure from the cinematic public health hero who is a doctor or other kind of expert, self-sacrificing, and overwhelmingly male, to one more in line with the "ordinary hero" that we are seeing, at least for the most part, venerated today. At the time of writing, a new extended one-off drama has appeared on British television, Help (Jack Thorne, 2021), which, among other themes, emphasizes vulnerabilities exposed within care homes during the initial outbreak of COVID-19, and the difficult decisions that (overwhelmingly female) social care-providers had to make within a background of political incompetence and institutional dysfunction.

\section{Note}

1 Luis Buñuel, director of the pseudo-documentary on culture, society, and disease in an impoverished mountain area of western Spain, Las hurdes: Tierra sin pan (discussed in Chapter 6), and famous in his early years for avant-garde surrealist filmmaking, appears 
in this film as a supporting character-one of the gangsters belonging to the local Don. Buñuel might have been influential in the framing of the fight against the epidemic in the dilapidated town.

\section{References}

Allison, Scott T. and George R. Goethals. Heroes: What They Do and Why We Need Them. Oxford: Oxford University Press, 2011.

Anon. "Will Coronavirus Change How We Define Heroes?" BBC News, April 24, 2020c, www.bbc.com/worklife/article/20200422-will-coronavirus-change-how-we-define-heroes.

Anon. "Lockdown UK." BBC, March 30, 2020d, www.bbc.co.uk/iplayer/episode/m000h514/ panorama-lockdown-uk.

Anon. "Health Workers Become Unexpected Targets during Covid-19." The Economist, May 11, 2020e, www.economist.com/international/2020/05/11/health-workers-becomeunexpected-targets-during-covid-19.

Atlani-Duault, Laëtitia, Jeremy K. Ward, Melissa Roy, Céline Morin and Andrew Wilson. "Tracking Online Heroisation and Blame in Epidemics." The Lancet Public Health 5, 3 (2020): e137-e138.

Becker, Selwyn W. and Alice H. Eagly. "The Heroism of Women and Men." American Psychologist 59, 3 (2004): 163-178.

Beggan, James K. "On the Downside of Heroism: Grey Zone Limitations on the Value of Social and Physical Risk Heroism." Heroism Science 4, 2 (2019): 1-35.

Brown, A.J. "Whistleblowers as Heroes: Fostering 'Quiet' Heroism in Place of the Heroic Whistleblower Stereotype." In: Scott T. Allison, George R. Goethals and Roderick M. Kramer (eds.), Handbook of Heroism and Heroic Leadership, pp. 356-376. New York: Routledge, 2017.

Brown, Brandon, Melissa Nasiruddin, Alejandra Cabral and Melissa Soohoo. "Childhood Idols, Shifting from Superheroes to Public Health Heroes." Journal of Public Health 38, 3 (2016): 625-629.

Cauville, Joëlle. "Structures mythiques dans 'Le Hussard sur le toit' de Jean Giono." Dalhousie French Studies 101 (2014): 53-61.

Daher-Nashif, Suhad. "Doctors' Challenges During Infectious Disease Outbreaks: Medical Education Insights from Realistic Fiction Movies." Advances in Medical Education and Practice 12 (2021): 265-272.

Darbyshire, Daniel and Paul Baker. "A Systematic Review and Thematic Analysis of Cinema in Medical Education." Medical Humanities 38, 1 (2012): 28-33.

Desmond, Matthew. "The Lie of Heroism." Contexts 7, 1 (2008): 56-58.

Elena, Alberto. "Skirts in the Lab: Madame Curie and the Image of the Woman Scientist in the Feature Film." Public Understanding of Science 6, 3 (1997): 269-278.

Flicker, Eva. "Between Brains and Breasts-Women Scientists in Fiction Film: On the Marginalization and Sexualization of Scientific Competence." Public Understanding of Science 12, 4 (2003): 307-318.

Flores, Glenn. "Mad Scientists, Compassionate Healers, and Greedy Egotists: The Portrayal of Physicians in the Movies." Journal of the National Medical Association 94, 7 (2002): 635-658.

Flusberg, Stephen J., Teenie Matlock and Paul H. Thibodeau. "War Metaphors in Public Discourse." Metaphor and Symbol 33, 1 (2018): 1-18.

Franco, Zeno E., Kathy Blau and Philip G. Zimbardo. "Heroism: A Conceptual Analysis and Differentiation between Heroic Action and Altruism." Review of General Psychology 15, 2 (2011): 99-113. 
Frayling, Christopher. Mad, Bad and Dangerous? The Scientist and the Cinema. London: Reaktion Books, 2005.

García Sánchez, Jose Elías and Enrique García Sánchez. “Arrowsmith (1931) or Research in Microbiology." Journal of Medicine and Movies 1, 3 (2005), http://campus.usal. es/ revistamedicinacine/numero 3/ing htlm/arrowsmith.htm.

Han, Qijun and Daniel R. Curtis. "Social Responses to Epidemics Depicted by Cinema." Emerging Infectious Diseases 26, 2 (2020): 389-394.

Han, Qijun and Daniel R. Curtis. "Suspicious Minds: Cinematic Depiction of Distrust during Epidemic Disease Outbreaks." Medical Humanities 47, 2 (2021d): 248-256.

Hanson, Marta. "Maoist Public-Health Campaigns, Chinese Medicine, and SARS." The Lancet 372, 9648 (2008): 1457-1458.

Harris, Kamala. Twitter Message, January 19, 2021, https://witter.com/KamalaHarris/ status/1351643588996829196.

Haynes, Roslynn D. From Madman to Crime Fighter: The Scientist in Western Culture. Baltimore, MD: John Hopkins University Press, 2017.

Hewlett, Barry S. and Bonnie L. Hewlett. Ebola, Culture, and Politics: The Anthropology of an Emerging Disease. Belmont, CA: Thomson Wadsworth, 2008.

Jones, Robert A. "The Boffin: A Stereotype of Scientists in Post-War British Films (19451970)." Public Understanding of Science 6, 1 (1997): 31-48.

Jones, Robert A. "Why Can't You Scientists Leave Things Alone? Science Questioned in British Films of the Post-War Period (1945-1970)." Public Understanding of Science 10, 4 (2001): 365-382.

Kasi Jackson, J. "Doomsday Ecology and Empathy for Nature: Women Scientists in 'B' Horror Movies." Science Communication 33, 4 (2011): 533-555.

Kinsella, Elaine L., Alison English and Jennifer McMahon. "Zeroing in on Heroes: Adolescents' Perceptions of Hero Features and Functions." Heroism Science 5, 2 (2020): 1-45.

Kirby, David A. "The Changing Popular Images of Science.” In: Kathleen Hall Jamieson, Dan M. Kahan and Dietram Scheufele (eds.), The Oxford Handbook of the Science of Science Communication, pp. 1-18. Oxford: Oxford University Press, 2017.

Kunicki, Mikolaj. “'Medical Doctors Rule the City': Roman Załuski's Zaraza/The Epidemic and the 1963 Smallpox Outbreak in Wrocław." Apparatus: Film, Media and Digital Cultures in Central and Eastern Europe 12 (2021), http://dx.doi.org/10.17892/ app.2021.00012.253.

Lederer, Susan E. and John Parascandola. "Screening Syphilis: Dr. Ehrlich's Magic Bullet Meets the Public Health Service." Journal of the History of Medicine and Allied Sciences 53, 4 (1998): 345-370.

Lederer, Susan E. and Naomi Rogers. "Media." In: Roger Cooter and John Pickstone (eds.), Companion to Medicine in the Twentieth Century, pp. 487-502. London: Routledge, 2003 [2000].

Lynteris, Christos. "The Epidemiologist as Culture Hero: Visualizing Humanity in the Age of the Next Pandemic." Visual Anthropology 29, 1 (2016a): 36-53.

Lynteris, Christos. "Plague Masks: The Visual Emergence of Anti-Epidemic Personal Protection Equipment." Medical Anthropology 37, 6 (2018b): 442-457.

Malm, Heidi, Thomas May, Leslie P. Francis, Saad B. Omer, Daniel A. Salmon and Robert Hood. "Ethics, Pandemics, and the Duty to Treat." American Journal of Bioethics 8, 8 (2008): 4-19.

McKibben, Ross. "Politics and the Medical Hero: A.J. Cronin's The Citadel." English Historical Review 123, 502 (2008): 651-678.

Orthia, Lindy A. and Rachel Morgain. "The Gendered Culture of Scientific Competence: A Study of Scientist Characters in Doctor Who 1963-2013." Sex Roles 75, 3-4 (2016): 79-94. 
Pheasant-Kelly, Frances. "Towards a Structure of Feeling: Abjection and Allegories of Disease in Science Fiction 'Mutation' Films.” Medical Humanities 42, 4 (2016): 238-245.

Phillips, Susan P. and Emily B. Austin. "The Feminization of Medicine and Population Health.” JAMA 301, 8 (2009): 860-862.

Ramakrishnan, Aditi, Dana Sambuco and Reshma Jagsi. "Women's Participation in the Medical Profession: Insights from Experiences in Japan, Scandinavia, Russia, and Eastern Europe.” Journal of Women's Health 23, 11 (2014): 927-934.

Roy, Melissa, Nicolas Moreau, Cécile Rousseau, Arnaud Mercier, Andrew Wilson, JeanPierre Dozon and Laëtitia Atlani-Duault. "Constructing Ebola Martyrs, Warriors, and Saviours: Online Heroisation in a Context of Risk and Unease." Health, Risk and Society 23, 1-2 (2021): 73-91.

Schweitzer, Dahlia. "The New Face of Fear: How Pandemics and Terrorism Reinvent Terror (and Heroes) in the Twenty-First Century.” In: Clémentine Tholas, Janis L. Goldie and Karen A. Ritzenhoff (eds.), New Perspectives on the War Film, pp. 203-221. Cham: Palgrave Macmillan, 2019.

Shannon, Geordan, Nicole Minckas, Des Tan, Hassan Haghparast-Bidgoli, Neha Batura and Jenevieve Mannell. "Feminisation of the Health Workforce and Wage Conditions of Health Professions: An Exploratory Analysis." Human Resources for Health 17, 72 (2019): 1-16.

Steinke, Jocelyn. "A Portrait of a Woman as a Scientist: Breaking Down Barriers Created by Gender-Role Stereotypes.” Public Understanding of Science 6, 4 (1997): 409-428.

Steinke, Jocelyn. "Cultural Representations of Gender and Science: Portrayals of Female Scientists and Engineers in Popular Films." Science Communication 27, 1 (2005): 27-63.

Sviderskyte, Gražina Kristina. "For Whose Greater Good? The Case of Hero-Making: Girch and Darius." Heroism Science 4, 1 (2019): 1-24.

Tomes, Nancy. "Epidemic Entertainments: Disease and Popular Culture in Early-TwentiethCentury America." American Literary History 14, 4 (2002): 625-652.

Wagner-Egger, Pascal, Adrian Bangerter, Ingrid Gilles, Eva Green, David Rigaud, Franciska Krings, Christian Staerklé and Alain Clémence. "Lay Perceptions of Collectives at the Outbreak of the H1N1 Epidemic: Heroes, Villains and Victims." Public Understanding of Science 20, 4 (2011): 461-476.

Wallis, Patrick. "Plagues, Morality and the Place of Medicine in Early Modern England." English Historical Review 121, 490 (2006): 1-24.

Washer, Peter and Joffe, Helene. "The Hospital 'Superbug': Social Representations of MRSA.” Social Science and Medicine 63, 8 (2006): 2142-2152.

Weingart, Peter. "The Lure of the Mass Media and its Repercussions on Science." In: Simone Rödder, Martina Franzen and Peter Weingart (eds.), The Sciences' Media Connection: Public Communication and Its Repercussion, pp. 17-32. Dordrecht: Springer, 2012.

Weingart, Peter, Claudia Muhl and Petra Pansegrau. "Of Power Maniacs and Unethical Geniuses: Science and Scientists in Fiction Film." Public Understanding of Science 12, 3 (2003): 279-287.

Wenham, Clare, Julia Smith, Sara E. Davies, Huiyun Feng, Karen A. Grépin, Sophie Harman, Asha Herten-Crabb and Rosemary Morgan. "Women Are Most Affected by Pandemics: Lessons from Past Outbreaks.” Nature 583 (2020c): 194-198.

Wenham, Clare, Julia Smith and Rosemary Morgan. "COVID-19: The Gendered Impacts of the Outbreak." The Lancet 395, 10277 (2020a): 846-848.

Wijdicks, Eelco F.M. Cinema, MD: A History of Medicine on Screen. Oxford: Oxford University Press, 2020. 


\section{From spreaders to sacrifice \\ Cinematic representation of women during epidemics}

Women and girls are said to bear the harshest consequences of disasters such as floods, earthquakes, and droughts (Neumayer and Plümper, 2007), and research into recent epidemic disease outbreaks - particularly Ebola in West Africa and Zika in Brazil—has suggested much the same (Smith, 2019; Davies and Bennett, 2016; Sochas et al., 2017; Wenham et al., 2020b). Indeed, more than two-thirds of patients in the 2019 outbreak of Ebola in Congo were women, while during the same affliction in Sierra Leone from 2013 to 2016, more women died from obstetric complications than the disease itself. Although labeled a "disaster for feminism" in a recent The Atlantic piece (Lewis, 2020), it could at least be said that these issues have been foregrounded during COVID-19, as epidemics can often serve as a new window for drawing attention to forms of vulnerability, inequality, or prejudice obscured from view in "normal" times (Wenham et al., 2020a, 2020c). Despite this, however, we still suffer from a lack of a systematic analysis of societal responses to epidemics down gender lines, and moreover, a basic lack of sex-disaggregated data on how women and girls experience epidemic diseases differently to men and boys (Harman, 2016; part of a broader phenomenon in Criado Perez, 2019).

The lack of gendered analysis on how societies deal with epidemics is curious given that when we look to history-at least anecdotally-the experience of women and girls was often very different to that of men and boys in both premodern settings and modern colonial settings: from increased avenues for social control of sex workers, regulation of female attendance at burials and funerals, and persecution of female "plague poisoners" or "syphilis spreaders" (Arnold, 1993; Curtis, 2021), to women taking on various kinds of epidemic-related roles as codifiers of bodies, caregivers, cleaners, fumigators, and leading organizers of community or collective welfare provision (Curtis, 2021; Munkhoff, 1999). Furthermore, we also have evidence of women being active perpetrators of accusations and violence (Cohn, 2018: 148-149), and actively resisting oppressive authorities during epidemics (Curtis, 2021).

In Chapter 5, we try to fill a void in the lack of focused gendered analysis of societal responses to epidemics by exploring how cinema has depicted and represented the role and experience of women and girls during these outbreaksusing a wide geographical and temporal range of examples from our catalogue

DOI: $10.4324 / 9781003261667-5$ 
of twentieth- and twenty-first-century films about epidemics. Visual culture has a long historical tradition of offering deliberate gendered messages - from the early educational documentary films of the first half of the twentieth century which tried to emphasize how the battle against the microbe was something to be fought within the household - a domain presented as predominantly that of the woman (Ostherr, 2005: 4-11). Indeed, the healthy female body was often placed at the center of the concept of nationhood - a country's power and moral integrity linked at the roots to the effective family organization at the household level (Wald, 2008: 85-86; Walton, 2021; also, on the family as a microcosm of the state: Han, 2016: 22-27; Qian, 2015: 267-293).

We see cinematic analysis as a valid approach given that, as already stated, films can reflect upon the ordinary lives of citizens - especially the poor or marginalized who are perhaps most vulnerable to the various demands of a disease outbreak. Accordingly, the experience of women and girls during epidemics seen in films either represents an entrenched societal view of the gendered impact of disease within societies - shining a light on what we see within society — or even more significantly, works to help further entrench those views and values among audiences. Although scholarly literature has focused on different forms of othering during epidemics represented in film - especially down the lines of sexuality (in particular with regard to films concerning HIV and AIDS: Rees-Roberts, 2008: 89-128) and race or ethnicity (a major component of the "outbreak narrative" in Wald, 2008), epidemics-related films have yet to be systematically analyzed with regard to their presentation of the experience and role of women and girls (notwithstanding relevant earlier contributions in Wald, 2008: 68-113; Ostherr, 2005: 4-11; also important gendered work on epidemics in literature: Fisher, 2012). Recent films, however, such as Pili (Leanne Welham, 2017)_-addressing a Tanzanian woman's difficult social and economic choices in the context of HIV infection - directly reveal to us the urgency and significance of gendered analysis of epidemic responses and impact in visual culture (Harman et al., 2021).

Over the course of Chapter 5, we show that women have often been right at the center of social responses to epidemics presented in films - consciously foregrounded by directors. However, the extent, nature, and direction of these female images are quite clearly demarcated. First, we show that in films, women have often been portrayed as symbolic carriers or spreaders of disease-sometimes as a punishment - and this phenomenon is often connected to female characters seen deviating from their expected gender roles prescribed to them during epidemics. Frequently, this is tied to a moralizing view on female sexuality - termed in some literature as a "sexual epidemic" in reference to the outbreak's capacity to provide authorities with unparalleled access to bodies, and a series of codes for inscribing them with a justifying discourse (Singer, 1993: 117). Second, we show that in films, one of these prescribed roles is for women to frequently take on heavy burdens during epidemic outbreaks - often by "selflessly" caring for others. In extreme cases, this even leads to women sacrificing themselves for the "greater good" of the wider community or to protect a male protagonist. Accordingly, both images are mutually reinforcing. Although, of course, changes in nuancing of 
these two images occur over time with changes in societal values-aspects and components of them can still be observed in one form or another from the earliest films of the twentieth century to more recent productions after the year 2000. This is of interest given that medical humanities literature in recent years has pointed to the continued presence of gendered concepts of responsibility for protecting others during health crises (Godderis and Rossiter, 2013; Ribeiro et al., 2018).

\section{Epidemics and the female carrier in cinema}

It was once remarked by Kirstin Ostherr that the "invisibility of contagion" is pinned to a "concreate embodiment of "otherness" through other "potentially invisible aspects of identity, race and sexuality" (2002: 1). It is down these lines that we can understand the first representation of women during epidemics- the female carrier or spreader. The use of an image of a woman to personify a particular disease or make society more vulnerable to the outbreak of a disease has a long history. For example, in the medieval imaginary, leprous blood was linked to menstruation, supposedly discharged by impure women and believed to be a carrier of the disease (Zimmerman, 2008). Miasma-informed rationale of disease transmission also informed decisions to ban women from funerals during early modern plague outbreaks - with warnings that female presence increased the danger of contaminated air rising from the graves (Noordegraaf and Valk, 1988: 120, 134). In modern history, many related examples are strongly connected to stigmatization and prejudice. Arguably the most famous case was that of "Typhoid Mary": a term bestowed upon Mary Mallon, an Irish cook working in New York in the early part of the twentieth century, who unknowingly spread the disease in every household she worked. This term used by media and health authorities was morally coded: an unclean "fallen woman", condemned for her sexual activity and unmarried status (Echeverría, 2020; Wald, 2008: 108; also, see Figure 5.1). Focus was put on her spending evenings with a "disreputable looking man" in a room full of "filth and disorder" (Wald, 2008: 84).

Indeed, cinema itself has also reflected on the long historical connection between women and their perceived role as carriers or spreaders-often through the persecution and scapegoating of women as witches during plagues. Perhaps unsurprisingly, films based on the dramatization of original historical source material tend to avoid some of the worst problems of anachronism-for example, by screening the witch-hunting-plague connection as an early modern phenomenon (though still not a straightforward connection: Naphy, 2002). This is seen in well-known films such as Dangerous Beauty — based around the story of a sixteenth-century Venetian courtesan, who later becomes a target for a church-led inquisition when plague breaks out, and The Last Valley (James Clavell, 1971), set in the context of the political and religious struggles of the Thirty Years' War (1618-1648), where conflict and epidemics go hand-in-hand with the accusation of rural women as witches. Similar scenes are also seen in lesser-known films such as the Swedish Himlaspelet (Alf Sjöberg, 1942), where two peasants are about to marry until a disease breaks out in their village, and the 


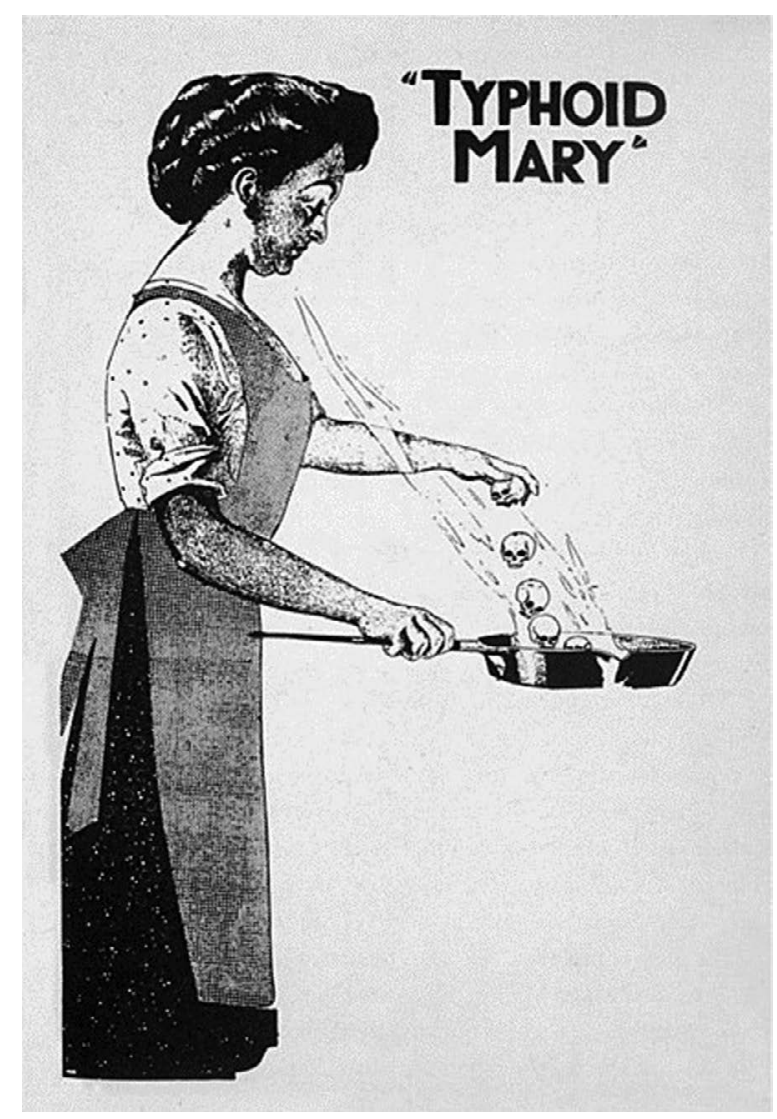

Figure 5.1 Representation of Mary Mallon, The New York American, 20 June 1909

Source: https://commons.wikimedia.org/wiki/Category:Mary_Mallon\#/media/File:Typhoid_Mary_ full.jpg [public domain].

woman, Marit (Eivor Landström), is burnt alive as the identified spreader (see Figures 5.2 and 5.3). ${ }^{1}$ In Mariken van Nieumeghen (Jos Stelling, 1974) - the first Dutch film to be entered at Cannes and based on a play written in Middle Dutch in the early sixteenth century - a woman, Marieke (Ronnie Montagne), travels from Nijmegen to Antwerp, where she is ultimately blamed for an outbreak of plague because she had cohabited seven years with the devil. Crucial to the film narrative is the persistent demand of Mariken to show repentance-in the end embarking on a pilgrimage to see the Pope in Rome, and carrying out a penance for seven years in a convent.

The links drawn between the Black Death of the mid-fourteenth century and the persecution of witches are wholly anachronistic (Black, 2019: 192), as mentioned already in Chapter 2, and yet have formed a central part of the narratives 


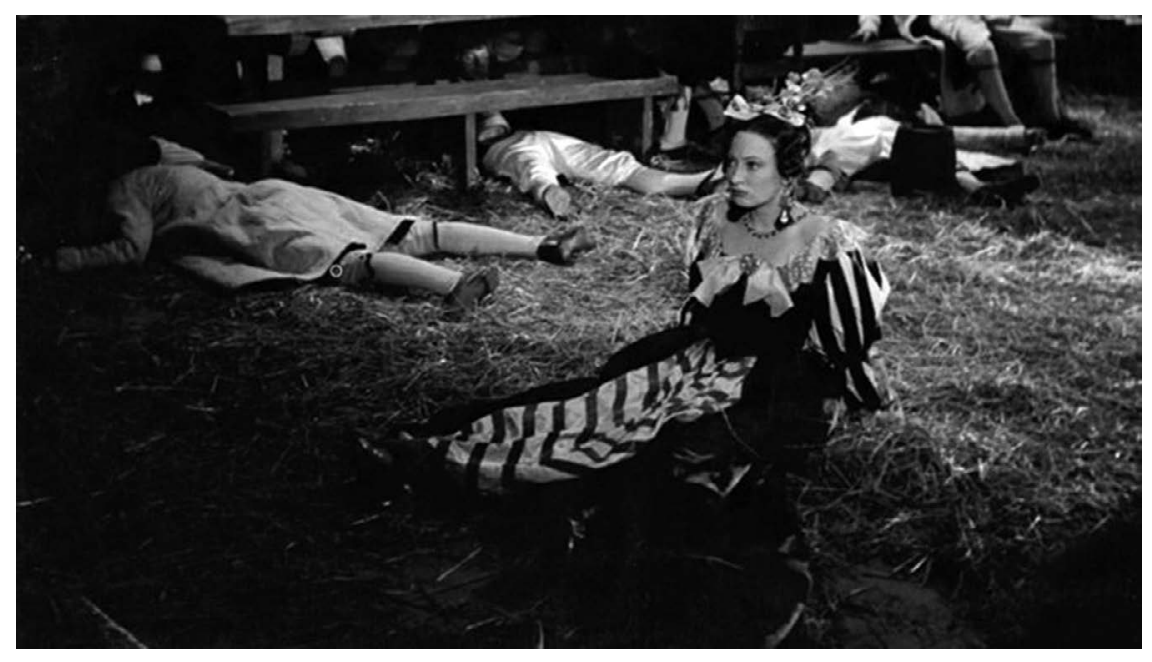

Figure 5.2 "Marit, the spreader" in Himlaspelet (Alf Sjöberg, 1942). Source: Captured from personal copy.

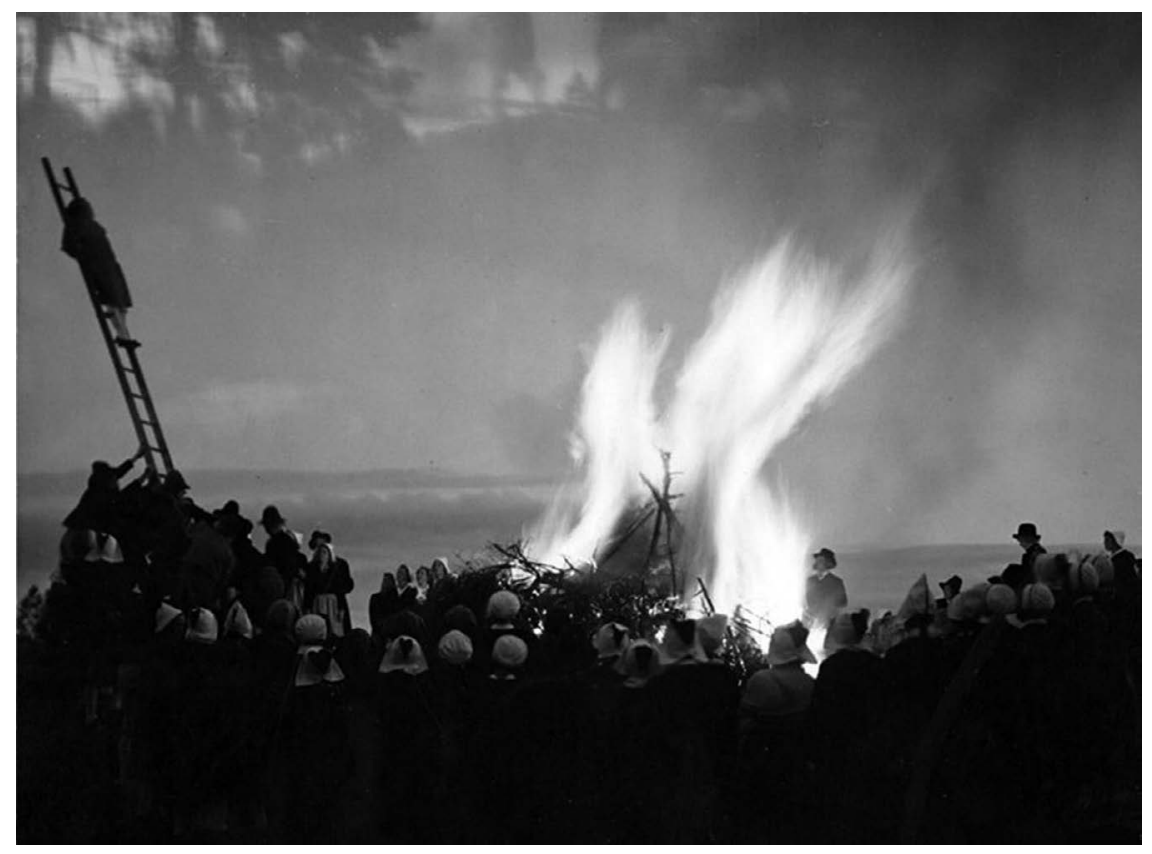

Figure 5.3 "Burning Marit" in Himlaspelet (Alf Sjöberg, 1942).

Source: Captured from personal copy. 
in critically revered films such as Bergman's The Seventh Seal, where a woman is burned for making a pact with the devil that brought a plague upon society (Larsen, 2019: 639-640), and the acclaimed British comedy Monty Python and the Holy Grail, where the accused woman is found to weigh the same as a duck, and therefore said to be made out of wood, and hence a witch. Similar trends can be seen in contemporary film. For example, in the recent Season of the Witch, a woman (Claire Foy) is explicitly accused of causing the Black Death - and as a result is forcefully escorted to an isolated monastery by two knights to explain herself (Nicolas Cage and Ron Perlman). Not only as a source of literal infection, in Black Death, the female protagonist, Langiva (Carice van Houten), as the village herbalist, is even portrayed as the catalyst for the male protagonist, Osmund (Eddie Redmayne), turning evil himself - in process seeing all women as potential witches, and misogynistically hunting them down and brutally torturing them. In one scene, we hear a tale recounted by a mercenary that " $[\mathrm{b}] \mathrm{y}$ the time that night was through, they'd killed every woman in the village. By the end of that week, the men were shagging [having sexual intercourse with] pigs" (Han and Curtis, 2021c).

It is unsurprising then that the representation of women as being at the center of potential epidemic activity has long roots in cinematic history. For example, it has been shown through the early 1924 United States Public Health Service documentary, How Disease Is Spread, that the morally inappropriate role taken by a middle-class white woman runs contrary to the prevailing view of the time that women were guardians of the private sphere - and thus the front line against public health crises that could threaten the nation (Ostherr, 2005: 4-11; on masculinity, patriotism, and personal responsibility in early twentieth-century epidemic management: Tomes, 2010: 58). In particular, the film zooms in and moralizes the actions of a woman who escapes the household to participate in commercialized leisure activity - in the process infecting with tuberculosis a man, an "innocent" youth, and most damningly, a naval serviceman. The narrative is militarized - the failure of the woman to protect others from the "germ invasion" means that men cannot protect the country's physical borders. Elsewhere, in the British film Surprise Attack, centering on a child's unexpected contraction of smallpox, the doctor (John Le Mesurier) makes an explicit point of pushing the responsibility-and therefore the blame - onto the mother. In one scene, the doctor, while talking to both parents, turns to the mother and directs the question "you've never had her vaccinated, have you?". The mother defensively replies "No, never. I've always been meaning to". This was not a trope confined to the West either, as a similar emphasis on the battle against the microbe as being something domestic and female responsibility was suggested by focusing on two family households in the early Korean documentary Life's Enemy: Cholera, and also in the Japanese film Diseases Spread from 1926, where one household scene suggests a woman's "carelessness" in hygiene and cleanliness tasks first "affects the family, but then the city at large" (see Figure 5.4).

Similar themes were seen during educational documentaries set during the Second World War such as Borne on Two Wings (UK War Office, 1945), where 


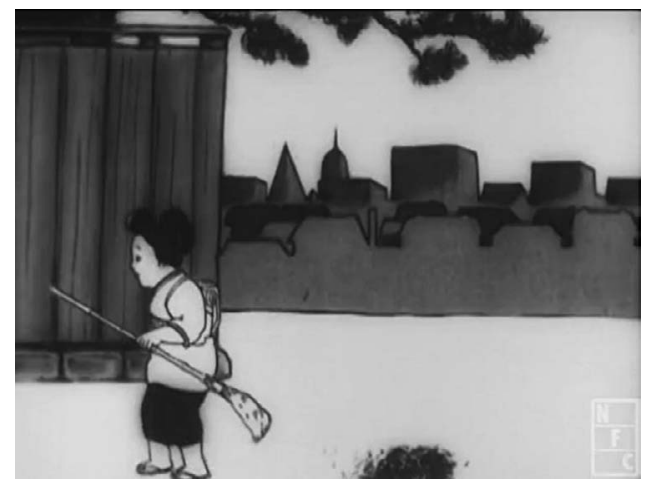

Figure 5.4 The woman's “carelessness” in Diseases Spread (Sanae Yamamoto, 1926)

Source: Captured from original film accessible at https://animation.filmarchives.jp/en/works/playen/5433.

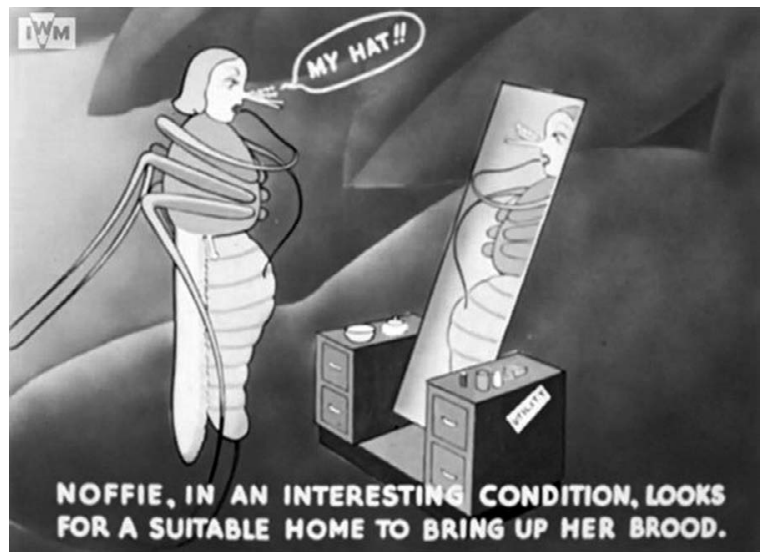

Figure 5.5 "Noffie the Skita" in Borne on Two Wings (UK War Office, 1945)

Source: Captured from original film accessible at www.iwm.org.uk/collections/item/object/1060007319.

the malaria threat is linked to mosquitos symbolized as predatory and promiscuous women wearing makeup - "Noffie the Skita" and her daughter "Anophilina" (Peckham, 2016: 308; Fedunkiw, 2003: 1049-1050; also see Figure 5.5). In one scene, the soldier is found kissing a woman, when he himself gets bitten by Noffie - provoking him to kill the female mosquito. The malarial parasites meanwhile are depicted as a group of corrupted men drinking and partying with several "temptress" women - perhaps portrayed as sex workers. A feature linking many of these documentary films is the focus on personal blame attributed to "deviant" sexual behavior - an aspect predictably present in early public health films on 
sexually transmitted diseases (Pernick, 2007: 24; Parascandola, 2007). Indeed, the sexualized female image in Borne on Two Wings operates on three levelsthe woman "tempting" the military man, the exoticized and "predatory" female mosquito (a species frequently cast in twentieth-century visual culture within the metaphors of predation: Meerwijk, 2020: 130, 139-140), and the female "corrupting" parasites.

These associations were not only found in early educational documentaries but feature films too. Indeed, two of the major female images in the German silent film Die Pest in Florenz was Julia (Marga von Kierska), acting as the "seductress" encouraging Florentine society towards lust and excess, and then the Black Death itself, anthropomorphized and conceptualized as an unkempt female character lurking in the shadows and ready to strike (Julietta Brandt). Furthermore, this moralizing view on female decision-making as a source of societal vulnerability to epidemic outbreaks was not confined to the period before the Second World War. The outbreak of smallpox in The Killer That Stalked New York was linked to a woman (Evelyn Keyes) committing a crime (diamond smuggling), and worse still, infects an innocent young girl, who later dies. Rather than "selfishly" committing suicide at the end of the film, Sheila is forced to "repent" and seek forgivenessturning herself in and providing a list of social contacts. In the British film 80,000 Suspects, the emergence and spread of a localized outbreak of smallpox in the small town of Bath was framed as a distinctly moral issue. Indeed, the pursuit of the final carrier of the disease ends up at the feet of a woman, Ruth Preston (Yolande Donlan), who was having an affair with the central male protagonist in the film, Dr. Steven Monks (Richard Johnson). The condemnation of these actions is magnified when placed against other developments - the fact that Ruth's husband is also a medic, but more importantly, the wife of Dr. Monks contracts and dies from smallpox. Elsewhere, in the US film The Crazies, the highly contagious virus caused by contaminated water supplies - creating people with homicidal tendencies - was actually code named "Trixie", which can be a shortened form of the names Beatrix, Beatrice, or Patricia. Later in this film, an infected man, Artie (Richard Liberty), attempts to rape his daughter, Kathy (Lynn Lowry), and is only prevented by outside intervention. Nevertheless, the viewer is almost encouraged to pity the rapist - who hangs himself - whereas the daughter is "punished" by being shot dead by soldiers the very next day (Williams, 2003: 71-72).

Significantly, however, similar scenes have even been seen in very recent cinema - in particular, during Contagion, already analyzed in Chapter 3. Indeed, the "outbreak narrative" (Wald, 2008) of direction of spread from East to West is set within another narrative of a woman with "loose morals"-Beth Emhoff (Gwyneth Paltrow) - whose decision to have an extra-marital affair ends up spreading the infection further, while "selfishly" already being conscious of her symptoms. The narrative is reinforced by contrasting with the inexplicably immune husband - who selflessly stands up for those who are victimized (against someone trying to steal a woman's rations) and goes out of his way to protect his daughter (McGuire, 2021: 6). Supporting this trope are the initial scenes of the film, set within a Macau casino, reminiscent of the cocktail lounges and nightclubs 
frequented by women of "dubious virtue" in Hollywood film noirs of the 1940s and 1950s (Peckham, 2016: 308). Another twist on this theme is those recent films that instead simply reflect on the guilt of female protagonists for surviving terrible infections, while their other family members all succumb - as seen in the recent Here Alone (Rod Blackhurst, 2016). In the Norwegian Trollsyn, the emphasis is on the fact that the whole medieval village in the valley of Jostedal has perished, except for one survivor: a young eight-year-old girl named Maren (Julia Onsager Steen) with visionary powers (Rees, 2003: 401). ${ }^{2}$

Elsewhere, the same issues appear in the German film Der Medicus (Philipp Stölzl, 2013) - a historical drama based on a 1986 novel of the same name by Noah Gordon-where an English orphan, Rob (Tom Payne), travels to Persia to learn medicine from the famous polymath Ibn Sina [Avicenna] (Ben Kingsley). ${ }^{3}$ One of the female protagonists, a Jewish woman called Rebecca (Emma Rigby), becomes afflicted with plague and is abandoned by her husband who flees the city of Isfahan during the outbreak. She is nursed back to health by Rob, the physician in training, and upon recovery has a sexual relationship with him, in the end falling pregnant. Reported to officials by her returning husband, Rebecca subsequently is sentenced to death by stoning - and must rely on a last-minute reprieve from her impending execution by "white knight" Rob. Throughout the film, Rebecca appears to have little agency beyond being controlled, desired, and saved (Han and Curtis, 2021c).

The female spreader image has furthermore been present within recent zombiepandemic or "end of humanity" crossover movies. In the popular Korean film Train to Busan, the epidemic takes root in the actions of a reckless young woman running onto a train unnoticed, infecting other passengers. And yet, the resolution of the pandemic in the same film, and "the only safe haven outside of the capitalist inhumanity", is centered in the masculine image of the protective father (Kim, 2019: 447). ${ }^{4}$ In the British film, 28 Days Later (Danny Boyle, 2002), the disease origins are found in the actions of a female animal rights activist-her infection presented as a "logical" punishment for her rage. The urgency and necessity of patriarchal oppression can be seen in the male scientist immediately exclaiming: "We have to kill her!" (Adesola Mafe, 2018: 20). The recurring fear of female sexuality also appears within this genre. In Rabid (David Cronenberg, 1977; remade Jen Soska and Sylvia Soska, 2019), a rabies epidemic is set off by a woman (Marilyn Chambers) who develops a form of phallic stinger, creating "hypersexualized embraces" (Livingstone, 1993). Most of her initial victims are male-with two particularly instructive scenes being the infection of a leering customer in a pornographic cinema, and the ending where Rose's corpse is literally tossed away casually into a garbage truck (Weinstock, 2012: 63-64). Cronenberg's preoccupation with particularly female sexual behavior had already been seen two years earlier with the 1975 appearance of Shivers - a film linking the emergence of a terrible parasite taking over human bodies to a sexually transmitted infectiona parasite which in turn pushes the infected into aggressively hyper-sexualized states of being. Indeed, in Shivers, the film ends with an announcement of an "epidemic" of sexual assaults occurring in the city of Montreal. 


\section{From spreaders to sacrifice}

\section{Epidemics and the female burden in cinema}

Throughout cinematic history and even in films produced today, misogynistic and chauvinistic images of women are produced - pushing women into the background, limiting female agency, creating cliched or stereotyped female roles, or instead presenting women with a limited skill set when compared to male protagonists. This is something also seen in films representing women in scientific or public health roles, as mentioned in Chapter 4, often based around marginalization or sexualization of scientific competence (Flicker, 2003), even if these are presented within a broader array of different archetypal images (Steinke, 2005, 1999, 1997; Kasi Jackson, 2011; Hassel, 2008). Films depicting epidemics have, unsurprisingly, not been immune to this trend.

For example, in the popular recent Korean film Flu, an experienced and educated female medical doctor (Soo Ae) is effectively presented as entirely reliant on the efforts of the male protagonist, Ji-goo - an Emergency Response Team member (Jang Hyuk). The doctor is effectively rendered passive, as both herself and her young daughter are time and time again saved by Ji-goo's "heroic" and decisive actions. In the Chinese box-office hit Wolf Warrior 2, centering around an outbreak of "Lamanla" (based loosely on Ebola), a UN medic, Dr. Rachel Prescott Smith (Celina Jade), refuses to evacuate - asserting the desperate need of her specific medical knowledge - and yet is swept off her feet and tossed into a vehicle by the lead male protagonist (Wu Jing), who at the same time exclaims: "Don't make any more trouble for me!". For these two examples, of course, we should recognize context: the female doctor in East Asian contemporary cinema is often presented in such a way as to appease demand for "hyper-masculinity" or valorize masculine protection (Louie, 2012). Nevertheless, related elements exist even in the most recent of mainstream Western cinematic traditions. For example, the epidemiologist, Susan (Eva Green), in Perfect Sense - a film centering on a fictional disease attacking all five human senses - is an educated professional, yet throughout the film is presented as divorced from her working context or laboratory, together with recurring neurotic or unstable behavior patterns.

Perhaps more than in other films, however, women in epidemic-related films are often visually present as active agents - placed right at the center of societal responses to outbreaks (Schweitzer, 2018). Nevertheless, in line with the expectations of the broader medical humanities literature presented earlier, much of this centering of women is often shown by the epidemic providing an exceptional female burden. Frequently, this is visualized down two lines. First, we find those women forced into a cliched role that centers around selflessly caring for others, and upon staying true to their prescribed gender roles during an epidemic, tend to be rewarded with protection and even salvation. Second, we find those women that must go above and beyond the call of duty - in the process endangering their own lives, and sometimes even sacrificing themselves for the perceived "common good".

These images are certainly seen in earlier film history. As mentioned in Chapter 4, in King Vidor's The Citadel, Dr. Andrew Manson's experience 
treating a mining community in south Wales leaves him mentally scarred - and is on a downward spiral by abandoning his medical principles and becoming enticed by wealthy London patients presented as either malingerers or hypochondriacs. Although the death of his friend, Dr. Denny, through the malpractice of an unprofessional surgeon plays a role, it should also be mentioned that Dr. Manson's return towards his "original calling" is mainly stimulated by the attention, devotion, and advice of his wife, Christine (Rosalind Russell). This caregiving role, however, becomes sacrificial in the end: she is involved in a car accident that leaves her infertile. In the original A.J. Cronin novel, this was taken one step further-Christine experiences another accident and dies (shortly after resolving differences with her husband), though in King Vidor's film, this was not included.

These images have also been seen in a variety of filmmaking contexts. In the Egyptian film set in 1947, Al-yawm al-Sadis [The Sixth Day] (Youssef Chahine, 1986), adapted from an earlier novel by Andrée Ghedid, a laundry woman, Saddika (the last acting role of French pop star, Dalida), is depicted in the midst of a cholera outbreak in Cairo mainly doing two things: taking care of her family and resisting the romantic advances of a younger man - despite her own aspirations and dreams which are clearly presented to the audience. A similar story is told in the Italian film Storia di una capinera (Franco Zeffirelli, 1993), the third film adaptation from the original novel by Giovanni Verga (1871) set in the midnineteenth century, where the female protagonist and nun, Maria (Angela Bettis), has to leave the confines of her convent in Catania, Sicily, due to a cholera outbreak (previous film adaptations: Giuseppe Sterni, 1917; Gennaro Righelli, 1943). Through the course of the film, Maria is tempted by life outside the convent - falling in love with a young man in the countryside, Nino (Johnathon Schaech) - but in the end makes the decision to return to a life serving God and the church in the city. It should be noted, however, that in some cases, this recurring theme is presented from a different angle. For example, in the early silent film The Blonde Saint (Svende Gade, 1926), it is the selfless and caregiving efforts of the male protagonist that are foregrounded (Lewis Stone)-looking after a poor village community stricken by cholera (again in Sicily) — which allows him to secure the attention and love of an English woman, Anne Bellamy (Doris Kenyon), and fend off a potential rival (Malcolm Denny).

In many recent films, prescribed gender roles are often hidden behind a veneer of female assertiveness. In Blindness, already analyzed in Chapter 3, the wife of the male ophthalmologist is presented as one of the most central and active characters - becoming a leader of the isolation facility - and yet still this is framed within typical caregiving, guidance, and support tasks. Indeed, through the course of the film, the wife first is presented as being entirely forgiving of her husband's unfaithfulness, continues to tend to the immediate needs of her afflicted partner, and then works to ensure the safety and protection of others in her ward, and eventually even becomes the leading protagonist in the group escape from the institution - guiding followers to safety, despite the threat of violence from other men. This is truly a female burden, since as the only major protagonist of the film 
who retains her vision, she not only bears heavy responsibilities, but also is cursed with the horrors of witnessing the chaos and degradation unfold (Chesney, 2021).

Similarly, in World War Z (Marc Forster, 2013) — depicting a global struggle against a "zombie plague" - the female protagonist, Karin (Mireille Enos), starts the film as the apparent household breadwinner, while her husband Gerry (Brad Pitt) is found in the kitchen making pancakes for the small children. Yet as the pandemic takes hold, the roles are reversed and we see the familiar trope of a man saving women and children (Doyle, 2019). Karin spends most of the film waiting for a phone call from her husband - with one particularly revealing scene being Karin typing GERRY into her satellite phone, while Gerry simply types HOME (Rodriguez, 2013). In other recent films, the future success of society in a postepidemic world rides on the foregrounding of basic female reproductive capacities. In Children of Men (Alfonso Cuarón, 2006), based on a 1992 novel by P.D. James, the story rests on the one lone struggle of a pregnant woman (Clare-Hope Ashitey) who holds the key to human existence after a global flu pandemic leads to widespread infertility (Echeverría, 2015). Similar critiques have been made of the female reproductive role in 28 Days Later (Williams, 2007: 94-95). ${ }^{5}$ The leading female protagonist in the film Ultraviolet (Kurt Wimmer, 2006), Violet (Milla Jovovich) uses her infection with the fictional disease "hemoglophagia" to, in the end, immunize a dying young boy, Six (Cameron Bright)_yet in the process has to sacrifice her own life. In the Korean film 괴물 [Gwoemul/The Host] (Bong Joon-ho, 2006), based around a virus caused by an amphibious creature residing in the Han River, it is a young girl, Park Hyun-seo (Go Ah-sung), who dies attempting to save a young homeless boy.

The woman's role as prominent caregiver is often entrenched in these films centered around epidemic responses - even when we see a transformation in the attitudes, values, and role of the female character across the course of dealing with the disease. For example, in The Painted Veil, already discussed at length in Chapter 3, the film reflects favorably on the disease's capacity to shape the life of the leading female protagonist, Kitty-becoming less defined by the role and knowledge of her husband - but with the proviso that her positive transformation occurs almost entirely through the process of caring for orphaned children in the village. In the end, Kitty's transformation is complete: she turns caregiver for her dying husband — sick in a cholera camp — and then maternalistic protector of her child (rejecting the advances of a man she had an affair with) before the credits roll. Similarly, in Blindness, the transformation of the sex worker in the film is essentially defined by two developments - her romantic association with a kind older man, and her maternalistic protection as the leading caregiver for a young boy in the isolation facility, who was separated from his own mother. In that sense, we can also draw comparisons with the transformation of Dr. Robby Keough (Rene Russo) in Outbreak - beginning the film as cold and dispassionate but by the end is "taught" how to be loving and nurturing (Metz, 2004: 41) - an instructive lesson given by a man, Dr. Sam Daniels.

These redemptive narratives have not emerged suddenly out of nowhere but have precedents in the earliest phases of cinematic history. In a silent film from 
1919, A Man's Country — positively regarded when released (Anon., 1919a: 46), and once said to be "lost" for many decades - a woman, Kate Carewe (Alma Rubens) is presented as a wild and immoral influence in the mid-nineteenthcentury gold-mining community: shooting up a religious service, playing card games with unsavory characters, and explicitly described as a "scarlet woman". 6 In this film, just as in The Painted Veil, an epidemic disease serves as the vehicle behind which Kate "sees the error of her ways"-upon confinement and conversation with a male preacher (Alan Roscoe)_-and during the refuge becomes the caregiver and protection to three unsupervised children.

Twenty years later, in 1939, we see the production of a similar tale of female redemption in The Rains Came. English aristocrat Lady Edwina Esketh (Myrna Loy) arrives in a fictional town of Ranchipur in India, and despite being married to Lord Esketh (Nigel Bruce), is initially portrayed as wild and hedonisticlooking to seduce other men. An earthquake, leading to a flood, and then a cholera outbreak, becomes the context behind her redemption-taking on a selfless role as caregiver to the local sick community. In the 1939 version, Lady Esketh drinks from an infected glass and dies, but in the remake in 1955 under the name The Rains of Ranchipur (Jean Negulesco, 1955), she (Lana Turner) instead voluntarily decides to leave her true love Dr. Safti (Richard Burton) and stay in a loveless marriage with her husband (Michael Rennie) as a personal sacrifice so that he can focus on the suffering cholera-afflicted community that depended on him. Produced in the context of British decolonization, this has been framed by some scholars as an intended "voluntary gift" which is part of a prevailing ideology of "maternal imperialism" (Chowdhry, 2000: 259). This resolve for elite Western women - in colonial or quasi-colonial contexts - to become helpers and caregivers in isolated environments hit by cholera is a recurring theme-The Painted Veil, The Rains Came, but also in films such as The Elephant Walk (William Dieterle, 1954), set on a Ceylon tea plantation, with the female role played by Elizabeth Taylor.

As already mentioned in Chapters 3 and 4, the film Contagion shows numerous images of female epidemiologists and epidemic management officials responding during an outbreak-risking their own lives for the perceived greater good. On an even more extreme, perhaps disturbing, level, many films about epidemics have also used the threat of sexualized violence as a way of creating this same narrative of a female "sacrifice" for the broader collective good. This is found going back in cinematic history (see, for example, Michèle Morgan, as Nellie, fending off the violent attentions of "Don Rodrigo" in the highly regarded Les Orgueilleux), and one of the very classic demonstrations is the final film directed by John Ford in his career, 7 Women (1966). In this film set in rural China in 1935 - and indeed based on a short story from 1935 by Norah Lofts called Chinese Finale - the narrative is set around a group of white Western women working at a remote Catholic missionary. A cholera outbreak is the context through which the leading female protagonist Dr. Cartwright (Anne Bancroft) ends up at the missionary, although the problems are intensified by the presence and threat of a Mongolian warlord, Tunga Khan (Mike Mazuki), who has already ransacked 
a nearby British missionary. Later in the film, Dr. Cartwright asks Tunga Khan for access to her medical bag so she can treat a pregnant woman but is only able to do so after agreeing to be his concubine. Agatha Andrews (Margaret Leighton) as the head of the mission refers to Dr. Cartwright as the "whore of Babylon" and a "scarlet woman" (Meuel, 2014: 147), yet this sacrifice is actually recognized by the other women - perhaps one of the few counterexamples to the "unrecognized medic" described in Chapter 4. As part of her sacrifice, Dr. Cartwright later negotiates better conditions with the warlord and then the release of the other women. Although Dr. Cartwright at the end poisons Tunga Khan, her martyrdom is complete when she also voluntarily drinks a second poison herself-the ordeal that she has endured proving too much to bear.

This is also a narrative employed in more recent films, such as the grisly rape scenes depicted in Blindness, already described in Chapter 3, where a collective of blind women from the ward take on personal responsibilities - sacrificing themselves by first agreeing to the demands of the men of ward three, to secure food and resources for themselves and the other residents of the ward. In Anazapta, based on a medieval plague apparently modeled on the Black Death, the leading female protagonist, Lady Matilda (Lena Headey), spends much of the film evading the sexual advances of dubious men. As a noblewoman at the head of a peasant village, she tries to hold a pious mass to ease the worries of the villagers fearful of the plague - but must submit to a bishop's sexual advances for it to happen.

It should, however, be noted that in some films, the female burden during epidemics is not always linked to a desire to sacrifice oneself for the collective good, but simply as a defense mechanism in the context of vulnerabilities born out of inequalities seen not only down the lines of gender, but also interacting with socioeconomic status and race as a form of intersectionality. In the recent film, Mudbound (Dees Rees, 2017), set in rural Mississippi around the time of the Second World War, a black woman, Florence (Mary G. Blige), from a poor sharecropping family is effectively coerced into acting as a caregiver for the young children of a white landowning family that have contracted the highly contagious whooping cough. $^{7}$ As Florence goes on to explain to the audience, she does not agree to do this out of a form of "duty" (she has medical experience as a midwife), but simply to refuse would have put her own family in danger in this highly inequitable relationship. This was not even the end of her burden - the death of a child under her care would similarly have put her in a vulnerable situation given the underlying power dynamics and social context.

\section{Mutual reinforcement of the female spreader and burdened woman images}

It should be noted that the two recurring cinematic representations of women - as both blamed for poor moral choices and revered for caregiving and sacrificial qualities - have, at times, been simultaneously present within certain films, as mutually reinforcing frameworks. For example, in another early malaria film, You Too Can Get Malaria (Sydney Box, 1944), we see-like in the aforementioned 
Borne on Two Wings - the emphasis on the female mosquito and allusions to promiscuity, and yet this is placed against earlier examples of so-called "female meddling". In one scene, the girlfriend urges Private Bill Smith to put his coat on to keep warm, and in another it is a waitress who warns him that his cocoa is "piping hot" - provoking his angry rebuke: "I'm a soldier, not a hothouse rose!" (Fedunkiw, 2003: 1049).

This mutual reinforcement is clearly seen in the revered 1938 film Jezebel, based on a 1933 play by Owen Davis, and set within the backdrop of a yellow fever outbreak in the middle of nineteenth-century New Orleans - in fact, modeled on a real epidemic that took place in 1853 (Duffy, 1966). On the one hand, the whole reason for the outbreak in the city - and the chaos that ensues - is linked, at least implicitly, to the morally suspect choices of the female protagonist, Julie Marsden (Bette Davis), not in line with "Southern culture". Julie wears an inappropriate red dress to the ball (after being warned not to), publicly slaps her fiancé, Pres (Henry Fonda), and schemes to get this man back (after he marries another more "appropriately behaved woman"), leading inadvertently to the death of another longterm admirer (Tuhkunen, 2016). Significantly, the red dress appears dark black in the black and white film (Figure 5.6), creating a further coded message that white southerners expected white "ladies" to conform to chaste values, while notions of sexual promiscuity are pushed onto black women (Bibler, 2008: 17). The trailer for the film summarizes this best with its claim: "the story of a woman who was loved, when she should have been whipped!". Yet on the other hand, as the outbreak of yellow fever grips the town - and Pres is wheeled away to a quarantined camp on Lazaret Island-Julie turns sacrificial caregiver, despite Pres announcing love for his wife, Amy, and thus presented as an act of final redemption.

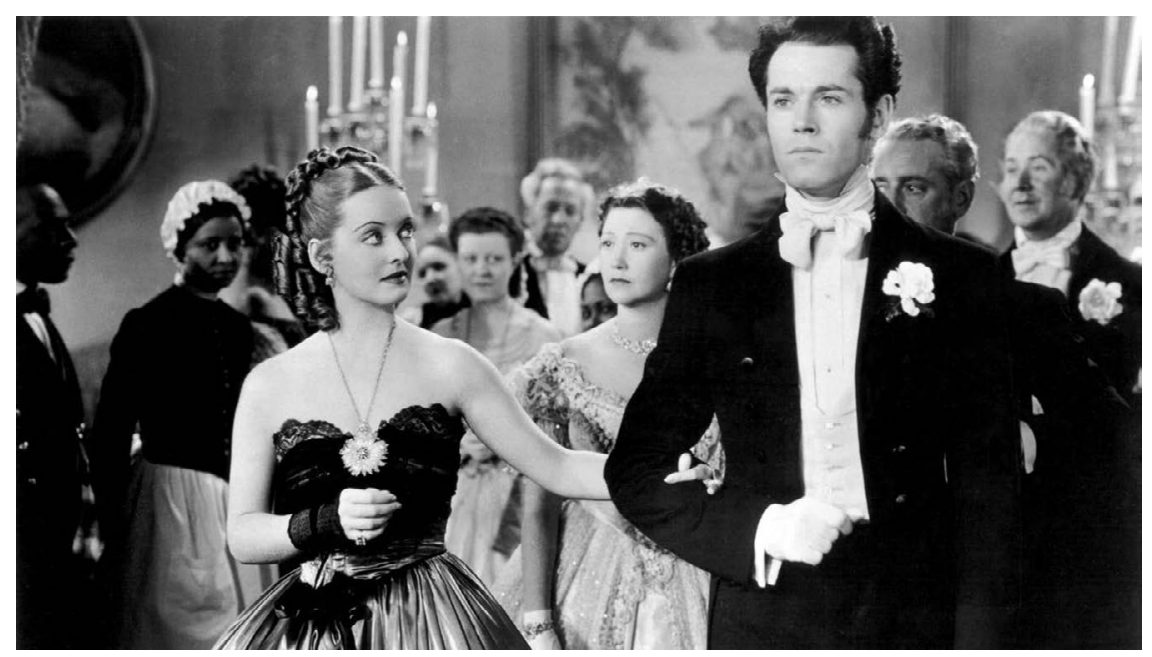

Figure 5.6 "The red dress" in Jezebel (William Wyler, 1938)

Source: Captured from personal copy. 
The simultaneous existence of both spreader and sacrificial images were also seen in the American post-war film, Saadia (Albert Lewin, 1953), set and filmed entirely in Morocco. Given that Saadia, the female protagonist and Berber (Rita Gam), has spent her life under the spell of a vengeful sorceress, Fatima (Wanda Rotha), Saadia is convinced that she is to blame for the emergence of bubonic plague in a local town (the spreader image), and accordingly risks her own life to find the necessary serum in the mountains, being held to ransom by bandits (the sacrificial image).

Elsewhere, in the British film Vampire Circus (Robert Young, 1972), a Hammer horror production, set in a Serbian village in the nineteenth century, one woman, Anna (Domini Blythe), later known as the Gypsy Woman (Adrienne Corri), does the bidding of a vampire, Count Mitterhaus (Robert Tayman), which directly leads to the spread of a plague curse. For this she is punished by a group of angry villagers, lining up and visibly taking pleasure in whipping her for her perceived sins. By the end of the film, however, the same woman must recognize and atone for her supposed immorality, by remorsefully sacrificing herself to save another girl, Dora (Lynne Frederick). The links between vampires, plague curses, and female sacrifice remained persistent through many horror films of the $1970 \mathrm{~s}-$ not least the death of Lucy Harker (Isabelle Adjani) in Nosferatu: Phantom der Nacht, which of course addressed similar themes to the original adaptation produced back in the silent film era, Nosferatu, eine Symphonie des Grauens-but also in the early death of Lucy Westenra (Fiona Lewis/Sadie Frost) in Bram Stoker's Dracula (Dan Curtis, 1974; readapted in Francis Ford Coppola, 1992), who openly courts the affections of three men (Castel et al., 2013: 365). Especially in the more recent Coppola version, the film moves between two extremes: a suppressed and passive female that once bitten displays "excessive" sexuality (Cordell, 2013: 13, 16-17). ${ }^{8}$ In The Satanic Rites of Dracula (Alan Gibson, 1973), based on a vampire story interweaved with elements of bioterrorism and the deliberate cultivation of a virulent Yersinia pestis strain, we see other female characters subscribing to "spreader" or "sacrificial" tendencies. The secret service secretary, Jane (Valerie Van Oost), is kidnapped by Dracula, chained to a wall of a cellar, and eventually killed with a stake, while Chin Yang (Barbara Yu Ling) is also exposed as a vampire and killed with a mallet to the heart.

In more recent times, we can turn once again to the sex worker in Blindness or the vain socialite Kitty in The Painted Veil as prominent examples of moral condemnation giving way across the course of the epidemic itself to a role more in line with expectations of care and protection. And of course, the links between the two frameworks can move in the opposite direction too - as recently observed for popular zombie-infection television shows such as The Walking Dead (Robert Kirkman, Tony Moore, and Charlie Adlard, 2010-2020). Indeed, it has been noted that many of the female characters "keep house" during the first two seasons - cleaning, doing laundry, and cooking - and are ultimately punished as soon as they start to defy prescribed gender roles (Schweitzer, 2018: 186). This defiance links up with a recent view on zombie films that interprets these sorts of infection apocalypses as a context behind female resistance to existing power structures (Hubner et al., 2015: 8). ${ }^{9}$ 


\section{Conclusion}

In this chapter, we have shown numerous examples where women are placed at the center of the social responses to the outbreak within cinematic history. However, recurring representations of female characters often tend to fall into two categories: the "burdened woman" image, sacrificing her own well-being for the "collective good", and the "female carrier" image, where women not fitting within the prescribed gender roles emphasizing domesticity, caregiving, or maternalism are viewed as the infection itself, and hence carry a threat to the "collective good" - code for men or male-dominated institutions. Although inevitably nuanced and adapted over time, aspects of these images can be traceable from the earliest documentary and feature films of the 1920s and 1930s to more modern pictures after the turn of the millennium. It remains to be seen whether the cinematic images of women during epidemics discussed in this chapter are mere reflections of these gendered roles already seen within society, or these cinematic images actually help to reinforce and entrench these gendered expectations of behavior during epidemic disease outbreaks. Given the capacity for films to become effective mediums for delivering messages through emotive narrative and relatable characters (as discussed in Chapter 1) - especially in public health contexts - the second option is at least a distinct possibility.

On occasion, these two visual frameworks for female behavior during epidemics have been even depicted together in the same film, and of course, within these broad categories there are further nuances. Although consistently perpetuating the "burdened woman" image in Blindness, for example, the film also emphasizes less discussed related aspects such as female solidarity during epidemics, as discussed in Chapter 3. In the post-Second World War film Sister Kenny (Dudley Nichols and Jack Gage, 1946), about a nurse (Rosalind Russell) treating those suffering from an outbreak of polio in the bush areas of Queensland, Australia, Elizabeth Kenny is presented in typical sacrificial and caregiving terms, but also with nuances - in particular, her propensity to challenge power structures within public health institutions and orthodox medical thinking of the patriarchal establishment. This was seen in the case of the already mentioned female scientist, Dr. Ruth Leavitt, in The Andromeda Strain. It should be noted also that that male sexual behavior has been moralized within films depicting epidemics-such as the trial of the seventeenth-century French Catholic priest, Urbain Grandier (Oliver Reed), in the controversial The Devils - but the difference with the "female spreader" image is that no causal links were drawn or inferred from the priest's behavior and the emergence of outbreaks of plague.

This discussion of female burden and moral condemnation of female behavior, moreover, should also not be taken to mean that films have not reflected on the hardships experienced by men during epidemic disease outbreaks. In some cases, this male image was wholly different to that of female- see, for example, the symbol of the male epidemiologist as "culture hero", preserving humanity through professionalism, self-sacrifice, compassion, and empathy (Lynteris, 2016a), as described in Chapter 4. Despite being visualized displaying different 
elements of self-sacrifice, women have not shared in that cinematic image of societal responses to epidemics. Films have also used female images to say something more substantial about men. The Mexican film El año de la peste uses female images - such as the unsuspecting and innocent women from an abandoned asylum - to focus on the indiscriminate and excessive use of arbitrary violence by (male) authorities (Rocco, 2014: 79).

Furthermore, in some cases, films have used subtle and multi-faceted gender images to show male and female shared experiences. For example, Agnes (Jennifer Jason Leigh) in Paul Verhoeven's Flesh+Blood (1985), does not entirely conform to a spreader or sacrificial figure, but instead is instrumentalized by the director as one character among many — both male and female - to highlight moral ambiguity, self-interest, and opportunism (Han and Curtis, 2021c). Elsewhere, in the Taiwanese film, The Hole, the epidemic disease spread by cockroaches, "Taiwan Fever", is instrumentalized to show what men and women sometimes share as poor and marginalized individuals dealing with hardship-inducing crises. In particular, both central characters - the "man upstairs" and the "woman downstairs" - suffer with the feeling of isolation and loneliness at the periphery of their urban environment, and the struggle against the leaking water between the two apartments is an allegory for common humanity (Chang, 2008: 26). Indeed, Chang has gone further to argue that the emphasis of the film on the shared water supplies help establish a vision of "sameness and collectivity" (2008: 39). ${ }^{10}$

It is on this note that in Chapter 6 we consider the impact of socio-economic status on societal responses to epidemics that are visualized through film-with a specific focus on the differences between urban and rural conceptions of poverty. As with the case of the cinematic representation of medics and women during epidemics, described in Chapters 4 and 5, the lines drawn between categories such as "hero" and "villain", "revered" and "accused", "vulnerable" and "protected", become problematized when looking at the varying and, at times, conflicted depictions of the wealthy and the poor.

\section{Notes}

1 Witch burning has taken a prominent role in the history of Scandinavian cinema, but often with a sympathetic take on the female witch's experiences (Badley, 2013).

2 The same "second sight" or visionary powers was already used some years previous in another Australian/New Zealand film set during the Black Death in the fourteenth century, although this time in Cumbria, England-The Navigator: A Medieval Odyssey (Vincent Ward, 1988).

3 While the epidemic represented in Der Medicus occurs after the end of the first plague pandemic and before the beginning of the second plague pandemic using traditional chronologies, new historical, bio-archaeological, and genetic research is starting to revise these entrenched views. Thus, a plague in the eleventh century, for example, may not prove to be quite so unrealistic (Keller et al., 2019; Green, 2020a).

4 Thanks to Daniëlle de Kurver for the reference.

5 Thanks to Daniëlle de Kurver for the reference.

6 An incomplete fragment of the film was found in Danish Film Institute in Copenhagen.

7 Indeed, Mississippi had some of the highest case rates per population in the United States in the 1930s and 1940s (Dauer, 1943: 674). Sharecropping (the tenurial arrangement of capital provided by a landlord, labor provided by a farming family, and 
output divided between landlord and farmer) was widespread in the southern areas of nineteenth- and early twentieth-century America, as former slaves and their descendants often did not have finances to buy equipment and animals.

8 Thanks to Daniëlle de Kurver for the reference.

9 Thanks to Daniëlle de Kurver for the reference.

10 Although others have emphasized the spatial inequalities in the residential situation, allowing the male gaze into the female apartment (Ganjavie, 2012: 40-41).

\section{References}

Adesola Mafe, Diana. Where No Black Woman Has Gone Before: Subversive Portrayals in Speculative Film and TV. Austin, TX: University of Texas Press, 2018.

Anon. "Robertson-Cole Well Satisfied with Receipts During Summer." Exhibitors Herald 9, 8 (1919a): 46.

Arnold, David. Colonizing the Body: State Medicine and Epidemic Disease in NineteenthCentury India. Berkeley, CA: University of California Press, 1993.

Badley, Linda. "Antichrist, Misogyny and Witch Burning: The Nordic Cultural Contexts." Journal of Scandinavian Cinema 3, 1 (2013): 15-33.

Bibler, Michael P. "Always the Tragic Jezebel: New Orleans, Katrina, and the Layered Discourse of a Doomed Southern City." Southern Cultures 14, 2 (2008): 6-27.

Black, Winston. The Middle Ages: Facts and Fictions. Santa Barbara, CA: ABC-CLIO, 2019.

Castel, Olivier, A. Bourry, S. Thévenot and C. Burucoa. "Bactéries et vampirisme au cinéma." Médecine et Maladies Infectieuses 43, 9 (2013): 363-367.

Chang, Kai-man. "Gender Hierarchy and Environmental Crisis in Tsai Ming-liang's 'The Hole'." Film Criticism 33, 1 (2008): 25-44.

Chesney, Duncan McColl. "Re-Reading Saramago on Community-Blindness." Critique: Studies in Contemporary Fiction 62, 2 (2021): 211-223.

Chowdhry, Prem. Colonial India and the Making of Empire Cinema: Image, Ideology and Identity. Manchester: Manchester University Press, 2000.

Cohn, Samuel Kline. Epidemics: Hate and Compassion from the Plague of Athens to AIDS. Oxford: Oxford University Press, 2018.

Cordell, Sigrid Anderson. "Sex, Terror, and Bram Stoker's Dracula: Coppola's Reinvention of Film History." Victorian Studies 6, 1 (2013): 1-21.

Criado Perez, Caroline. Invisible Women: Exposing Data Bias in a World Designed for Men. New York: Random House, 2019.

Curtis, Daniel R. "The Female Experience of Epidemics in the Early Modern Low Countries." Dutch Crossing: Journal of Low Countries Studies 45, 1 (2021): 3-20.

Dauer, C.C. "Reported Whooping Cough Morbidity and Mortality in the United States." Public Heath Reports (1896-1970) 58, 17 (1943): 661-676.

Davies, Sara E. and Belinda Bennett. "A Gendered Human Rights Analysis of Ebola and Zika: Locating Gender in Global Health Emergencies.” International Affairs 92, 5 (2016): 1041-1060.

Doyle, Kelly. "Masculinity, Human Hierarchy and American Exceptionalism in World War Z." In: Robert Shail, Samantha Holland and Steven Gerrard (eds.), Gender and Contemporary Horror in Comics, Games and Transmedia, pp. 121-131. Bingley: Emerald Publishing Limited, 2019.

Duffy, John. Sword of Pestilence: The New Orleans Yellow Fever Epidemic of 1853. Baton Rouge, LA: Louisiana State University Press, 1966.

Echeverría, Julia. "Liquid Cinematography and the Representation of Viral Threats in Alfonso Cuarón's Children of Men.” Atlantis 37, 2 (2015): 137-153. 
Echeverría, Julia. "The Women Who Killed Too Many: Contagion (Steven Soderbergh, 2011) and Female Virality." In: David Roche and Cristelle Maury (eds.), Women Who Kill: Gender and Sexuality in Film and Series of the Post-Feminist Era, pp. 209-225. London: Bloomsbury, 2020.

Fedunkiw, Marianne. "Malaria Films: Motion Pictures as a Public Health Tool." American Journal of Public Health 93, 7 (2003): 1046-1057.

Fisher, Jane Elizabeth. Envisioning Disease, Gender and War: Women's Narratives of the 1918 Influenza Pandemic. New York: Palgrave Macmillan, 2012.

Flicker, Eva. "Between Brains and Breasts-Women Scientists in Fiction Film: On the Marginalization and Sexualization of Scientific Competence." Public Understanding of Science 12, 4 (2003): 307-318.

Ganjavie, Amir. "Representation of Space/Place in Tsai Ming Liang's The Hole." CrossCultural Communication 8, 3 (2012): 37-45.

Godderis, Rebecca and Kate Rossiter. "'If You Have a Soul, You Will Volunteer at Once': Gendered Expectations of Duty to Care During Pandemics." Sociology of Health and Illness 35, 2 (2013): 304-308.

Green, Monica H. “The Four Black Deaths.” American Historical Review 125, 5 (2020a): 1601-1631.

Han, Qijun. The Cinematic Representation of the Chinese American Family. Cambridge: Cambridge Scholars Publishing, 2016.

Han, Qijun and Daniel R. Curtis. "Cinematic Representation of Early Modern Women and Epidemics.” Early Modern Women: An Interdisciplinary Journal 16, 1 (2021c): 123-134.

Harman, Sophie. "Ebola, Gender and Conspicuously Invisible Women in Global Health Governance." Third World Quarterly 37, 3 (2016): 524-541.

Harman, Sophie, Julie Patarin-Jossec, Susan Hansen and John Grady. "On Film as a Method, Gender and Health Politics: Conversation with Sophie Harman.” Visual Studies 36, 1 (2021): 3-10.

Hassel, Holly J. “The 'Babe Scientist' Phenomenon: The Illusion of Inclusion in 1990s American Action Films.” In: Suzanne Ferriss and Mallory Young (eds.), Chick Flicks: Contemporary Women at the Movies, pp. 190-203. New York: Routledge, 2008.

Hubner, Laura, Marcus Leaning and Paul Manning. "Introduction." In: Laura Hubner, Marcus Leaning and Paul Manning (eds.), The Zombie Renaissance in Popular Culture, pp. 3-14. New York: Palgrave Macmillan, 2015.

Kasi Jackson, J. "Doomsday Ecology and Empathy for Nature: Women Scientists in 'B' Horror Movies." Science Communication 33, 4 (2011): 533-555.

Keller, Marcel, Maria A. Spyrou et al. "Ancient Yersinia Pestis Genomes from across Western Europe Reveal Early Diversification during the First Pandemic (541-750)." Proceedings of the National Academy of Sciences 116, 25 (2019): 12363-12372.

Kim, Jaecheol. "Biocalyptic Imaginations in Japanese and Korean Films: Undead NationStates in I Am a Hero and Train to Busan." Inter-Asia Cultural Studies 20, 3 (2019): 437-451.

Larsen, Mads. "Belief System Disintegration: Evolutionary Insights from Bergman's Det Sjunde Inseglet." World Futures: The Journal of New Paradigm Research 75, 8 (2019): 632-652.

Lewis, Helen. "Coronavirus is a Disaster for Feminism: Pandemics Affect Men and Women Differently." The Atlantic, March 19, 2020a, www.theatlantic.com/international/ archive/2020/03/feminism-womens-rights-coronavirus-covid19/608302/.

Livingstone, Ira. "The Traffic in Leeches: David Cronenberg's 'Rabid' and the Semiotics of Parasitism.” American Imago 50, 4 (1993): 515-533. 
Louie, Kam. "Popular Culture and Masculinity Ideals in East Asia, with Special Reference to China." Journal of Asian Studies 71, 4 (2012): 929-943.

Lynteris, Christos. "The Epidemiologist as Culture Hero: Visualizing Humanity in the Age of the Next Pandemic." Visual Anthropology 29, 1 (2016a): 36-53.

McGuire, Kelly. "COVID-19, Contagion, and Vaccine Optimism." Journal of Medical Humanities 42, 1 (2021): 51-62.

Meerwijk, Maurits Bastiaan. "Tiger Mosquitos from Ross to Gates.” In: Christo Lynteris (ed.), Framing Animals as Epidemic Villains: Histories of Non-Human Disease Vectors, pp. 147-176. Cham: Springer, 2020.

Metz, Walter. Engaging Film Criticism: Film History and Contemporary American Cinema. New York: Peter Lang, 2004.

Meuel, David. Women in the Films of John Ford. Jefferson, NC: McFarland \& Company, 2014.

Munkhoff, Richelle. "Searchers of the Dead: Authority, Marginality, and the Interpretation of Plague in England, 1574-1665." Gender and History 11, 1 (1999): 1-29.

Naphy, William. Plagues, Poisons and Potions: Plague-Spreading Conspiracies in the Western Alps, c. 1530-1640. Manchester: Manchester University Press, 2002.

Neumayer, Eric and Thomas Plümper. "The Gendered Nature of Natural Disasters: The Impact of Catastrophic Events on the Gender Gap in Life Expectancy, 1981-2002." Annals of the Association of American Geographers 97, 3 (2007): 551-566.

Noordegraaf, Leo and Gerrit Valk. De Gave Gods: De pest in Holland vanaf de late Middeleeuwen. Bergen: Octavo, 1988.

Ostherr, Kirstin. "Contagion and the Boundaries of the Visible: The Cinema of World Health." Camera Obscura: Feminism, Culture, and Media Studies 17, 2 (2002): 1-40.

Ostherr, Kirstin. Cinematic Prophylaxis: Globalization and Contagion in the Discourse of World Health. Durham, NC: Duke University Press, 2005.

Parascandola, John. "Syphilis at the Cinema: Medicine and Morals in VD Films of the U.S. Public Health Service in World War II.” In: Leslie J. Reagan, Nancy Tomes and Paula A. Treichler (eds.), Medicine's Moving Pictures: Medicine, Health, and Bodies in American Film and Television, pp. 71-92. Rochester, NY: University of Rochester Press, 2007.

Peckham, Robert. Epidemics in Modern Asia. Cambridge: Cambridge University Press, 2016.

Pernick, Martin S. "More Than Illustrations: Early Twentieth-Century Health Films as Contributors to the Histories of Medicine and of Motion Pictures." In: Leslie J. Reagan, Nancy Tomes and Paula A. Treichler (eds.), Medicine's Moving Pictures: Medicine, Health, and Bodies in American Film and Television, pp. 19-35. Rochester, NY: University of Rochester Press, 2007.

Qian, Kun. Imperial-Time-Order: Literature, Intellectual History, and China's Road to Empire. Boston: Brill, 2015.

Rees, Ellen. "Dreaming of the Medieval in 'Kristin Lavransdatter' and 'Trollsyn'." Scandinavian Studies 75, 3 (2003): 399-416.

Rees-Roberts, Nick. "Queer Sexuality, AIDS and Loss.” In: Nick Rees-Roberts (ed.), French Queer Cinema, pp. 89-128. Edinburgh: Edinburgh University Press, 2008.

Ribeiro, Barbara, Sarah Hartley, Brigitte Nerlich and Rusi Jaspal. "Media Coverage of the Zika Crisis in Brazil: The Construction of a 'War' Frame that Masked Social and Gender Inequalities.” Social Science and Medicine 200 (2018): 137-144.

Rocco, Alessandro. Gabriel García Márquez and the Cinema: Life and Works. Woodbridge: Tamesis, 2014.

Rodriguez, A. "The Strong Yet Traditional Women of 'World War Z'.” Bitch Flicks, July 3, 2013, www.btchflcks.com/2013/07/the-strong-yet-traditional-women-of-world-war-z. html\#.XtDekTozZPY. 
Schweitzer, Dahlia. Going Viral: Zombies, Viruses, and the End of the World. New Brunswick, NJ: Rutgers University Press, 2018.

Singer, Linda. Erotic Welfare: Sexual Theory and Politics in the Age of Epidemic. London: Routledge, 1993.

Smith, Julia. "Overcoming the 'Tyranny of the Urgent': Integrating Gender into Disease Outbreak Preparedness and Response." Gender and Development 27, 2 (2019): 355-369.

Sochas, Laura, Andrew Amos Channon and Sara Nam. "Counting Indirect Crisis-Related Deaths in the Context of a Low-Resilience Health System: The Case of Maternal and Neonatal Health during the Ebola Epidemic in Sierra Leone." Health Policy Plan 32, 3 (2017): 32-39.

Steinke, Jocelyn. "A Portrait of a Woman as a Scientist: Breaking Down Barriers Created by Gender-Role Stereotypes.” Public Understanding of Science 6, 4 (1997): 409-428.

Steinke, Jocelyn. "Women Scientist Role Models on Screen: A Case Study of Contact." Science Communication 21, 1 (1999): 111-136.

Steinke, Jocelyn. "Cultural Representations of Gender and Science: Portrayals of Female Scientists and Engineers in Popular Films." Science Communication 27, 1 (2005): 27-63.

Tomes, Nancy. “'Destroyer and Teacher': Managing the Masses during the 1918-1919 Influenza Pandemic." Public Health Reports 125, 3 (2010): 48-62.

Tuhkunen, Taïna. "New Orleans as the City of Misfit Women in Jezebel (William Wyler, 1938) and The Flame of New Orleans (René Clair, 1941)." Revue électronique d'études sur le monde anglophone 14, 1 (2016), https://journals.openedition.org/erea/5343?lang=fr.

Wald, Priscilla. Contagious: Cultures, Carriers, and the Outbreak Narrative. Durham, NC: Duke University Press, 2008.

Walton, Sarah-Jane. "Motherhood, Morality and Materiality: How Material Changes to Wartime Cape Town Affected Discourses Around Women, Racial Health and the City, 1914-1919." Urban History 48, 1 (2021): 54-70.

Weinstock, Jeffrey. The Vampire Film: Undead Cinema. New York: Columbia University Press, 2012.

Wenham, Clare, João Nunes, Gustavo Correa Matta, Carolina de Oliveira Nogueira, Polyana Aparecida Valente and Denise Nacif Pimenta. "Gender Mainstreaming as a Pathway for Sustainable Arbovirus Control in Latin America." PLoS Neglected Tropical Diseases 14, 2 (2020b): e0007954.

Wenham, Clare, Julia Smith, Sara E. Davies, Huiyun Feng, Karen A. Grépin, Sophie Harman, Asha Herten-Crabb and Rosemary Morgan. "Women Are Most Affected by Pandemics: Lessons from Past Outbreaks.” Nature 583 (2020c): 194-198.

Wenham, Clare, Julia Smith and Rosemary Morgan. "COVID-19: The Gendered Impacts of the Outbreak." The Lancet 395, 10277 (2020a): 846-848.

Williams, G. Christopher. "Birthing an Undead Family: Reification of the Mother's Role in the Gothic Landscape of 28 Days Later." Gothic Studies 9, 2 (2007): 33-44.

Williams, Tony. The Cinema of George A. Romero: Knight of the Living Dead. London: Wallflower Press, 2003.

Zimmerman, Susan. "Leprosy in the Medieval Imaginary." Journal of Medieval and Early Modern Studies 38, 3 (2008): 559-587. 


\section{Between urban depravity and rural backwardness}

\section{Cinematic depiction of poverty during epidemics}

Most epidemic diseases disproportionately burden, afflict, and take the lives of the poor - for a multiplicity of factors related to inequitable exposure to points of contagion through work and residential situations, and inequitable access to food, resources, welfare, protection, and knowledge. Governments attempting to "manage" epidemics by invoking public health regulations and quarantines and isolation methods have long been concerned by the perceived threat of the poornot only in their spatial concentration within environments of "literal filth" but also through negative views on the poor's habits and morality (Pelling, 2001: 21). Accordingly, much of the othering seen during epidemics down the lines of race, ethnicity, or migratory status also inevitably incorporates a socio-economic component. Similarly, with the "female spreader" image discussed in Chapter 5, wealth, power, and position — or a lack of it - forms an important part of the trope. For example, the identity of "Typhoid Mary" was built not only upon her status as a single woman, but also as a poor Irish migrant (often working in very wealthy households). Poverty, furthermore, is an essential component of Wald's "outbreak narrative" (2008) - the fear of a spread of disease moving from marginalized groups and economically less prosperous areas to more modernized and "developed" societies. Indeed, in the 1950 classic Panic in the Streets, it is clear that the first victim is not only an immigrant, but also concealed by an "underworld" of other immigrants and vulnerable laborers - smuggled in via a ship (The Nile Queen) with a predominantly black and Asian crew (Zaniello, 2020: 66). Here we see many of the components linked together-race, ethnicity, migratory status, and socio-economic position. The same is seen in contemporary non-Western cinema. In the Korean Flu, the first victim is a poor migrant, Monssai (Lester Avan Andrada) from the Philippines - shoved into a shipping container and transported like a "product" by traffickers.

However, just as there are complexities and contradictions in the images of public health officials (Chapter 4) and women (Chapter 5) during epidemics, the poor are similarly not represented as one homogenous mass or under one universal framework. Indeed, history has shown that the poor have not always been the logical persecuted during times of epidemic disease outbreaks, but instead, on occasion, served as the "antagonists" - as with the nineteenth- and early twentieth-century cholera outbreaks, where the poor actively attacked and

DOI: $10.4324 / 9781003261667-6$ 
victimized perceived elite groups such as medics and government officials (Cohn, 2018). Accordingly, the poor in films such as 28 Days Later and 28 Weeks Later (Juan Carlos Fresnadillo, 2007) are presented only as partial victims - they are also conceived of as "mindless perpetrators" (Zaniello, 2020: 67). In the 1930s film, Jezebel, the poor are again only portrayed as partial victims. On the one hand they lack the means to flee the city of New Orleans, with the police found protecting the property of the more affluent neighborhoods of the "white aristocracy" - and yet on the other hand the narrative also establishes a discourse of a perpetually doomed southern city, with the epidemic an inevitable product of backwardness, decadence, corruption, conservativism, and poverty (Bibler, 2008). And when we look further into the past, we understand that the connection between diseases such as plague and immorality included socio-economic dimensions, but not always inevitably a castigation of the poor. In Simon Schama's The Embarrassment of Riches, for example, plague in the "Golden Age" of the seventeenth-century Dutch Republic, alongside other afflictions and calamities, was a providential punishment for greed, avarice, and ostentation (1988). Considered in the same light, as we demonstrate in this chapter, epidemics have also been instrumentalized by film directors as a way of critiquing some of the worst effects of (global) capitalism by zooming in on excess and over-consumption.

In Chapter 6, we show that the cinematic representation of the poor during epidemics holds a similarly conflicted and complicated position. First, from the earliest films, there is a blurred line between sympathetic and patronizing images, and a blurred line between seeing the poor as the logical victims of epidemics, and a moralizing view on the actions and decisions of the poor as the logical cause. Often, it is difficult to separate the two. Second, space, landscape, and environment have remained important features of the divided cinematic view of the poor during epidemics. One aspect of this is a contrast between different rural environments themselves, although both spinning around notions of conservatism - on the one hand idyllic and unspoiled rural environments with "poor but content" inhabitants acting as an isolated sanctuary from the evils of disease (likely to be connected to the urban or the migratory), and on the other hand rural backwardness and squalor acting as not only a direct vector for disease spread, but ignorance and reactionary qualities leading to the rejection of outside intervention (an important component behind the "preserving the ordinary" societal response outlined in Chapter 2). There exist not only differences between cinematic conceptions of rural poverty and epidemic responses, however, but also a broader contrast between the previously mentioned "conservative" rural epidemic-poor image, and the image of the "depraved" and "degenerate" urban environment, where the epidemic is often a symbol of the pressures of urban life or capitalistic exchange itself. Third, we end by linking up to the trust and cohesion discussion already offered in Chapter 3-in particular, the notion that the cinematic representation of epidemics often shows new lines of cohesion or trust horizontally among communities, but certain groups or individuals are still left out. This can be seen in the images of the poor during epidemics, where in some films poor characters are "included" and "deserving" recipients of viewer attention and sympathy, 
whereas other poor characters are presented as the "undeserving"-remaining on the margins and periphery of the film narrative. In cinema, just as in social life (Romano, 2017), solidarity tends to be limited to only those who conform to societal expectations of worthy behavior.

\section{Poverty and epidemics in early film: sympathetic and patronizing images}

The relationship between poverty and the outbreak of epidemic diseases is a subject already addressed in some of the earliest silent films, and likely situated within the context of the laboratory revolution and the growing dominance of "germ theory" at the end of the nineteenth century, but also social change creating new concerns over immigration, industrialization, and urbanization. This can be revealed in the short melodrama from 1914 that was made with the cooperation with the National Association for the Study and Prevention of Tuberculosis in the United States, The Temple of Moloch, and was part of a series of six films on tuberculosis made in collaboration with the Thomas Edison film company (Posner, 2012). In films such as these, there is a mixture of sympathy and scorn for the plight of the poor. On the one hand, we see the doctor lecturing a laborer's domestic household - urging them to stop using a collective drinking vessel and to open the windows (Pernick, 1978: 23) — and yet as soon as he leaves, the poor family revert back to their previous habits; thus, emphasizing ignorance and dubious choices. Yet on the other hand, the "villain" of the piece is still clearly the owner of the pottery factory, whose insalubrious working environment creates damp and poorly ventilated conditions conducive to the outbreak of tuberculosis among the workers through silicon dust. In this film, however, the tragedy is only truly complete when the infection is transferred from household of the poor laboring family to the factory owner's wealthier household, as his own daughter takes ill - the classic direction of spread from "underdeveloped" to "developed". The finger of blame is clearly revealed in the title: "Moloch" (from the biblical name of a Canaanite god associated with child sacrifice) used figuratively to refer to a costly sacrifice, at the expense of greed or profit. An even earlier melodrama, The Awakening of John Bond (Oscar Apfel and Charles J. Brabin, 1911), used much the same narrative device - a "slumlord" learning the hard lessons of poor living conditions for his tenants, when his own wife is struck by the disease. This format, however - with easily identifiable "good" and "bad" characters - understandably put much of the blame for disease outbreaks at the feet of individuals and their choices, rather than incisively critiquing institutions, systems, and structural conditions.

A number of early film images of epidemics and poverty were set within colonial contexts, where "civil" or "noble" behavior (usually of the colonizer) could be easily juxtaposed against perceived immorality (usually of the colonized). In The Beggar of Cawnpore (Charles Swickard, 1916), for example, a British army doctor is found battling his own addiction with drugs, but also an outbreak of cholera within a small military camp in 1850 s India. At one point the doctor is 
dragged down to the status of a beggar on the streets of Cawnpore (today Kanpur), but his recovery and personal redemption is set in contrast to the mutiny of sepoys (Indian infantrymen) working within the army of the British East India Company. Also set in India, the 1919 film The Man Beneath (William Worthington, 1919), focused in on the connection between epidemic disease and poverty by way of realism - indeed, the Japanese producer Sessue Hayakawa went as far as to cable his contacts in Calcutta to request access to all the photographs they could find of scenes taken from India during previous plagues - particularly those found 20 years previously during the 1896-1898 outbreaks in Bombay (today Mumbai) and Calcutta (today Kolkata) (Anon., 1919b: 46).

As early documentary and silent films were partially grounded in aspects of sympathy for the plight of the poor as quasi "educational" pieces, some feature films seen in the 1920s and 1930s continued with this castigation of the ills of greedy capitalistic behavior at the expense of ordinary workers and laborers, and could be positioned at either the left or right of the political spectrum. This can be seen most clearly in La Habanera (Douglas Sirk, 1937), a German melodrama set in Puerto Rico, which is one of a number of early Sirk films that have been subject to a scholarly debate on the extent to which they opposed or were complicit with elements of Nazi ideology (Lee, 2008; Rentschler, 1996: 124-145; Schulte-Sasse, 1998; Buso, 2018). The film deals with a Swedish medical team's attempts to tackle an outbreak of a mysterious and contagious disease simply referred to as "Puerto Rico fever". One of the island's most powerful and wealthy landowners, Don Pedro de Avila (Ferdinand Marian), however, becomes disconcerted by the presence of this outside investigation - fearing that the widespread knowledge of the epidemic, and the publicity generated from it, would ruin island business - in particular, the trade of a fruit export company (Halliday, 1971: 12). Indeed, we learn that previous attempts by the Rockefeller Institute to tackle the disease eight years previously had apparently led to widespread famine due to the depressed economic situation on the island - an obvious critique of American intervention and corrupting capitalistic influences. Accordingly, the wealthy and elites of the island (including the "charismatic tyrant" Don Pedro) conspire to hide the reality of the epidemic - leaving hundreds of poor island residents to die every yearand perhaps a more subtle allegorical critique of ideology and politics over science (Lee, 2008: 411). Similarly, in the Czech film Bíla nemoc from 1937, the doctor who has worked on the cure for the "White Plague" (suggested to be a form of leprosy, which is a disease closely associated with poverty) only agrees to treat the poor as a way of coercing the rich within society to put a stop to warfare. On the other side of the coin, other feature films of the 1930s, particularly from North America, instead revered those figures that turned down money or prestige in pursuit of "authentic" medical practice - especially small-scale "family" or "community" doctors such as Dr. Bull from Doctor Bull, Dr. Arrowsmith from Arrowsmith, Dr. Abbott from A Man to Remember, and Dr. Manson in The Citadel. Dr. Eli Watt (Lionel Barrymore) in One Man's Journey is presented as one of the most selfless - steadfastly treating local people, many of whom could not afford to pay for medical care, and even going as far as to raise a little girl 
(Dorothy Jordan) who was given up by a poor widower (David Landau) after the sudden death of his wife.

Some feature films by the 1930 s, however, were also starting to move in the opposite direction - instead taking a patronizing view of the relationship between poverty and epidemic disease, rather than castigating the powerful. Again, set in India, in the fictional town of Ranchipur, the opening dialogue from Major Rama Safti in The Rains Came-played by a white man, Tyrone Power-refers to the problems of "centuries of disease, and poverty, and superstition". Nevertheless, despite these associations - and specific reference to "Asiatic microbes"-we rarely see the poor and their struggle with cholera visualized (actually referred to as "plague" in the film, as a deviation from Louis Bromfield's original 1937 novel on which the screenplay is based), and instead focuses on the fates and fortunes of various individuals within the Indian social elite. The epidemic is used as a background to establish a dubious narrative of mutual respect and a future of British-Indian cooperation (McFarlane and Graff, 2012: 39, 52). These kinds of patronizing images continued in the ensuing decades, even after the Second World War, where superstitious indigenous communities are placed in opposition to the "modernizing rationality" of overarching colonial administrations - see, for example, the flattering image of French authorities in MGM's 1953 film Saadia set in Morocco (Cowans, 2015: 187).

Patronizing views were also shared in the film Pacific Liner-again produced in 1939 — based around a drama set on a ship, "The Arcturus", bound from Shanghai to San Francisco in 1932. It is likely no surprise that the cholera outbreak on this ship was said to be caused by an infected Chinese man (played by Miki Morita), hiding away below decks - unsurprising on grounds of his "Chineseness" (like in The Rains Came, the doctor emphasizes "Asiatic" in his diagnosis), but also unsurprising on the grounds of his impoverished situation that he apparently was trying to escape from. Much of the film narrative continues along the lines of strong socio-economic divisions - the wealthier passengers are sheltered above, while cholera spreads quickly among the poor fire stokers in the belly of the ship below. In one of the classic lines of the film, one of the workers announces: "Listen to them dancing, on the lid of a coffin". In the film, we see some clear examples of strong resistance towards elite or authority figures - the subject of Chapter 2 - as many of the workers decide to mutiny against the orders of the physician, Dr. Tony Craig (Chester Morris). In one heated scene the workers fling hot coal at him and refuse to shovel, and engineer "Crusher" McKay (Victor McLaglen) then proceeds to throw an angry punch. Interestingly, in a period when Hollywood films tended to reinforce racial stereotypes, the potential for racial othering of the black stoker (Ernest Whitman) is outweighed by his socio-economic position as "one of the workers". In one scene, a dying stoker remarks in the sick bay, with apparent surprise, that "you're trying to help me just as much as the rest of them [the white stokers]" (Nollen and Nollen, 2020: 136). The film, however, creates distinctive contrasting images throughout — we see dead stokers and their bedding being fed into the boilers, and one man desperately fleeing the disease by abandoning himself to the sea, and yet the film does not reflect long on their sacrifice. 


\section{Urban depravity and rural backwardness}

Instead, these images can be placed against the final scenes of the film, where the ship is praised for arriving two hours ahead of time and the quarantine measures were so "effective" that the passengers on the upper decks were blissfully unaware of the tragedy that had occurred below-and that is the curious message that the film ends with. Of course, this might also be interpreted as a thinly veiled critique of the selfishness of privilege, and a demonstration of the unrecognized contribution of medical, engineering, and laboring personnel alike.

\section{Between the idyllic escape and the squalid countryside}

The rural environment has served as an important physical context in which the connection between poverty and epidemic disease has played out in cinema. In some cases, particularly in films seen before the Second World War, the countryside has been used as a form of rural idyll - a tranquil and unspoiled refuge from cities much more conducive to the spread of disease, through proximity to the poor and the twin association of insalubrious living conditions and dubious lifestyles, morals, and practices. Traces of this view can be seen in classic literature of the early twentieth century such as the "sanatorium of the wealthy" and the "ideal society" portrayed in Thomas Mann's Der Zauberberg [The Magic Mountain], started in 1912 and completed in 1924, but also taken on, developed, and critiqued in the more contemporary work of Roland Barthes - his 1977 lectures Comment vivre ensemble [How to Live Together], for example (Knight, 2008: 54). Already from the late nineteenth and early twentieth century, "fresh air" was commoditized as a potential cure for disease, and moreover, in combination with the rural environment, was reframed as a space for "freedom" (Tworek, 2019: 823).

The very earliest silent films tended to subscribe to this view-such as the "Edison Six" series mentioned earlier. One of the most relevant examples can be found in Hope, A Red Cross Seal Story (Charles J. Brabin, 1912), when a small-town banker (George A. Lessey) is asked for a charitable donation to help against tuberculosis, he incredulously refuses on the grounds that the affliction was an "affliction of the poor" in big city slums (a common view found in the early twentieth century), not in "wholesome" provincial town America. This later proves to be a mistake as his fiancée, Edith (Gertrude McCoy), eventually becomes afflicted, despite apparently coming from a relatively privileged country home. But the same trend appears in later films too as we move into the 1930s. In John Ford's Arrowsmith, for example, sleepy small-town America is presented as something wholesome and decent, and a clear contrast to both the cut-throat world of scientific research (where morals and ethics are brought into question) and the impoverished fictional island in the Caribbean, where plague is running rife. This is seen on two occasions; Dr. Martin Arrowsmith's retreats from the competitive world of science at the beginning of the film, as he takes up a mediocre position in a medical practice in a rural community in South Dakota, and then at the end (and developed more in the original 1925 book by Sinclair Lewis), where he turns down fame and fortune to escape to the backwaters of Vermont to work by himself-spurning even the attentions of his second wife. In another 1930s 
film, Green Light, disgraced surgeon, Newell Paige — played by Errol Flynn — is forced to leave his high-profile Massachusetts hospital (taking the blame for a botched operation carried out by his mentor), but finds personal and professional redemption dealing with Rocky Mountain spotted fever in the isolated and rural communities of Montana.

This notion of a rural escape from an epidemic-inducing environmentfrequently linked to urbanity and poverty - is similarly seen in other early films such as the various adaptations of the original nineteenth-century story, Storia di una capinera, and is one of numerous writings Giovanni Verga made on the connection between afflictions such as cholera and malaria, poverty, and economic precarity in southern Italy (De Vito, 1969). In Storia di una capinera, the young female protagonist, a nun, escapes from the cholera-ridden environment of Catania in Sicily, and returns to her family villa in the countryside close to Mount Etna. The beauty and tranquility serve as a significant contrast to the darkened images taken in Catania - but also serve as the background to her decision to return to the claustrophobic convent (Greenfield, 2014: 9-10), with all its dangers, restrictions, and lack of freedoms. It is determined that it is precisely amongst the urban poor that Maria's calling is best served.

Elsewhere, in Die Hamburger Krankheit, it is no accident that the director Peter Fleischmann moves the direction of travel of the main protagonists (one being a money-obsessed pimp, presented as the "worst capitalist possible": Scharf, 2008) from the infected city of Hamburg in search of escape in the beauty-perhaps innocence - of the southern Bavarian mountains. This is one of the starkest contrasts that could be established in German cultural topography. While nature provides positivity, and thus a shield from the disease, the sickness took root in the rhythms and culture of the port city of Hamburg itself - the director's critique of a society with few positively reinforcing experiences. These themes of escaping the disease-ridden confines of the city were similarly established in The Ultimate Warrior (Robert Clouse, 1975), where a group of survivors in New York, post global pandemic, need to escape the ruined and increasingly lawless settlement by heading for a small rural island next to the coast of North Carolina. The concept of "rural replenishment" is emphasized by the fact that the lead scientist of the film, Cal (Richard Kelton), develops some disease-resistant seeds that can grow in their new society's barren soils. These kinds of themes continue even in very recent popular culture visualizing societal responses to epidemic outbreaks. For example, in a popular Russian television series from 2019 about a virus spreading from Moscow, Эпидемия [Epidemiya/To The Lake], the wholesome nature and healing capacity of the countryside is placed in contrast to the poisonous urban environment full of deviance and debauchery (Souch, 2021).

In a twist on these themes, the Swedish Himlaspelet, based around a disease outbreak in a seventeenth-century village, appeals to nostalgia and a perceived loss of a more "innocent" agrarian past (Steene, 1999: 92). The descent into scapegoating — burning alive a blamed woman, Marit — leads the main male character (Rune Lindström) into his own personal struggle with the loss of morality within his own rural community. Similarities can be drawn with another 


\section{Urban depravity and rural backwardness}

Scandinavian film, Trollsyn, where the Black Death outbreak and the moral decline of the village stand as clear contrasts to the concepts of an egalitarian, self-sufficient, and "innocent" community - according to Rees (2003), established by the director's emphasis on orality (over literary tradition) and the use of a west Norwegian dialect "Nynorsk".

Yet the countryside in other early films have served not as the physical and cultural escape from disease, poverty, and immorality, but as the very environment bringing these concepts together - that is to say, rural underdevelopment has also featured significantly in the links between disease and poverty in cinema. Here focus tends to be put on ignorant practices, pseudo-scientific or superstitious beliefs, and a lack of civility, perhaps extending even into "barbarism" - and thus a moralizing or even patronizing view of rural lives. Short films from the $1930 \mathrm{~s}$ such as Las hurdes: Tierra sin pan (Luis Buñuel, 1933) deliberately exploited a "pseudo-documentary" format to scrutinize the lives and decisions of poor rural communities. In this case, the film centers a quasi-anthropological view (likely exaggerated for political effect) on the isolated mountain town of La Alberca and nearby villages in the Las Hurdes region of central-western Spain - at one point reflecting upon a certain "ignorance of instinct" as inhabitants contract dysentery from eating local cherries from bushes. ${ }^{1}$ We also see recurring cases of gout and malarial fevers. According to director Buñuel, these "wretched" peasants are incapable of ceasing to do what harms them - despite being conscious of the factand therefore are apparently acting in the same way as an animal (Begin, 2007: 439). While early documentary and silent films of the twentieth century saw the poor as victims of dubious business practices, for example, by the 1930s many educational and feature films saw epidemic disease as something, at least partially, perpetuated by the (poor) choices the poor were making.

In this early documentary of Buñuel, we see parallels with the later Italian film, Cristo si è fermato a Eboli (Francesco Rosi, 1971), based on the memoir of Carlo Levi (published in 1945, but referring to his political exile in 1935-1936) and his time residing in the impoverished villages of the Basilicata interior in southern Italy, with its emphasis on superstition and ignorance, leading eventually to outbreaks of diseases such as malaria. Indeed, environmentally specific diseases such as malaria have proven to be significant contexts through which the plight of the poor and the marginalized have been screened. In the Brazilian film, Gaijin-Caminhos da liberdade (Tizuka Yamasaki, 1980), social realism is employed to depict for the first time the lives of poor Japanese immigrants working in Brazilian coffee plantations at the turn of the twentieth century. Rather than the rural idyll, many of the migrant protagonists attempt to escape the confines of an isolated and degrading environment - threatened always by various fevers - and instead look for a way of culturally assimilating into the city through hard factory work. And returning to Italy, links between peasant life, "ghostly" open plains, and malaria epidemics are developed in Mal'aria (Paolo Bianchini, 2009) - set within the context of the Ravenna marshes in the 1920s (an association with the disease going back centuries: Squatriti, 1992)_-but instead borrowing from horror genres rather than social realism. 
Accordingly, the rural idylls already described and seen in Arrowsmith - or even the gossipy and conflict-inducing provincial small towns served by local doctors in Doctor Bull or A Man to Remember - contrast with other kinds of views such as that seen in the roughly contemporaneous British film The Citadel, where a poor mining village in south Wales is presented as a rural environment "ripe" for outbreaks of disease (in this case tuberculosis). The emphasis on the conservatism and, perhaps ignorance, of the poor workers is emphasized in one scene where Dr. Manson - an "outsider" Scottish doctor - has his notes and laboratory demolished by the miners, which prompts him to move back to the "sanctuary" of London. A.J. Cronin — author of the original novel on which the film was basedhad direct experience of this environment, and was aware of the notoriety of the Welsh valleys as a place of insolent resistance to the work of medics (McKibben, 2008: 664). Interestingly, wealth and poverty remain a key theme within the narrative of The Citadel, even after the story moves away from the Welsh miners: Dr. Manson is effectively seduced by the lure of money treating rich hypochondriacs, and only the tragic death of his diligent and ethical friend, also a doctor, convinces him to return to more meaningful work treating poor patients living in squalor.

Many of these same trends are discernible in later films set in the Middle Ages - film protagonists frequently encounter impoverished rural communities stricken with plagues: see, for example, the knight returning from the Crusades in Bergman's The Seventh Seal, where they bear witness to disease and social decline in equal measure as a woman is burned at the stake for consorting with the devil (Cooke, 2009: 163). In plague-afflicted fifteenth-century France depicted in The Hour of the Pig, the main protagonist of the film, Richard Courtois (Colin Firth) leaves the "decadence" of Paris to practice law in a tranquil rural village, only to be convinced to return to the city and not "waste his life" among ignorant and superstitious peasants. In the Italian cult-classic L'armata brancaleone (1966), director Mario Monicelli even makes fun of this notion: a group of bandits prepare to ransack an impoverished Apulian village, and yet upon learning that the community had recently been devastated by a plague, decide to make a hasty and cowardly retreat.

In recent African cinema, such as the recent 93 Days (Steve Gukas, 2016) based on real events from Nigeria, for example, we see an undercurrent of fear over large modern commercial urban centers exhibiting vulnerabilities in a chain of Ebola infection moving from more impoverished rural areas of Western Africa. We hear at the beginning of the film a woman setting the scene as camera pans out across a bustling and busy city: "This is my city, Lagos. Over 21 million people call this city their home. Over 21 million people, tight packed and pressed together". The viewer immediately is encouraged to see this place as (a) vulnerable, (b) a significant commercial hub, and (c) innately and uncontrollably pathogenic, and the potential site of a "perfect storm" of conditions that could amplify Ebola transmission (Herrick, 2019). Not long into the film, we encounter a LiberianAmerican diplomat (Keppy Ekpeyong Bassey), recently flown in from Liberia, who is clearly sick. Despite the ongoing Ebola outbreaks in Liberia, however (the film is set in 2014), it is not immediately assumed that he is infected with this 
disease. Even Dr. Ameyo Adadevoh (Bimbo Akintola), who is credited with placing the diplomat, Patrick Sawyer, in quarantine despite pressure from the Liberian government, shows restraint at the beginning - telling her son "It's not like he's some farmer from one of the villages ... he's a diplomat, so [it's] probably not [Ebola]". Interestingly, we see here Wald's "outbreak narrative" in full view-the direction from a clearly demarcated "underdeveloped" to "developed"- and yet these are not external European, North American, or East Asian ideals but a view established within "Nollywood" itself.

In other films, however, the lines between the rural idyll and rural underdevelopment become much more blurred - something shown in the numerous adaptations of the nineteenth-century Alessandro Manzoni novel, I promessi sposi (in 1923, 1941, and 1964, as well as a television series in 1989), based around a severe plague that occurred in northern Italy in 1630 (on its background and relative severity: Alfani, 2013). In the beginning of the story, the rural community located somewhere in the mountain areas close to Lecco, near Lake Como, is presented as backward and immoral - the absence of injustice and the rule of arbitrariness revealed by the fact that an honest but not wealthy couple, Renzo and Lucia (Dina Sassoli), wish to marry each other, but are prevented by the interference of a local baron, Don Rodrigo (Enrico Glori), who has his own sights set on Lucia. The couple flee the corrupted rural community, but along the way, also find moral ambiguities on their travels - and injustices and hardships also within the urban environment of Milan. Lucia is kidnapped - after a nun is coerced into tricking her. Meanwhile, Renzo experiences both a popular uprising connected to famine conditions, where a mob begins to riot and attempts to loot bakeries (see Figure 6.1), and then the outbreak of plague - where his impoverished appearance creates suspicion that he is an outsider deliberately trying to spread the disease, along with other "untori" (spreaders) (De Vito, 1969: 286). ${ }^{2}$ In I promessi sposi, the rural and urban environment matters little for Renzo and Lucia-with the overarching message of the story being that the poor rarely can escape injustices inflicted upon them by the wealthy and powerful. In the original text, Manzoni asserts the importance of providence - and how it is only the intervention of the gift from God (a plague) that can offer a small piece of divine justiceemphasized by the fact that Renzo forgives those that have wronged him, as they die from the disease.

Comparable tendencies towards framing epidemic outbreaks as the logical outcomes of sharp polarities between wealthy "landed" classes and peasants and the laboring poor were seen in the North Korean film, 소금 [Salt] (Shin Sangok, 1985), based on a 1934 novel by Kang Kyeong-ae. The story is set in the 1930s Kando (today part of the People's Republic of China, and referred to as Yanbian), where ethnic Koreans experienced the persecution of Japanese occupiers and Chinese bandits. The whole film from start to finish is an exercise in incessant miserabilism, as a poor rural woman (Choi Eun-hee) (who has already suffered the loss of her husband, abandonment, incarceration, forced labor, and rape) eventually loses her daughter and newborn who succumb to an unnamed epidemic virus - the corpses carted away in tiny coffins. ${ }^{3}$ The poverty leading to 


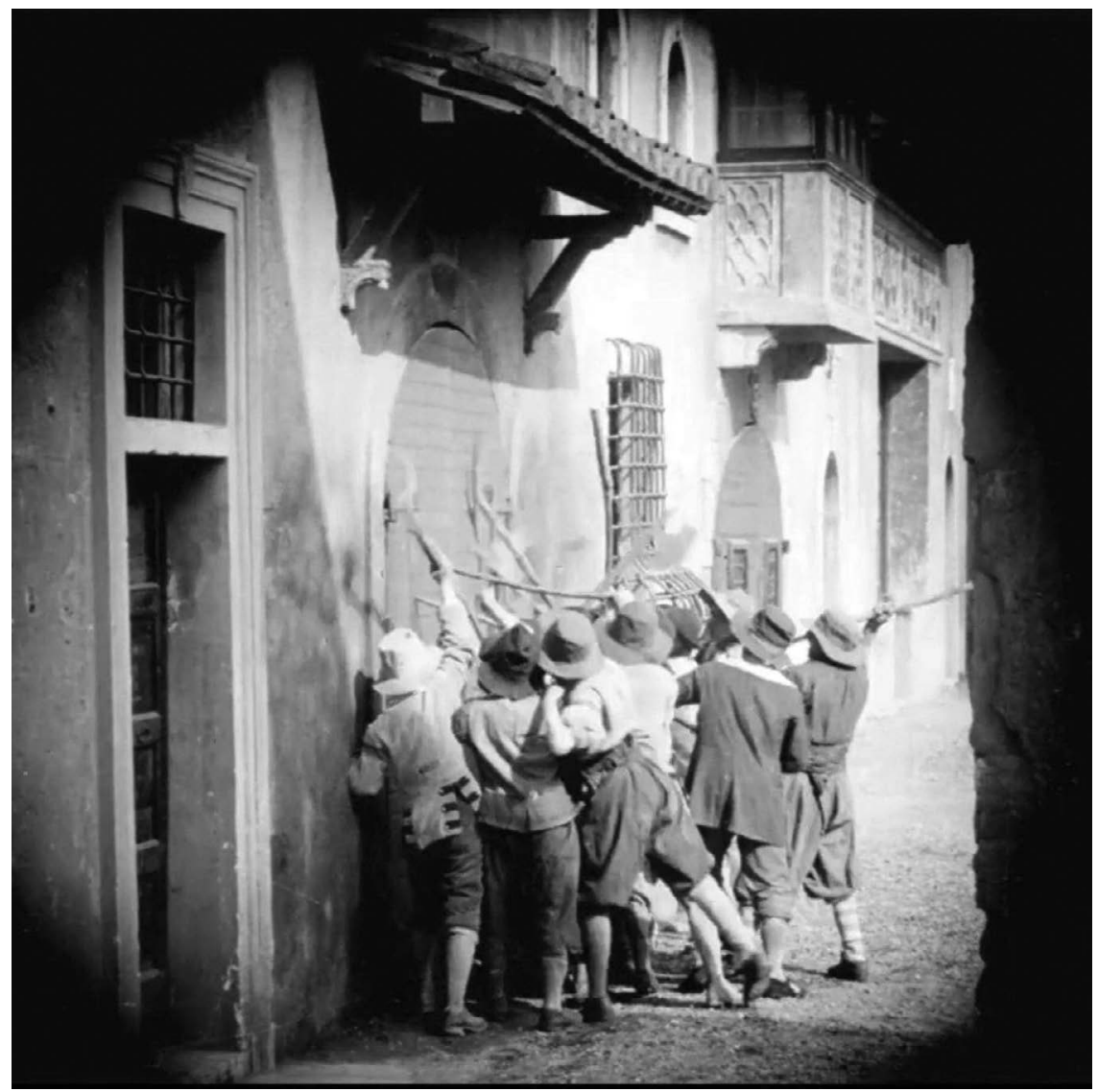

Figure 6.1 "Raiding the bakeries" in I promessi sposi (Mario Bonnard, 1923)

Source: Captured from personal collection.

the disease is framed as a logical product of the landowners' callous indifference to the mother's dreadful situation-instead inflicting further violence and injustice upon her-and the medical practitioner's refusal to administer treatment or medication to the children (Chung, 2014, 2009: 94-95).

It should, however, be emphasized that the connection between rurality and epidemic disease holds contextual significance within different cinematic traditions. Upon the founding of the People's Republic of China in 1949, many filmmakers in the mainland focused heavily on the scourge of epidemic disease for the rural poor - in particular the blight of schistosomiasis (caused by water-borne parasitic flatworms) - but also early childhood infections (death rates of roughly $25 \%$ at this time for infants less than a year old in rural areas: Johnson and Wu, 2014: 56). The root out of this problem was to be found in socialist medical advances-a 


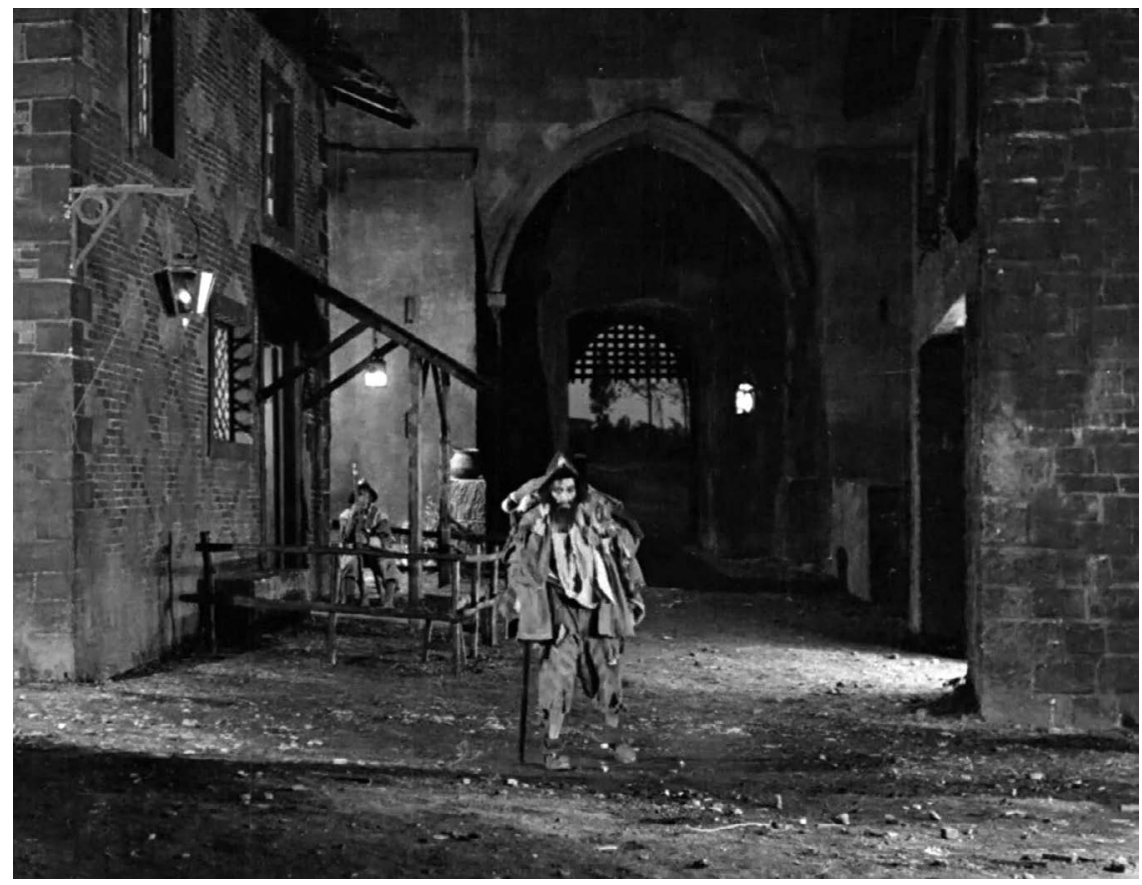

Figure 6.2 "The plagued soldier" in I promessi sposi (Mario Bonnard, 1923)

Source: Captured from personal collection.

rural modernization narrative - as seen in the rustic pictures Willows in the Spring Breeze and Spring Comes to the Withered Tree (Qin, 2012: 366); part of a number of films produced with state approval in the "post euphoria" famine years of the Great Leap period, but also later productions such as 雁鸣湖畔 [Yanming hupan/ By the Yanming Lake] (Gao Tianhong, 1976) and 青春 [Qingchun/Youth] (Xie Jin, 1977). In Spring Comes to the Withered Tree, the poor peasant woman, Meizi, is afflicted with schistosomiasis, and is not helped by two urban "bourgeois" physicians from Shanghai, but instead benefits from a local cure - the key protagonists being the village head, a young tractor driver named Dong, and the paternalistic instructions of Mao Zedong himself, instructing the community to work as a true collective (Pickowicz, 2006: 1065-1066).

Many of these films also integrated the exploits of "barefoot doctors" (on this subject in cinema: Fang, 2019; Pang, 2014) —some with unexpected nuances. For example, in one of the most illustrative films, Red Rain - directed by Cui Wei, one of the few filmmakers that continued a productive career both before and after the Cultural Revolution - reflected on the experiences of a young "barefoot doctor" working in a mountain village in rural Hunan, and shows Hong Yu winning over initially skeptical and resistant peasant villagers. Although some of this 
film—like others such as the contemporaneous 春苗 [Chun miao/Spring Shoots] (Xie Jin, 1975) — presents an inevitable struggle between Western and Chinese medical practices (integrated within a broader antithesis between city and countryside, and depicted in a longer Chinese cinematic history: Zhang, 1996: 11), actually much of the "enemy" in Red Rain is an older herbal tradition, representative of a conservative age before the emergence of the "new" China. Most of these films foregrounded male rural doctors, ${ }^{4}$ and in reality, most were indeed men (Pang, 2014: 809), but paintings, posters, and even postage stamps also portrayed women as working in revolutionary new professions connected to healthcare in these kinds of idyllic rural settings, as seen in Figure 6.3 from 1974 (contextualized in Andrews and Shen, 2012: 197; Gross, 2018: 358), and a form of female representation that found parallels in many other rural social and economic roles (see the "female tractor driver image", for example, in Yan Du, 2017). In that sense, the Chinese representation of poverty and epidemic images has tended to offer partially contradictory narratives: the escape from a version of the rural seen as backward and conservative, but at the same time creating a quasi-nostalgic vision of a "timeless" idealized and tranquil rural arena (Han, 2021). ${ }^{5}$

\section{Urban depravity and degeneration}

Increasingly from the 1970 s onwards, epidemics on screen no longer solely held the blurred position between the two elements of rural impoverishment - the simple idyll and the underdeveloped squalor — as these outbreaks become instead

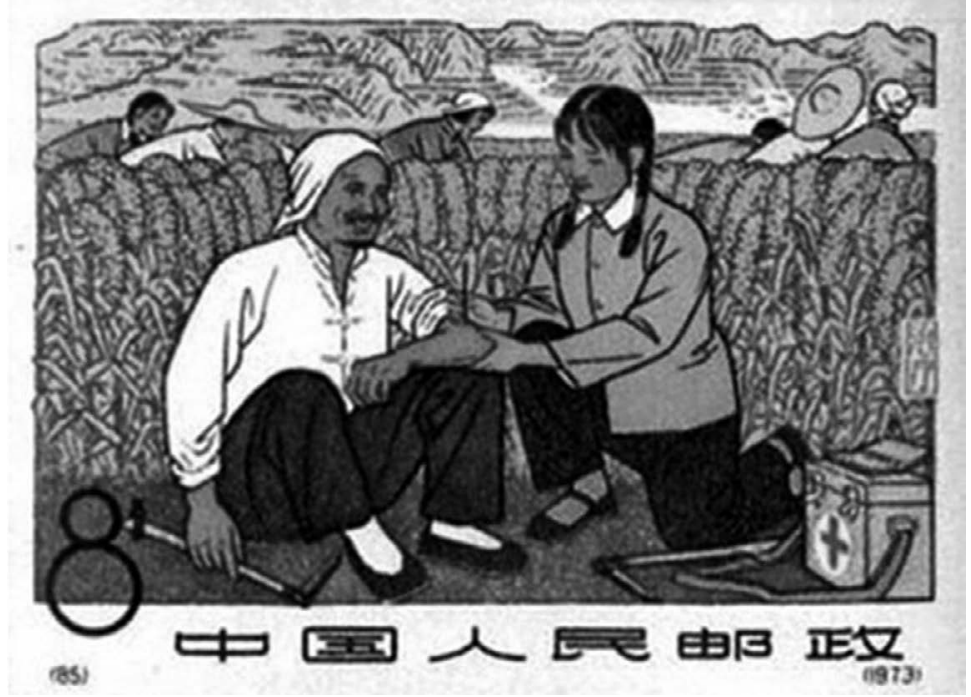

Figure 6.3 Female "barefoot doctor" stamp, 1974

Source: Photo from the collection of Miriam Gross, reproduced with her permission. Accessible at (Gross, 2018: 358). 
linked with the depravity and degeneration of urban life. While in the rural context, the environment was either the escape from or the direct cause of the outbreak, quite often an epidemic disease outbreak in these films becomes a metaphor for the penurious and pitiful position of the poor inhabitants that are resident within the city itself (Sontag, 1978: 74). Urban development, while on the one hand signifies mastery over the natural environment and the creation of the modern industrialized landscape, it cannot on the other hand be separated from a simultaneous narrative of human exploitation (Williams, 1973: 37) - thus the sickness in these films is often seen to be found as an intrinsic component of capitalistic forms of modernity. More recent films such as those set around particular economic spaces within London such as Shaun of the Dead and 28 Days Later, for example, can be seen as (very different) critiques on the accelerating viral nature of global capitalism (Boluk and Lenz, 2010), although versions of this same anxiety towards post-industrial consumer society can equally be found in many of the original Romero zombie films from the 1970s (Conrich, 2015: 16-17). Indeed, the link between infection and inequalities has been frequently foregrounded through the different genres of zombie cinema, where survival narratives reflect how power and privilege influence disease spread and prevention (Wonser and Boyns, 2016: 640). ${ }^{6}$ In one scene from Dawn of the Dead, for example, we see Fran Parker (Gaylen Ross) exclaim "What the hell are they?!" upon seeing a zombie-infested plaza (frequently occupying open communal spaces: Conrich, 2015: 19), while Peter Washington (Ken Foree) rather cynically answers, “They're just us, that's all" (Boluk and Lenz, 2010: 138). Zombies depicted in the recent development of pandemic horror movies are frequently visualized down the lines of wealthformer members of the "middle class" now tatty, dirty, and emaciated in their zombie state (Höglund, 2017).

An extension of this issue is the critique in some films (especially from the 1990s onwards) of an indebtedness to ideologies of individualism - and a criticism in particular of the idea that recovery from debilitating disease should be a personal burden of self-responsibility rather than a communal preoccupation (Grossman, 2005; Naismith, 1998). We see this, for example, in the 1995 film, Safe (Todd Haynes, 1995), where an affluent suburban housewife (Julianne Moore) starts to develop a sickness from a disease directly connected to the environment surrounding her. Interestingly, the film also reflects upon the marginalized status of a number of peripheral characters - Latin American maids, caterers, and laborers, an Asian American dry cleaner, a Caucasian taxi driver, and a black medical assistant - with the suggestion that whatever difficult experiences the suburban housewife is going through, she has at the very least the luxury of the viewer identifying and "recognizing" her problem (Seymour, 2011: 33). Many of these issues tend to be foregrounded through the visualization of blurred lines between public and private, shared and exclusive spaces - as seen in the recent German zombie-infection film, Rammbock (Coleclough, 2021).

One of the best examples of the urban depravity narrative can be found in the Mexican film from 1979, El año de la peste, which focuses on a city's struggle to deal with the spread of a virus - a struggle intensified by the interaction of 
socio-economic inequalities, corruption, bureaucracy, and the dysfunction in political institutions. Across the course of the film, we see poor neighborhoods devastated - often through the over-zealous intervention of political, medical, and legal authorities - and this is juxtaposed against the conditions of the wealthy, who make sure their families are able to evacuate abroad. In one scene we even see the rich cordoning off a hospital with plentiful resources to themselves, while in other scenes the dead are carried off by municipal garbage trucks - reduced to literal "trash". One of the deliberate techniques of the film to emphasize the lack of empathy from the governmental authorities towards the people they are supposed to care for is to push the suffering of ordinary people off the screen-where the state-controlled media messaging instead presents the public health crisis in terms of numbers of statistics rather than as individual stories. In fact, the impoverished infected are treated as "sources of evidence" in themselves, and thus tend to be isolated or locked up out of view-with some resorting to suicide rather than falling into the callous hands of the authorities (Rocco, 2014: 78). In that sense, the director, Felipe Cazals, uses the epidemic disease to critique disparities in wealth and arbitrary expression of power, leading to pollution, ecological destruction, and unrestricted urban growth, and epitomized in one character's, perhaps unsubtle, assessment: "As long as the political bureaucracy manipulates institutions as their own plaything for the benefit of the ruling class to which they belong, this country will continue to be screwed". The final critique, employing dark humor, can be seen at the end of the film when we learn that the disease was caused by someone profiteering by trying to sell a stock of toothpaste after its expiration date (Mora, 2005: 168).

The association of a distinct form of urban life and development with sickness was something also found in East Asian cinemas of the final third of the twentieth century. One such example of this can be seen in Lung Kong's Yesterday, Today, Tomorrow, set in Hong Kong in the late 1960s, which allegorized the anticolonial riots of 1967 as a form of plague infesting Hong Kong society. The film eventually was censored (changing its title from The Plague) and severely edited under pressure from two sides: the British colonial authorities that obviously took exception to the foregrounding of the riots (even as an allegory), and the Chinese mainland Xinhua News Agency, which took exception to the emphasis on local exceptionalism - the creation of a separate Hong Kong citizen identity and belonging (Cunliffe, 2020: 51). In order to subvert censorship, the director, Lung, had to provide a positive framing of an idealized space where people from all walks of life - authorities from above and ordinary residents of the city - had to unite to overcome this disease. In one scene depicting a public health news bulletin, the film cuts away to various social groups of differing social and economic statuses: the message seemingly "we are in this together" as an "imagined community" (on this concept: Anderson, 1983).

However, Yesterday, Today, Tomorrow still finds ways of associating urban life, poverty, and an epidemic outbreak together - the use of gritty on-location camera work that allows, under the surface, for a condemnation of social inequalities perpetuated by a colonial form of capitalistic extraction. Although plague is a 
metaphor for the rioting, the rioting is also a product of ingrained social tensions perpetuated by inequality (Cunliffe, 2020: 52) — and indeed, the actual events of the riot of 1967 were instigated by a labor dispute and strike. Thus, Yesterday, Today, Tomorrow was arguably one of the first Hong Kong films to reflect upon the economic gap between rich and poor-as others followed in its wake such as the kung fu film The Delinquent (Cheh Chang/Chih-Hung Kuei, 1973) and crime drama The Teahouse (Chih-Hung Kuei, 1974). This idea for an epidemic outbreak in Hong Kong was informed by Lung's vision of the real-life squatter habitations, and the contaminated water sources that often occurred during shortages: the director later describing it as a "plague waiting to happen" (Cunliffe, 2020: 60). Indeed, despite the savage cuts to the film, still retained were images where the disease takes root—-shot on location outside the studio — with glimpses of slum conditions, crowded living quarters, and images of economic hardship in the frantic struggle to acquire food. Ironically, the erratic and over-zealous cutting of film scenes only serves to add to this scene of chaos - disrupting the flow of the narrative and helping develop a whole new image of urban decay with those on the fringes of society.

Given the political context of its film production, Yesterday, Today, Tomorrow's social critique was tempered by some positivistic framing - not least the notion of a form of distinctive civil society that could overcome and eradicate the plague within. If we move 30 years later to the appearance of the Taiwanese The Hole, set in Taipei on the cusp of the millennium and dealing with a virus spread through cockroaches, no such positivistic concessions can be seen-it is relentlessly unsympathetic. The film, which was nominated in 1998 for the Palme $d$ 'Or at Cannes, uses the disease as a critique of urbanized society prevailing in Taiwan - and in particular brings into view those left behind in the pursuit of development (Chang, 2008: 26; Ganjavie, 2012: 40). We learn from the very beginning that the government is using heavy handed methods - cutting off water and stopping garbage collection-to forcibly move poor tenants of an apartment block to a temporary quarantining site. However, the two protagonists of the film, who refuse to move, not only have been abandoned by the authorities - but have also been lost in the rhythms of urban life itself, which is perhaps the root of this insidious disease now coming to the surface. It is no coincidence that the epidemic is spread via cockroaches as the vector-symbolic of the dank, damp, dark, and dilapidated residences that the poor reside in - but the disease also manifests itself in "cockroach-like" symptoms of people, who retreat under beds, confine themselves in isolated corners, or hide away in the sewers. ${ }^{7}$

The disease at the heart of urban society is, it seems, the oppressive environment, creating a lonely and dreary existence where people have lost the means of connecting with others around them. Critiques of this insular life can be seen in scenes where the television advertising is fixated on promoting instant noodles, where we hear "just one pack if you're cooking for yourself!". The man in the upstairs apartment (Lee Kang-Sheng) is reluctant to open the door to anyone (in the opening scene walking around in his underwear), his apartment is littered with beer cans and cigarettes, and his major point of communication and contact 
(besides the woman downstairs) is with a cat, who he strokes and feeds cans of sardines. The struggles of the woman downstairs-hoarding noodles and toilet paper, eating instant noodles alone, and dealing with her peeling wallpaper through the dampness - is cleverly juxtaposed with fantasies of choreographed Hong Kong pop songs reminiscent of the 1950s and 1960s performed by film star and singer Grace Chang, with colorful dresses and joyous expression, that serve to accentuate the grim contemporary reality and perpetuate a nostalgic longing for something innocent and lost (see Figures 6.4, 6.5, and 6.6). This is brought out

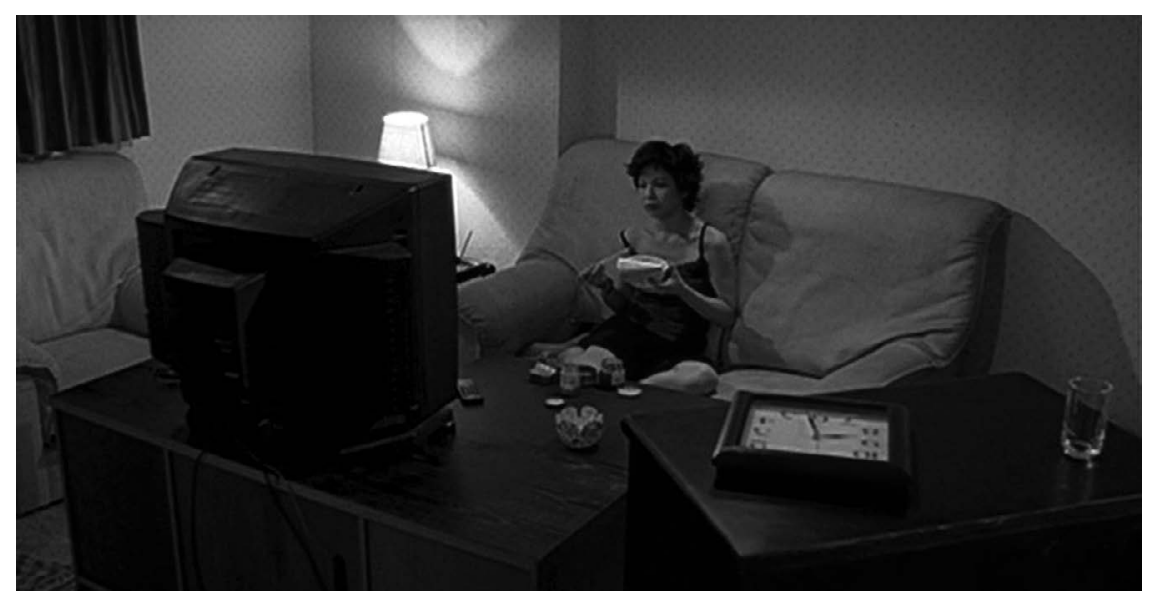

Figure 6.4 "Noodle for one" in 洞 [Dong/The Hole] (Tsai Ming-liang, 1998)

Source: Captured from personal copy.

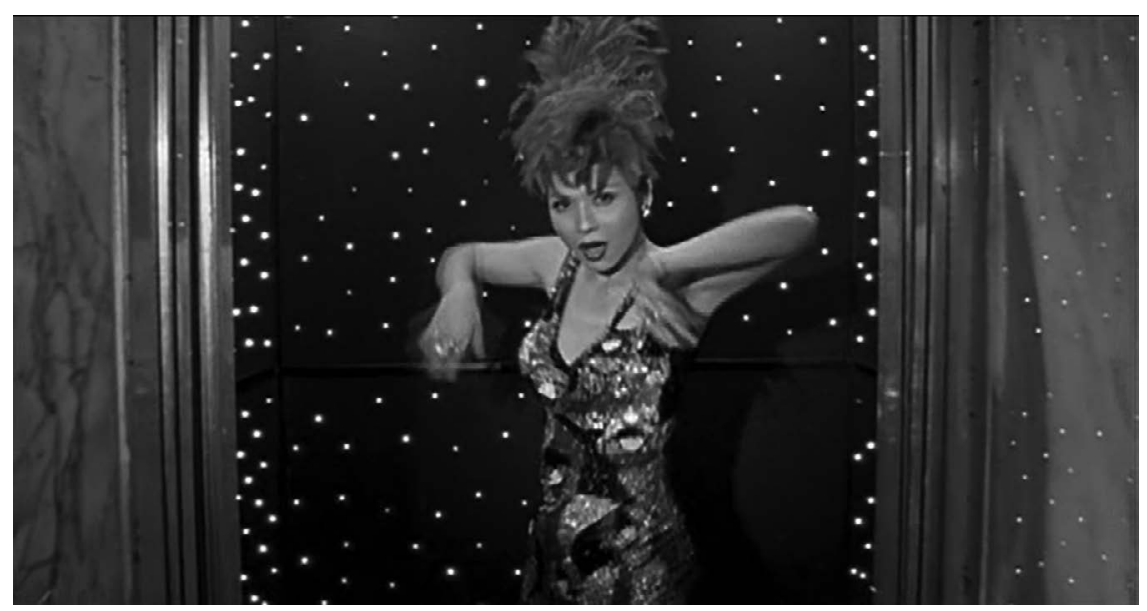

Figure 6.5 “Grace Chang scene 1" in 洞 [Dong/The Hole] (Tsai Ming-liang, 1998)

Source: Captured from personal copy. 


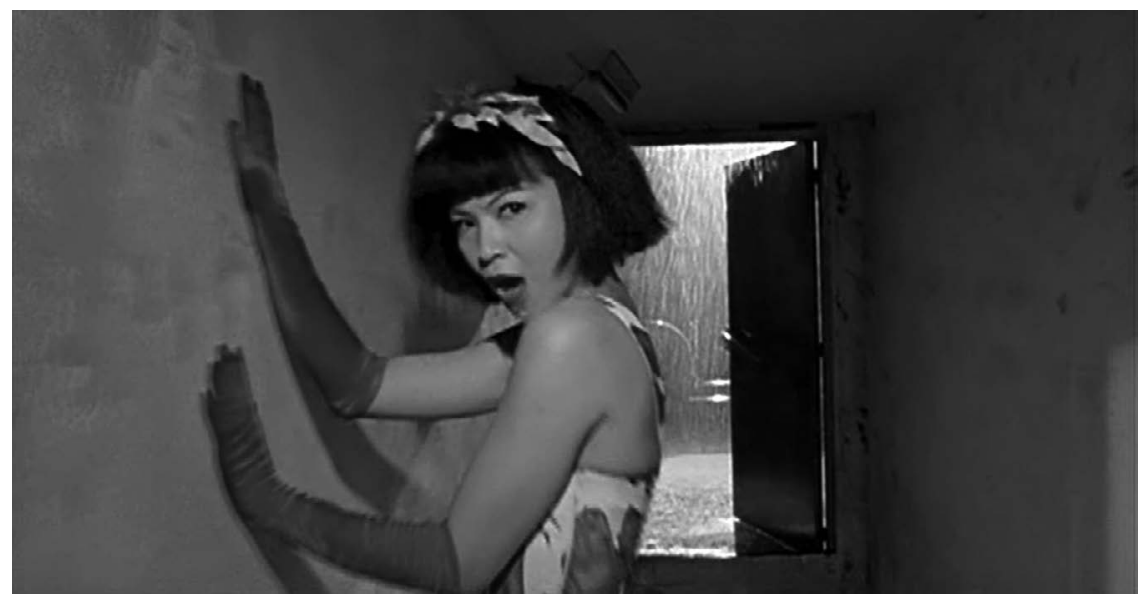

Figure 6.6 "Grace Chang scene 2" in 洞 [Dong/The Hole] (Tsai Ming-liang, 1998)

Source: Captured from personal copy.

very clearly in the dance scene depicted in Figure 6.6, where the bright red floral dress and cheerful pop sensibility is contrasted with the grim corridor and the torrential rain outside. Indeed, director Tsai employs dark humor before the credits of the film roll, leaving a note on the screen for the audience: "In the year 2000, we are grateful that we still have Grace Chang's songs to comfort us". Ultimately, then, the epidemic brings into view the intense isolation of the man upstairs and the women downstairs, but their enforced retreat into their own squalid homes opens a new line of communication between them both - as, accidentally, a hole starts to appear in the floor of the apartment above that allows for forms of visual, oral, and in the end, physical contact. Indeed, the hole becomes the last desperate means of communication-moving from a symbol of voyeurism, desperation, and depravity to a symbol of hope and salvation - and as the man pulls the woman up into his apartment at the end, their last slow dance together can be seen as one final act of defiance against failed humanity.

\section{The deserving vs. the undeserving poor}

The urban depravity narrative has tended to visualize the epidemic-poverty link as something inevitable and inescapable for the urban poor-victims of misfortune and structural inequalities and injustices, which the disease outbreaks help bring to the surface. Poverty is not monolithic and homogenous, however. In certain films, such as the controversial mid-1990s film Kids, the spread of HIV among the urban youths was not necessarily attributable to institutions or systems - at least not directly — but a product (and symbol) of existential alienation and general misanthropy. Most of the film protagonists are found "punching down" on victims-a 
cacophony of violence, rape, coercion, and tricks (Halper and Muzzio, 2013: 15) - rather than striving for their place within unjust or unequal "structures".

In more contemporary cinema connected to epidemic disease, the poor have on many occasions faded into the background of the film narrative. If we look to the most recent version of The Painted Veil, for example, the film is set predominantly within the confines of an isolated poor 1930s village somewhere in the southern interior of China, and yet we do not get to know any of the poor villagers at all. The only time that these villagers are brought into the viewers' consciousness is during mass collective action-reflective of a homogenous and faceless whole - either stirred in anger and resistance against the policies of the foreign bacteriologist and the army, or as a threating unruly force liable to do harm to the westerners present within the village. In that way, rather remarkably, the 2006 film does not deviate that far from the representation of the "faceless collective" of Chinese villagers depicted in the 1934 original starring Greta Garbo - the original poster presenting the dark shaded faces of the peasants, and their dubious intentions realized with one of them wielding a knife in the direction of the Western bacteriologist (see Figure 6.7). This kind of expressionless face has long been used in films depicting poverty and disease in an Orientalist perspective, across a variety of filmmaking cultures. For example, in the Soviet film Дни затмения [Dni zatmenija/Days of Eclipse] (Alexander Sokurov, 1988) this same aesthetic is used to create a form of squalid "barbarism" as we follow a Soviet pediatrician making his way through a "hostile" backwater of an area now belonging to Turkmenistan (on face and faciality as an exposure of human relationality in Sokurov's films: Iranzo, 2017).

This is important to reflect upon because the place of the poor within epidemicrelated films is not solely dictated by wealth alone, and not simply presented as inevitable victims. Indeed, infectious diseases presented within contemporary cinema also tell us something about who is seen as the "deserving poor"-deserving of resources, help, and support in the film and deserving of the viewer's attention and sympathy - and who is the "undeserving poor", and therefore destined to fade into the periphery of the film narrative. Already mentioned is the example of Safe, and the juxtaposition of the problems of the Caucasian suburban woman (who is centered) with those of a host of poor marginalized characters (who are pushed to the periphery). Soderbergh's Contagion is another excellent demonstration of this issue. As elaborated upon in Chapter 3, the contribution of non-Western characters within the film can either be seen as passive or negative. Despite the disease apparently taking root in East Asia, the only significant Chinese contribution to the film is one of deception and underhand behavior. Sun Feng, a Chinese government official, decides to kidnap a white Western epidemiologist working for the WHO as a bargaining chip, with the realization that the distribution of the eventual vaccines produced would not be equitably divided. Although the elderly and the children of the village are living in poverty, they are not presented as "deserving" of help —instead perhaps only "deserving punishment" as symbols of duplicity or dishonesty. Indeed, in order to rescue Dr. Orantes, the Western negotiating team even provides the Chinese captors with a fake vaccine. A key 


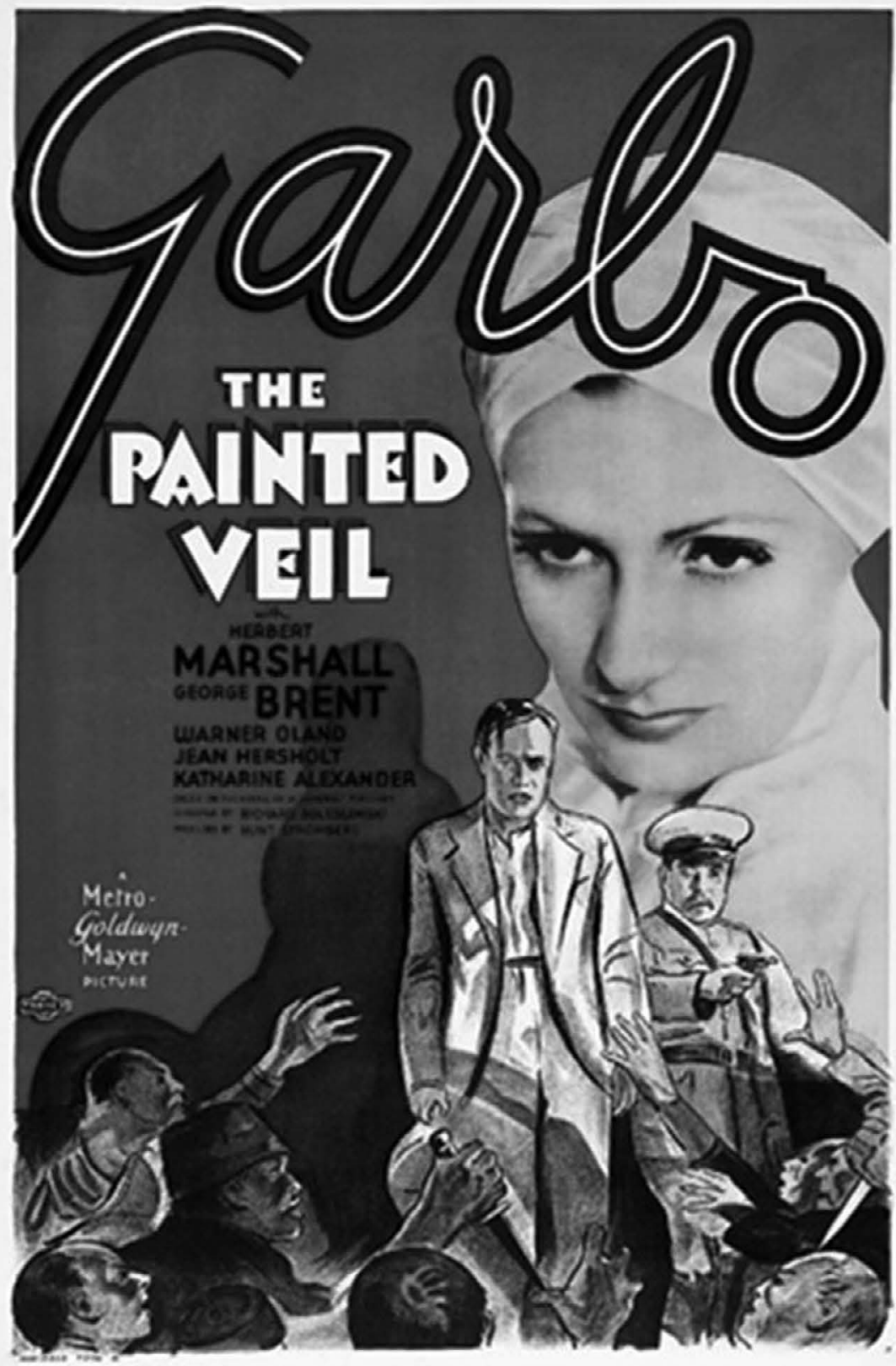

Figure 6.7 Original poster for The Painted Veil (Richard Boleslawski, 1934)

Source: https://en.wikipedia.org/wiki/The_Painted_Veil_(1934_film)\#/media/File:Poster_-_Painted_ Veil,_The_01_Crisco_restoration.jpg [Public domain]. 
component of this paternalistic discourse - entrenched within a wide variety of films - is that the poor cannot simply "demand" aid or to fundamentally question the "rules of the game".

This situation should be juxtaposed against other similarly poor characters within the film. A janitor, Roger (John Hawkes), working at the CDC is also a character with reduced financial means and his own family struggles. In an initial conversion with Dr. Ellis Cheever, we learn that he has a son who has some educational issues and may have ADHD, and accordingly, Dr. Cheever promises Roger that although he has no specific expertise, he could find another doctor who could help him. Probably, this remains an unfulfilled promise, since later, when Roger overhears Dr. Cheever passing on privileged information to his wife to evacuate, Roger is disgusted-iterating the fact that everyone (even a poor janitor, he seems to be saying) has loved ones. In the end, this provides the context behind Dr. Cheever's final act of personal moral redemption - giving up his own vaccine and instead giving it to Roger's young boy instead, who had drawn a lottery date towards the end of the vaccination list. Although poor, here we learn that this white working-class Western family are "deserving" of restorative justice, and "deserving" of the audience's sympathy for their plight.

\section{Conclusion}

Across the course of Chapter 6, we have shown that although poverty, underdevelopment, and epidemic disease have been inextricably linked to one another within a long cinematic history, their association has never been straightforward or static over time. The contradictions have appeared down three major lines. First, we have shown a blurred line between sympathetic and patronizing images produced within cinema, and logically connected, a blurred line between seeing the poor as the main victims of epidemic diseases, and a moralizing view on the actions and decisions of the poor as the likely origins of any outbreak. Occasionally compassion and blame are present in equal measure, or cannot be separated from one another. Second, we have shown how cinema exploits this connection between disease and poverty by making use of its capacity to capture environments - although again this leading to a number of paradoxical positions. Within the rural landscapes portrayed on screen, we see idyllic and unspoiled environments - "unsullied" by forces of capitalism and globalization-isolating themselves from the threat of disease (likely brought by "outsiders"). And yet this stands in opposition to other rural scenes depicted on screen, where rural backwardness and squalor act as not only a vector for disease spread, but ignorance and reactionary qualities lead to the rejection of outside intervention. Accordingly, we link up explicitly with the arguments made in Chapter 2, where social groups presented within film use the epidemic to push back against enforced changes.

In certain films, the "modern" urban environment is presented as under threat or vulnerable to seeds of infection from the "underdeveloped" and impoverished 
countryside - the classic Wald "outbreak narrative" (2008) in practice-however, increasingly from the 1980s onward, film critique moved towards cities as focus points themselves. Here it is not so much the actions of poor people as the potential vectors for disease transmission and spread, but instead, the perilous and precarious position of the poor in conditions of ever-increasing inequality that becomes the symbol or the metaphor for epidemic outbreaks. And finally, although this book has put forward the argument that epidemics visualized within cinema show lines of cohesion and trust seen horizontally among communities, while diminishing trust down hierarchical or vertical lines, we also note that modern classic epidemic-related films such as Contagion remind us that even within conditions of poverty and socio-economic deprivation - there are those on the inside and "deserving" of audience sympathy, while others are left on the periphery or the margins of the narrative, excluded from audience attention. This case is an excellent example of intersectionality in practice, and how major inequalities and vulnerabilities magnified in the depiction of societal responses to epidemics cannot merely be addressed by looking at categories such as "race", "ethnicity", "gender", and "socio-economic status" in isolation, but only make sense when seen as interacting with one another.

\section{Notes}

1 The disparaging view of rural mountain and highland dwellers has long temporal roots and has existed across diverse cultures and geographical contexts (Cohn, 1996).

2 Although in the 1923 version, the plague is brought into the city in the first instance by a beleaguered soldier who had stolen cloth garments from deceased "German" soldiers (in the context of the Thirty Years' War) - staggering through the gates at night and collapsing on the floor (see Figure 6.2).

3 Choi Eun-hee was a South Korean actor who was abducted to North Korea in 1978 and forced to make films until securing asylum at a United States embassy in Vienna in 1986 - one year after the release of Salt (Schönherr, 2012: 75-82).

4 Except for the previously mentioned Youth with the female lead played by Joan Chen in an early role.

5 This sentiment does not merely apply to the "Red Cinema" of the Maoist period, but also the uneasy combination of feudal or conservative critique and nostalgic longing for the "pure" or "original" could easily be applied to the more critically revered cinema of the Fifth Generation filmmakers of the 1980s and 1990s such as Chen Kaige, Tian Zhuangzhuang, Wu Tianming, and Zhang Yimou, as well as the classic films of the 1930s such as Twin Sisters (Zheng Zhengqiu, 1933), The Goddess (Wu Yonggang, 1934), Street Angel (Yuan Muzhi, 1937), Peach Blossom Weeps Tears of Blood (Bu Wancang, 1931), Small Toys (Sun Yu, 1933), The Big Road (Sun Yu, 1933), Fisherman's Song (Cai Chusheng, 1934), and Song of China (Fei Mu, 1935).

6 Although not dealing explicitly with disease, White Zombie (Victor Halperin, 1932) widely considered to be the very first ever zombie film - already linked the issues together (Wonser and Boyns, 2016: 630-631). The zombies here are cursed plantation workers condemned to mindless work for sugar cane factories - thus, with clear references to the legacies of colonial exploitation. Thanks to Daniëlle de Kurver for this reference.

7 In the contemporaneous film Mimic (Guillermo del Toro, 1997), cockroaches again are invoked as spreaders of disease - in this case spreading the fictional "Strickler's Disease" that is particularly debilitating for children. 


\section{References}

Alfani, Guido. "Plague in Seventeenth-Century Europe and the Decline of Italy: An Epidemiological Hypothesis." European Review of Economic History 17, 4 (2013): 408-430.

Anderson, Benedict. Imagined Communities: Reflections on the Origin and Spread of Nationalism. London: Verso, 1983.

Andrews, Julia F. and Kuiyi Shen. The Art of Modern China. Berkeley, CA: University of California Press, 2012.

Anon. "New Sessue Hayakawa Production is Completed for Robertson-Cole." Exhibitors Herald 9, 27 (1919b): 46.

Begin, Paul. "Entomology as Anthropology in the Films of Luis Buñuel." Screen 48, 4 (2007): 425-442.

Bibler, Michael P. "Always the Tragic Jezebel: New Orleans, Katrina, and the Layered Discourse of a Doomed Southern City." Southern Cultures 14, 2 (2008): 6-27.

Boluk, Stephanie and Wylie Lenz. "Infection, Media and Capitalism: From Early Modern Plagues to Postmodern Zombies.” Journal for Early Modern Cultural Studies 10, 2 (2010): 126-147.

Buso, Sandra. "The Nuremburg Laws of the Third Reich and Their Interpretation through the Melodrama of Detlef Sierck/Douglas Sirk's La Habanera (1937)." SandraBuso, August 21, 2018, https://sandrabuso.wordpress.com/2018/08/21/the-nuremburg-lawsof-the-third-reich-and-their-interpretation-through-the-melodrama-of-detlef-sierckdouglas-sirks-la-habanera-1937/.

Chang, Kai-man. "Gender Hierarchy and Environmental Crisis in Tsai Ming-liang's 'The Hole,." Film Criticism 33, 1 (2008): 25-44.

Chung, Steven. "The Split Screen: Sin Sang-ok in North Korea.” In: Sonia Ryang (ed.), North Korea: Toward a Better Understanding, pp. 85-107. Lanham, MD: Lexington Books, 2009.

Chung, Steven. Split Screen Korea: Shin Sang-ok and Postwar Cinema. Minneapolis, MN: University of Minnesota Press, 2014.

Cohn, Samuel Kline. "Inventing Braudel's Mountains: The Florentine Alps after the Black Death.” In: Samuel Kline Cohn and Steven A. Epstein (eds.), Portraits of Medieval and Renaissance Living: Essays in Memory of David Herlihy, pp. 383-416. Ann Arbor, MI: University of Michigan Press, 1996.

Cohn, Samuel Kline. Epidemics: Hate and Compassion from the Plague of Athens to AIDS. Oxford: Oxford University Press, 2018.

Coleclough, Sharon. "Endure, Not Cure: Rammbock and Pandemic Experience." Apparatus: Film, Media and Digital Cultures in Central and Eastern Europe 12 (2021), http:// dx.doi.org/10.17892/app.2021.00012.251.

Conrich, Ian. "An Infected Population: Zombie Culture and the Modern Monstrous." In: Laura Hubner, Marcus Leaning and Paul Manning (eds.), The Zombie Renaissance in Popular Culture, pp. 15-25. New York: Palgrave Macmillan, 2015.

Cooke, Jennifer. Legacies of Plague in Literature, Theory and Film. Basingstoke: Palgrave Macmillan, 2009.

Cowans, Jon. Empire Films and the Crisis of Colonialism, 1946-1959. Baltimore, MD: John Hopkins University Press, 2015.

Cunliffe, Tom. "Lung Kong's Yesterday, Today, Tomorrow: The 1967 Riots and the Politics of Cultural Production in the Hong Kong Film Industry." Screen 61, 1 (2020): 47-74.

De Vito, Anthony J. "Disasters and Disease in the Work of Giovanni Verga." Italica 46, 3 (1969): 279-291. 
Fang, Xiaoping. "Changing Narratives and Persisting Tensions: Conflicts between Chinese and Western Medicine and Professional Profiles in Chinese Films and Literature, 1949-2009." Medical History 63, 4 (2019): 454-474.

Ganjavie, Amir. "Representation of Space/Place in Tsai Ming Liang's The Hole." CrossCultural Communication 8, 3 (2012): 37-45.

Greenfield, Jessica. "Manifestations of Desire in Giovanni Verga's Storia di una Capinera." In: Elena Borelli (ed.), The Fire within: Desire in Modern and Contemporary Italian Literature, pp. 2-17. Cambridge: Cambridge Scholars Publishing, 2014.

Gross, Miriam. 'Between Party, People, and Profession: The Many Faces of the 'Doctor' during the Cultural Revolution." Medical History 62, 3 (2018): 333-359.

Grossman, Julie. "The Trouble with Carol: The Costs of Feeling Good in Todd Hayne's [Safe] and the American Cultural Landscape." Other Voices: The (e)Journal of Cultural Criticism 2, 3 (2005), www.othervoices.org/2.3/jgrossman/\#7b.

Halliday, Jon. "Notes on Sirk's German Films.” Screen 12, 2 (1971): 8-14.

Halper, Thomas and Douglas Muzzio. "Menace II Society? Urban Poverty and Underclass Narratives in American Movies." European Journal of American Studies 8, 1 (2013): $1-31$.

Han, Qijun. "Projecting Chinese Rural Society in Films: The Past and the Present." Cultural and Social History (2021), early online.

Herrick, Clare. "Geographic Charisma and the Potential Energy of Ebola." Sociology of Health and Illness 41, 8 (2019): 1488-1502.

Höglund, Johan. "Eat the Rich: Pandemic Horror Cinema." Transtext(e)s, Transcultures: Journal of Global Cultural Studies 12 (2017), https://doi.org/10.4000/transtexts.706.

Iranzo, Ivan Pintor. "Silence and Fog: On Gesture, Time, and Historicity in the Films of Aleksandr Sokurov." Apparatus: Film, Media and Digital Cultures in Central and Eastern Europe 5 (2017), http://dx.doi.org/10.17892/app.2016.0005.60.

Johnson, Tina Phillips and Yi-Li Wu. "Maternal and Child Health in Nineteenth- to Twenty-First-Century China." In: Bridie Andrews and Mary Brown Bullock (eds.), Medical Transitions in Twentieth-Century China, pp. 51-68. Bloomington, IN: Indiana University Press, 2014.

Knight, Diana. “"Except when Night Falls': Together and Alone in Barthes's Comment vivre ensemble." Paragraph: A Journal of Modern Critical Theory 31, 1 (2008): 50-60.

Lee, David E. "A Flash of Enlightenment: A Brechtian Moment in Douglas Sirk's La Habanera." Monatshefte 100, 3 (2008): 400-414.

McFarlane, Cameron and Ann-Barbara Graff. "Between Two Worlds: The Rains Came and Disaster." Film and History: An Interdisciplinary Journal 42, 2 (2012): 38-54.

McKibben, Ross. "Politics and the Medical Hero: A.J. Cronin's The Citadel." English Historical Review 123, 502 (2008): 651-678.

Mora, Carl. J. Mexican Cinema: Reflections of a Society, 1896-2004, 3rd ed. Jefferson, NC: McFarland \& Co, 2012 [2005].

Naismith, Gaye. "Tales from the Crypt: Contamination and Quarantine in Todd Haynes's [Safe]." In: Paula A. Treichler, Lisa Cartwright and Constance Penley (eds.), The Visible Woman: Imagine Technologies, Gender and Science, pp. 360-387. New York: New York University Press, 1998.

Nollen, Scott Allen and Yuyun Yuningsih Nollen. Chester Morris: His Life and Career. Jefferson, NC: McFarland \& Company, 2020.

Pang, Laikwan. "The Visual Representations of the Barefoot Doctor: Between Medical Policy and Political Struggles.” Positions: Asia Critique 22, 4 (2014): 809-836. 
Pelling, Margaret. "The Meaning of Contagion: Reproduction, Medicine and Metaphor." In: Alison Bashford and Claire Hooker (eds.), Contagion: Historical and Cultural Studies, pp. 15-38. London: Routledge, 2001.

Pernick, Martin S. "Thomas Edison's Tuberculosis Films: Mass Media and Health Propaganda." The Hastings Center Report 8, 3 (1978): 21-27.

Pickowicz, Paul G. "Zheng Junli, Complicity and the Cultural History of Socialist China, 1949-1976." The China Quarterly 188 (2006): 1048-1069.

Posner, Miriam. "Communicating Disease: Tuberculosis, Narrative, and Social Order in Thomas Edison's Red Cross Seal Films." In: Devin Orgeron, Marsha Orgeron and Dan Streible (eds.), Learning with the Lights Off: Educational Film in the United States, pp. 99-106. New York: Oxford University Press, 2012.

Qin, Liyan. "The Intertwinement of Chinese Film and Literature: Choices and Strategies in Adaptations.” In: Yingjin Zhang (ed.), A Companion to Chinese Cinema, pp. 361-377. Chichester: Blackwell, 2012.

Rees, Ellen. "Dreaming of the Medieval in 'Kristin Lavransdatter' and 'Trollsyn'." Scandinavian Studies 75, 3 (2003): 399-416.

Rentschler, Eric. The Ministry of Illusion: Nazi Cinema and its Afterlife. Cambridge, MA: Harvard University Press, 1996.

Rocco, Alessandro. Gabriel García Márquez and the Cinema: Life and Works. Woodbridge: Tamesis, 2014.

Romano, Serena. Moralising Poverty: The 'Undeserving'Poor in the Public Gaze. Abingdon: Routledge, 2017.

Schama, Simon. The Embarrassment of Riches: An Interpretation of Dutch Culture in the Golden Age. Berkeley, CA: University of California Press, 1988.

Scharf, Inga. Nation and Identity in the New German Cinema: Homeless at Home. Routledge: New York, 2008.

Schönherr, Johannes. North Korean Cinema: A History. Jefferson, NC: McFarland \& Company, 2012.

Schulte-Sasse, Linda. "Douglas Sirk's Schlußakkord and the Question of Aesthetic Resistance." The Germanic Review 73, 1 (1998): 2-31.

Seymour, Nicole. “'It's Just Not Turning Up': Cinematic Vision and Environmental Justice in Todd Haynes's 'Safe'." Cinema Journal 50, 4 (2011): 26-47.

Sontag, Susan. Illness as Metaphor. New York: Doubleday, 1978.

Souch, Irina. "Community, Myth, and Metaphor in Pavel Kostomarov's Outbreak Thriller Series Epidemiia/To the Lake (2019)." Apparatus: Film, Media and Digital Cultures in Central and Eastern Europe 12 (2021), http://dx.doi.org/10.17892/app.2021.00012.252.

Squatriti, Paolo. "Marshes and Mentalities in Late Antique and Early Medieval Ravenna." Viator 23 (1992): 1-16.

Steene, Birgitta. "The Sjöberg-Bergman Connection: Hets-Collaboration and Public Impact." TijdSchrift voor Skandinavistiek 20, 1 (1999): 85-101.

Tworek, Heidi J. S. "Communicable Disease: Information, Health, and Globalization in the Interwar Period.” American Historical Review 124, 3 (2019): 813-842.

Wald, Priscilla. Contagious: Cultures, Carriers, and the Outbreak Narrative. Durham, NC: Duke University Press, 2008.

Williams, Raymond. The Country and the City. New York: Oxford University Press, 1973. Wonser, Robert and David Boyns. "Between the Living and Undead: How Zombie Cinema Reflects the Social Construction of Risk, the Anxious Self, and Disease Pandemic.” The Sociological Quarterly 57, 4 (2016): 628-653. 


\section{Urban depravity and rural backwardness}

Yan Du, Daisy. "Socialist Modernity in the Wasteland: Changing Representations of the Female Tractor Driver in China, 1949-1964." Modern Chinese Literature and Culture 29, 1 (2017): 55-94.

Zaniello, Tom. The Cinema of the Precariat: The Exploited, Underemployed, and Temp Workers of the World. London: Bloomsbury, 2020.

Zhang, Yingjin. The City in Modern Chinese Literature and Film: Configurations of Space, Time, and Gender. Stanford, CA: Stanford University Press, 1996. 


\section{Conclusion}

\section{Epidemics and cinema in an age of COVID-19}

Across the course of this book, we have developed an interpretive framework for understanding the depiction of societal responses to epidemic disease outbreaks in cinematic history, and where socially differential vulnerabilities have been foregrounded. In our view, epidemics have long been presented in film as forming a point of cohesion for the communities portrayed, as individuals and groups "from below" as characters in these films find solidarity in a common enemy comprising of elite institutions and authority figures. However, we also pose the question: "cohesion for whom"? Indeed, not all social groups and individuals are included within this expression of collective action and solidarity. Some end up demarcated from the wider community as the marginalized other, and some figures in these films - such as medics with expertise, for example - appear on the blurred boundaries of cohesion and marginalization: part revered as "heroes" defying the establishments, bureaucracies, and administrations, part unrecognized, and part despised as elites or "outsider meddlers" who are simply unreceptive to local cultural contexts and traditional or customary practices.

In this conclusion, we think it is only appropriate to assess our cinematic narrative in line with what has been seen across the world at large from the emergence and spread of COVID-19. How do the stories, ideas, and messages in the history of epidemic-related cinema relate to societies' very recent or ongoing struggle with this disease? Are there similarities in societal responses-life mirroring entrenched values in art and culture to a certain extent - or are there great departures in the way this global pandemic has played out so far (and if so, why)?

It should be noted that one of the dominant frameworks for understanding how societies have dealt with epidemics - especially in the distant past and in modern history-is through the Foucauldian narrative of top-down repressive forces exerting supervision and control (sometimes even physical) on a relatively passive or submissive population (although this has never been complete, and is changing: Curtis, 2020). Our analysis of how cinema has portrayed society-epidemic interactions, however, suggests that this form of visual culture - from the earliest silent films to educational or moralizing documentaries to the feature films that we are well acquainted with today - has tended to more frequently foreground resistance to this application of power. Indeed, many of the characters and protagonists within the cinematic representation of societal responses to epidemics 
are far from docile, passive, and compliant (McGuire, 2021: 4). Although elements of top-down repression and arbitrary action can be seen in some films, one of the most important recurring findings we see through cinematic history is that "ordinary" populations are rarely depicted as submitting easily to these controls. In fact, films written and produced across a wide variety of political and cultural contexts - from Europe, to Latin America, to East Asia - have shown images of passive and active resistance to authorities. Epidemics are visualized on screen as a way of citizens from below-those seemingly without or having restricted power - to start to question the decisions and actions taken by those from aboveinstitutions, elites, and authorities, and the arbitrary or injudicious application of power. This can be in the strong form of physical rejection of impositions, but also within certain filmmaking contexts, can be a moderate form of dialogue or inquiry posed towards authorities (given the overarching political context of film production) - the 1963 Polish film Zaraza is the perfect example.

When we look to how this same narrative has played out around the world during COVID-19, although there may be some anomalies - such as the situation seen in China (perhaps also reinforced by China's effective response to the crisis in certain, but not all, respects) - much of what we have seen around the world is not always a case of governments and authorities using the epidemic to gain further control over the lives of their citizens, and if attempted, certainly not effectively or in a comprehensive and straightforward manner. Instead, the epidemic has been instrumentalized by ordinary citizens - mobilizing themselves to register discontent not only about the nature of the public health responses themselves (which in many cases have been sub-optimal), but also has foregrounded more structural problems already pre-existing within societies that have now come even more prominently to the surface. In that way, the disease has brought many societies face-to-face with concerns ranging from economic inequalities, gender inequalities, inadequacies in social care provision for the elderly and the vulnerable, the spread of disinformation, the overreliance on global production chains, entrenched and institutionalized racism, precarity and the culture of temporary employment contracts, popularizing forms of nationalism and xenophobia, governmental corruption, police brutality and incompetence, and insidious ongoing and future problems related to climate and environment. COVID-19, to a certain extent, strengthened (some) bonds established horizontally, while reducing the trust that ordinary populations had in their vertical or hierarchical institutions. Accordingly, there are a lot of parallels with the situations we have identified to cinematic representation of epidemic outbreaks. To us, that reveals the continued relevance of cinema - even in an age of diversified entertainment options.

A second facet that we should foreground is the similar prominence of Orientalization within visual culture and within contemporary societal responses to COVID-19. Films have long dwelt on fears of China as a locus for disease outbreaks - something which has continued and perhaps even magnified in recent years with the likes of Contagion. Indeed, just like the veiled two-sided critique of developments in China put forward in Soderbergh's 2011 picture, COVID-19 
from its early emergence in world consciousness was established as a "Chinese phenomenon". Notwithstanding some of the crasser forms of Sinophobia leading to prejudice, discrimination, and violence against people of East Asian descent around the world, ${ }^{1}$ a two-sided moralizing narrative was also formed (Hilkens et al., 2020). On the one hand, this moral judgment scrutinized a society down the lines of degeneration, lack of hygiene, and insalubriousness - with special scrutiny for the concept of the "wet market" (Lynteris, 2016b) — and parallels to the chaotic seafood market scenes portrayed in Contagion. The narratives of "lab leaks" and "wet markets" were established around an apparent need for the "smoking gun" of certainty about modes of transmission - and films have for a long time perpetuated that same narrative with their presentation of clearly prescribed "hero", "villain", and "traitor" roles. Overall, this side of the story pointed to classic elements of "underdevelopment" - the kinds of Western anxieties that are fundamental components of the "outbreak narrative" developed by Wald (2008). Yet on the other hand, this moral judgment curiously went in the other direction by scrutinizing tendencies towards Chinese "over-development" - incorporating Western fears about economic development and modernization occurring "unchecked" at a ferocious pace - and again reflected in scenes in Contagion towards the end of the film where natural environments are being encroached upon by human settlements and developers. According to Lynteris (2018a: 52), this kind of two-sided narrative presented a "liminal state" where old practices and new practices collide, and in turn, is seen as responsible for the kinds of environmental and societal vulnerabilities that allow a newly emerging virus to proliferate.

A third clear parallel between what has been visualized on the cinema screen and that which has emerged during our experiences of COVID-19 is the close association between the representation of women and epidemics in film, discussed in Chapter 5, and the experiences of women during this global pandemic. Although we wait to observe the long-term structural gendered effects of COVID19 , the immediate and short-term impact has been widely (in both wealthy and poorer countries) reported as harsher for women - from precarity of employment to burdened care provision roles to vulnerabilities to domestic abuse to disruption to access to sexual and reproductive health services (Wenham et al., 2020a, 2020 b). It is remarkable then that in a long cinematic history - but also something still existing within modern twenty-first-century films - we see the same perpetuation of gendered epidemic images such as the "burdened and self-sacrificing woman" and perhaps even more worryingly the "female spreader" image. Disease in cinema has, and continues to be, instrumentalized by directors - even if this is done in an unthinking or subconscious way - to tell a message that women straying outside prescribed traditional roles are likely to cause a terrible affliction leading to the suffering of the wider community. This entrenched element of even contemporary cinema in the West should lead us to reflect on the fact that while notions such as women obeying men or putting up with violence is commonly derided as "wrong" or "bad" in wealthy democracies of Western Europe and North America, it easy to forget that this change in thinking is historically fairly recent and still highly incomplete. 
If those are the major similarities between societal responses to epidemics captured on film and societal responses seen in the first year of the world's interaction with COVID-19, then are there also any points of divergence? From our analysis, one of the major aspects seems to be the celebration of the ordinary citizenperhaps even the concept of the "ordinary hero" elaborated upon in Chapter 4 even if this development in itself is not entirely straightforward. Although we have placed developments from below as one of the key features of cinematic representation of societal responses to epidemic disease outbreaks, we should also note that usually this is in resistance - either active or passive - to the decisions and actions made by authorities, which are usually framed as arbitrary or excessive or simply ineffectual. In film, the saviors have and still remain elite or authority figures - with their main role being to convince skeptical communities or act in spite of resistance, or as with the case of the elite medics, change their behavior and attitudes to come closer to "ordinary society". During COVID-19, however, we have seen this kind of development move one step further with an explicit recognition and even celebration of the efforts of the ordinary citizen - using their skills and dedication to make a difference during a crisis, while under excessive pressures. While government officials continue to be scrutinized, workers in a variety of sectors from education, health, social care, and food production have been lauded for their efforts. Although perhaps naïve and over-optimistic, we can only hope that this is one lasting egalitarian consequence of COVID-19 not (yet) reflected in cinematic history that outlasts and outlives this global pandemic.

\section{Note}

1 A comprehensive list can be found at https://en.wikipedia.org/wiki/List_of_incidents_of_ xenophobia_and_racism_related_to_the_COVID-19_pandemic [accessed $\overline{15 / 10 / 2020}$ ].

\section{References}

Curtis, Daniel R. "Preserving the Ordinary: Social Resistance during Second Pandemic Plagues in the Low Countries." In: Christopher Gerrard, Paolo Forlin and Peter Brown (eds.), Waiting for the Ends of the World: Perceptions of Disaster and Risk in Medieval Europe, vol. 43, pp. 280-297. London: Routledge, 2020.

Hilkens, Bram, Bram van Besouw and Daniel R. Curtis. "A Modern Rendition of a PreModern Scenario: Imperfect Institutions and Obscured Vulnerabilities." Journal for the History of Environment and Society 5 (2020): 211-221.

Lynteris, Christos. "The Prophetic Faculty of Epidemic Photography: Chinese Wet Markets and the Imagination of the Next Pandemic." Visual Anthropology 29, 2 (2016b): 118-132.

Lynteris, Christos. "Yellow Peril Epidemics: The Political Ontology of Degeneration and Emergence." In: Frank Billé and Soren Urbansky (eds.), Yellow Perils: China Narratives in the Contemporary World, pp. 35-59. Honolulu, HI: Hawaii University Press, 2018a.

McGuire, Kelly. "COVID-19, Contagion, and Vaccine Optimism." Journal of Medical Humanities 42, 1 (2021): 51-62.

Wald, Priscilla. Contagious: Cultures, Carriers, and the Outbreak Narrative. Durham, NC: Duke University Press, 2008. 
Wenham, Clare, João Nunes, Gustavo Correa Matta, Carolina de Oliveira Nogueira, Polyana Aparecida Valente and Denise Nacif Pimenta. "Gender Mainstreaming as a Pathway for Sustainable Arbovirus Control in Latin America." PLoS Neglected Tropical Diseases 14, 2 (2020b): e0007954.

Wenham, Clare, Julia Smith and Rosemary Morgan. "COVID-19: The Gendered Impacts of the Outbreak." The Lancet 395, 10277 (2020a): 846-884. 


\section{Appendix}

\section{Filmography of films depicting epidemics ${ }^{1}$}

\begin{tabular}{|c|c|c|c|c|c|}
\hline Film & International title & Year & Country & Director & Disease \\
\hline The Red Cross Seal & & 1910 & USA & Charles J. Brabin & Tuberculosis \\
\hline The Awakening of John Bond & & 1911 & USA & Oscar Apfel/Charles J. Brabin & Tuberculosis \\
\hline Hope: A Red Cross Seal Story & & 1912 & USA & Charles J. Brabin & Tuberculosis \\
\hline The Price of Human Lives & & 1913 & USA & Richard Ridgely & Tuberculosis \\
\hline The Temple of Moloch & & 1914 & USA & Langdon West & Tuberculosis \\
\hline The Lone Game & & 1915 & USA & Edward C. Taylor & Tuberculosis \\
\hline The Beggar of Cawnpore & & 1916 & USA & Charles Swickard & Cholera \\
\hline Storia di una capinera & & 1917 & Italy & Giuseppe Sterni & Cholera \\
\hline A Man's Country & & 1919 & USA & Henry Kolker & Plague \\
\hline Dr. Wise on Influenza & & 1919 & UK & Joseph Best & Influenza \\
\hline The End of the Road & & 1919 & USA & Edward H. Griffith & Syphilis \\
\hline Open Your Eyes & & 1919 & USA & Gilbert P. Hamilton & Syphilis \\
\hline The Man Beneath & & 1919 & USA & William Worthington & Plague \\
\hline Die Pest in Florenz & The Plague of Florence & 1919 & Germany & Otto Rippert & Plague \\
\hline Insaeng ŭi ku: hoyŏlja & Life's Enemy: Cholera & 1920 & Korea & Kim Sorang & Cholera \\
\hline Häxan & $\begin{array}{l}\text { Witchcraft Through the } \\
\text { Ages }\end{array}$ & 1922 & Sweden/Denmark & Benjamin Christensen & Plague \\
\hline $\begin{array}{l}\text { Nosferatu, eine Symphonie des } \\
\text { Grauens }\end{array}$ & $\begin{array}{l}\text { Nosferatu: A Symphony } \\
\text { of Horror }\end{array}$ & 1922 & Germany & Friedrich Wilhelm Murnau & Plague \\
\hline 预防霍乱 [Yufang huoluan] & Preventing Cholera & 1922 & Taiwan & Anon. & Cholera \\
\hline I promessi sposi & The Betrothed & 1923 & Italy & Mario Bonnard & Plague \\
\hline How Disease Is Spread & & 1924 & USA & US, PHS & Tuberculosis \\
\hline 傳染病の病原體 & Infectious Bacteria & 1925 & Japan & Japan, MoE & Bacterial diseases \\
\hline
\end{tabular}




\begin{tabular}{|c|c|c|c|c|c|}
\hline 蚊の一生と疾病の傳播 & $\begin{array}{l}\text { The Life of a Mosquito } \\
\text { and the Spread of } \\
\text { Disease }\end{array}$ & 1925 & Japan & Japan, MoE & Malaria \\
\hline 蠅とその害毒 & Flies and Diseases & 1926 & Japan & Japan, MoE & Various \\
\hline $\begin{array}{l}\text { 病毒の伝播 [Byodoku no } \\
\text { denpa] }\end{array}$ & Diseases Spread & 1926 & Japan & Sanae Yamamoto & Various \\
\hline The Blonde Saint & & 1926 & USA & Svend Gade & Cholera \\
\hline Arrowsmith & & 1931 & USA & John Ford & Plague \\
\hline Rain & & 1932 & USA & Lewis Milestone & Cholera \\
\hline Doctor Bull & & 1933 & USA & John Ford & Typhoid fever \\
\hline Las hurdes: Tierra sin pan & Land Without Bread & 1933 & Spain & Luis Buñuel & Dysentery \\
\hline One Man's Journey & & 1933 & USA & John S. Robertson & Smallpox \\
\hline 結核豫防 & $\begin{array}{l}\text { Preventing } \\
\quad \text { Tuberculosis }\end{array}$ & 1933 & Japan & Japan, PHD & Tuberculosis \\
\hline The Painted Veil & & 1934 & USA & Richard Boleslawski & Cholera \\
\hline Green Light & & 1937 & USA & Frank Borzage & $\begin{array}{l}\text { Rocky Mountain sp. } \\
\text { fever }\end{array}$ \\
\hline Bílá nemoc & Skeleton on Horseback & 1937 & Czechoslovakia & Hugo Haas & The White Plague (F) \\
\hline La Habanera & & 1937 & Germany & Douglas Sirk & Puerto Rico fever (F) \\
\hline The Empty Bed & & 1937 & UK & King Brown/Guy Bousfield & Diphtheria \\
\hline The Citadel & & 1938 & UK & King Vidor & Tuberculosis \\
\hline Jezebel & & 1938 & USA & William Wyler & Yellow fever \\
\hline A Man to Remember & & 1938 & USA & Garson Kanin & Polio \\
\hline Yellow Jack & & 1938 & USA & George B. Seitz & Yellow fever \\
\hline Pacific Liner & & 1939 & USA & Lew Landers & Cholera \\
\hline The Rains Came & & 1939 & USA & Clarence Brown & Cholera \\
\hline Let My People Live & & 1939 & USA & Edgar G. Ulmer & Tuberculosis \\
\hline
\end{tabular}




\begin{tabular}{|c|c|c|c|c|c|}
\hline Film & International title & Year & Country & Director & Disease \\
\hline On the Firing Line & & 1939 & USA & National Tuberculosis Assoc. & Tuberculosis \\
\hline Dr. Ehrlich's Magic Bullet & & 1940 & USA & William Dieterle & Tuberculosis/syphilis \\
\hline Two Brothers & & 1940 & South Africa & & Syphilis \\
\hline They Do Come Back & & 1940 & USA & Edgar G. Ulmer & Tuberculosis \\
\hline I promessi sposi & The Betrothed & 1941 & Italy & Mario Camerini & Plague \\
\hline Fight Syphilis & & 1941 & USA & Owen Murray & Syphilis \\
\hline Feind Malaria & Enemy Malaria & 1942 & Germany & & Malaria \\
\hline Two Families & & 1942 & South Africa & & Tuberculosis \\
\hline Himlaspelet & The Heavenly Play & 1942 & Sweden & Alf Sjöberg & Plague \\
\hline Storia di una capinera & & 1943 & Italy & Gennaro Righelli & Cholera \\
\hline The Winged Scourge & & 1943 & USA & Bill Justice & Malaria \\
\hline You Too Can Get Malaria & & 1944 & UK & Sydney Box & Malaria \\
\hline $\begin{array}{l}\text { Private Snafu vs. Malaria } \\
\text { Mike }\end{array}$ & & 1944 & USA & Chuck Jones & Malaria \\
\hline Target Snafu & & 1944 & USA & Friz Freleng & Malaria \\
\hline It's Murder She Says & & 1945 & USA & Chuck Jones & Malaria \\
\hline Tsutsugamushi: Prevention & & 1945 & USA & US Navy & Scrub Typhus \\
\hline The Bells of St. Mary's & & 1945 & USA & Leo McCarey & Tuberculosis \\
\hline The Mosquito & & 1945 & USA & US Army Air Forces & Malaria \\
\hline Borne on Two Wings & & 1945 & UK & UK War Office & Malaria \\
\hline DDT Versus Malaria & & 1946 & Kenya & Cyril Garnham & Malaria \\
\hline Sister Kenny & & 1946 & USA & Dudley Nichols/Jack Gage & Polio \\
\hline Seuchengefahr & Epidemic Threat & 1946 & Germany & Hans Cürlis/Fritz Dick & $\begin{array}{l}\text { Dysentery; Typhoid } \\
\text { Fever }\end{array}$ \\
\hline Fleckfieber droht & $\begin{array}{l}\text { Threat of Spotted } \\
\text { Fever }\end{array}$ & 1946 & Germany & Hans Cürlis/Fritz Dick & Typhus \\
\hline Monsieur Vincent & & 1947 & France & Maurice Cloche & Plague \\
\hline Driftwood & & 1947 & USA & Allan Dwan & $\begin{array}{l}\text { Rocky Mountain sp. } \\
\text { fever }\end{array}$ \\
\hline
\end{tabular}


Counterblast

The Eternal Fight

Sins of the Fathers

Yu fang shuyi

Singoalla

The Sardinian Project

静かなる決闘[Shizukanaru kettō]

Panic on the Streets

Rodney

Defeat Tuberculosis

The Killer That Stalked New York

The Life Cycle of the Malaria Parasite

Surprise Attack

The Whip Hand

Les Orgueilleux

Saadia

Outbreak

The Command

The Elephant Walk

Medical Officer of Health

They Rode West

The Invisible Enemy

The Rains of Ranchipur

The Seventh Sin

Det sjunde inseglet

Неповторимая весна

[Nepovtorimaya vesna]
1948 UK

1948 USA

1948 Canada

1948 China

Prevention of Plague

1949 Sweden/France

1949 UK

1949 Japan

1950 USA

1950 USA

1950 UK

1950 USA

1951 UK

1951 UK

1951 USA

The Proud and the Beautiful

1953 France/Mexico

1953 USA

1953 UK

1954 USA

1954 USA

1954 UK

1954 USA

1955 UK

1955 USA

1957 USA

1957 Sweden

The Seventh Seal

A Unique Spring
Paul L. Stein

Victor Vicas

Richard J. Jarvis/Phil Rosen

Northeast Film Studio

Christian-Jaque

J.D. Chambers

Akira Kurosawa

Elia Kazan

Lu Guarnier

UK, MoI

Earl McEvoy

H.E. Short

UK, Crown Film Unit

William Cameron Menzies

Yves Allégret

Albert Lewin

Anon.

David Butler

William Dieterle

Robert Barr

Phil Karlson

WHO

Jean Negulesco

Ronald Neame

Ingmar Bergman

Aleksandr Stolper
Bacterial disease (F)

Various diseases

Syphilis

Plague

Plague

Malaria

Syphilis

Pneumonic plague

Tuberculosis

Tuberculosis

Smallpox

Malaria

Smallpox

Poisoned water $(\mathrm{F})$

Meningitis

Plague

Foot \& Mouth Disease

Smallpox

Cholera

Smallpox

Malaria

General pathogens

Cholera

Cholera

Plague

Plague 


\begin{tabular}{|c|c|c|c|c|c|}
\hline Film & International title & Year & Country & Director & Disease \\
\hline Space Master X-7 & & 1958 & USA & Edward Bernds & Fungus infection $(\mathrm{F})$ \\
\hline The Man Who Wouldn't Talk & & 1958 & UK & Herbert Wilcox & Virus (F) \\
\hline The Nun's Story & & 1959 & USA & Fred Zinnemann & Tuberculosis \\
\hline The Tingler & & 1959 & USA & William Castle & Parasite (F) \\
\hline Beyond the Time Barrier & & 1960 & USA & Edgar G. Ulmer & "Cosmic plague" (F) \\
\hline Suspect/The Risk & & 1960 & UK & John Boulting/Ray Boulting & Plague \\
\hline Dance, Little Children & & 1961 & USA & Herk Harvey & Syphilis \\
\hline A Matter of $W H O$ & & 1961 & UK & Don Chaffey & Smallpox \\
\hline 枯木逢春 [Kumu fengchun] & $\begin{array}{l}\text { Spring Comes to the } \\
\text { Withered Tree }\end{array}$ & 1961 & China & Zheng Junli & Schistosomiasis \\
\hline The Spiral Tree & & 1962 & USA & Robert Mulligan & Leprosy \\
\hline America America & The Anatolian Smile & 1963 & USA & Elia Kazan & Tuberculosis \\
\hline 80,000 Suspects & & 1963 & UK & Val Guest & Smallpox \\
\hline The Masque of the Red Death & & 1964 & USA & Roger Corman & Red Death $(F)$ \\
\hline コレラの城 [Korera no shiro] & $\begin{array}{l}\text { The Treasure of Death } \\
\text { Castle }\end{array}$ & 1964 & Japan & Tetsuro Tanba & Cholera \\
\hline I promessi sposi & The Betrothed & 1964 & Italy & Mario Maffei & Plague \\
\hline The Last Man on Earth & & 1964 & USA & $\begin{array}{l}\text { Ubaldo Ragona/Sidney } \\
\text { Salkow }\end{array}$ & Vampire infection $(\mathrm{F})$ \\
\hline The Satan Bug & & 1965 & USA & John Sturges & The Satan Bug (F) \\
\hline 7 Women & & 1966 & USA & John Ford & Cholera \\
\hline $\begin{array}{l}\text { B город пришла беда }[V \\
\quad \text { gorod prishla beda }]\end{array}$ & & 1966 & Soviet Union & Mark Orlov & Smallpox \\
\hline The Plague of the Zombies & & 1966 & UK & John Gilling & Zombie infection $(\mathrm{F})$ \\
\hline L'armata brancaleone & For Love and Gold & 1966 & Italy & Mario Monicelli & Plague \\
\hline Tarzan and the Great River & & 1967 & USA & Robert Day & Undetermined $(\mathrm{F})$ \\
\hline $\begin{array}{l}\text { What's So Bad About Feeling } \\
\text { Good? }\end{array}$ & & 1968 & USA & George Seaton & “Niceness" virus (F) \\
\hline Карантин [Karantin] & Quarantine & 1968 & Soviet Union & Sulamif Tsybulnik & Laboratory virus (F) \\
\hline
\end{tabular}


Night of the Living Dead

On Her Majesty's Secret

$$
\text { Service }
$$

昨天今天明天 [Zuotian

jintian mingtian]

Morte a Venezia

The Devils

The Last Valley

The Andromeda Strain

The Omega Man

Komitet 19-ti

Vampire Circus

Zaraza

The Pied Piper

The Satanic Rites of Dracula

The Crazies

Bram Stoker's Dracula

Mariken van Nieumeghen

春苗 [Chun miao]

红雨 $[$ Hong yu]

Monty Python and the Holy

$$
\text { Grail }
$$

Winterhawk

The Ultimate Warrior

Léonor

Shivers

Der Fangschuß

雁鸣湖畔 [Yanming hupan]

The Cassandra Crossing

Rabid

青春 [Qingchun]
1968 USA

1969 UK/USA

Yesterday, Today, Tomorrow

Death in Venice

$\begin{array}{lll} & 1971 & \text { USA } \\ & 1971 & \text { UK/USA } \\ & 1971 & \text { USA } \\ & 1971 & \text { USA } \\ \text { The Committee of 19 } & 1972 & \text { Soviet Union } \\ & 1972 & \text { UK } \\ \text { The Epidemic } & 1972 & \text { Poland } \\ & 1972 & \text { UK } \\ & 1973 & \text { UK } \\ & 1973 & \text { USA } \\ & 1974 & \text { UK } \\ & 1974 & \text { Netherlands } \\ & 1975 & \text { China } \\ & 1975 & \text { China } \\ \text { Spring Shoots } & 1975 & \text { UK } \\ \text { Red Rain } & & \\ & 1975 & \text { USA } \\ & 1975 & \text { USA } \\ & 1975 & \text { Spain/France/Italy } \\ & 1975 & \text { USA } \\ \text { Mistress of the Devil } & 1976 & \text { Germany } \\ & 1976 & \text { China } \\ \text { Coup de Grace } & 1976 & \text { Italy/UK/Germany } \\ \text { By the Yanming Lake } & 1977 & \text { USA } \\ & 1977 & \text { China }\end{array}$

George A. Romero

Peter R. Hunt

Patrick Lung Kong

Luchino Visconti

Ken Russell

James Clavell

Robert Wise

Boris Sagal

Savva Kulish

Robert Young

Roman Zaluski

Jacques Demy

Alan Gibson

George A. Romero

Dan Curtis

Jos Stelling

Xie Jin

Cui Wei

Terry Gilliam/Terry Jones

Charles B. Pierce

Robert Clouse

Juan Luis Buñuel

David Cronenberg

Volker Schlöndorff

Gao Tianhong

George Pan Cosmatos

David Cronenberg

Xie Jin
Zombie infection (F)

Bacterial agent (F)

Plague

Cholera

Plague

Plague

Andromeda (F)

Mutant-infection (F)

Various

Fictional plague (F)

Smallpox

Plague

Fictional plague $(\mathrm{F})$

Trixie virus (F)

Fictional plague (F)

Plague

Various

Various

Plague

Smallpox

Undefined pandemic (F)

Plague

STD, Parasite (F)

Typhus

Various

Pneumonic plague

Rabies (F)

Various 


\begin{tabular}{l}
\hline Film \\
\hline Dawn of the Dead \\
The Alpha Incident \\
Plague \\
Nosferatu: Phantom der Nacht \\
Die Hamburger Krankheit \\
El año de la peste \\
Cristo si è fermato a Eboli \\
復活の日 [Fukkatsu no hi] \\
Gaijin-Caminhos da \\
liberdade \\
Variola vera \\
The Plague Dogs \\
Fanny Crosby \\
Day of the Dead \\
神医扁鹊 [Shen yi bian que] \\
An Early Frost \\
소금 \\
Warning Sign \\
Buddies \\
1918 \\
Flesh+Blood \\
Al-yawm al-Sadis \\
盜马贼 $[$ Daoma zei] \\
Parting Glances \\
The Secret Garden \\
Intimate Contact \\
Epidemic
\end{tabular}

$\begin{array}{lll}\text { International title } & \text { Year } & \text { Country } \\ & 1978 & \text { USA } \\ 1978 & \text { USA } \\ & 1979 & \text { Canada/USA } \\ & 1979 & \text { Germany/France } \\ \text { Nosferatu the Vampyre } & 1979 & \text { Germany/France } \\ \text { The Hamburg } & & \\ \text { Syndrome } & 1979 & \text { Mexico } \\ \text { The Year of the Plague } & 1979 & \text { Italy/France } \\ \text { Christ Stopped at Eboli } & 1980 & \text { Japan } \\ \text { Virus/Day of } & & \\ \text { Resurrection } & 1980 & \text { Brazil } \\ \text { Gaijin-Roads to } & & \\ \text { Freedom } & 1982 & \text { Yugoslavia } \\ & 1982 & \text { UK } \\ & 1984 & \text { USA } \\ & 1985 & \text { USA } \\ & 1985 & \text { China } \\ & 1985 & \text { USA } \\ & 1985 & \text { North Korea } \\ \text { Salt } & 1985 & \text { USA } \\ & 1985 & \text { USA } \\ & 1985 & \text { USA } \\ & 1985 & \text { USA/Netherlands } \\ \text { The Sixth Day } & 1986 & \text { Egypt } \\ \text { The Horse Thief } & 1986 & \text { China } \\ & 1986 & \text { USA } \\ & 1987 & \text { USA } \\ & 1987 & \text { UK } \\ & 1987 & \text { Denmark } \\ & & \end{array}$

Director Disease

George A. Romero

Bill Rebane

Ed Hunt

Werner Herzog

Peter Fleischmann

Felipe Cazals

Francesco Rosi

Kinji Fukasaku

Tizuka Yamasaki

Goran Markovic

Martin Rosen

Ken Anderson

George A. Romero

Yin Cui

John Erman

Shin Sang-ok

Hal Barwood

Arthur J. Bressan Jr.

Ken Harrison

Paul Verhoeven

Youssef Chahine

Tian Zhuangzhuang

Bill Sherwood

Alan Grint

Waris Hussein

Lars von Trier
Zombie infection (F)

Microorganism (F)

M3 bacteria $(\mathrm{F})$

Fictional plague (F)

Mysterious illness (F)

Fictional plague (F)

Various diseases

MM88 virus (F)

Malaria

Smallpox

Plague

Cholera

Zombie infection (F)

Various

HIV/AIDS

Undefined virus

Bacterial infection $(F)$

HIV/AIDS

Influenza

Plague

Cholera

Epizootic

HIV/AIDS

Cholera

HIV/AIDS

Fictional plague (F) 
黑太阳731 [Hei taiyang 731]

The Navigator: A Medieval Odyssey

Дни затмения $[\mathrm{Dni}$ zatmenija ]

Encore

Common Threads: Stories

from the Quilt

The Sleep of Death

Entebbe Encounter

Tongues Untied

The Ryan White Story

The Masque of the Red Death

Longtime Companion

Awakenings

At Play in the Fields of the

$$
\text { Lord }
$$

La Peste

Citizen Cohn

Quiet Killer

אלפומ דסח [Hessed mufla]

Bram Stoker's Dracula

Les Nuits Fauves

Seasons of the Heart

Zero Patience

Blue

Storia di una capinera

The Hour of the Pig

Philadelphia

Carnosaur

戏梦人生 [Ximeng rensheng]
Men Behind the Sun

Days of Eclipse

Once More

The Plague
Amazing Grace
Savage Nights
Sparrow
The Puppetmaster

1988 Hong Kong

1988 Australia/N. Zealand Vincent Ward

Aleksandr Sokurov

Paul Vecchiali

Rob Epstein/Jeffrey Friedman

Mark Brackenbury

Anthony Palmer

Marlon T. Riggs

John Herzfeld

Larry Brand/Jeffrey Delman

Norman René

Penny Marshall

Héctor Babenco

1992 Argentina/France/UK

1992 USA

1992 USA

1992 Israel

1992 USA

1992 France

1993 USA

1993 Canada

1993 UK

1993 Italy

1993 UK/France

1993 USA

1993 USA

1993 Taiwan
Luis Puenzo

Frank Pierson

Sheldon Larry

Amos Guttman

Francis Ford Coppola

Cyril Collard

T.C. Christensen

John Greyson

Derek Jarman

Franco Zeffirelli

Leslie Megahey

Jonathan Demme

Adam Simon

Hou Hsiao-hsien
Plague

Plague

Various

HIV/AIDS

HIV/AIDS

Sleeping Sickness

Sleeping Sickness

HIV/AIDS

HIV/AIDS

Red Death (F)

HIV/AIDS

Sleeping Sickness

Blackwater fever

Plague

HIV/AIDS

Plague

HIV/AIDS

Fictional plague (F)

HIV/AIDS

Cholera

HIV/AIDS

HIV/AIDS

Cholera

Plague

HIV/AIDS

Virus (F)

Malaria 


\begin{tabular}{|c|c|c|c|c|c|}
\hline Film & International title & Year & Country & Director & Disease \\
\hline $\begin{array}{l}\text { Silverlake Life: The View from } \\
\text { Here }\end{array}$ & & 1993 & USA & Peter Friedman/Tom Joslin & HIV/AIDS \\
\hline And the Band Played On & & 1993 & USA & Roger Spottiswoode & HIV/AIDS \\
\hline Trollsyn & Second Sight & 1994 & Norway & Ola Solum & Plague \\
\hline Outbreak & & 1995 & USA & Wolfgang Petersen & Motaba virus $(\mathrm{F})$ \\
\hline Jeffrey & & 1995 & USA & Christopher Ashley & HIV/AIDS \\
\hline Boys on the Side & & 1995 & USA & Herbert Ross & HIV/AIDS \\
\hline Kids & & 1995 & USA & Larry Clark & HIV/AIDS \\
\hline Safe & & 1995 & USA & Todd Haynes & $\begin{array}{l}\text { Mult. chem. sensitivity } \\
\text { (F) }\end{array}$ \\
\hline Virus & & 1995 & USA & Armand Mastroianni & Virus (F) \\
\hline The Cure & & 1995 & USA & Peter Horton & HIV/AIDS \\
\hline Le Hussard sur le toit & $\begin{array}{l}\text { The Horseman on the } \\
\text { Roof }\end{array}$ & 1995 & France & Jean-Paul Rappeneau & Cholera \\
\hline Restoration & & 1995 & USA & Michael Hoffman & Plague \\
\hline 12 Monkeys & & 1995 & USA & Terry Gilliam & Virus (F) \\
\hline $\begin{array}{l}\text { 伊波拉病毒 [Yi boh lai beng } \\
\quad d u k]\end{array}$ & Ebola Syndrome & 1996 & Hong Kong & Herman Yau & Ebola \\
\hline It's My Party & & 1996 & USA & Randal Kleiser & HIV/AIDS \\
\hline Mimic & & 1997 & USA & Guillermo del Toro & Strickler's disease (F) \\
\hline A River Made to Drown In & & 1997 & USA & $\begin{array}{l}\text { James Merendino/Alan } \\
\text { Smitheenos }\end{array}$ & HIV/AIDS \\
\hline Miss Evers'Boys & & 1997 & USA & Joseph Sargent & Syphilis \\
\hline Contagious & & 1997 & USA/Canada & Joe Napolitano & Cholera \\
\hline Dangerous Beauty & & 1998 & USA & Marshall Herskovitz & Plague \\
\hline 洞 [Dong] & The Hole & 1998 & Taiwan & Tsai Ming-liang & Taiwan Fever (F) \\
\hline Todo sobre mi madre & All About My Mother & 1999 & Spain & Pedro Almódovar & HIV/AIDS \\
\hline Mission Impossible 2 & & 2000 & USA & John Woo & Chimera virus $(\mathrm{F})$ \\
\hline Before Night Falls & & 2000 & USA & Julian Schnabel & HIV/AIDS \\
\hline
\end{tabular}


Runaway Virus

Cabin Fever

Anazapta

The Hours

28 Days Later

Resident Evil

Angels in America

惊心动魄 [Jingxin dongpo]

零下三十八度 [Lingxia

sanshi ba du]

非典人生 [Fei dim yan sang]

金鸡2 [Gam gai 2]

天作之盒 [Tin chok ji hap]

Yesterday

The Libertine

感染 [Kansen]

A Home at the End of the World

Shaun of the Dead

Dawn of the Dead

My Brother . . . Nikki

Un año sin amor

$V$ for Vendetta

エリ・エリ・レア・サ

バクタ二 [Eri Eri rema

sabakutani]

The Constant Gardener

Stormbreaker

Mulberry Street

Fatal Contact: Bird Flu in

America

괴물 [Gwoemul]
2000 USA

2002 USA

2002 UK

2002 USA

2002 UK

2002 Germany/UK

2003 USA

Profoundly Affecting

2003 China

2003 China

2003 Hong Kong

City of SARS

Golden Chicken 2

The Miracle Box

Infection

A Year Without Love
My God, My God, Why
Hast Thou Forsaken
Me?

2004 UK

2004 USA

2005 India

2005 Argentina

2005 UK/Germany/USA

2005 Japan

2005 UK/Germany/USA

2006 UK/Germany/USA

2006 USA

2006 USA

2006 South Korea
Jeff Bleckner

Eli Roth

Alberto Sciamma

Stephen Daldry

Danny Boyle

Paul W.S. Anderson

Mike Nichols

Dong Shen/Jia Wang

Xin Liu

Wai-Man Cheng

Leung Chun "Samson" Chiu

Adrian Kwan

Darrell James Roodt

Laurence Dunmore

Masayuki Ochiai

Michael Mayer

Edgar Wright

Zack Snyder

Onir

Anahí Berneri

James McTeigue

Shinji Aoyama

Fernando Meirelles

Geoffrey Sax

Jim Mickle

Richard Pearce

Bong Joon-ho
Influenza

Necrotizing fasciitis

Plague

HIV/AIDS

Rage-inducing virus (F)

T-Virus (F)

HIV/AIDS

SARS (F: based on)

SARS

SARS

SARS

SARS

HIV/AIDS

Syphilis

Virus (F)

HIV/AIDS

Zombie infection $(\mathrm{F})$

Zombie infection (F)

HIV/AIDS

HIV/AIDS

St. Mary's virus (F)

Suicide disease (F)

Tuberculosis

Smallpox (F)

Rat-borne infection (F)

Avian Influenza

Virus (F) 
Resident Evil: Apocalypse

Children of Men

Ultraviolet

The Painted Veil

Rec

Flight of the Living Dead

28 Weeks Later

Les Témoins

Life Support

Pandemic

Love in the Time of Cholera

Your Friend the Rat

The Invasion

Medieval Pie

I am Legend

Resident Evil: Extinction

The Dead Outside

Quarantine

Pontypool

Repo! The Genetic Opera

Doomsday

Toxic Skies

Sex Positive

Philosophy of a Knife

Blindness

赤壁 [Chibi]

$\begin{array}{lll}\text { International title } & \text { Year } & \text { Country } \\ & 2006 & \text { USA } \\ & 2006 & \text { Germany/UK } \\ 2006 & \text { UK/USA/Japan } \\ 2006 & \text { USA } \\ & 2006 & \text { USA/China } \\ & 2007 & \text { Spain } \\ & 2007 & \text { USA } \\ & 2007 & \text { UK/Spain } \\ & 2007 & \text { France } \\ & 2007 & \text { USA } \\ & 2007 & \text { USA } \\ & 2007 & \text { USA } \\ & 2007 & \text { USA } \\ & 2007 & \text { USA } \\ & 2007 & \text { Italy/UK/France } \\ & 2007 & \text { USA } \\ & 2007 & \text { Germany/UK } \\ & 2008 & \text { UK } \\ & 2008 & \text { USA } \\ & 2008 & \text { Canada } \\ 2008 & \text { USA } \\ 2008 & \text { UK } \\ \text { Red Cliff } & 2008 & \text { Canada } \\ & 2008 & \text { USA } \\ 2008 & \text { Russia } \\ 2008 & \text { Brazil/Canada/Japan } \\ & 2009 & \text { China } \\ & & \end{array}$

Director

Disease

Mel Gibson

Alexander Witt

Alfonso Cuarón

Kurt Wimmer

John Curran

Jaume Balagueró/Paco Plaza

Scott Thomas

Juan Carlos Fresnadillo

André Téchiné

Nelson George

Armand Mastroianni

Mike Newell

Jim Capobianco

Oliver Hirschbiegel

David Leland

Francis Lawrence

Russell Mulcahy

Kerry Anne Mullaney

John Erick Dowdle

Bruce McDonald

Darren Lynn Bousman

Neil Marshall

Andrew C. Erin

Daryl Wein

Andrey Iskanov

Fernando Meirelles

John Woo
Influenza/Smallpox/

Measles

T-Virus (F)

Flu (F)

Hemoglophagia (F)

Cholera

Virus (F)

Zombie virus (F)

Rage-inducing virus $(\mathrm{F})$

HIV/AIDS

HIV/AIDS

Avian Influenza

Cholera

Plague

Behavioral virus $(\mathrm{F})$

Plague

Virus (F)

T-Virus (F)

Neurological disease (F)

Rabies

Speech infection $(\mathrm{F})$

Organ-failure (F)

Reaper virus (F)

Virus (F)

HIV/AIDS

Plague

White sickness (F)

Typhoid fever 
Daybreakers

District 9

$\operatorname{Rec} 2$

Mal'aria

Cabin Fever 2: Spring Fever

Doghouse

Love Takes Wing

Carriers

感染列島 [Kansen rettô]

Resident Evil: Afterlife

The Crazies

Rammbock

The Lazarus Effect

Black Death

在一起 [Zai yiqi]

Fase 7

Season of the Witch

最爱 [Zui ai]

Perfect Sense

Quarantine 2: Terminal

We Were Here

Retreat

Schlafkrankheit

Contagion

Rec 3: Genesis

Resident Evil: Retribution

Shanghai Strangers

The Sessions

연가시 [Yeon-ga-si]

逆战 [Ni zhan]

How to Survive a Plague
2009 Australia/USA

2009 S. Africa/USA/NZ

2009 Spain

2009 Italy

2009 USA

2009 UK

2009 USA

2009 USA

2009 Japan

2010 Germany/UK

2010 USA

2010 Germany

2010 USA

Together

Phase 7

Love for Life

2010 Germany/UK

2010 China

2010 Argentina

2011 USA

2011 China

2011 UK/Denmark/Ireland

2011 USA

2011 USA

2011 UK

Sleeping Sickness 2011 Germany

2011 USA

2012 Spain

2012 Germany/UK

2012 China

2012 USA

Deranged

The Viral Factor
2012 South Korea

2012 China/Hong Kong

2012 USA
Michael Spierig/Peter Spierig

Neill Blomkamp

Jaume Balagueró/Paco Plaza

Paolo Bianchini

Ti West

Jake West

Lou Diamond Phillips

Alex Pastor/David Pastor

Takahisa Zeze

Paul W.S. Anderson

Breck Eisner

Marvin Kren

Lance Bangs

Christopher Smith

Zhao Liang

Nicolás Goldbart

Dominic Sena

Gu Changwei

David Mackenzie

John Pogue

David Weissman

Carl Tibbetts

Ulrich Köhler

Steven Soderbergh

Paco Plaza

Paul W.S. Anderson

Joan Chen

Ben Lewin

Jeong-woo Park

Dante Lam

David France
Vampire infection $(\mathrm{F})$

Infection (F)

Virus (F)

Malaria

Necrotizing fasciitis

Cannibal Infection (F)

Unknown ailment (F)

Virus (F)

Virus (F)

T-Virus (F)

Trixie virus $(\mathrm{F})$

Zombie infection $(\mathrm{F})$

HIV/AIDS

Plague

HIV/AIDS

Respiratory disease $(\mathrm{F})$

Plague

HIV/AIDS

Loss of senses $(\mathrm{F})$

Rabies

HIV/AIDS

Argromoto Flu (F)

Sleeping Sickness

MEV-1 virus (F)

Virus (F)

T-Virus (F)

SARS

Polio

Yeongasi (F)

Smallpox (F)

HIV/AIDS 


\begin{tabular}{|c|c|c|c|c|c|}
\hline Film & International title & Year & Country & Director & Disease \\
\hline En kongelig affcere & A Royal Affair & 2012 & Denmark/Sweden & Nikolaj Arcel & Smallpox \\
\hline The Bay & & 2012 & USA & Barry Levinson & Water-borne parasite $(\mathrm{F})$ \\
\hline $\begin{array}{l}\text { United in Anger: A History of } \\
\quad A C T \text { UP }\end{array}$ & & 2012 & USA & Jim Hubbard & HIV/AIDS \\
\hline Dallas Buyers Club & & 2013 & USA & Jean-Marc Vallée & HIV/AIDS \\
\hline Der Medicus & The Physician & 2013 & Germany & Philipp Stölzl & Plague \\
\hline $\begin{array}{l}\text { 厨子·戏子・㾙子 [Chuzi xizi } \\
\quad \text { pizi] }\end{array}$ & $\begin{array}{l}\text { The Chef, The Actor, } \\
\text { The Scoundrel }\end{array}$ & 2013 & China & Guan $\mathrm{Hu}$ & Cholera \\
\hline 大明劫 [Daming jie $]$ & Fall of Ming & 2013 & China & Wang Jing & Shuyi (plague) \\
\hline 감기 [Gamgi] & Flu & 2013 & South Korea & Kim Sung-su & H5N1 influenza virus \\
\hline Fire in the Blood & & 2013 & India & Dylan Mohan Gray & HIV/AIDS \\
\hline World War Z & & 2013 & USA & Marc Forster & Zombie plague $(\mathrm{F})$ \\
\hline Cólera & Cholera & 2013 & Spain & Aritz Moreno & Cholera \\
\hline Antisocial & & 2013 & Canada & Cody Calahan & Virus (F) \\
\hline The Returned & & 2013 & Spain/Canada & Manuel Carballo & Zombie infection $(\mathrm{F})$ \\
\hline Contracted & & 2013 & USA & Eric England & Necrotic STD (F) \\
\hline Los últimos días & The Last Days & 2013 & Spain & David Pastor/Alex Pastor & Fear of open spaces $(\mathrm{F})$ \\
\hline Cabin Fever 3: Patient Zero & & 2014 & USA & Kaare Andrews & Necrotizing fasciitis \\
\hline The Normal Heart & & 2014 & USA & Ryan Murphy & HIV/AIDS \\
\hline $\begin{array}{l}\text { Dawn of the Planet of the } \\
\text { Apes }\end{array}$ & & 2014 & USA & Matt Reeves & Simian Flu (F) \\
\hline 黄金时代 [Huangjin shidai] & The Golden Era & 2014 & Hong Kong & Ann Hui & $\begin{array}{l}\text { Cholera/plague/ } \\
\text { tuberculosis }\end{array}$ \\
\hline Rec 4: Apocalypse & & 2014 & Spain & Jaume Balagueró & Virus (F) \\
\hline Scent & & 2014 & USA & The Existentialist & $\begin{array}{l}\text { Airborne, madness/ } \\
\text { lust }(\mathrm{F})\end{array}$ \\
\hline Holding the Man & & 2015 & Australia & Neil Armfield & HIV/AIDS \\
\hline Ebola Zombies & & 2015 & Hong Kong & Samuel Leong & Ebola \\
\hline
\end{tabular}


Antisocial 2

Contracted: Phase II

Maggie

Last Ones Out

Embers

Rams

Toxin: 700 Days Left on Earth

Equals

Extinction

부산행 [Busanhaeng]

Viral

The Girl with All the Gifts

Cabin Fever

The 5th Wave

Resident Evil: The Final Chapter

Inferno

Here Alone

Chuma v aule Karatas

Pandemic

93 Days

Breathe

It Comes at Night

Epidemie svobody

Pili

120 BPM

The Cured

战狼2 [Zhan lang II]

Mudbound
Train to Busan

2015 Canada

2015 USA

2015 USA

2015 South Africa

2015 Spain

2015 Iceland

2015 USA

2015 USA

2015 Spain/France/

2016 South Korea

2016 USA

2016 UK

2016 USA

2016 USA

2016 Germany/UK

2016 USA

2016 USA

The Plague at the

2016 Kazakhstan

Karatas Village

2016 USA

2016 Nigeria

2017 USA/UK

2017 USA

An Epidemic of

Freedom

2017 Czech Republic

2017 UK/Tanzania

2017 France

2017 Ireland

Wolf Warrior 2
2017 China

2017 USA
Cody Calahan

Josh Forbes

Henry Hobson

Howard Fyvie

Claire Carré

Grímur Hákonarson

Shawn Welling

Drake Doremus

Miguel Ángel Vivas

Sang-ho Yeon

Henry Joost/Ariel Schulman

Colm McCarthy

Travis $\mathrm{Z}$

J Blakeson

Paul W.S. Anderson

Ron Howard

Rod Blackhurst

Adilkhan Yerzhanov

John Suits

Steve Gukas

Andy Serkis

Trey Edward Shults

Tereza Reichová/Hynek Štětka

Leanne Welham

Robin Campillo

David Freyne

Wu Jing

Dee Rees
Redroom virus (F)

Necrotic STD (F)

Zombie infection (F)

Zombie infection (F)

Neurological epidemic (F)

Scrapie

Virus (F)

Emotion-eraser (F)

Zombie virus (F)

Zombie virus $(\mathrm{F})$

Virus (F)

Fungus infection (F)

Necrotizing fasciitis

Avian flu (F)

T-Virus (F)

Inferno virus (F)

Zombie infection $(\mathrm{F})$

Mysterious flu (F)

Virus (F)

Ebola

Polio

Virus (F)

Various

\section{HIV/AIDS}

HIV/AIDS

Maze Virus (F)

Lamanla (F)

Whooping cough 
Isle of Dogs

Jai mat tse moon

Bohemian Rhapsody

Li Shan

Plaire, aimer et courir vite Sorry Angel

Patient Zero

1985

Odessa

Infección

Virus

Light of my Life

Only

Posljednji Srbin u Hrvatskoj

Rabid

The Directive

\#살아있다 [Saraitda]

Strasbourg 1518

Putham pudhu Kaalai

Alone

Corona Zombies

Songbird

Totally Under Control

Corona: Fear is a Virus

Coronation

The Leakers

Infection Croatia

Alive
The Last Serb in

A Brand New Dawn

$\begin{array}{ll}2018 & \text { USA/Germany } \\ 2018 & \text { Hong Kong/Malays } \\ 2018 & \text { USA/UK } \\ 2018 & \text { USA } \\ 2018 & \text { France } \\ 2018 & \text { USA/UK } \\ 2018 & \text { USA } \\ 2019 & \text { Russia } \\ 2019 & \text { Venezuela/Mexico } \\ 2019 & \text { India } \\ 2019 & \text { USA } \\ 2019 & \text { USA } \\ 2019 & \text { Croatia } \\ 2019 & \text { USA } \\ 2019 & \text { USA } \\ 2020 & \text { S. Korea } \\ 2020 & \text { UK } \\ 2020 & \text { India } \\ 2020 & \text { USA } \\ 2020 & \text { USA } \\ 2020 & \text { USA } \\ 2020 & \text { USA } \\ 2020 & \text { Canada } \\ 2020 & \text { UK }\end{array}$

Director

Disease

Ben Howling/Yolanda Ramke Rabid virus (F)

Jennifer Yuh Nelson

Wes Anderson

Herman Yau

Bryan Singer

Wenqi You

Christophe Honoré

Stefan Ruzowitzky

Yen Tan

V. Todorovskiy/I. Tretyakova

Flavio Pedota

Aashiq Abu

Casey Affleck

Takashi Doscher

Predrag Licina

Jen Soska/Sylvia Soska

Alexander Pimentel

Cho Il-hyung

Jonathan Glazer

Sudha Kongara (and others)

Johnny Martin

Charles Band

Adam Mason

Alex Gibney (and others)

Mostafa Keshvari

Ai Weiwei
Idiopathic

Adolescent Acute

Neurodegeneration (F)

Canine Flu (F)

Zika (mutation)

HIV/AIDS

SARS

HIV/AIDS

Rabies-like (F)

HIV/AIDS

Cholera

Rabies

Nipah virus

Virus (F)

Virus (for women) (F)

Zombie infection (F)

Rabies

Virus (F)

Zombie infection $(\mathrm{F})$

Dancing Mania

COVID-19

Zombie infection $(\mathrm{F})$

COVID-19

COVID-19

COVID-19

COVID-19

COVID-19 
76 Days

Greetings from Isolation

Host

Rams

Homemade

Locked Down

Safer at Home

Help

Note

1 Documentary-education films are included in this filmography as long as they have a narrative element to them (i.e., an educational film but using a story and characters). In the "disease" column, the marker "HIV/AIDS" is used as a term of convenience (within restricted space) to describe a film that deals with HIV and/or AIDS rather than an implicit assumption that contraction of HIV inevitably leads to AIDS. Plague refers to the disease caused by bacterial pathogen Yersinia pestis, whilst Fictional plague refers to a film that describes a "plague" in general terms, but does not actually have any similarity in modes of transmission or epidemiological features to an actual plague. MoE refers to Ministry of Education; PHS refers to Public Health Service; PHD refers to Public Health Division; MoI refers to Ministry of Information; MoH refers to Ministry of Health.

$\begin{array}{ll}\text { Weixi Chen/Hao Wu } & \text { COVID-19 } \\ \text { Various } & \text { COVID-19 } \\ \text { Rob Savage } & \text { COVID-19 } \\ \text { Jeremy Sims } & \text { Ovine Johne's Disease } \\ \text { Various } & \text { COVID-19 } \\ \text { Doug Liman } & \text { COVID-19 } \\ \text { Will Wernick } & \text { COVID-19 } \\ \text { Jack Thorne } & \text { COVID-19 }\end{array}$

COVID-19
Weixi Chen/Hao Wu

$\begin{array}{ll}2020 & \text { USA/China } \\ 2020 & \text { Canada } \\ 2020 & \text { UK } \\ 2020 & \text { Australia } \\ 2020 & \text { Chile/Italy } \\ 2021 & \text { USA } \\ 2021 & \text { USA } \\ 2021 & \text { UK }\end{array}$




\section{Index}

affairs see infidelity

Africa 4-6, 9, 34-37, 42, 49, 67-68, 72, 85,115

AIDS 13, 17-18, 27-28, 34, 37, 43, 49, 153

aliens 17

amah 55, 86

animal 36, 93, 103, 114

Australia 101-102

bacteriologist $36,41,55-57,62,70$, $73-74,77,81,125$

barefoot doctors 16, 118-119

Barthes, Roland 112

bat $16,36,59$

Beck, Ulrich 34, 49, 69

Bergman, Ingmar 31-33, 90, 115

biopower 10-12, 48

bioterrorism $5,16,27,100$

Black Death 30-34, 53, 88, 90-92, 98, 102, 114

boat see ship

Boccaccio, Giovanni 30

Bombay 110

British 18, 29-31, 35-41, 55-56, 67, 73, 79-81, 90-93, 97-98, 100, 109-111, 115,121

Buñuel, Luis 81, 114

Butler, Judith 50

Calcutta 110

Camus, Albert 31-33, 43, 54

Cannes 4, 88, 122

capitalism 12, 18, 32, 108, 120, 128

Catholic 55-58, 75, 97, 102

CDC 1, 5, 8, 59-61, 70, 77, 127

Chang, Grace 123-124

Chen, Joan 128

Chicago 59-60
China 4, 9, 12-16, 19, 32-37, 40-42, 52, 55-64, 72-75, 94, 97, 111, 116-119, $121,125-126,128,134-135$

Chinatowns 52

Chinese see China

cholera 9, 14, 28-32, 35-43, 48, 55-58, 73-75, 90, 95-97, 109-113

church 9, 53, 87, 95

cockroaches 102, 122, 128

coffin 111

Cold War 15-17

colonial 9, 31-32, 36-42, 49, 56-57, 63, $85,97,109-111,121-122,128$

communist 15,32

Coppola, Francis Ford 100

Coronavirus see COVID-19

COVID-19 1-7, 12, 19, 34-38, 43, 50, 52, 60-63, 67-70, 76, 80-81, 85, 133-136

Cronenberg, David 17-18, 93

Cultural Revolution 118

curfews 1

deserving poor $11,124-127$

devil 88, 90, 115

Disney 14

distrust 48-66

domestic abuse 135

Dracula 20, 100

Dutch 42, 89, 108

earthquake 7, 48, 54, 85, 97

Eastern Europe 16, 71

Ebola 4-6, 34-36, 48-49, 67-68, 72, 85, 94, 115-116

elites $2-3,10-12,16,28,32,37-43$, 48-52, 56-63, 70-73, 76-81, 97, 108-111, 133-136

epidemiologists 11, 36, 59-61, 70-71, 77, $80-81,94,97,101,125$ 
factory $34,109,114$

famines $54,60,110,116,118$

farmer 59, 103, 116

fascist 31,67

female tractor driver 119

feudal $9,32,58,128$

fever 9, 14, 36-37, 40, 75-76, 79, 99, $102,110,113-114$

flu $1,4,6,31,35,41,59-61,72,94$, 96,107

Flynn, Errol 79, 113

Foucauldian see Foucault, Michel

Foucault, Michel 10, 38, 48, 52, 133

funerals $48,85,87$

Garbo, Greta 55, 125

German 29-30, 42, 73, 93, 110, 113, 120, 128

germ theory 55, 73, 109

globalization 1, 11, 18, 34, 127

Great Leap Forward 32, 118

Hayakawa, Sessue 110

hazmat 2, 67

heroes $67-84,101-102$

Herzog, Werner 17

HIV see AIDS

Hollywood 8, 93, 111

Hong Kong 32, 40, 59-63, 121-123

horror $16-17,27,37,63,100,114,120$

hygiene $36,51,58,68,90,135$

\section{Ibn Sina 93}

IMDB 4, 12, 50, 63

immigration 15, 109

immorality $27-47$

India $34,38,80,97,109-111$

inequality $1,4,7,18,85,122,128$

infidelity $53-56,59-62,92,96$

influenza see flu

James Bond series 16

Japan 3, 9, 12, 14, 32, 51-53, 75-76, 90, $110,114,116$

key workers $67-68$

knight 28, 32, 36, 70, 73, 90, 93, 112, 115

Kolkata see Calcutta

Korea 9, 14, 19, 32, 41, 90, 93-94, 96, 107, 116-117, 128

laboratory $16,39,55-56,61,77-78,94$, 109,115

laborers 9, 34, 107-110, 120
Lagos 115

London 39, 55-56, 59, 95, 115, 120

Macau 36, 59-60, 92-93

malaria 14-15, 91, 98-99, 113-114

Malleus Maleficarum 32

Mallon, Mary 87-88

Manchuria 9

Mann, Thomas 29, 112

Manzoni, Alessandro 32, 116

Mao Zedong 9, 118, 128

Maugham, W. Somerset 55, 73

May Thirtieth Movement 56, 73

medics 2, 5, 8-9, 11, 16-17, 30, 37-42, $67-84$

medieval 30-33, 43, 87, 93, 98, 102, 115

Meirelles, Fernando 10, 18, 51, 80

melodrama 14, 109-110

Mexico 30, 39, 78

miasma 43, 55, 73, 87

Middle Ages see medieval

Middle East 6, 35, 41

Milan 35, 116

missionaries 9, 55-56, 97-98

mistrust 5-6, 27, 60

Moloch 14, 34, 109

Monty Python 31, 90

Moral Panic 6, 27, 49

Moscow 16, 113

mosquito 16, 75-76, 91-92, 99

MRSA 68

Mumbai see Bombay

Mussolini, Benito 32

nationalism 68,134

Nazi 15,110

Netflix 4, 19

New York 15, 27-32, 71, 87-88, 92, 113

NHS 68-69

Nobel Prize 39

Noffie 91-92

Nollywood 116

ordinary hero $12,69-70,76-77,80-81$, 136

Orientalized 35-36, 52, 56, 134

orphan $32,55,58,93,96$

outbreak narrative $6-10,19,28,34-36,48$, $86,92,107,116,128,135$

Palme d'Or 29, 122

pathogen $2-3,16,36,52,61,63,67,115$

peasant $31,87,98,114-119,125$

pig $30,36,59,90,115$ 
plague $4-5,9,14-20,27-43,52-53,58$, $63,67,71,75,78,85-90,93,96-102$, 108-112, 115-118, 121-122, 128, 153

Poland 16, 40, 71, 134

polio $8,76,101$

Pope 88

prejudice $6,10,18,27-28,34,50,54,63$, $85,87,135$

priest 32,101

protests $1,38,56$

psychology 4, 12, 27-28, 68

Puerto Rico 110

quarantine $4,16,29,40-43,48-49,55,62$, $73,99,107,112,116$

rabies 93

racist $3,14,19,43$

rape $30,51-55,92,98,116,125$

rats $17,20,34$

Red Cinema 128

religious $32,35,41,79,87,97$

riots $1,31,121$

Rockefeller Institute 110

Romania 4

Romero, George A. 17, 28, 71, 120

Russell, Ken 32

Russia 16, 42, 58, 113, 125

San Francisco 111

Saramago, José 51, 54

SARS 7, 9, 34, 41, 59

scapegoats $28,31,36,87,113$

schistosomiasis 16, 32, 117-118

Second World War 14-15, 29, 39, 67, 71, $76,78,90-92,98,101,111-112$ sexuality $3,34,49,86-87,93,100$ sex workers $37,79,85,91$

Shanghai $35,55-56,73,111,118$

ship 20, 35, 107, 111-112

Sicily 95,113

smallpox 15-16, 29, 35, 38, 71, 79, 90-92

small-town America 112

social media 5, 69
Soderbergh, Steven 4, 8, 59, 73, 125, 134

Sontag, Susan 18, 27, 34, 120

South Africa 9

South America 9, 18, 35

Southern Italy 113-114

Soviet Union see Russia

Spain 81,114

stigma $6,27,33,87$

Sweden 32

Taiwan 1, 9, 14, 40, 102, 122

Third Plague Pandemic 52

Tian Zhuangzhuang 18, 128

Trier, Lars von 18, 28-29

tuberculosis 8-9, 14-16, 19, 34-35, 39, 43, $76,79,90,109,112,115$

typhoid 14, 76, 87-88, 107

urbanization 109

vaccination 5-6, 16, 29, 48, 59-61, 68-70, 76-79, 90, 125-127

vampires $17,20,34,62,100$

Venice 29, 31

Verga, Giovanni 95, 113

Verhoeven, Paul 30, 102

Versailles 56

Villani, Giovanni 30

violence $10,19,27,37-38,41,53,56-58$, $85,95-97,102,117,125,135$

vulnerability $1-7,11,36-37,43,49-51$, $63,77-78,81,85-87,92,98,102,107$, $115,127-128,133-135$

warlord 58-59, 64, 75, 97-98

Wikipedia 5, 43, 126, 136

Winslet, Kate 61

witch 31, 37, 87-90, 102

xenophobia 43, 68, 134-136

yellow fever 9, 14, 37, 75-76, 99

zombie 4-5, 13, 18-20, 27-29, 72, 75, 93, $96,100,120,128$ 